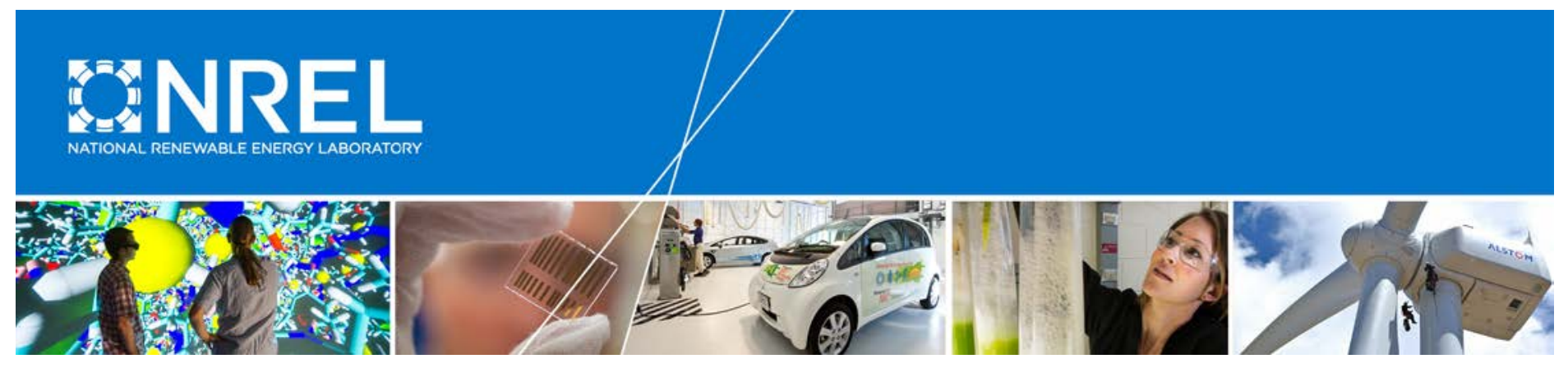

\title{
High-Efficiency Housing at the Fort Peck Indian Reservation: Opportunities and Lessons Learned
}

Lars Lisell, Jesse Dean, and Jal Desai National Renewable Energy Laboratory

Tim Rehder

U.S. Environmental Protection Agency, Region 8

NREL is a national laboratory of the U.S. Department of Energy Office of Energy Efficiency \& Renewable Energy Operated by the Alliance for Sustainable Energy, LLC

This report is available at no cost from the National Renewable Energy Laboratory (NREL) at www.nrel.gov/publications.

Technical Report

NREL/TP-7A40-70617

March 2018

Contract No. DE-AC36-08G028308 


\section{High-Efficiency Housing at the Fort Peck Indian Reservation: Opportunities and Lessons Learned}

Lars Lisell, Jesse Dean, and Jal Desai National Renewable Energy Laboratory

Tim Rehder

U.S. Environmental Protection Agency, Region 8

NREL is a national laboratory of the U.S. Department of Energy Office of Energy Efficiency \& Renewable Energy Operated by the Alliance for Sustainable Energy, LLC

This report is available at no cost from the National Renewable Energy Laboratory (NREL) at www.nrel.gov/publications.

National Renewable Energy Laboratory 15013 Denver West Parkway Golden, CO 80401

303-275-3000 • www.nrel.gov

\section{Technical Report}

NREL/TP-7A40-70617

March 2018

Contract No. DE-AC36-08GO28308 


\section{NOTICE}

This report was prepared as an account of work sponsored by an agency of the United States government. Neither the United States government nor any agency thereof, nor any of their employees, makes any warranty, express or implied, or assumes any legal liability or responsibility for the accuracy, completeness, or usefulness of any information, apparatus, product, or process disclosed, or represents that its use would not infringe privately owned rights. Reference herein to any specific commercial product, process, or service by trade name, trademark, manufacturer, or otherwise does not necessarily constitute or imply its endorsement, recommendation, or favoring by the United States government or any agency thereof. The views and opinions of authors expressed herein do not necessarily state or reflect those of the United States government or any agency thereof.

This report is available at no cost from the National Renewable Energy Laboratory (NREL) at www.nrel.gov/publications.

Available electronically at SciTech Connect http:/www.osti.gov/scitech

Available for a processing fee to U.S. Department of Energy and its contractors, in paper, from:

U.S. Department of Energy

Office of Scientific and Technical Information

P.O. Box 62

Oak Ridge, TN 37831-0062

OSTI http://www.osti.gov

Phone: 865.576.8401

Fax: 865.576.5728

Email: reports@osti.gov

Available for sale to the public, in paper, from:

U.S. Department of Commerce

National Technical Information Service

5301 Shawnee Road

Alexandria, VA 22312

NTIS http://www.ntis.gov

Phone: 800.553 .6847 or 703.605 .6000

Fax: 703.605.6900

Email: orders@ntis.gov 


\section{Acknowledgments}

The authors of the report would like to acknowledge the U.S. Environmental Protection Agency Region 8 office for supporting this work, and all the effort by Tim Rehder, Tony Zimmer, and Diana Hammer. The work was supplemented by E3 Power, and the authors are thankful for their expertise and knowledge. The team would like to give a special thanks to the people of the Fort Peck Assiniboine \& Sioux Tribes, as well as Deb Madison and Martina Wilson for enabling successful site visits for the team. 


\section{List of Acronyms}

$\mathrm{ACH}$

AFUE

BEopt ${ }^{\mathrm{TM}}$

CFL

DHW

EF

ERV

ECM

kWh

LED

MIRF

PV

SEER

SHGC

TMY air changes per hour

annual fuel use efficiency

Building Energy Optimization

compact fluorescent lighting

domestic hot water

energy factor

energy recovery ventilator

energy conservation measure

kilowatt-hour

light-emitting diode

Make It Right Foundation

photovoltaics

seasonal energy efficiency ratio

solar heat gain coefficient

typical meteorological year 


\section{Executive Summary}

This project was initiated to provide design assistance in an effort to maximize energy performance for affordable housing at the Fort Peck Indian Reservation near Poplar, Montana. The Make It Right Foundation (MIRF) built 20 high-performing homes (Leadership in Energy and Environmental Design [LEED] Platinum) in 2015 and 2016 with three different design options.

The National Renewable Energy Laboratory and the U.S. Environmental Protection Agency set out to provide energy analysis along with measurement and verification of the homes to characterize energy use and provide clarity for future decision making regarding tribal housing options. The results included herein summarize the energy end uses and document projected energy impacts from various aspects of the MIRF home designs and construction.

This report includes an analysis of energy use in five MIRF homes, comparing energy use across the different styles and configurations. Energy models were created for the two styles of MIRF homes, including renewable energy assessment for photovoltaic (PV) systems. Existing tribal housing was analyzed, with five housing units analyzed for energy use and an energy model created for one housing unit.

The findings of this study highlight many of the challenges that arise when attempting to construct high-performance housing in a region where such construction practices are still relatively rare.

- The homes in Poplar are well designed, for the most part, and include climate-specific design considerations appropriate for northeastern Montana.

- The most significant issues identified in MIRF homes were related to the work done to put the homes on the foundation, insulate the crawlspaces, and make the final connection with the utilities.

- The Taxed II Credit homes are well designed and well suited to northeastern Montana, and, with slight modifications to the design and construction, could be very efficient.

- All occupant comfort and energy use issues that were identified during the site visits can be remedied through retrofit measures that are relatively inexpensive.

- Energy-efficiency opportunities were found that can be implemented in each of the homes. These retrofits are generally inexpensive and have a quick return on investment.

- The MIRF homes and the Taxed II Credit homes can achieve high levels of energy performance with modest retrofits. Similar houses built in the future could achieve even better performance with minor design changes and generally low incremental cost.

- Renewable energy systems are economically feasible in this area, but the payback is on the high side of what would likely be acceptable to homeowners. If the price of solar comes down to $\$ 2 /$ watt installed, the systems will achieve a simple payback of 13 years, which is likely a return on investment that is attractive to homeowners.

- If the homes are made sufficiently tight to be high performance, energy recovery ventilators will be necessary to maintain acceptable indoor air quality. The Taxed II 
Credit homes are already equipped with energy recovery ventilators, which seem to function well.

- As PV prices continue to decline, projects should be implemented as they become cost effective.

The following energy-efficiency measures were identified in the existing homes at Fort Peck.

Table ES-1. Option House Energy-Efficient Measures Summary ${ }^{1}$

\begin{tabular}{|c|c|c|c|c|c|}
\hline ECM Title & $\begin{array}{l}\text { Annual } \\
\text { Electricity } \\
\text { Savings } \\
\text { (kWh/yr) }\end{array}$ & $\begin{array}{l}\text { Annual } \\
\text { Natural } \\
\text { Gas } \\
\text { Savings } \\
\text { (therm/yr) }\end{array}$ & $\begin{array}{l}\text { Annual } \\
\text { Cost } \\
\text { Savings } \\
\text { (\$/yr) }\end{array}$ & $\begin{array}{l}\text { Installed } \\
\text { Cost } \\
(\$)\end{array}$ & $\begin{array}{l}\text { Simple } \\
\text { Payback } \\
\text { (yrs) }\end{array}$ \\
\hline $\begin{array}{l}\text { Relocated Water Lines to } \\
\text { Underside of Insulation and } \\
\text { Repair R-38 Crawlspace } \\
\text { Insulation }\end{array}$ & -23 & 35.9 & $\$ 15$ & $\$ 1,600$ & 106.7 \\
\hline $\begin{array}{l}\text { Revise Thermostat to } 72^{\circ} \mathrm{F} \\
\text { Cooling and } 70^{\circ} \mathrm{F} \text { Heating }\end{array}$ & 206 & 162.6 & $\$ 87$ & $\$ 0$ & 0.0 \\
\hline $\begin{array}{l}\text { Reduce Plug Load Energy Use } \\
\text { via Wi-Fi Plug Load Outlet }\end{array}$ & 1,114 & -25.6 & $\$ 63$ & $\$ 120$ & 1.9 \\
\hline $\begin{array}{l}\text { Retrofit LED Interior and Exterior } \\
\text { Lighting }\end{array}$ & 472 & -10.6 & $\$ 27$ & $\$ 140$ & 5.2 \\
\hline Combined & $1,747.0$ & 161.7 & $\$ 192$ & $\$ 1,860$ & 9.7 \\
\hline
\end{tabular}

Table ES-2. Living Home Energy-Efficient Measures Summary

\begin{tabular}{|c|c|c|c|c|c|}
\hline ECM Title & $\begin{array}{l}\text { Annual } \\
\text { Electricity } \\
\text { Savings } \\
\text { (kWh/yr) }\end{array}$ & $\begin{array}{l}\text { Annual } \\
\text { Natural } \\
\text { Gas } \\
\text { Savings } \\
\text { (therm/yr) }\end{array}$ & $\begin{array}{l}\text { Annual } \\
\text { Cost } \\
\text { Savings } \\
(\$ / y r)\end{array}$ & $\begin{array}{l}\text { Installed } \\
\text { Cost } \\
(\$)\end{array}$ & $\begin{array}{l}\text { Simple } \\
\text { Payback } \\
\text { (yrs) }\end{array}$ \\
\hline $\begin{array}{l}\text { Relocated Water Lines to } \\
\text { Underside of Insulation and } \\
\text { Repair R-38 Crawlspace } \\
\text { Insulation }\end{array}$ & -23 & 35.2 & $\$ 21$ & $\$ 1,000$ & 48 \\
\hline Program Thermostats & 1,560 & 77.4 & $\$ 185$ & $\$ 0$ & 0.0 \\
\hline $\begin{array}{l}\text { Reduce Plug Load Energy Use } \\
\text { via Wi-Fi Plug Load Outlet }\end{array}$ & 4,566 & -107.3 & $\$ 323$ & $\$ 240$ & 0.7 \\
\hline $\begin{array}{l}\text { Retrofit LED Interior and Exterior } \\
\text { Lighting }\end{array}$ & 557 & -12.3 & $\$ 40$ & $\$ 140$ & 3.5 \\
\hline Reduce Infiltration in Home & -61 & 215.2 & $\$ 135$ & $\$ 1,500$ & 11.1 \\
\hline Combined & 6,599 & 161.7 & $\$ 703$ & $\$ 2,880$ & 4.1 \\
\hline
\end{tabular}

\footnotetext{
${ }^{1}$ Negative number mean that energy usage increases as a result of the ECM. This typically happens when less electrical energy usage results in more heating fuel requirements.
} 
Table ES-3. Taxed II Credit Homes Energy-Efficient Measures Summary

\begin{tabular}{l|l|l|l|l|l} 
& $\begin{array}{l}\text { Annual } \\
\text { Electricity } \\
\text { Savings } \\
\text { (kWh/yr) }\end{array}$ & $\begin{array}{l}\text { Annual } \\
\text { Natural } \\
\text { Gas } \\
\text { Savings } \\
\text { (therm/yr) }\end{array}$ & $\begin{array}{l}\text { Annual } \\
\text { Cost } \\
\text { Savings } \\
\mathbf{( \$ / y r )}\end{array}$ & $\begin{array}{l}\text { Installed } \\
\text { Cost } \\
\mathbf{( \$ )}\end{array}$ & $\begin{array}{l}\text { Simple } \\
\text { Payback } \\
\text { (yrs) }\end{array}$ \\
ECM Title & 14 & 16 & $\$ 11.5$ & $\$ 800$ & 70 \\
\hline $\begin{array}{l}\text { Add/Repair Ceiling Insulation } \\
\text { Program Thermostats }\end{array}$ & 105.8 & 116.5 & $\$ 83$ & 0 & 0 \\
$\begin{array}{l}\text { Reduce Plug Load Energy Use } \\
\text { via Wi-Fi Plug Load Outlet }\end{array}$ & 551 & -14 & $\$ 41$ & $\$ 120$ & 2.9 \\
$\begin{array}{l}\text { Retrofit LED Interior and Exterior } \\
\text { Lighting }\end{array}$ & 281 & -7 & $\$ 21$ & $\$ 200$ & 9.5 \\
$\begin{array}{l}\text { Reduce Infiltration in Home } \\
\text { Install ENERGYSTAR }\end{array}$ & 495 & 545.1 & $\$ 390$ & $\$ 1000$ & 2.6 \\
appliances & 740 & 26 & $\$ 83$ & $\$ 2650$ & 31 \\
\hline Combined & 2,187 & 682.6 & $\$ 630$ & $\$ 4,770$ & 7.6 \\
\hline
\end{tabular}




\section{Table of Contents}

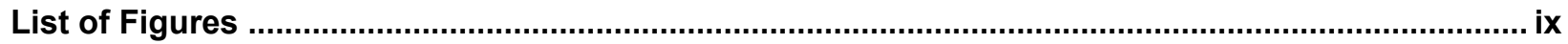

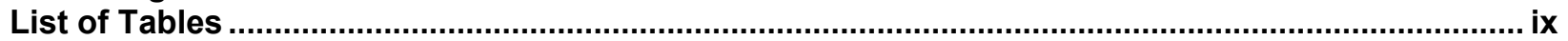

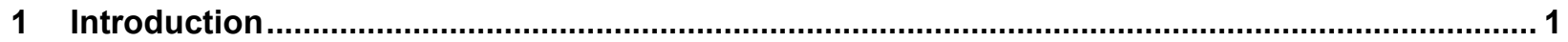

2 Tribal Housing

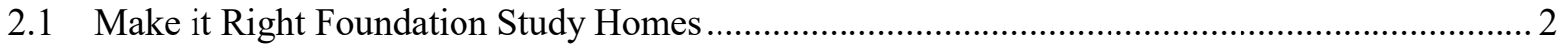

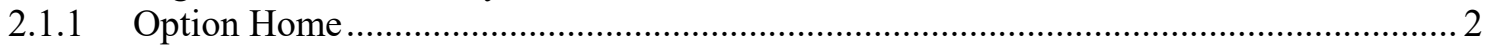

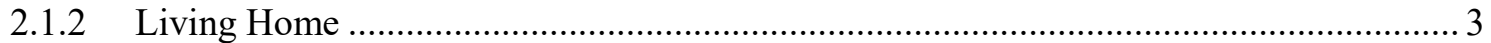

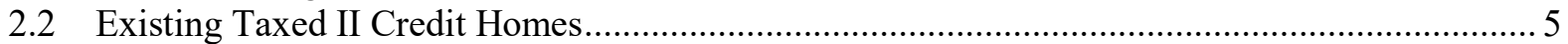

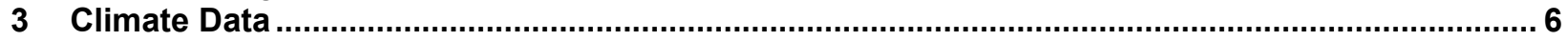

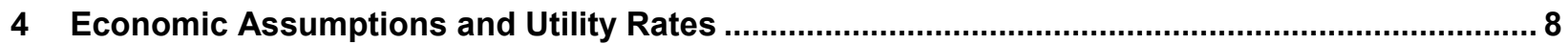

5 Modeling

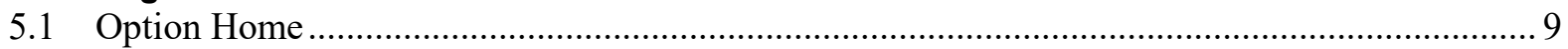

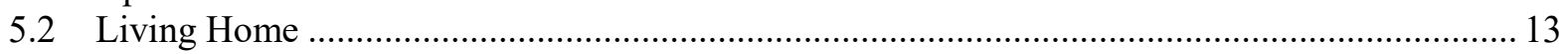

5.3 Existing Taxed II Credit Homes....................................................................................... 17

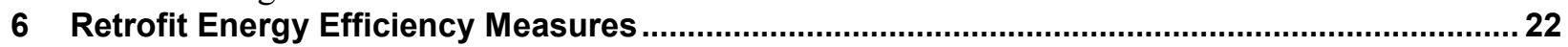

6.1 Option House Energy-Efficiency Measures...................................................................... 22

6.1.1 Educate Home Owners on Thermostat Operation....................................................... 22

6.1.2 Reduce Plug Load Energy Use with Wi-Fi Plug Load Wall Outlet............................. 22

6.1.3 Retrofit Interior CFL and Exterior Halogen Bulbs with LED Bulbs ............................ 23

6.1.4 Relocate Water Lines to Underside of Insulation and Repair Insulation in Crawlspace 24

6.2 Living House Energy-Efficient Measures ................................................................................ 24

6.2.1 Educate Home Owners on Thermostat Operation...................................................... 24

6.2.2 Reduce Plug Load Energy Use with Wi-Fi Plug Load Wall Outlet...............................25

6.2.3 Replace Interior CFL and Exterior Halogen Bulbs with LED Bulbs ............................. 26

6.2.4 Relocate Water Lines to Underside of Insulation and Repair Insulation in Crawlspace 26

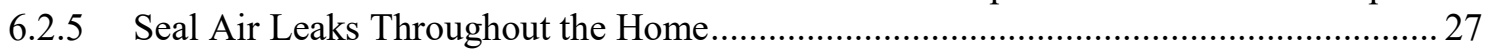

6.3 Taxed II Credit Home Energy-Efficiency Measures............................................................... 27

6.3.1 Educate Home Owners on Thermostat Operation....................................................... 27

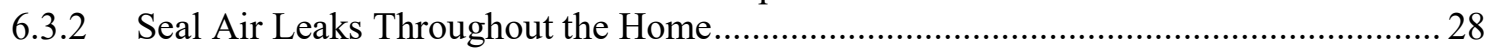

6.3.3 Retrofit Interior CFL and Exterior Halogen Bulbs with LED Bulbs ........................... 28

6.3.4 Reduce Plug Load Energy Use with Wi-Fi Plug Load Wall Outlet............................... 29

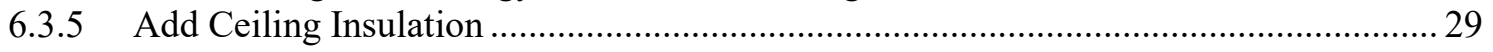

6.3.6 Install ENERGY STAR-Rated Appliances (Dishwasher, Clothes Washer, Clothes

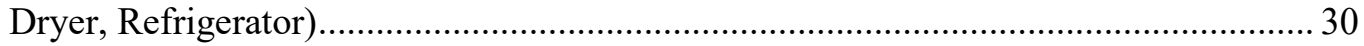

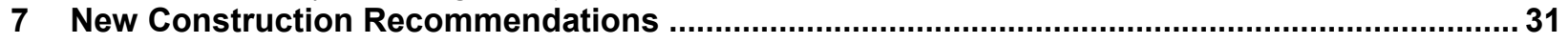

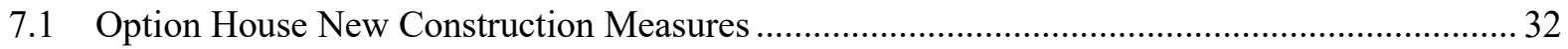

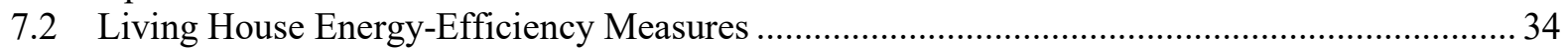

7.3 Existing Taxed II Credit Home New Construction Measures.................................................. 38

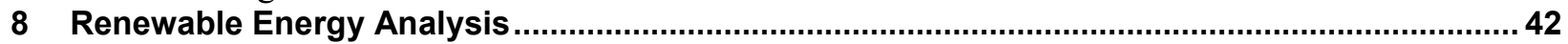

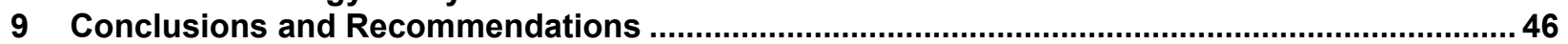

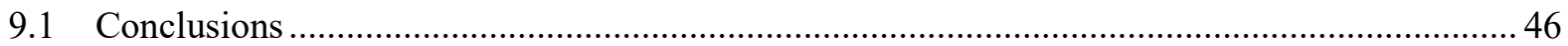

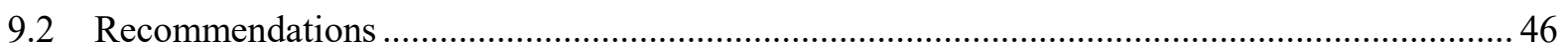

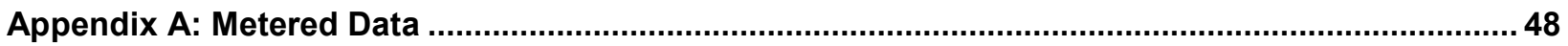

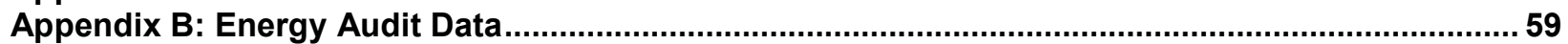




\section{List of Figures}

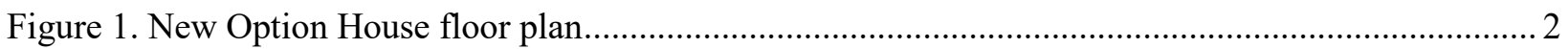

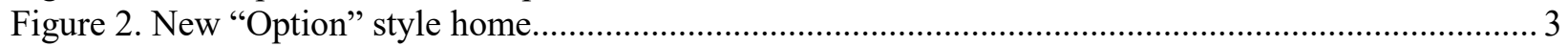

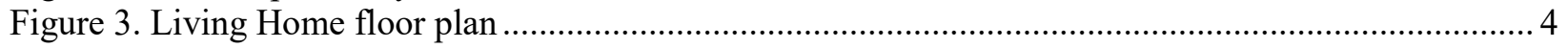

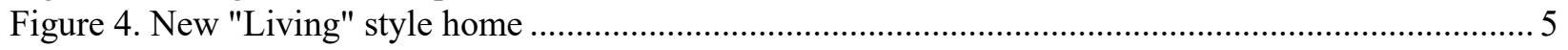

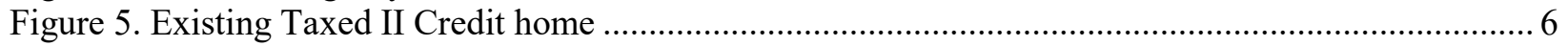

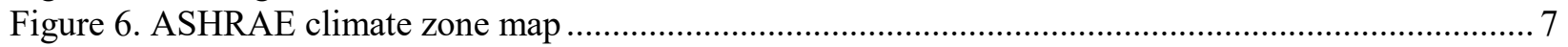

Figure 7. TMY3 hourly outside air temperature for Glasgow, Montana ............................................. 7

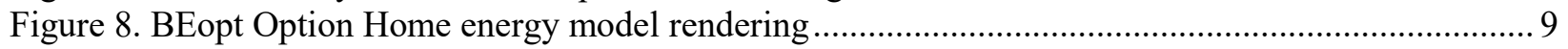

Figure 9. Option House annual energy use by end use .................................................................... 12

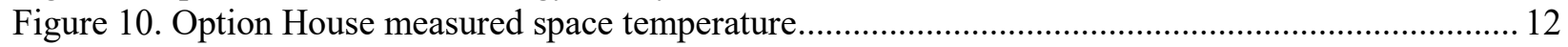

Figure 11. Option House hourly energy use profile .......................................................................... 13

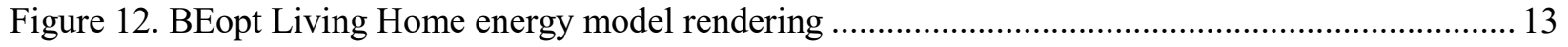

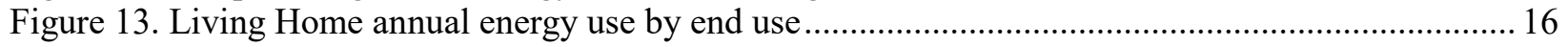

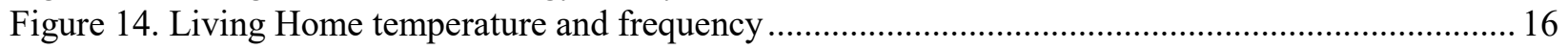

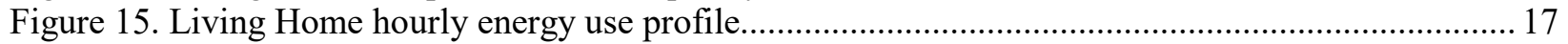

Figure 16. BEopt existing Taxed II Credit Home energy model rendering ............................................ 17

Figure 21. Living Home hourly electricity use average daily load profile .............................................25

Figure 23. Building configuration design options: energy costs vs. energy savings ............................... 31

Figure 24. Selected design options with lowest life-cycle cost ........................................................... 32

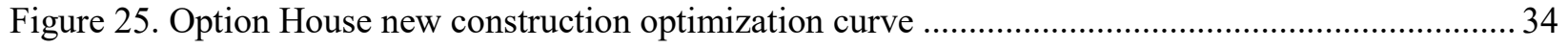

Figure 26. Baseline home energy use compared to minimum life-cycle cost design ............................... 38

Figure 27. Exiting Taxed II Credit Home new construction optimization curve ....................................... 41

Figure 28. Depiction of major components of grid-connected PV system ............................................. 42

Figure 29. 124 C St East 3D rooftop PV system rendering ................................................................. 43

\section{List of Tables}

Table ES-1. Option House Energy-Efficient Measures Summary .............................................................vi

Table ES-2. Living Home Energy-Efficient Measures Summary............................................................. vi

Table ES-3. Taxed II Credit Homes Energy-Efficient Measures Summary ...........................................vii

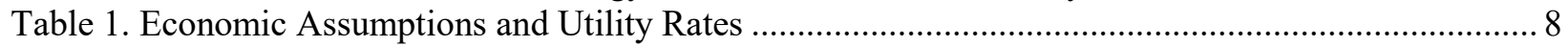

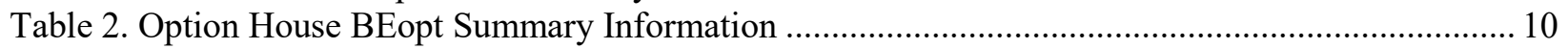

Table 3. Option House BEopt Summary Information \#2 …............................................................. 11

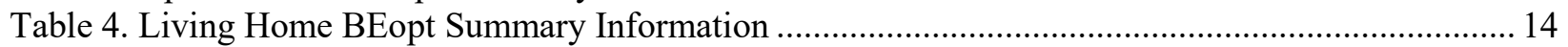

Table 5. Living Home BEopt Summary Information \#2 .................................................................... 15

Table 6. Existing Taxed II Credit Home BEopt Summary Information .................................................. 18

Table 7. Existing Taxed II Credit Home BEopt Summary Information \#2 …...................................... 19

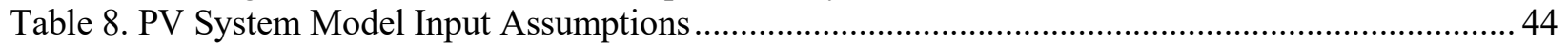

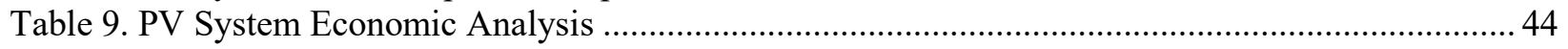




\section{Introduction}

This project provided design assistance to maximize energy performance for affordable housing at the Fort Peck Indian Reservation near Poplar, Montana. The Make It Right Foundation (MIRF) built 20 high-performing homes (Leadership in Energy and Environmental Design [LEED] Platinum) with five different design options. These 20 homes constitute Phase 1 of the planned eco-village at the Fort Peck Reservation.

Much of the housing on reservations falls short of meeting applicable energy codes and can result in increased energy use and associated energy costs. Reducing costs for residents can have an immediate impact on individual families and on the community as a whole. Equipped with an understanding of how these homes perform, Tribal Housing Authority representatives can see how individual components of the design contribute to increased energy performance that may be duplicated and implemented in future projects at Fort Peck and in communities on other tribal lands.

As described below, the National Renewable Energy Laboratory and the U.S. Environmental Protection Agency Region 8 set out to provide energy analysis along with measurement and verification of the homes to characterize energy use and provide clarity for future decision making regarding tribal housing options. The results included herein summarize the energy end uses and document projected energy impacts from various aspects of the MIRF home designs and construction.

This report includes an analysis of energy use in five MIRF homes, comparing energy use across the different styles and configurations. Energy models were created for two styles of MIRF homes, including a renewable energy assessment for photovoltaic (PV) systems. Existing tribal housing was also analyzed, with five housing units analyzed for energy use and an energy model created for one of the houses.

The energy modeling platform BEopt was used to simulate the energy used in the houses during every hour of the year. The energy models were calibrated using data from real-time data loggers installed at the utility meter and a year's worth of utility bills from Montana-Dakota Utilities. The energy models were used to evaluate energy-efficient measures that could be applied to existing homes and to evaluate design elements that could be implemented in any new builds that may be constructed in the future. For each housing style, BEopt helped identify the most costeffective set of energy conservation measures, on a lifecycle basis, and the design elements that should be incorporated into new house designs to achieve maximum energy performance. The analysis was performed for existing homes (energy-efficiency measures) and new homes (new construction designs).

This project is part of a larger effort that Region 8 is initiating to promote more highperformance housing on tribal lands by identifying where and how highly energy-efficient homes are being constructed and by demonstrating how overall cost of ownership can be lower than conventional housing and quantifying the environmental benefits of high-performance housing. 


\section{Tribal Housing}

The housing included in this study is located in Poplar, Montana. There are many styles and vintages of housing on the reservation, most of which are managed by the Tribal Housing Office. The two most recent housing styles are included in this study. The MIRF homes are located on the east side of town in a new development referred to as the "Eco Village." The other housing units included in the study are referred to as the "Taxed II Credit" homes. The objective of the study was to compare the MIRF homes to the next best alternative in terms of energy consumption and occupant comfort.

\subsection{Make it Right Foundation Study Homes}

MIRF began working with the Fort Peck community in June 2013 with community-driven design meetings. Members of the community and future homeowners met with the MIRF to discuss needs and a vision for their neighborhood. The homes were structured as a rent-to-own program where the ownership of the home is transferred to the tenants after 15 years. Construction of the homes was completed in late 2015.

\subsubsection{Option Home}

The option homes are 1,260 $\mathrm{ft}^{2}$ with three bedrooms and two bathrooms. The floor-to-ceiling height ranges from $8 \mathrm{ft}$ to $10 \mathrm{ft}$, and the homes face due east. An image of the floor plan is provided in Figure 1.

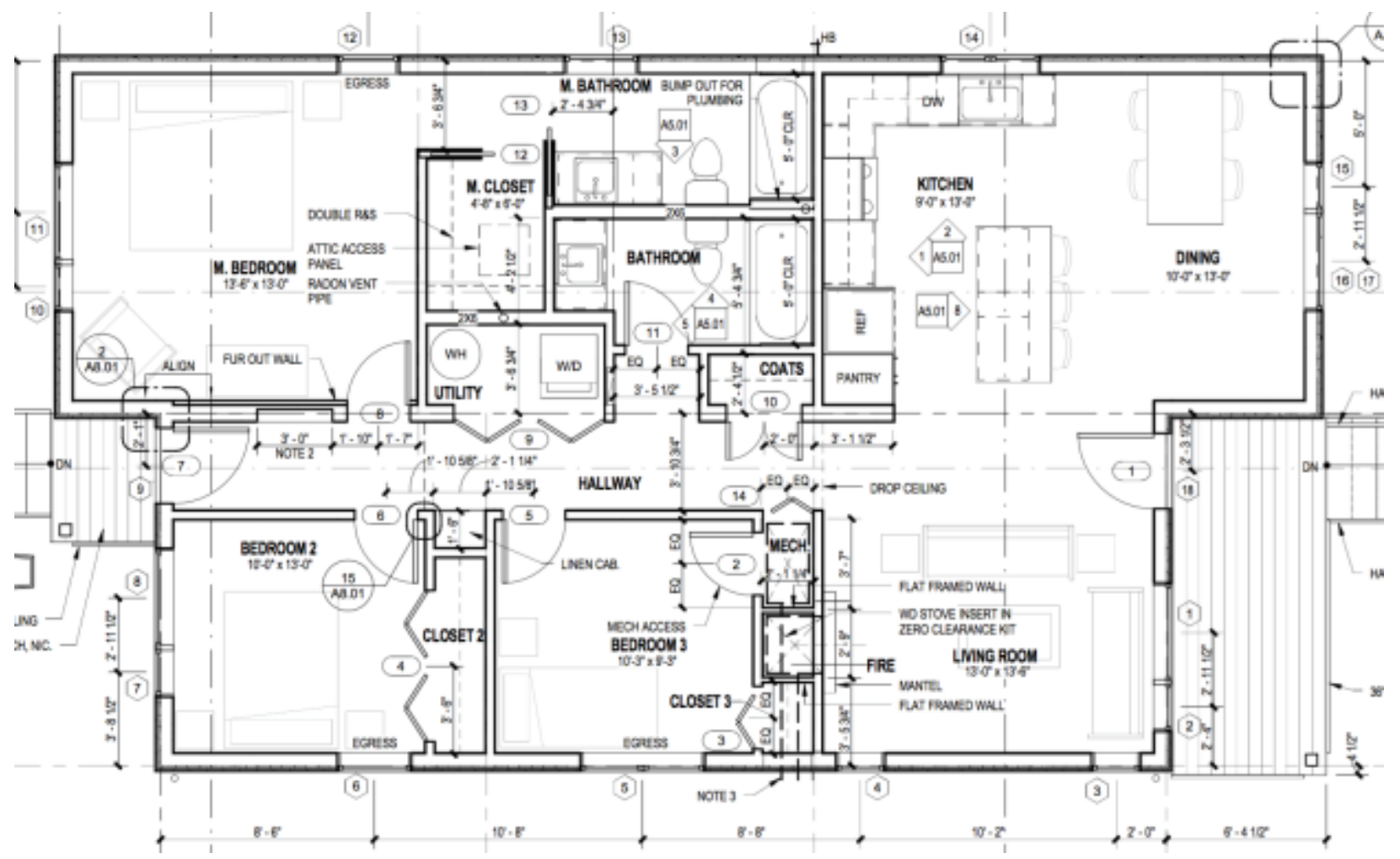

Figure 1. New Option House floor plan

The roof is constructed of structurally insulated panels with R-45 and a standing seam metal roof. The walls are constructed of $2 \times 6 \mathrm{~s}$ that are $16 \mathrm{in}$. on center with R-21 fiberglass batt 
insulation and R-4 exterior sheathing. The floor construction is a vented crawlspace with an insulated crawlspace ceiling. A picture of the Option Home is provided in Figure 2.

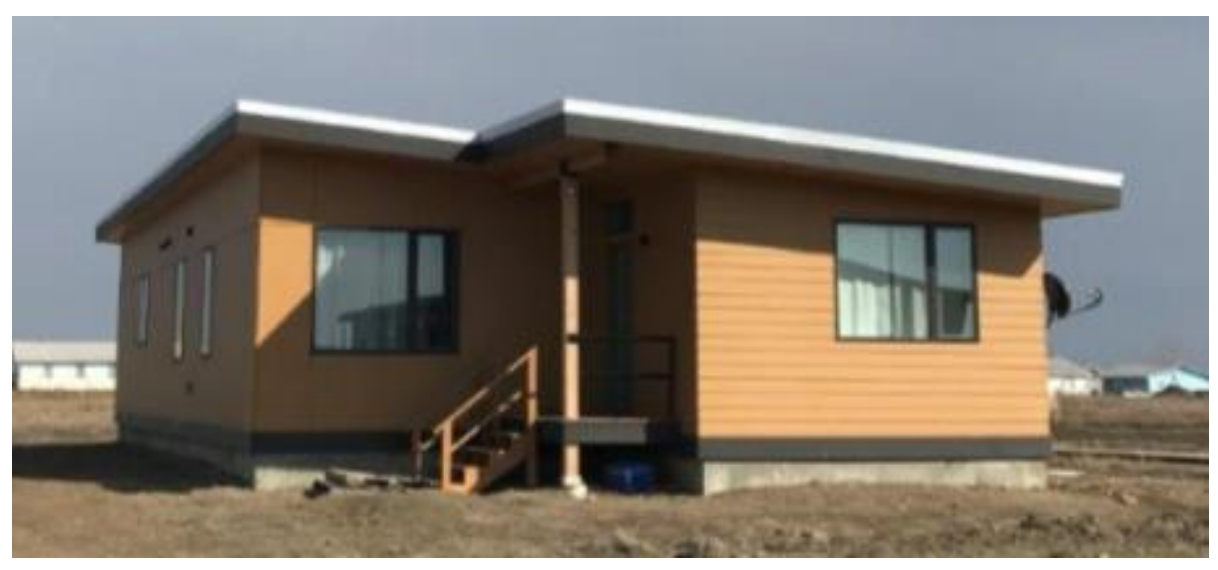

Figure 2. New "Option" style home

Photo Credit: Tim Rehder, EPA

The windows are Low-E double-paned windows, and the building envelope has an air change per hour $(\mathrm{ACH})$ leakage rate of $2.86 \mathrm{ACH} 50$ based on a blower door test conducted via an onsite energy audit. Mechanical ventilation is provided by a standard mechanical exhaust system. Air conditioning is provided by a 16 seasonal energy efficiency Ratio (SEER) central direct expansion air conditioner, and heating and domestic hot water (DHW) are provided by a $96 \%$ efficient condensing gas boiler. Interior lighting is a combination of compact fluorescent lighting (CFL) and light-emitting diode (LED) bulbs, and the clothes washer is an ENERGY STAR ${ }^{\circledR}$ clothes washer.

\subsubsection{Living Home}

The living homes are 1,517 $\mathrm{ft}^{2}$ with three bedrooms and two bathrooms. The floor-to-ceiling height ranges from $8 \mathrm{ft}$ to $10 \mathrm{ft}$, and the homes face due east. An image of the floor plan is provided in Figure 3. 


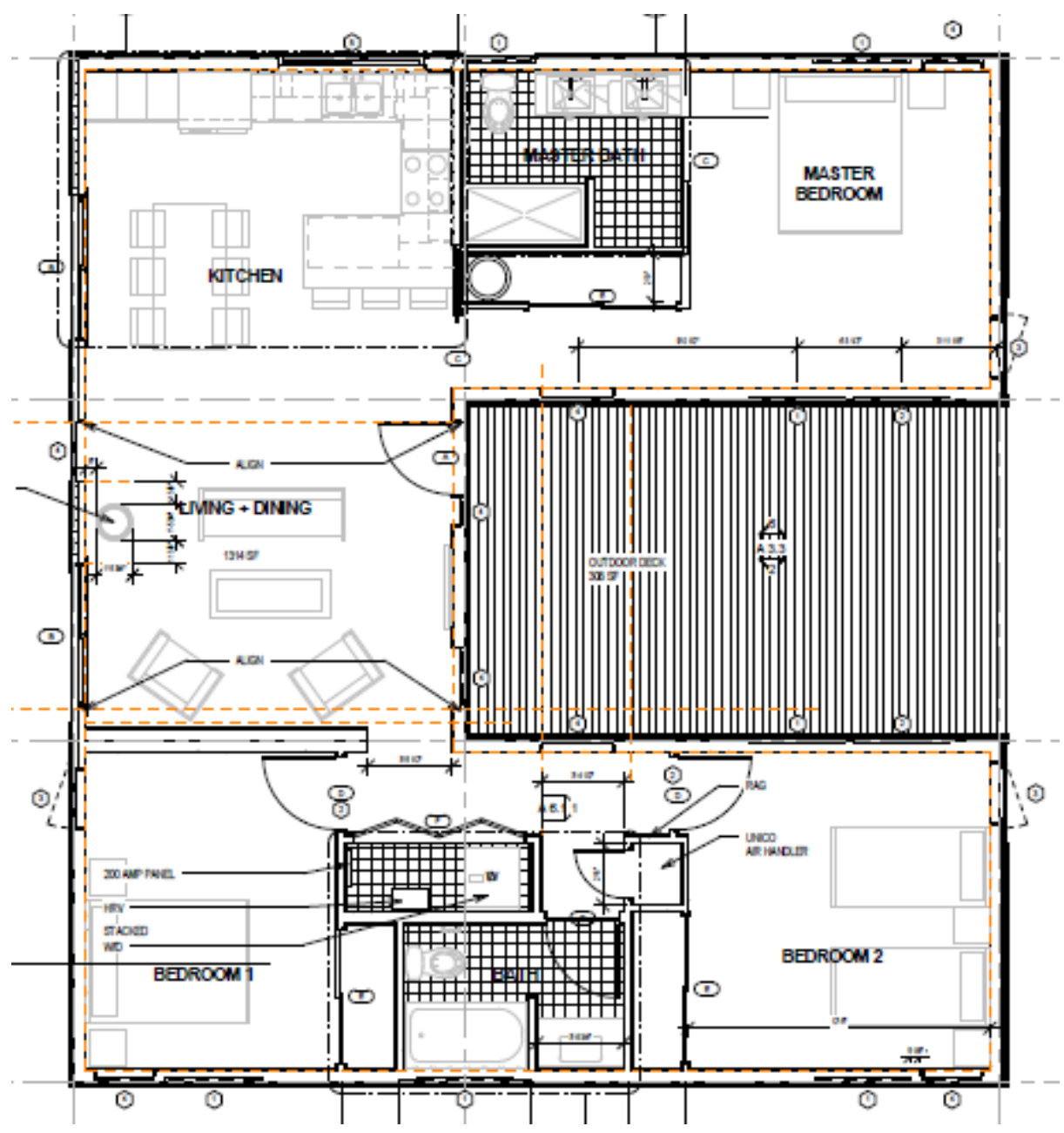

Figure 3. Living Home floor plan

The roof is constructed of structurally insulated panels with R-45 and a standing seam metal roof. The walls are constructed of $2 \times 6$ s that are 16 in. on center with R-21 fiberglass batt insulation and R-4 exterior sheathing. The floor construction is a vented crawlspace with an insulated crawlspace ceiling. 


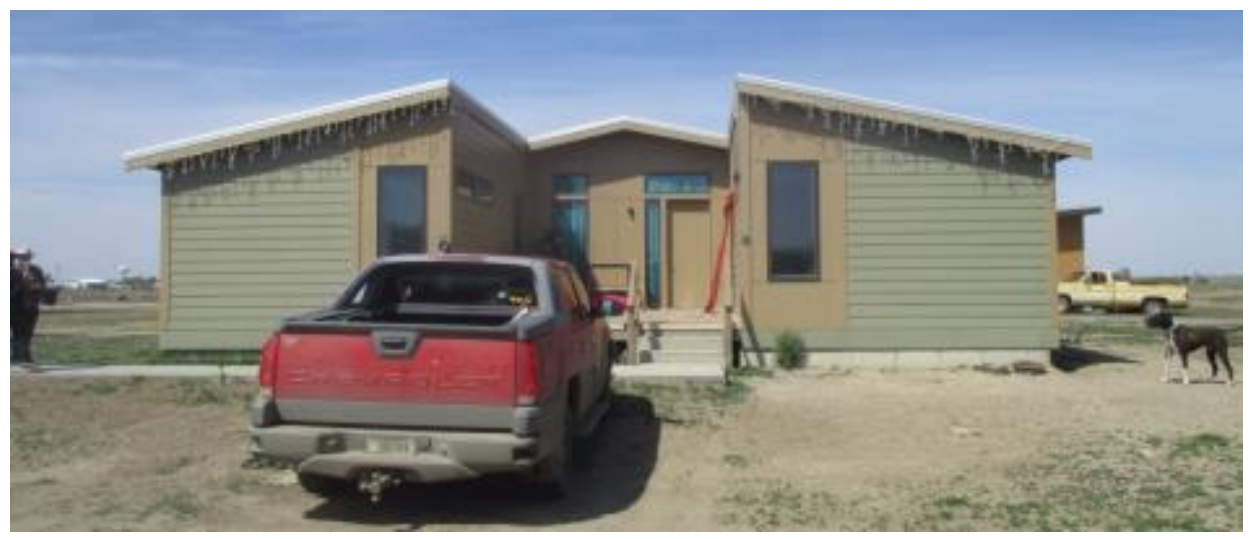

Figure 4. New "Living" style home

Photo Credit: Tim Rehder, EPA

The windows are Low-E double-paned windows, and the building envelope has an ACH leakage rate of $4.8 \mathrm{ACH}$. Air conditioning is provided by a 16 SEER central direct expansion air conditioner, and heating and DHW are provided by a $96 \%$ efficient condensing gas boiler. Interior lighting is a combination of CFL and LED bulbs and the clothes washer is an ENERGY STAR clothes washer.

\subsection{Existing Taxed II Credit Homes}

The Existing Taxed II Credit homes are 1,650 $\mathrm{ft}^{2}$ with three bedrooms and two bathrooms. The floor-to-ceiling height ranges from $8 \mathrm{ft}$ to $10 \mathrm{ft}$, and the homes face north. The roof is constructed of structurally insulated panels with R-45 and a standing seam metal roof. The walls are constructed of $2 \times 6 \mathrm{~s}$ that are $16 \mathrm{in}$. on center with R-19 fiberglass batt insulation. The floor construction is an unvented crawlspace with insulated crawlspace walls. A picture of the Existing Taxed II Credit homes is provided in Figure 5. 


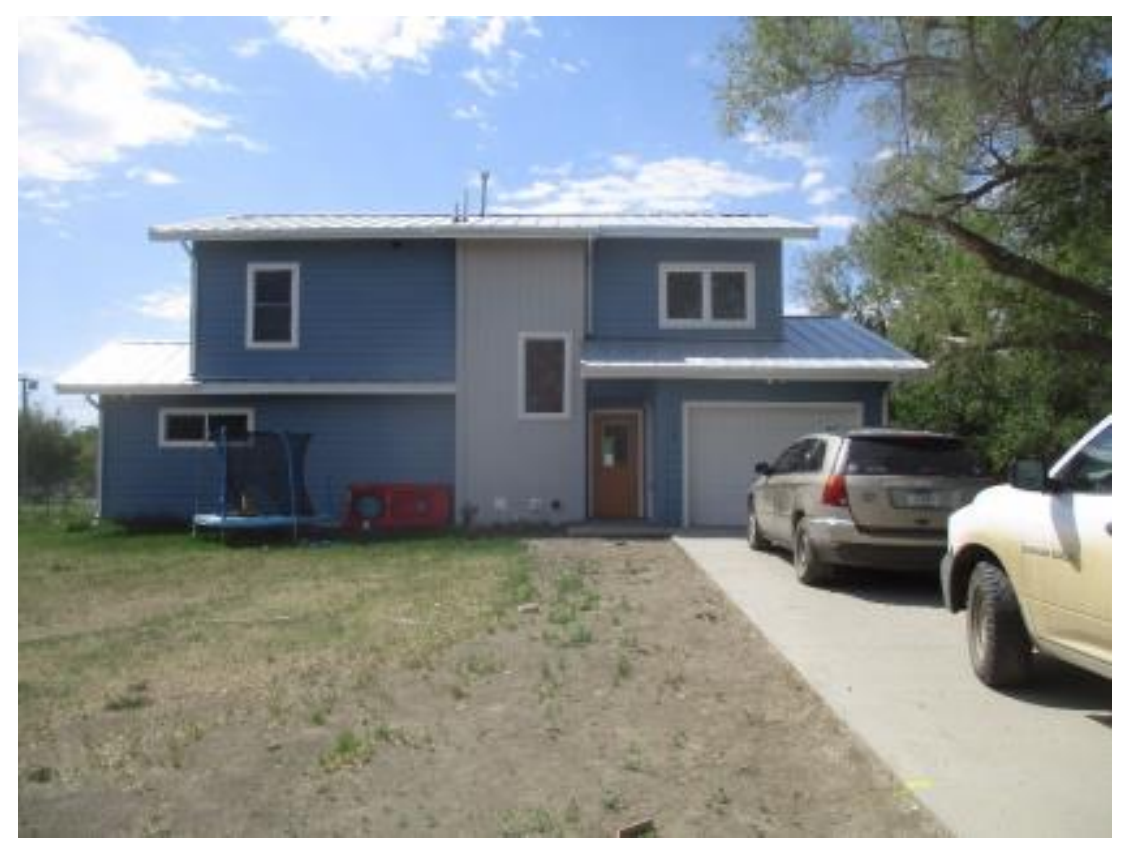

Figure 5. Existing Taxed II Credit home

Photo Credit: Tim Rehder, EPA

The windows are Low-E double-paned windows, and the building envelope has an ACH leakage rate of 14.5 ACH. The home uses a whole house fan for cooling in the summer and forced-air natural gas heating in the winter. A heat recovery ventilator has been installed for fresh air. DHW is provided by a 50-gallon gas storage water heater with an energy factor (EF) of 0.56. Interior lighting is a combination of CFL/LED and incandescent, and no appliances are ENERGY STAR rated.

\section{Climate Data}

Poplar is a small town located in Valley County, Montana, in the northeast corner of Montana. The site is at an elevation of $2,067 \mathrm{ft}$ at latitude $48^{\circ} \mathrm{N}$ and longitude $106.27^{\circ} \mathrm{W}$. The entire state of Montana is in ASHRAE climate zone $6 \mathrm{~B}$, which is characterized as a cold and dry climate with 7,200 to 9,000 heating degree-days at a balance temp of $65^{\circ} \mathrm{F}$ (Figure 6). 


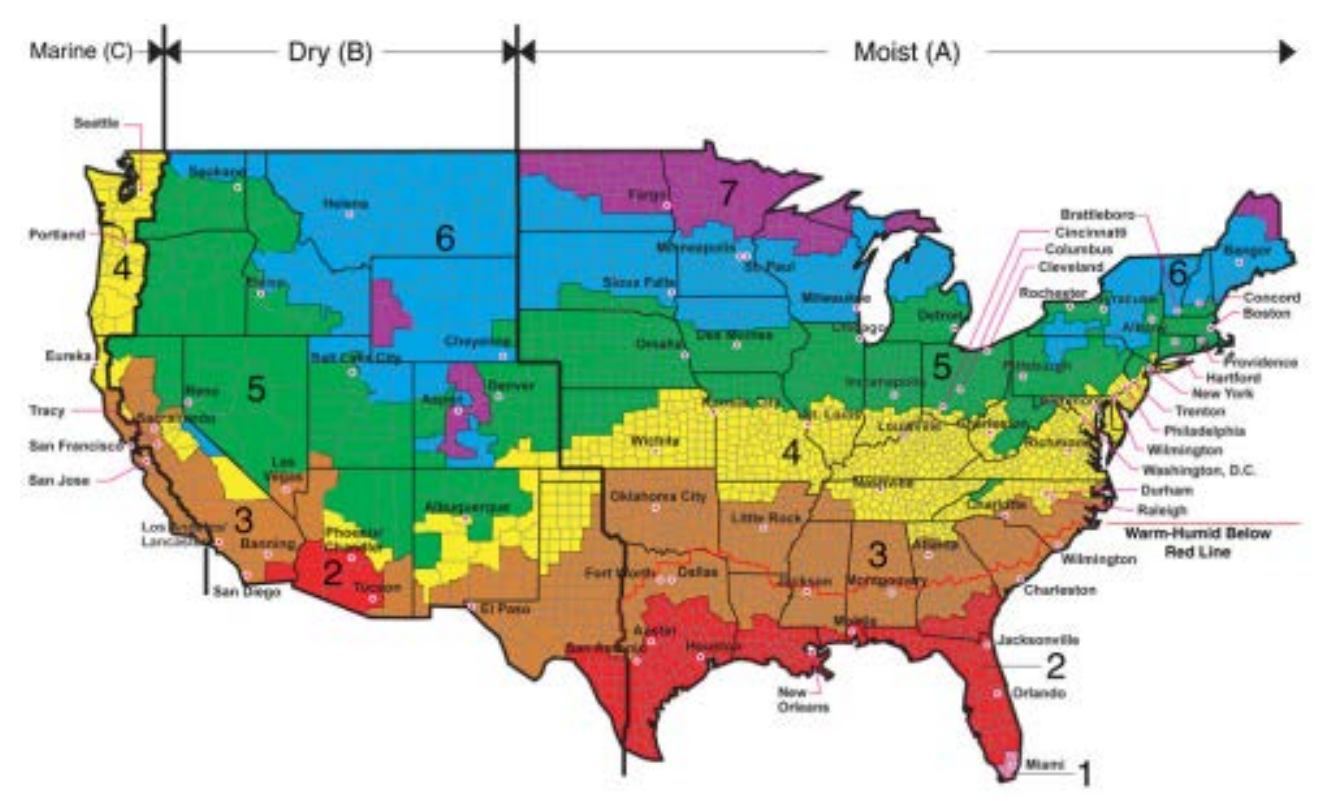

Figure 6. ASHRAE climate zone map

The closest Typical Meteorological Year (TMY3) weather location to Fort Peck is Glasgow, Montana. The outside air temperature for Glasgow / Fort Peck is below $60^{\circ} \mathrm{F}$ for most of the year. Figure 7 shows that there is some need for air conditioning for a short, 3-month period during the summer, with peak summer time temperatures in the $95^{\circ} \mathrm{F}$ to $100^{\circ} \mathrm{F}$ range.

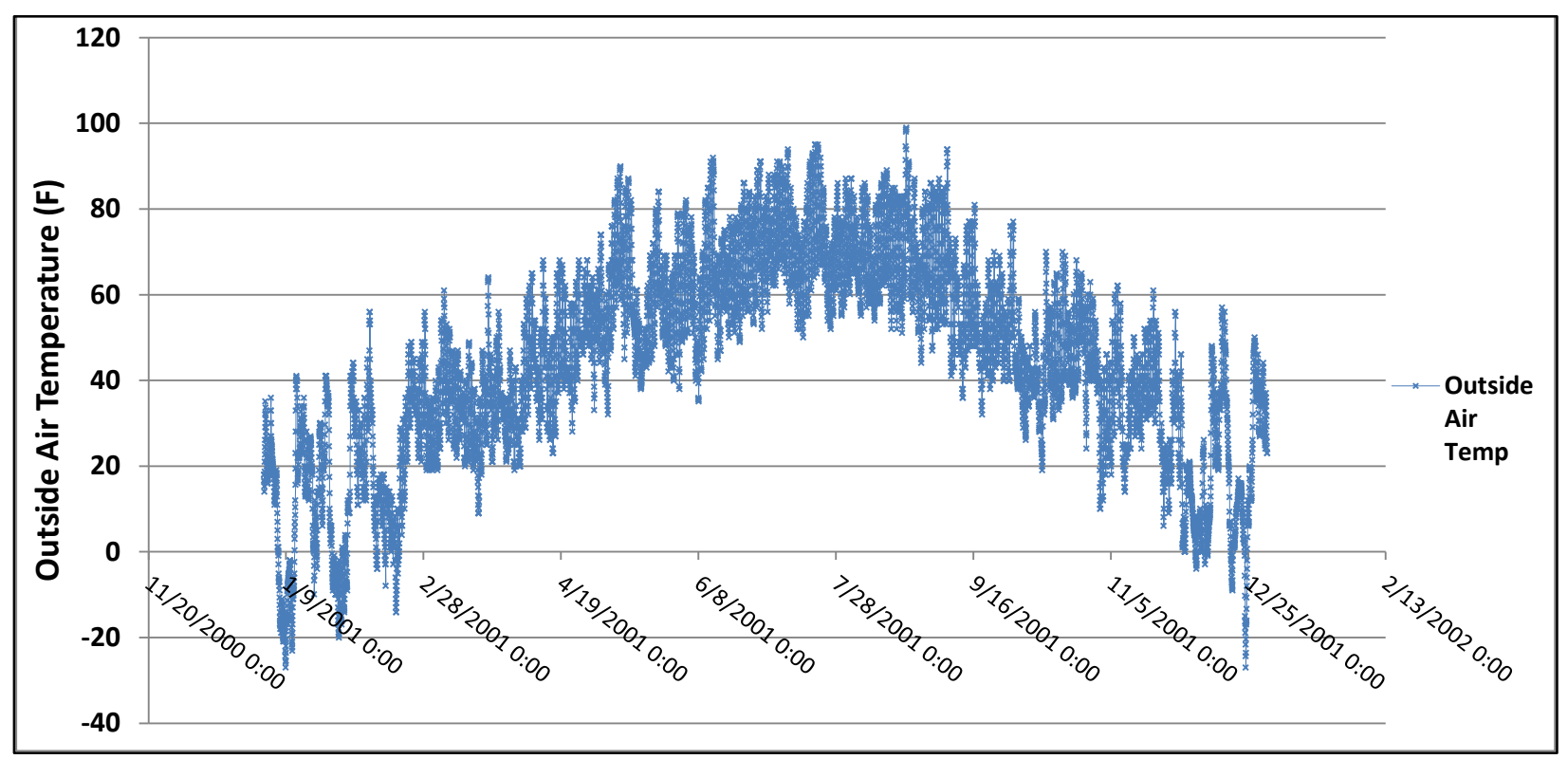

Figure 7. TMY3 hourly outside air temperature for Glasgow, Montana 


\section{Economic Assumptions and Utility Rates}

The analysis period that was used for this study was 30 years, with an inflation rate of $2.4 \%$, a real discount rate of 3\% and a nominal discount rate of 5.4\% (Table 1). Electricity and Natural Gas are provided by Montana Dakota Utilities. The current electric rate is $\$ 0.086 /$ kilowatt-hour $(\mathrm{kWh}$, ) and natural gas is $\$ 0.65 /$ therm.

Table 1. Economic Assumptions and Utility Rates

\begin{tabular}{l|l|l}
\hline \multicolumn{3}{l}{ Economics and Utility Rates } \\
\hline \multirow{4}{*}{ Economics } & Analysis Period (years) & 30 \\
& Inflation Rate (\%) & $2.4 \%$ \\
& Real Discount Rate (\%) & $3 \%$ \\
\hline \multirow{5}{*}{ Electric Rate } & Fixed Electric Charge (\$/month) & $\$ 5.27$ \\
& Electric Rate (\$/kWh) & $\$ 0.086$ \\
& Electric Escalation Rate (\%) & $0.36 \%$ \\
\hline \multirow{5}{*}{ Ratural Gas } & $\begin{array}{l}\text { Fixed Natural Gas Charge } \\
(\$ / \text { month) }\end{array}$ & $\$ 7.13$ \\
& $\begin{array}{l}\text { Natural Gas Rate (\$/therm) } \\
\text { Natural Gas Escalation Rate } \\
(\%)\end{array}$ & $\$ 0.65$ \\
\hline
\end{tabular}

These economic assumptions are used when calculating life-cycle cost economics in the energy models. 


\section{Modeling}

Calibrated hourly energy simulations were created in the energy modeling platform BEopt ${ }^{\mathrm{TM}}$. The BEopt(Building Energy Optimization) software provides capabilities to evaluate residential building designs and identify cost-optimal efficiency packages at various levels of whole-house energy savings along the path to zero net energy.

BEopt provides detailed simulation-based analysis based on specific house characteristics, such as size, architecture, occupancy, vintage, location, and utility rates. Discrete envelope and equipment options, reflecting realistic construction materials and practices, are evaluated.

BEopt uses EnergyPlus, the U.S. Department of Energy's flagship simulation engine. Simulation assumptions are based on the Building America Housing Simulation Protocols.

BEopt can be used to find optimal life-cycle cost building designs using an optimization to determine the best energy choices based on minimizing cost. The sequential search optimization technique used by BEopt:

- Finds minimum-cost building designs at different target energy-savings levels

- Identifies multiple near-optimal designs along the path, allowing for equivalent solutions based on builder or contractor preference.

BEopt has been developed by the National Renewable Energy Laboratory in support of the U. S. Department of Energy Building America program goal to develop market-ready energy solutions for new and existing homes. ${ }^{2}$

\subsection{Option Home}

The Option Home is a single-story, single-family home that was built as part of the sustainable village in Poplar, Montana. The homes were manufactured in Washington State and moved into place on permanent foundations. A graphical representation of the Option Home as modeled in BEopt is provided in Figure 8.

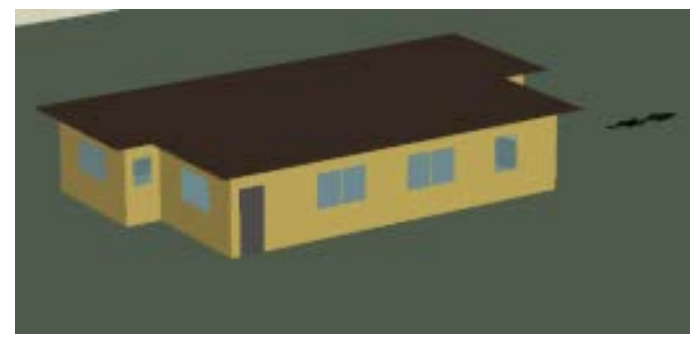

Figure 8. BEopt Option Home energy model rendering

The Option Home uses a combi-unit water heater that provides hot water for DHW and for space heating. The hot water is piped from the water heater to a water-to-air heat exchanger for space heating. The homes were designed with a vented, unconditioned crawlspace and a vapor barrier.

\footnotetext{
2 https://beopt.nrel.gov/
} 
The general facility characteristics that were modeled in BEopt for the Option Home are provided in Table 2.

Table 2. Option House BEopt Summary Information

\begin{tabular}{|c|c|c|}
\hline \multicolumn{3}{|c|}{ Option House BEopt Model } \\
\hline Location & Weather File & TMY 3 MT Glasgow \\
\hline Building & $\begin{array}{l}\text { Size }\left(\mathrm{ft}^{2}\right) \\
\text { Number of Bed / } \\
\text { Bath } \\
\text { Orientation } \\
\text { Neighbors }\end{array}$ & $\begin{array}{l}1,260 \\
3 / 2 \\
\text { East } \\
\text { None }\end{array}$ \\
\hline Walls & $\begin{array}{l}\text { Wood Stud } \\
\text { Wall Sheathing } \\
\text { Exterior Finish }\end{array}$ & $\begin{array}{l}\text { R- } 21 \text { fiberglass batt } 2 \times 616 " \text { on } \\
\text { center } \\
\text { R-4 exterior sheathing } \\
\text { Wood siding / light paint }\end{array}$ \\
\hline Ceiling Roof & $\begin{array}{l}\text { Roof } \\
\text { Roof Finish }\end{array}$ & $\begin{array}{l}\text { SIP w/ R-45 } \\
\text { Standing seam metal / dark finish }\end{array}$ \\
\hline Foundation & $\begin{array}{l}\text { Slab / Crawlspace } \\
\text { Carpet }\end{array}$ & $\begin{array}{l}\text { Vented crawlspace with } \mathrm{R}-19 \text { batts } \\
60 \% \text { carpet }\end{array}$ \\
\hline Windows and Doors & $\begin{array}{l}\text { Window Area } \\
\text { Windows } \\
\text { Doors } \\
\text { Eaves }\end{array}$ & $\begin{array}{l}211 \mathrm{ft}^{2} \\
\text { Low-E Double / nonmetal ( } \mathrm{U} \text { value } \\
0.35 \text {, SHGC } 0.44) \\
\text { Fiberglass } \\
2 \mathrm{ft}\end{array}$ \\
\hline Airflow & $\begin{array}{l}\text { Air leakage } \\
\text { Mechanical } \\
\text { Ventilation }\end{array}$ & $\begin{array}{l}0.16 \mathrm{ACH} \\
\text { Standard Mechanical exhaust }\end{array}$ \\
\hline Space Conditioning & $\begin{array}{l}\text { Central Air } \\
\text { Conditioner } \\
\text { Boiler } \\
\text { Ducts }\end{array}$ & $\begin{array}{l}\text { SEER } 16,1 \text { stage } \\
\text { Condensing Gas, 96\% AFUE } \\
\text { Crawlspace } 15 \% \text { leakage, R-5 }\end{array}$ \\
\hline
\end{tabular}

AFUE = annual fuel use efficiency

SHGC = solar heat gain coefficient 
Table 3. Option House BEopt Summary Information \#2

\begin{tabular}{|c|c|c|}
\hline \multicolumn{3}{|c|}{ Option House BEopt Model } \\
\hline $\begin{array}{l}\text { Space } \\
\text { Conditioning } \\
\text { Schedules }\end{array}$ & $\begin{array}{l}\text { Cooling Set } \\
\text { Point } \\
\text { Heating Set } \\
\text { Point }\end{array}$ & $\begin{array}{l}70^{\circ} \mathrm{F} \text { constant } \\
72^{\circ} \mathrm{F} \text { constant }\end{array}$ \\
\hline Water Heating & $\begin{array}{l}\text { Water Heater } \\
\text { Distribution }\end{array}$ & $\begin{array}{l}\text { Condensing Gas, 96\% AFUE } \\
\text { Uninsulated PEX }\end{array}$ \\
\hline Lighting & Lighting & $40 \%$ LED / $60 \%$ CFL \\
\hline Appliances & $\begin{array}{l}\text { Refrigerator } \\
\text { Cooking Range } \\
\text { Dishwasher } \\
\text { Clothes Washer } \\
\text { Clothes Dryer } \\
\text { Plug Loads } \\
\text { Domestic Hot } \\
\text { Water Use } \\
\text { Block heater }\end{array}$ & $\begin{array}{l}\text { Top Freezer } 18 \mathrm{ft}^{3} \\
\text { Electric } \\
\text { Standard with } 120 \% \text { use } \\
\text { ENERGY STAR w/ hot /cold cycles and } \\
120 \% \text { use } \\
\text { Electric } \\
200 \% \text { of default plug load use } \\
\text { DHW use from sinks, shower and baths } \\
\text { increased to } 246 \% \text { of default use } \\
\text { External electrical load added to account } \\
\text { for block heaters }\end{array}$ \\
\hline
\end{tabular}

The total site energy use for the Option Home is provided in Figure 9 and shows that heating and DHW energy use are the two largest loads in the building with heating energy use making up $50.33 \%$ of the total and DHW energy use making up $29.75 \%$ of energy use, followed by plug load energy use (Misc E) making up $21.67 \%$ of the total energy use. 


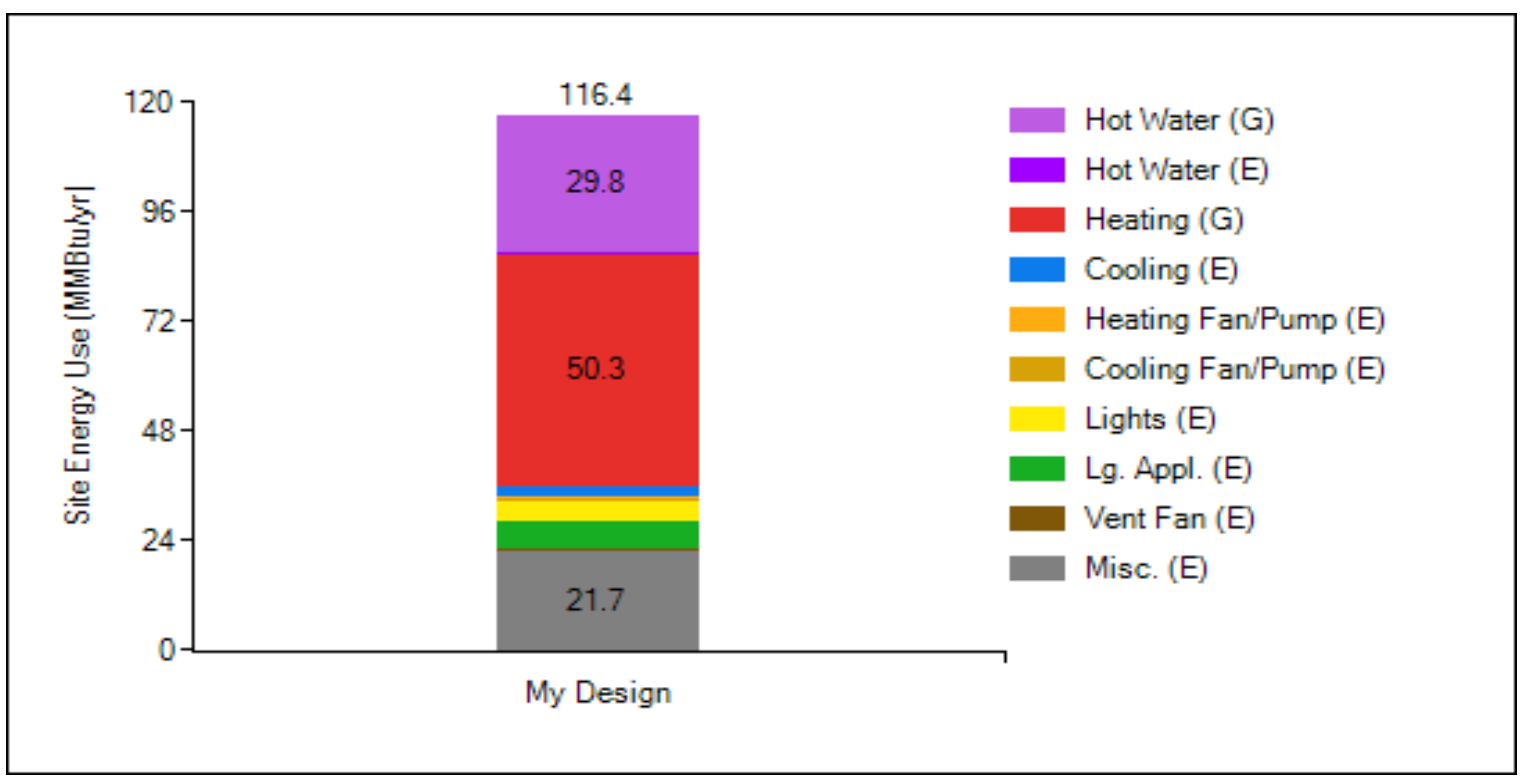

Figure 9. Option House annual energy use by end use

The average daily space temperature ranged from $66^{\circ} \mathrm{F}$ to $77^{\circ} \mathrm{F}$ and did not show a strong correlation with daily average outside air temperature, although it did show a trend towards lower space temperatures as the daily average outside air temperature increased. Based on the linear curve fit in Figure 10, the cooling space temperature was modeled as $70^{\circ} \mathrm{F}$, and the heating space temperature was modeled as $72^{\circ} \mathrm{F}$.

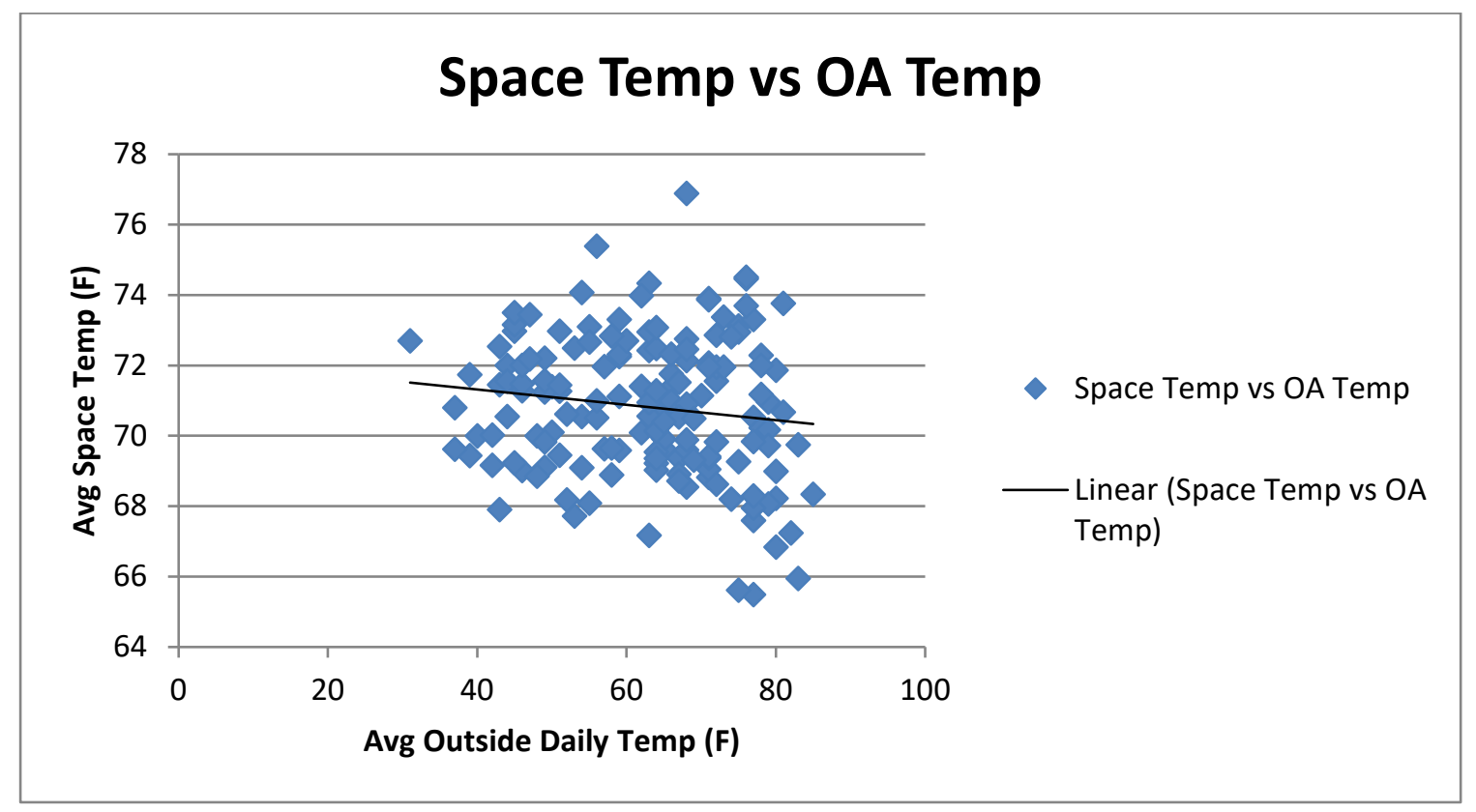

Figure 10. Option House measured space temperature

The average, maximum, and minimum hourly energy use was calculated for the period from $3 / 28 / 2017$ to $7 / 19 / 2017$ to identify trends in the daily use patterns (Figure 11). The analysis shows a consistent baseload power for the house that averages 800 watts to 2,100 watts, indicating the residents are likely leaving a large percentage of the plug loads in the home 
energized throughout the day and shows that plug load control strategies are likely to help reduce the total electricity energy use.

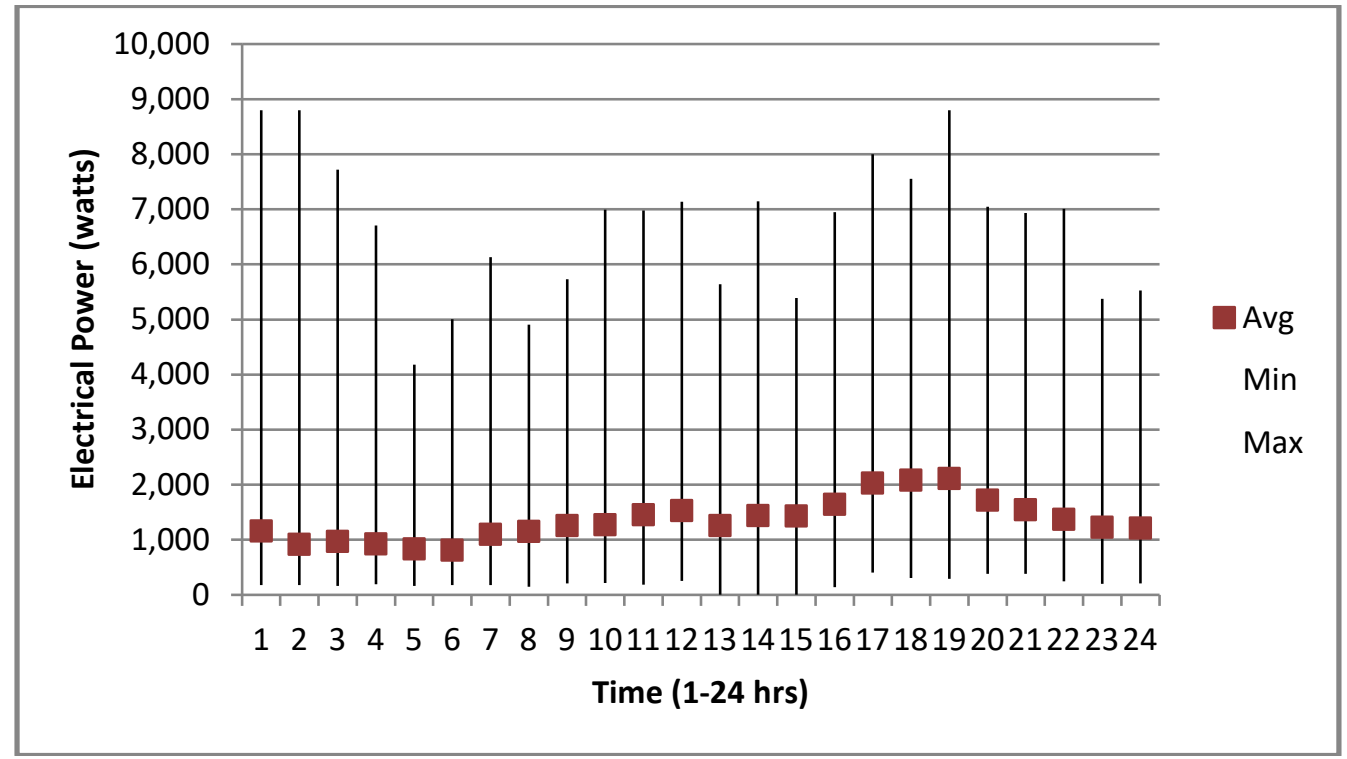

Figure 11. Option House hourly energy use profile

\subsection{Living Home}

The Living Home is a single-story, single-family home that was built as part of the sustainable village in Poplar, Montana. The homes were manufactured in Washington State and moved into place on permanent foundations. A graphical representation of the Living Home as modeled in BEopt is provided in Figure 12.

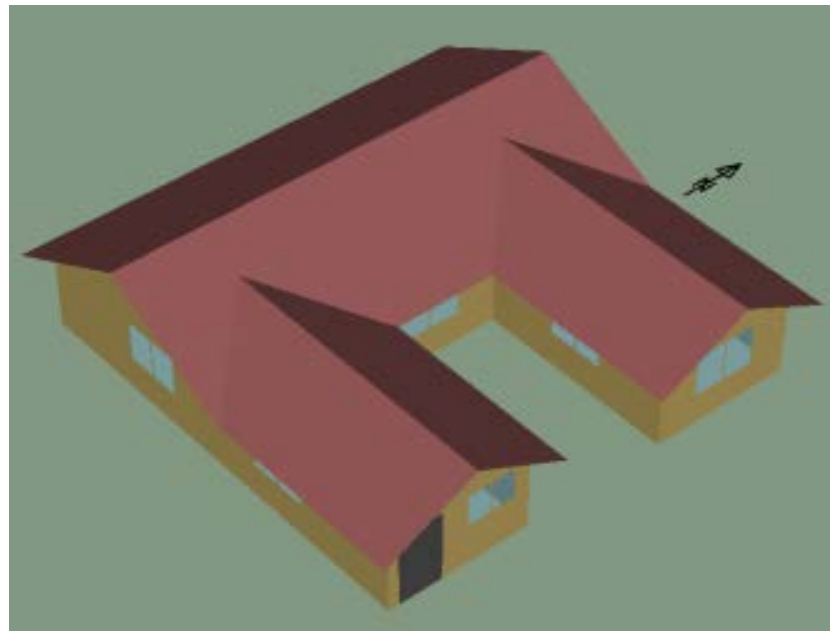

Figure 12. BEopt Living Home energy model rendering

The Living Home utilizes a combi-unit water heater that provides hot water for DHW and for space heating. The hot water is piped from the water heater to a water-to-air heat exchanger for space heating. The homes were designed with a vented, unconditioned crawlspace and a vapor barrier. The general facility characteristics modeled in BEopt for the Living Home are provided in Table 4 and Table 5. 
Table 4. Living Home BEopt Summary Information

\begin{tabular}{|c|c|c|}
\hline \multicolumn{3}{|c|}{ Living Home BEopt Model } \\
\hline Location & Weather File & TMY 3 MT Glasgow \\
\hline Building & $\begin{array}{l}\text { Size }\left(\mathrm{ft}^{2}\right) \\
\text { Number of Bed / } \\
\text { Bath } \\
\text { Orientation } \\
\text { Neighbors }\end{array}$ & $\begin{array}{l}1,517 \\
3 / 2 \\
\text { East } \\
\text { None }\end{array}$ \\
\hline Walls & $\begin{array}{l}\text { Wood Stud } \\
\text { Wall Sheathing } \\
\text { Exterior Finish }\end{array}$ & $\begin{array}{l}\text { R-21 fiberglass Batt } 2 \times 616 " \text { on } \\
\text { center } \\
\text { R-4 exterior sheathing } \\
\text { Wood siding / light paint }\end{array}$ \\
\hline Ceiling Roof & $\begin{array}{l}\text { Roof } \\
\text { Roof Finish }\end{array}$ & $\begin{array}{l}\text { SIP w/ R-45 } \\
\text { Standing seam metal / dark finish }\end{array}$ \\
\hline Foundation & $\begin{array}{l}\text { Slab / Crawlspace } \\
\text { Carpet }\end{array}$ & $\begin{array}{l}\text { Vented crawlspace with R19 Batts } \\
60 \% \text { carpet }\end{array}$ \\
\hline Windows and Doors & $\begin{array}{l}\text { Window Area } \\
\text { Windows } \\
\text { Doors } \\
\text { Eaves }\end{array}$ & $\begin{array}{l}284 \mathrm{ft}^{2} \\
\text { Low-E Double / nonmetal ( } \mathrm{U} \text { value } \\
0.35, \text { SHGC } 0.44) \\
\text { Fiberglass } \\
2 \mathrm{ft} \\
\end{array}$ \\
\hline Airflow & $\begin{array}{l}\text { Air leakage } \\
\text { Mechanical } \\
\text { Ventilation }\end{array}$ & $\begin{array}{l}10 \mathrm{ACH} \\
\text { Standard Mechanical exhaust }\end{array}$ \\
\hline Space Conditioning & $\begin{array}{l}\text { Central Air } \\
\text { Conditioner } \\
\text { Boiler } \\
\text { Ducts }\end{array}$ & $\begin{array}{l}\text { SEER } 16,1 \text { stage } \\
\text { Condensing Gas, } 96 \% \text { AFUE } \\
\text { Crawlspace } 15 \% \text { leakage, } \\
\text { Uninsulated }\end{array}$ \\
\hline
\end{tabular}


Table 5. Living Home BEopt Summary Information \#2

\begin{tabular}{|c|c|c|}
\hline \multicolumn{3}{|c|}{ Living Home BEopt Model } \\
\hline $\begin{array}{l}\text { Space } \\
\text { Conditioning } \\
\text { Schedules }\end{array}$ & $\begin{array}{l}\text { Cooling Set } \\
\text { Point } \\
\text { Heating Set } \\
\text { Point }\end{array}$ & $\begin{array}{l}74^{\circ} \mathrm{F} \text { constant } \\
72^{\circ} \mathrm{F} \text { constant }\end{array}$ \\
\hline Water Heating & $\begin{array}{l}\text { Water Heater } \\
\text { Distribution }\end{array}$ & $\begin{array}{l}\text { Condensing Gas, Tankless } 96 \% \text { AFUE } \\
\text { Uninsulated PEX }\end{array}$ \\
\hline Lighting & Lighting & $40 \%$ LED / $60 \%$ CFL \\
\hline Appliances & $\begin{array}{l}\text { Refrigerator } \\
\text { Cooking Range } \\
\text { Dishwasher } \\
\text { Clothes Washer } \\
\text { Clothes Dryer } \\
\text { Plug Loads } \\
\text { Domestic Hot } \\
\text { Water Use } \\
\text { Block heater } \\
\text { Block heater }\end{array}$ & $\begin{array}{l}\text { Top Freezer } 18 \mathrm{ft}^{3} \\
\text { Electric } \\
\text { Standard with } 120 \% \text { use } \\
\text { ENERGY STAR w/ hot /cold cycles and } \\
120 \% \text { use } \\
\text { Electric } \\
200 \% \text { of default plug load use } \\
\text { DHW use from sinks, shower and baths } \\
\text { increased to } 246 \% \text { of default use } \\
\text { External electrical load added to account } \\
\text { for block heaters } \\
\text { External electrical load added to account } \\
\text { for block heaters }\end{array}$ \\
\hline
\end{tabular}

The total site energy use for the Living Home is provided in Figure 13 and shows that heating and miscellaneous electrical (plug loads) energy use are the two largest loads in the building with heating energy use making up $26.7 \%$ of the total and miscellaneous electrical use making up $42.9 \%$ of energy use, followed by DHW use making up $12.7 \%$ of the total energy use. 


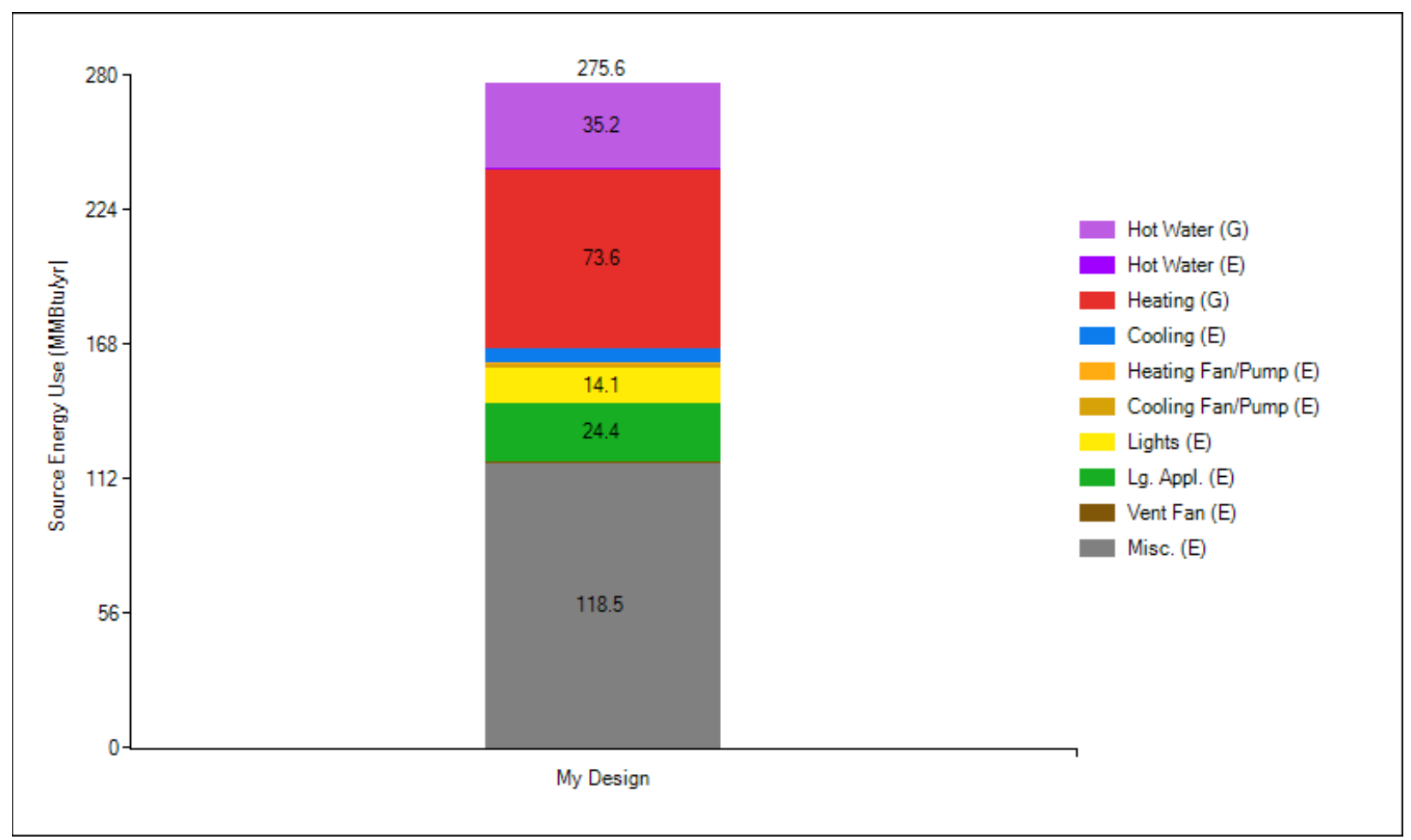

Figure 13. Living Home annual energy use by end use

Three temperature measurements were taken in the home during the monitoring period, indicating that in general, the home is maintaining comfortable conditions. The kitchen had a substantial number of hours below the lower level of comfortable temperatures, but most of those hours were during the night.

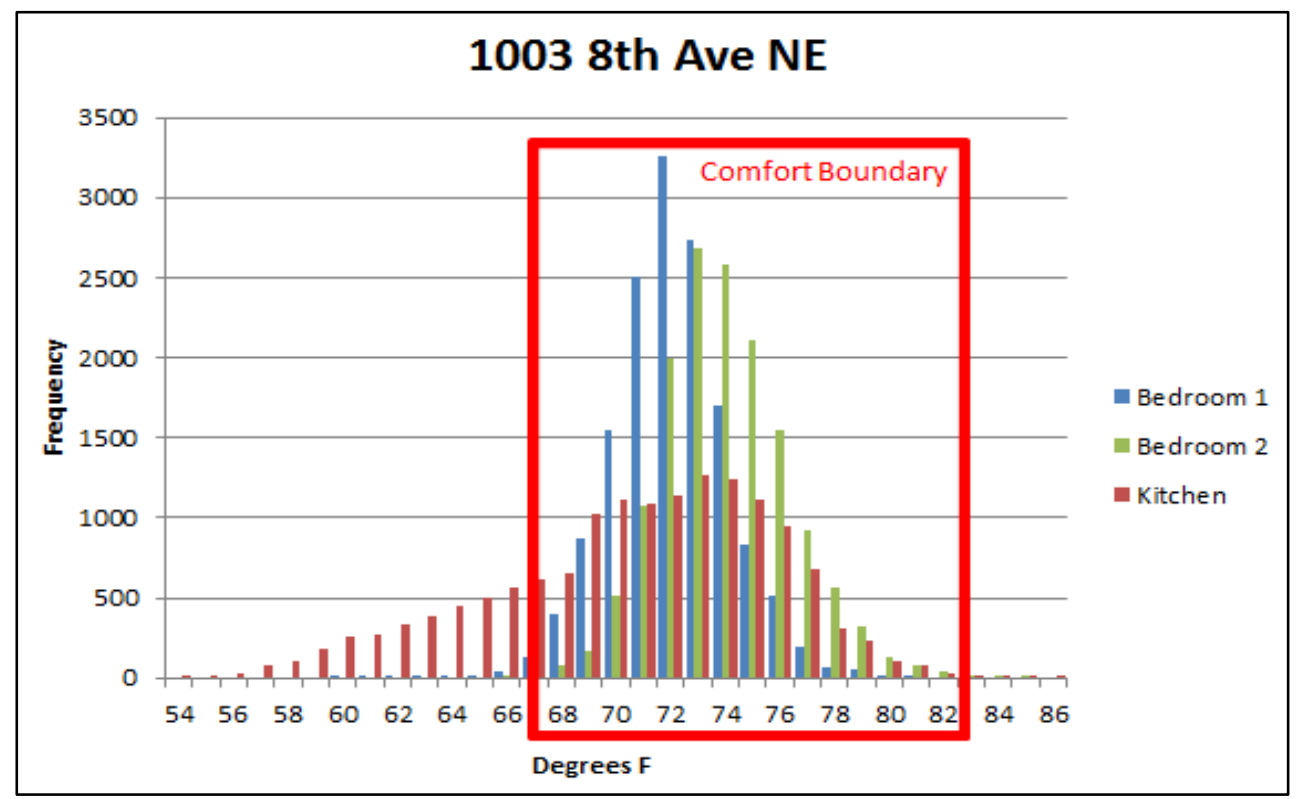

Figure 14. Living Home temperature and frequency 
The average, maximum, and minimum hourly electrical use was calculated for the period $3 / 28 / 2017$ to $7 / 19 / 2017$ to identify trends in the daily use patterns (Figure 15). The analysis shows average power for the house between 1,000 watts to 2,200 watts, indicating the residents are likely leaving a large percentage of the plug loads in the home energized throughout the day and shows that plug load control strategies are likely to help reduce the total electricity energy use.

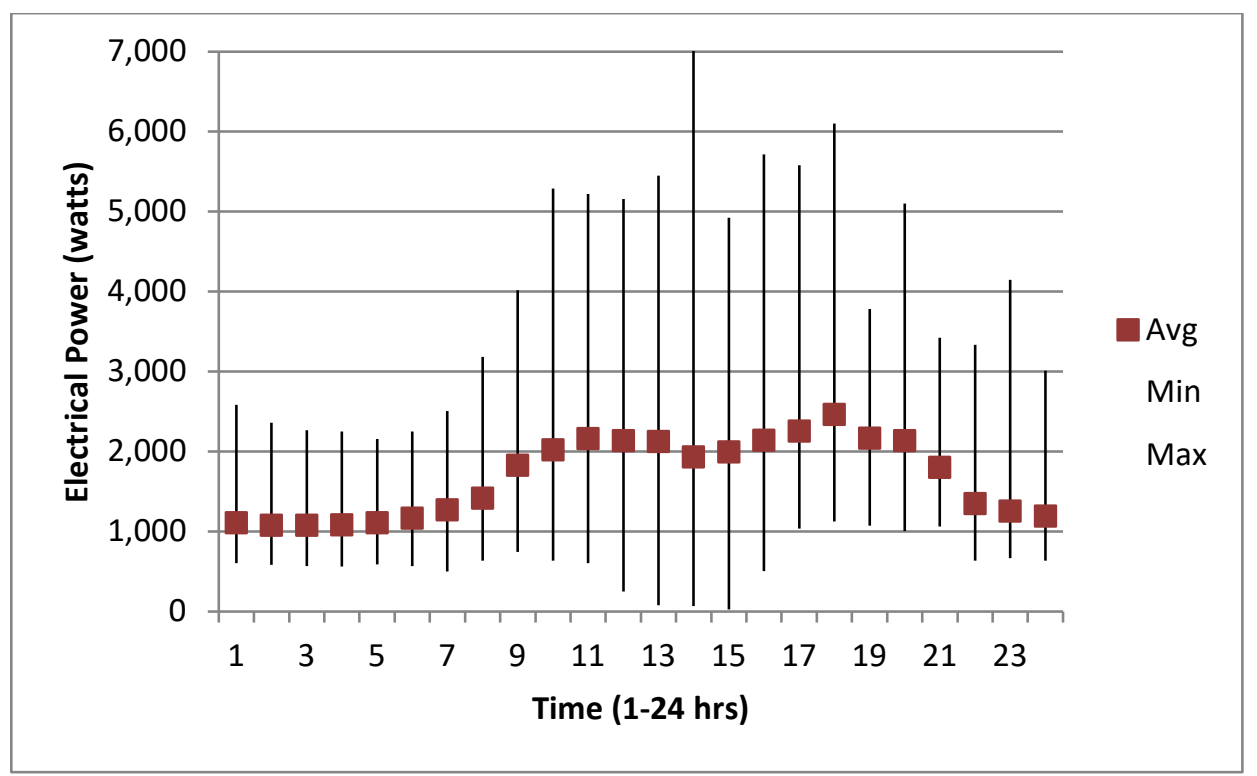

Figure 15. Living Home hourly energy use profile

\subsection{Existing Taxed II Credit Homes}

The Taxed II Credit home is a two-story, single-family home that was built by the Tribal Housing Authority as part of the housing stock for Poplar, Montana. The homes were built onsite in 2012. A graphical representation of the existing Taxed II Credit home as modeled in BEopt is provided in Figure 16.

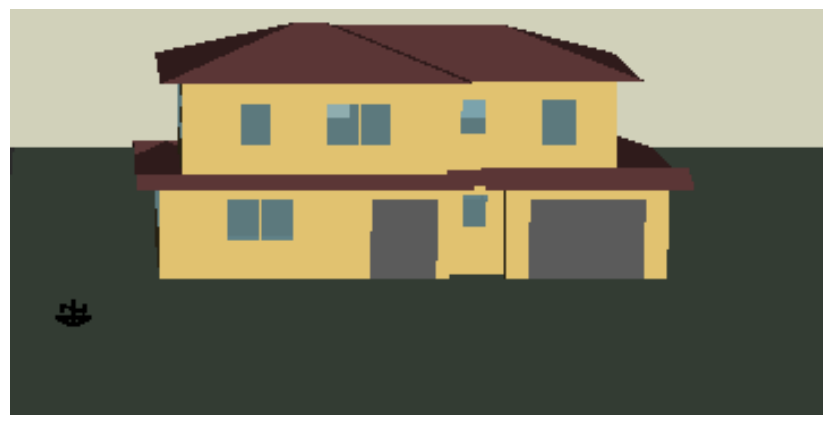

Figure 16. BEopt existing Taxed II Credit Home energy model rendering

The home utilizes a whole house fan for cooling in the summer and forced-air natural gas heating in the winter. The conditioned crawlspace is purposely heated and contains a sump pump to remove water as the water table is close to the surface. The general facility characteristics that were modeled in BEopt for the existing Taxed II Credit home are provided in Tables 6 and 7. 
Table 6. Existing Taxed II Credit Home BEopt Summary Information

\begin{tabular}{|c|c|c|}
\hline \multicolumn{3}{|c|}{ Taxed II Credit Home BEopt Model } \\
\hline Location & Weather File & USA_MT_WolfPoint \\
\hline \multirow{4}{*}{ Building } & Size $\left(\mathrm{ft}^{2}\right)$ & 1,650 \\
\hline & $\begin{array}{l}\text { Number of Bed / } \\
\text { Bath }\end{array}$ & $3 / 2$ \\
\hline & Orientation & North \\
\hline & Neighbors & Left;15 feet \\
\hline \multirow{3}{*}{ Walls } & Wood Stud & $\begin{array}{l}\text { R-19 fiberglass batt } 2 \times 616 " \text { on } \\
\text { center }\end{array}$ \\
\hline & Wall Sheathing & OSB \\
\hline & Exterior Finish & Wood siding/ Medium paint \\
\hline \multirow{2}{*}{ Ceiling/ Roof } & Roof & R-38 Cellulose, Vented \\
\hline & Roof Finish & Standing seam metal / light finish \\
\hline \multirow{2}{*}{ Foundation } & Slab / Crawlspace & $\begin{array}{c}\text { Unvented crawlspace with R-10 } \\
\text { Batts }\end{array}$ \\
\hline & Carpet & $0 \%$ carpet \\
\hline \multirow{4}{*}{ Windows and Doors } & Window Area & $282 \mathrm{ft}^{2}$ \\
\hline & Windows & $\begin{array}{c}\text { Low-E Double / non-metal (U value } \\
0.40, \text { SHGC 0.53) }\end{array}$ \\
\hline & Doors & Steel \\
\hline & Eaves & $2 \mathrm{ft}$ \\
\hline \multirow[b]{2}{*}{ Airflow } & Air leakage & $15 \mathrm{ACH} 50$ \\
\hline & $\begin{array}{l}\text { Mechanical } \\
\text { Ventilation }\end{array}$ & HRV,60\% \\
\hline \multirow{4}{*}{ Space Conditioning } & $\begin{array}{l}\text { Central Air } \\
\text { Conditioner }\end{array}$ & None \\
\hline & Furnace & Gas, $92.5 \%$ AFUE \\
\hline & Boiler & Condensing Gas, 96\% AFUE \\
\hline & Ducts & 7.5\% Leakage, Uninsulated \\
\hline
\end{tabular}


Table 7. Existing Taxed II Credit Home BEopt Summary Information \#2

\begin{tabular}{|c|c|c|}
\hline \multicolumn{3}{|c|}{ Taxed II Credit Home BEopt Model } \\
\hline $\begin{array}{l}\text { Space } \\
\text { Conditioning } \\
\text { Schedules }\end{array}$ & $\begin{array}{l}\text { Cooling Set } \\
\text { Point } \\
\text { Heating Set } \\
\text { Point }\end{array}$ & $\begin{array}{l}\text { None } \\
70 \text { F constant }\end{array}$ \\
\hline $\begin{array}{l}\text { Water } \\
\text { Heating }\end{array}$ & $\begin{array}{l}\text { Water Heater } \\
\text { Distribution }\end{array}$ & $\begin{array}{l}\text { Gas Standard, EF=0.56 } \\
\text { Uninsulated Copper }\end{array}$ \\
\hline Lighting & Lighting & $80 \%$ CFL \\
\hline Appliances & $\begin{array}{l}\text { Refrigerator } \\
\text { Cooking Range } \\
\text { Dishwasher } \\
\text { Clothes Washer } \\
\text { Clothes Dryer } \\
\text { Plug Loads } \\
\text { Domestic Hot } \\
\text { Water Use } \\
\text { Block heater }\end{array}$ & $\begin{array}{l}\text { Top Freezer } 18 \mathrm{ft}^{3} \\
\text { Electric } \\
\text { Standard } \\
\text { Standard } \\
\text { Electric } \\
\text { Default plug load use } \\
\text { Default use } \\
\text { External electrical load added to account for block } \\
\text { heaters }\end{array}$ \\
\hline
\end{tabular}

The total site energy use for the Existing Taxed II Credit Home is provided in Figure 17 and shows that heating and domestic hot water energy use are the two largest loads in the building with heating energy use making up $69.1 \%$ of the total and DHW energy use making up $13.2 \%$ of energy use, followed by plug load energy use (Misc E) making up $9 \%$ of the total energy use.

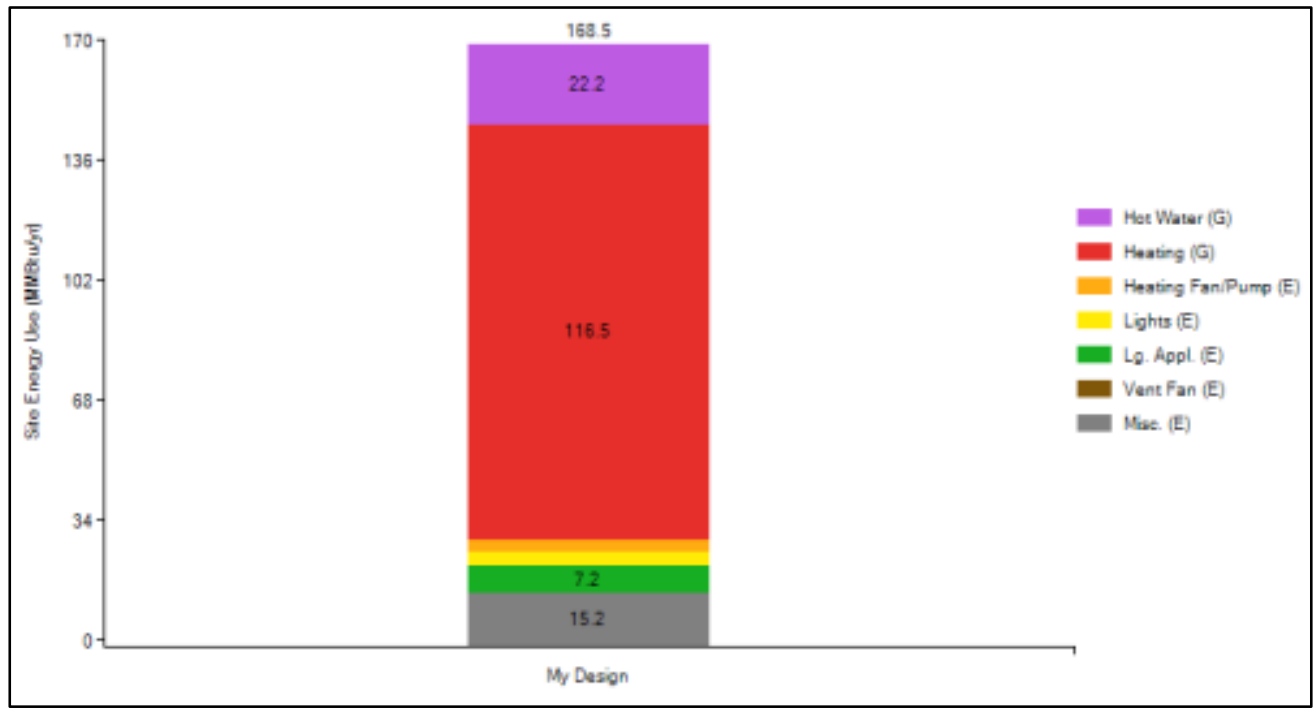

Figure 17. Existing Taxed II Credit home annual energy use by end use 
Temperature measurements were taken across five Taxed II Credit homes, and the temperature profiles were compared (Figure 18). Generally, the homes are able to maintain a comfortable temperature inside of the homes, although there are times when the home temperatures are outside the comfort region.

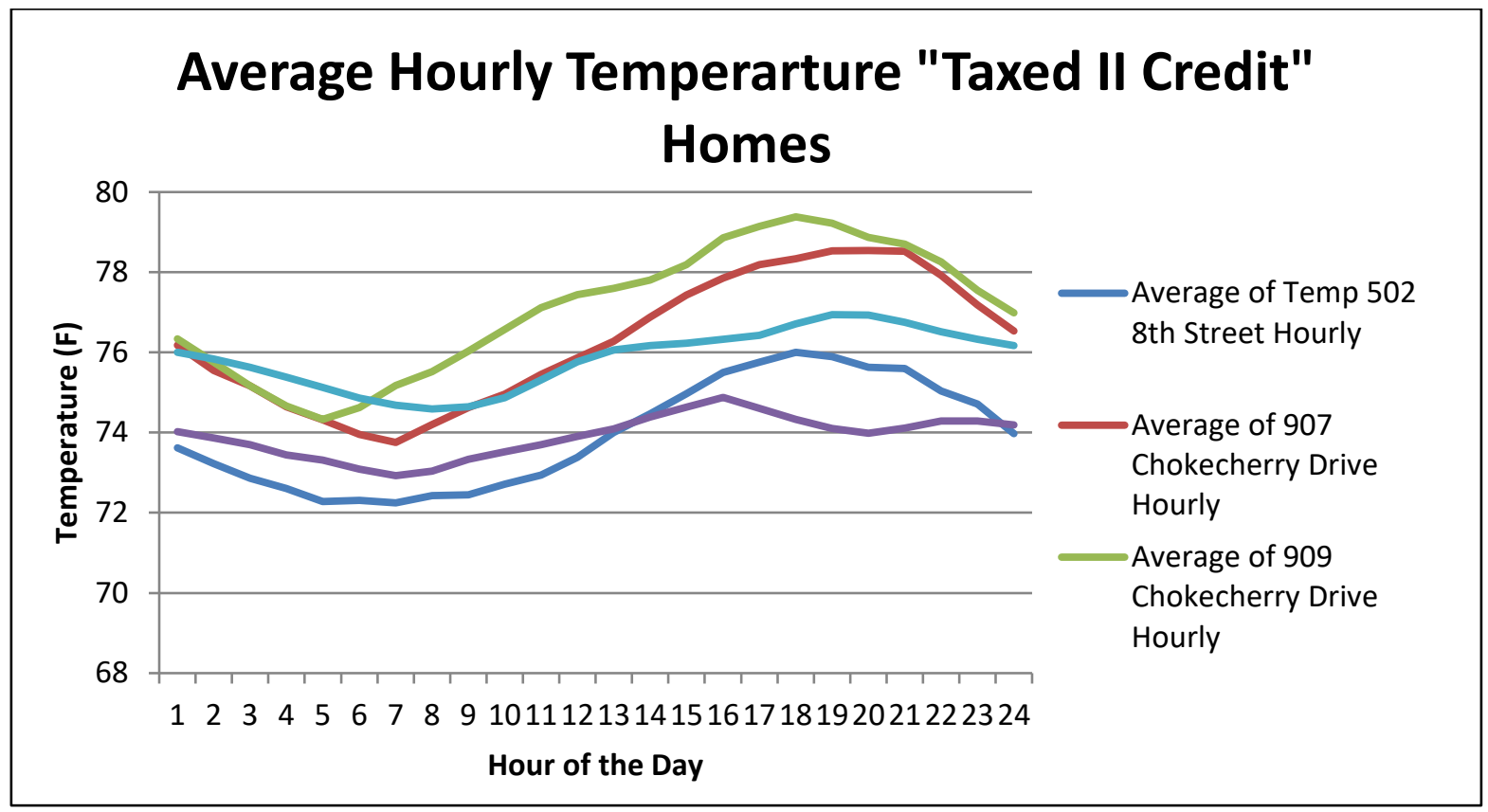

Figure 18. Metered temperature across Taxed II Credit homes

For the Taxed II Credit Homes, space temperatures were measured from 3/28/2017 - 8/30/2017. Averaging the temperature metered data across all the homes and spaces, the hours that the homes are outside of the comfortable range are summarized as:

- Below $67^{\circ} \mathrm{F}: 139$ hours/home

- Above $82^{\circ} \mathrm{F}: 293$ hours/home.

The average, maximum, and minimum hourly energy use was calculated for the period $3 / 28 / 2017$ to $7 / 19 / 2017$ to identify trends in the daily use patterns (Figure 19). The analysis shows a consistent baseload power for the house that averages 600 watts to 1,350 watts. 


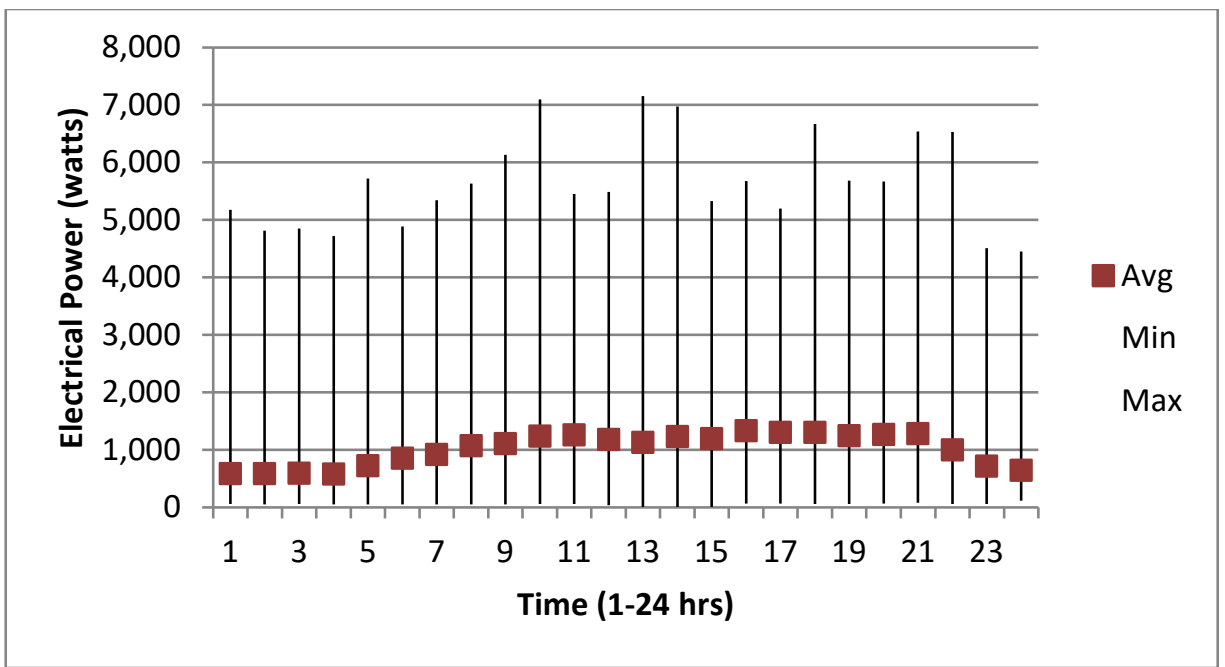

Figure 19. Taxed II Credit Home hourly energy use profile 


\section{Retrofit Energy Efficiency Measures}

The recommended measures for the homes have been broken into two categories: retrofit energyefficient measures and new construction energy-efficient measures. The reason that the measures are broken out as such, is because measures have much different capital costs depending on whether they are done during initial construction or after the building is already finished and occupied. When targeting low-energy housing, implementing the plan prior to construction and occupancy is almost always the more cost-effective strategy.

\subsection{Option House Energy-Efficiency Measures}

\subsubsection{Educate Home Owners on Thermostat Operation}

Current Condition: Based on the analysis of daily average outside air temperature and daily average interior space temperature, the thermostat set point was modeled as $70^{\circ} \mathrm{F}$ in cooling mode and $72^{\circ} \mathrm{F}$ in heating mode.

Recommended Action: Revise cooling set point temperature to $72^{\circ} \mathrm{F}$ and heating set point temperature to $70^{\circ} \mathrm{F}$.

\section{Energy Savings and Economics}

$\begin{array}{ll}\text { Electricity Savings } & 206 \mathrm{kWh} / \mathrm{yr} \\ \text { Natural Gas Savings } & 162.6 \text { therms } / \mathrm{yr} \\ \text { Cost Savings } & \$ 87 / \mathrm{yr} \\ \text { Installed Costs } & \$ 0 \\ \text { Simple Payback } & 0 \text { years }\end{array}$

Assumptions: The energy savings were modeled assuming the cooling set point was adjusted from $70^{\circ} \mathrm{F}$ to $72^{\circ} \mathrm{F}$ and the heating set point was adjusted from $72^{\circ} \mathrm{F}$ to $70^{\circ} \mathrm{F}$.

\subsubsection{Reduce Plug Load Energy Use with Wi-Fi Plug Load Wall Outlet}

Current Condition: The onsite electrical measurements showed a consistent baseload power that ranged from 800 watts to 2,100 watts during night time hours, indicating that a large percentage of the plug loads in the house is being left on when occupants are sleeping (Figure 20). 


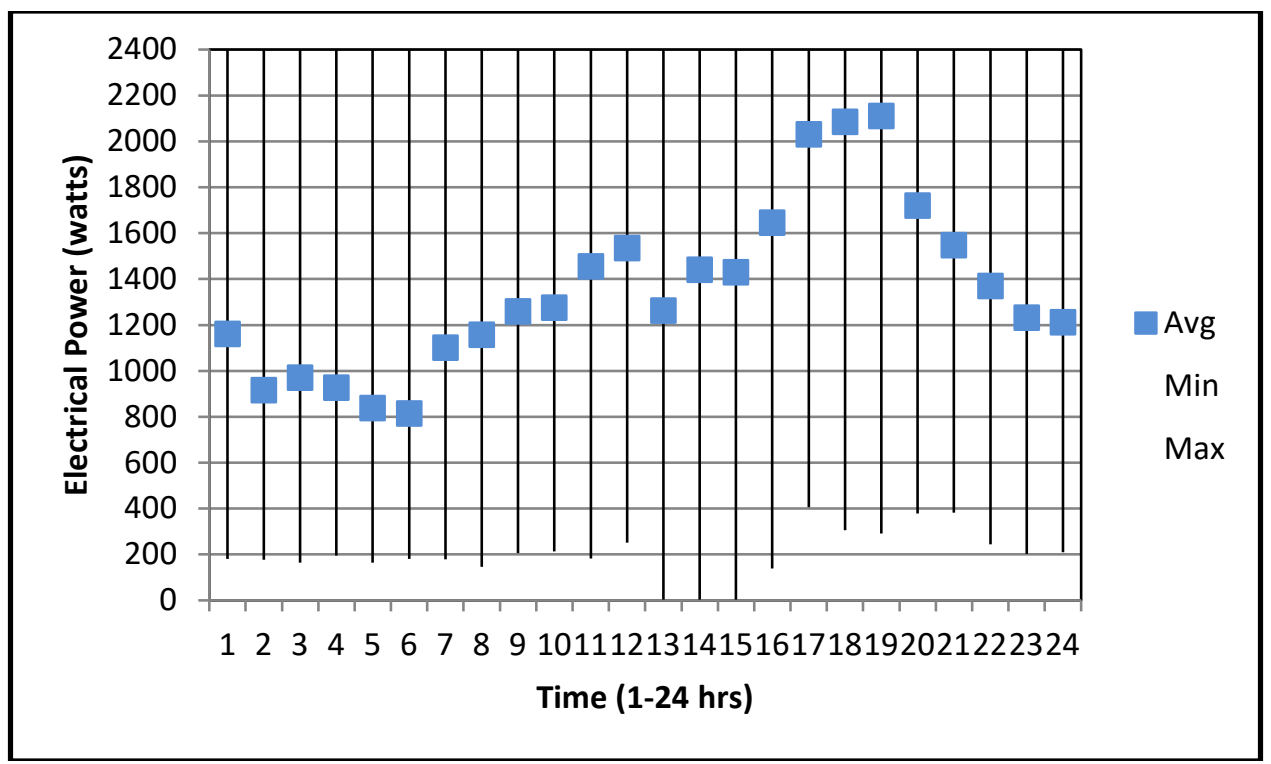

Figure 20. Option House hourly electricity use average daily load profile

Recommended Action: Install a Wi-Fi-enabled smart plug that can be used to turn off electrical sockets when the TVs, cable boxes, etc. are not in use. There are several vendors that sell these products. An example is the Belkin Wemo Insight Smart Plug.

In addition to controlling the devices, this product allows the homeowner to monitor energy use of electrical outlets, control plug load devices remotely, and schedule lights and appliances.

\section{Energy Savings and Economics}

$\begin{array}{ll}\text { Electricity Savings } & 1,114 \mathrm{kWh} / \mathrm{yr} \\ \text { Natural Gas Savings } & -25.6 \text { therms } / \mathrm{yr} \\ \text { Cost Savings } & \$ 63 / \mathrm{yr} \\ \text { Installed Costs } & \$ 120 \\ \text { Simple Payback } & 1.9 \text { years }\end{array}$

Assumptions: The energy savings were modeled assuming the plug load energy use dropped from $200 \%$ of the default baseline to $150 \%$ of the default baseline. The installed costs were calculated assuming four Wi-Fi enabled Smart Plugs were installed for \$30 apiece.

\subsubsection{Retrofit Interior CFL and Exterior Halogen Bulbs with LED Bulbs}

Current Condition: The current lighting consists of a mixture of 24 CFL and LED bulbs inside of the house with four exterior halogen bulbs.

Recommended Action: Replace interior CFL bulbs with LED bulbs and replace four exterior halogen bulbs with LED bulbs. 


\section{Energy Savings and Economics}

$\begin{array}{ll}\text { Electricity Savings } & 472 \mathrm{kWh} / \mathrm{yr} \\ \text { Natural Gas Savings } & -10.6 \text { therms/yr } \\ \text { Cost Savings } & \$ 27 / \mathrm{yr} \\ \text { Installed Costs } & \$ 140 \\ \text { Simple Payback } & 5.2 \text { years }\end{array}$

Assumptions: The modeled lighting was increased from 40\% LED / 60\% CFL to 100\% LED in the BEopt model. Installed costs were calculated assuming $\$ 40$ for the exterior LEDs and 10 interior LEDs at a cost of \$10/bulb.

\subsubsection{Relocate Water Lines to Underside of Insulation and Repair Insulation in Crawlspace}

Current Condition: Currently there are several places where the water lines are exposed to the vented crawlspace. The crawlspace ceiling (main level floor) is also poorly insulated. The existing R-38 batts are substantially degraded because they are misaligned and falling down in places. This results in cold floors and occupant discomfort.

Recommended Action: Relocate the water lines to the underside of the insulation so that they are tight against the floor and add heat tape to the waterline mains. Re-install and add additional insulation to the crawlspace.

\section{Energy Savings and Economics}

$\begin{array}{ll}\text { Electricity Savings } & -32 \mathrm{kWh} / \mathrm{yr} \\ \text { Natural Gas Savings } & 35.9 \text { therms/yr } \\ \text { Cost Savings } & \$ 14 / \mathrm{yr} \\ \text { Installed Costs } & \$ 1,600 \\ \text { Simple Payback } & 106.7 \text { years }\end{array}$

Assumptions: The crawlspace insulation was increased from an R-19 to an R-38 and the DHW PEX insulation value was increased to an R-2 in the BEopt model. Installed costs come from the onsite energy audit.

\subsection{Living House Energy-Efficient Measures}

\subsubsection{Educate Home Owners on Thermostat Operation}

Current Condition: All the new homes were equipped with programmable thermostats, but the thermostat programming did not appear to be utilized by many of the occupants. This could be because the homes are occupied most of the time or it could be because the occupants need additional training on how to operate the systems.

Recommended Action: Educate the occupants on how to fully utilize the thermostat or install self-programing thermostats that need limited interaction. 


\section{Energy Savings and Economics}

Electricity Savings

Natural Gas Savings

Cost Savings

Installed Costs

Simple Payback
$1,560 \mathrm{kWh} / \mathrm{yr}$

77.4 therms/yr

$\$ 184 / \mathrm{yr}$

$\$ 0$

0 years

Assumptions: The energy savings were calculated assuming that a programmable thermostat would reduce heating and cooling energy by $10 \%$.

\subsubsection{Reduce Plug Load Energy Use with Wi-Fi Plug Load Wall Outlet}

Current Condition: The onsite electrical measurements showed an average hourly power draw that ranged from 1,000 watts to 2,300 watts during, indicating that a large percentage of the plug loads in the house are being left on when occupants are sleeping (Figure 21).

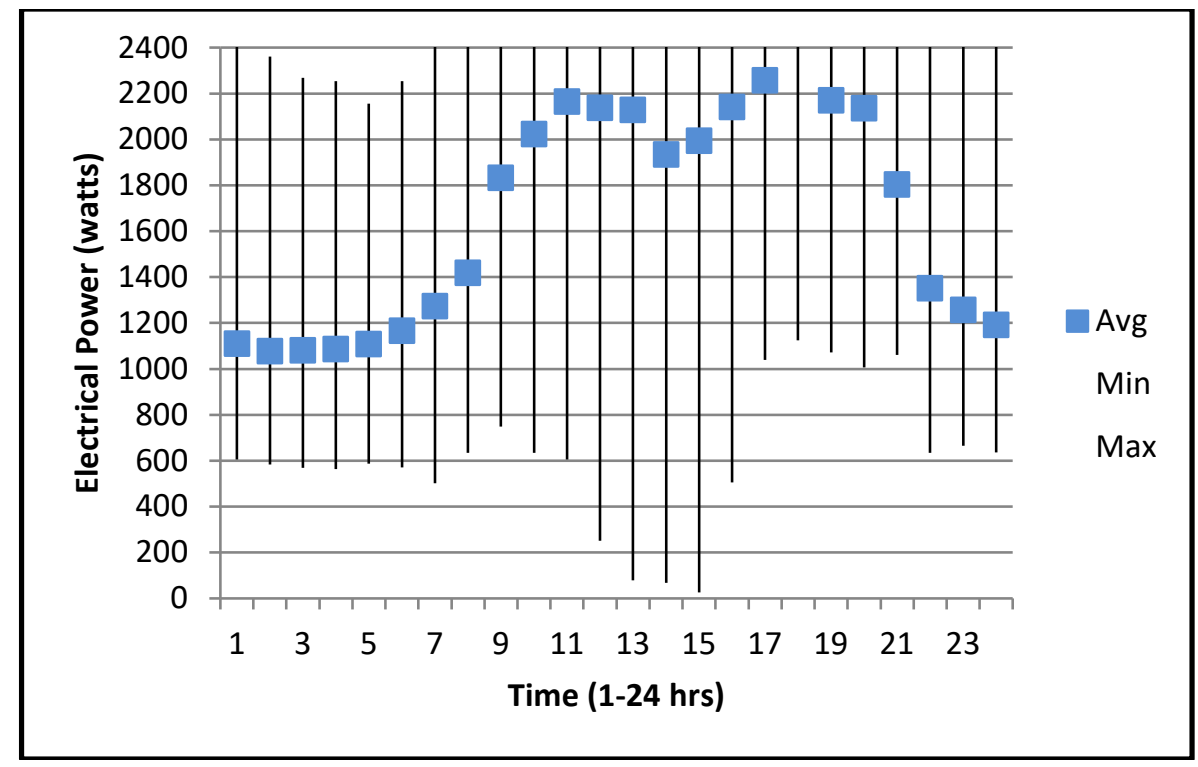

Figure 21. Living Home hourly electricity use average daily load profile

Recommended Action: Install a Wi-Fi-enabled Smart Plug that can be used to turn off electrical sockets when the TVs, cable boxes, etc. are not in use. There are several vendors that sell these products. An example is the Belkin Wemo Insight Smart Plug.

In addition to controlling the devices, this product allows the homeowner to monitor energy use of electrical outlets, control plug load devices remotely and schedule lights and appliances. 


\section{Energy Savings and Economics}

$\begin{array}{ll}\text { Electricity Savings } & 4,566 \mathrm{kWh} / \mathrm{yr} \\ \text { Natural Gas Savings } & -107.3 \mathrm{therms} / \mathrm{yr} \\ \text { Cost Savings } & \$ 323 / \mathrm{yr} \\ \text { Installed Costs } & \$ 240 \\ \text { Simple Payback } & 0.7 \text { year }\end{array}$

Assumptions: The energy savings were modeled assuming the plug load energy use dropped from $400 \%$ of the default baseline to $200 \%$ of the default baseline. The installed costs were calculated assuming eight Wi-Fi-enabled Smart Plugs were installed for \$30 apiece.

\subsubsection{Replace Interior CFL and Exterior Halogen Bulbs with LED Bulbs}

Current Condition: The current lighting consists of a mixture of 24 CFL and LED bulbs inside the house and four exterior halogen bulbs.

Recommended Action: Replace interior CFL bulbs with LED bulbs and replace four exterior halogen bulbs with LED bulbs.

\section{Energy Savings and Economics}

$\begin{array}{ll}\text { Electricity Savings } & 557 \mathrm{kWh} / \mathrm{yr} \\ \text { Natural Gas Savings } & -12.3 \text { therms/yr } \\ \text { Cost Savings } & \$ 40 / \mathrm{yr} \\ \text { Installed Costs } & \$ 140 \\ \text { Simple Payback } & 3.5 \text { years }\end{array}$

Assumptions: The modeled lighting was increased from 40\% LED / 60\% CFL to 100\% LED in the BEopt model. Installed costs were calculated assuming $\$ 40$ for the exterior LED bulbs, and 10 interior LED bulbs at a cost of $\$ 10 /$ bulb.

\subsubsection{Relocate Water Lines to Underside of Insulation and Repair Insulation in Crawlspace}

Current Condition: Currently there are several places where the water lines are exposed to the vented crawlspace. The crawlspace ceiling (main level floor) is also poorly insulated. The existing R-38 batts are substantially degraded because they are misaligned and falling down in places. This results in cold floors and occupant discomfort.

Recommended Action: Relocate the water lines to the underside of the insulation so that they are tight against the floor and add heat tape to the water line mains. Re-install and add additional insulation to the crawlspace 


\section{Energy Savings and Economics}

$\begin{array}{ll}\text { Electricity Savings } & -23 \mathrm{kWh} / \mathrm{yr} \\ \text { Natural Gas Savings } & 35.2 \text { therms/yr } \\ \text { Cost Savings } & \$ 20 / \mathrm{yr} \\ \text { Installed Costs } & \$ 1,000 \\ \text { Simple Payback } & 48 \text { years }\end{array}$

Assumptions: The crawlspace insulation was increased from an R-19 to an R-38, and the DHW PEX insulation value was increased to an R-2 in the BEopt model. Installed costs come from the onsite energy audit.

\subsubsection{Seal Air Leaks Throughout the Home}

Current Condition: During the energy audit, it was observed that the home had much higher infiltration than was expected. The blower door test revealed a reading of $4.81 \mathrm{ACH} 50$, which is nearly double the value of the other homes.

Recommended Action: Perform comprehensive air sealing throughout the entire envelope, the crawlspace, and rib joist.

\section{Energy Savings and Economics}

$\begin{array}{ll}\text { Electricity Savings } & -61 \mathrm{kWh} / \mathrm{yr} \\ \text { Natural Gas Savings } & 215.2 \text { therms } / \mathrm{yr} \\ \text { Cost Savings } & \$ 135 / \mathrm{yr} \\ \text { Installed Costs } & \$ 1,500 \\ \text { Simple Payback } & 11.1 \text { years }\end{array}$

Assumptions: The air infiltration in the space was reduced by two-thirds. Installed costs come from the onsite energy audit.

\subsection{Taxed II Credit Home Energy-Efficiency Measures \\ 6.3.1 Educate Home Owners on Thermostat Operation}

Current Condition: All the new homes were equipped with programmable thermostats, but the thermostats did not appear to be utilized by many of the occupants. This could be because the homes are occupied most of the time, or it could be because the occupants need additional training on how to operate the systems.

Recommended Action: Educate the occupants on how to fully utilize the thermostat or install self-programing thermostats that need limited interaction. 


\section{Energy Savings and Economics}

$\begin{array}{ll}\text { Electricity Savings } & 105.8 \mathrm{kWh} / \mathrm{yr} \\ \text { Natural Gas Savings } & 116.5 \text { therms } / \mathrm{yr} \\ \text { Cost Savings } & \$ 83 / \mathrm{yr} \\ \text { Installed Costs } & \$ 0 \\ \text { Simple Payback } & 0 \text { years }\end{array}$

Assumptions: The energy savings were calculated assuming that a programmable thermostat would reduce heating energy by $10 \%$.

\subsubsection{Seal Air Leaks Throughout the Hom}

Current Condition: During the energy audit, it was observed that the home had much higher infiltration than was expected. The blower door test revealed a reading of $14 \mathrm{ACH} 50$, which is nearly 7 times the value of the other homes.

Recommended Action: Perform comprehensive air sealing throughout the entire envelope, the crawlspace, and rib joist.

\section{Energy Savings and Economics}

$\begin{array}{ll}\text { Electricity Savings } & 495 \mathrm{kWh} / \mathrm{yr} \\ \text { Natural Gas Savings } & 545.1 \mathrm{therms} / \mathrm{yr} \\ \text { Cost Savings } & \$ 390 / \mathrm{yr} \\ \text { Installed Costs } & \$ 1,000 \\ \text { Simple Payback } & 2.6 \text { years }\end{array}$

Assumptions: The air infiltration in the space was reduced to $3 \mathrm{ACH} 50$. Installed costs come from the onsite energy audit.

\subsubsection{Retrofit Interior CFL and Exterior Halogen Bulbs with LED Bulbs}

Current Condition: The current lighting consists of a mixture of 42 CFL/LED bulbs and 6 incandescent bulbs inside the house.

Recommended Action: Replace interior CFL and incandescent bulbs with LED bulbs.

\section{Energy Savings and Economics}

$\begin{array}{ll}\text { Electricity Savings } & 281 \mathrm{kWh} / \mathrm{yr} \\ \text { Natural Gas Savings } & -7 \text { therms } / \mathrm{yr} \\ \text { Cost Savings } & \$ 21 / \mathrm{yr} \\ \text { Installed Costs } & \$ 200 \\ \text { Simple Payback } & 9.5 \text { years }\end{array}$

Assumptions: The modeled lighting was increased from $80 \%$ CFL to $100 \%$ LED in the BEopt model. Installed costs were calculated assuming $\$ 5 /$ bulb for the 40 interior LEDs. 


\subsubsection{Reduce Plug Load Energy Use with Wi-Fi Plug Load Wall Outlet}

Current Condition: The onsite electrical measurements showed an average hourly power draw that ranged from 600 watts to 1,350 watts throughout the course of the day, indicating that while not large, a significant percentage of the plug loads in the house are being left on when occupants are sleeping (Figure 22).

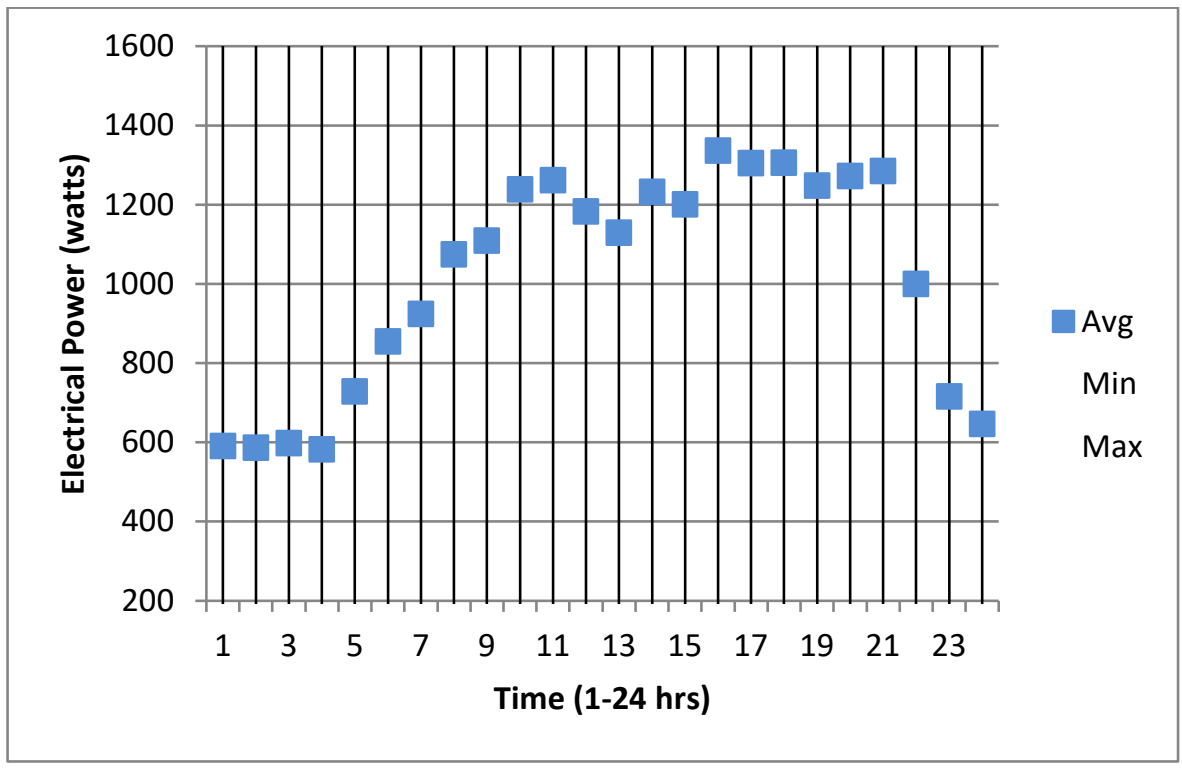

Figure 22. Living Home hourly electricity use average daily load profile

Recommended Action: Install a Wi-Fi-enabled Smart Plug that can be used to turn off electrical sockets when the TVs, cable boxes, etc., are not in use. There are several vendors that sell these products. An example is the Belkin Wemo Insight Smart Plug.

In addition to controlling the devices, this product allows the homeowner to monitor energy use of electrical outlets, control plug load devices remotely, and schedule lights and appliances.

\section{Energy Savings and Economics}

Electricity Savings

Natural Gas Savings

Cost Savings

Installed Costs

Simple Payback
$551 \mathrm{kWh} / \mathrm{yr}$

-14 therms/yr

$\$ 41 / \mathrm{yr}$

$\$ 120$

2.9 years

Assumptions: The energy savings were modeled assuming the plug load energy use dropped from $125 \%$ of the default baseline to the default baseline. The installed costs were calculated assuming four Wi-Fi-enabled Smart Plugs were installed for $\$ 30$ apiece.

\subsubsection{Add Ceiling Insulation}

Current Condition: Currently there are several places where the attic insulation is poor or missing or has air gaps. This results in cold floors and occupant discomfort. 
Recommended Action: Add additional insulation to the attic.

\section{Energy Savings and Economics}

Electricity Savings

Natural Gas Savings

Cost Savings

Installed Costs

Simple Payback
$14 \mathrm{kWh} / \mathrm{yr}$

16 therms/yr

$\$ 11.50 / \mathrm{yr}$

$\$ 800$

70 years

Assumptions: The attic insulation was increased from an R-30 to R-60 Cellulose, Gr-1, Vented in the BEopt model. Installed costs come from the onsite energy audit.

\subsubsection{Install ENERGY STAR-Rated Appliances (Dishwasher, Clothes Washer, Clothes Dryer, Refrigerator)}

Current Condition: Currently, based on the onsite energy audit report, there are no ENERGY STAR-rated appliances in the house.

Recommended Action: When the appliances are due to be replaced, replace the units with an ENERGY STAR-rated with the same size capacity.

\section{Energy Savings and Economics}

$\begin{array}{ll}\text { Electricity Savings } & 740 \mathrm{kWh} / \mathrm{yr} \\ \text { Natural Gas Savings } & 26 \text { therms/yr } \\ \text { Cost Savings } & \$ 83 / \mathrm{yr} \\ \text { Installed Costs } & \$ 2,650 \\ \text { Simple Payback } & 31 \text { years }\end{array}$

Assumptions: Installed costs were assumed to be: refrigerator $\$ 750$, clothes dryer $\$ 700$, clothes washer $\$ 700$, and dishwasher $\$ 500$. 


\section{New Construction Recommendations}

To verify that the homes were designed for minimum life-cycle cost in this climate, the team ran parametric new construction models with a combination of different design conditions. The BEopt model has the ability to evaluate hundreds of different combinations of design conditions, running a model for each iteration, and then calculating the lifecycle cost. See Figure 23.

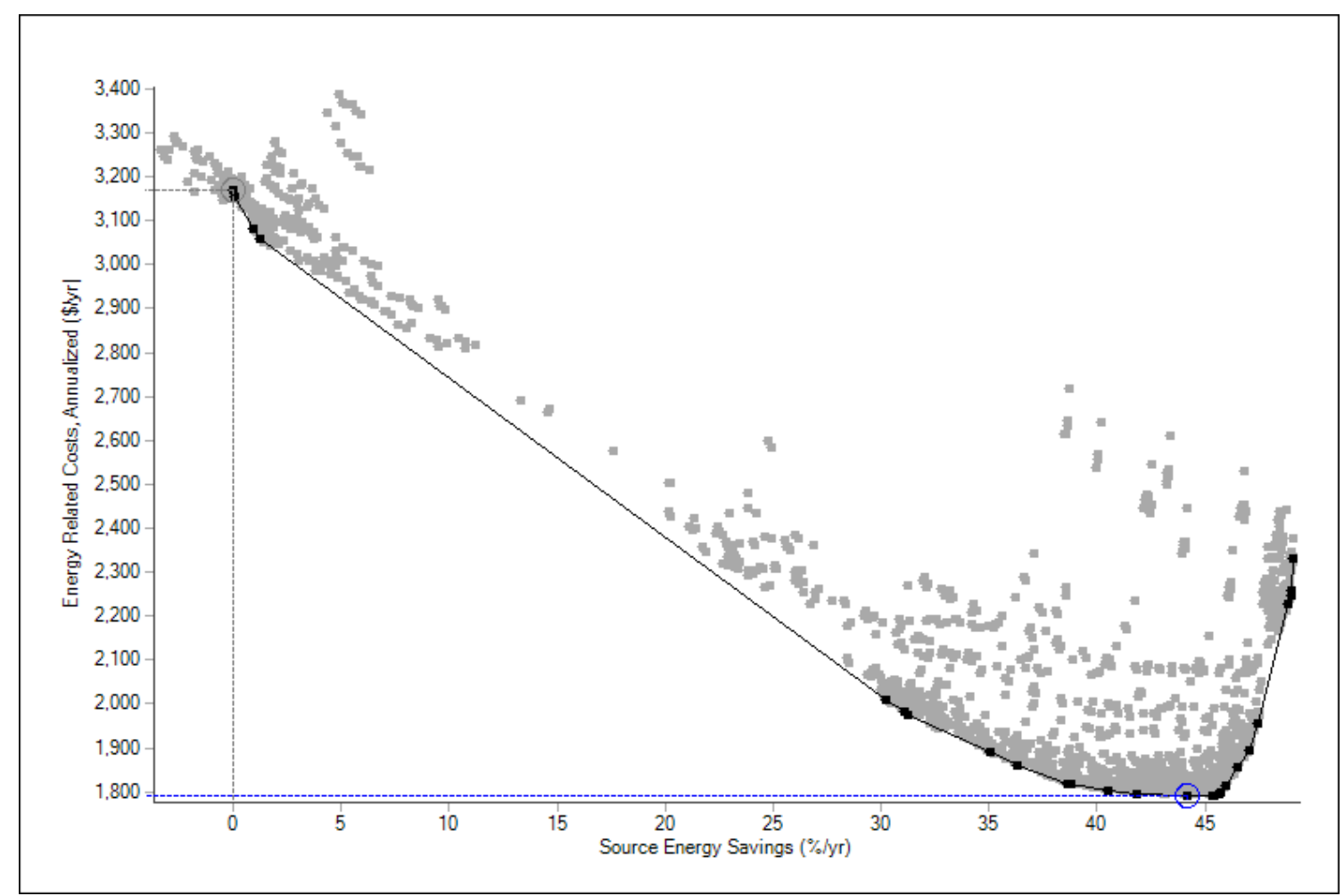

Figure 23. Building configuration design options: energy costs vs. energy savings

Once all the combinations are simulated, the simulation with the lowest life-cycle cost is selected with a listing of the building insulation levels, interior equipment, windows, doors, appliances, and other structure designs. For each of the recommended changes from the baseline design (calibrated model of the existing home), there is a cost associated with the recommendation. Figure 24 shows an example of how the outputs are displayed. 


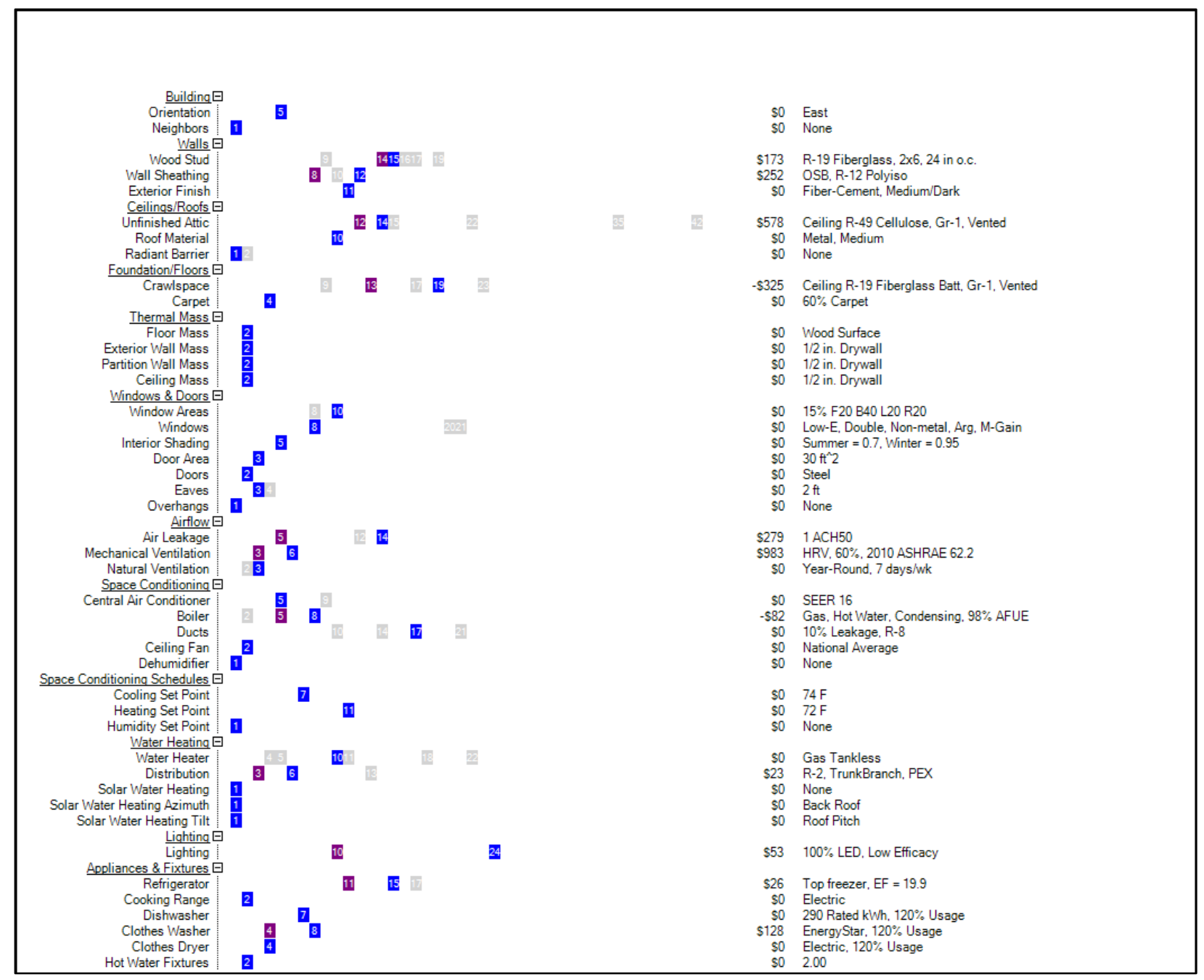

Figure 24. Selected design options with lowest life-cycle cost

The analysis was performed for each of the study homes. Generally, the MIRF homes were well designed for the climate and integrated most of the measures that were determined to be lifecycle cost effective. Similarly, the Taxed II Credit homes were well designed and, if properly constructed, have the potential to be very efficient. The specific findings for each style of housing unit are described in the following sections.

\subsection{Option House New Construction Measures}

For the Option House, an optimization was performed that looked at the impact of changing the wall construction from $2 \times 616$ in. on center to $2 \times 624$ in. on center, three different wall sheathing insulation options, two different crawlspace insulation options, three different window type options, two different mechanical ventilation options, three different DHW distribution options, four different lighting options, and two different plug load energy use options. A full list of the optimization variables that were included in the BEopt optimization is provided below: 


\section{Wood Stud}

- $2 \times 616 "$ on center w/fiberglass batts

- $2 \times 624$ " on center w/fiberglass batts

\section{Wall Sheathing}

- R-4 sheathing (based on Option House)

- R-5 XPS

- R-10 XPS

\section{Crawlspace}

- R-19 fiberglass batts, vented

- R-30 fiberglass batts vented

\section{Windows}

- Low E Double, Non-Metal, L gain (U 0.37, Solar Heat Gain Coefficient (SHGC) 0.3)

- Low E Double, Insulated, H gain Argon (U 0.29, SHGC 0.56)

- Low E Triple, Insulated, Arg H gain (U 0.18, SHGC 0.4)

\section{Mechanical Ventilation}

- Exhaust Standard ASHRAE 62.2

- ERV, 72\% mechanical ventilation

\section{DHW Distribution}

- Uninsulated, Trunkbranch PEX

- R-2, Trunkbranch, PEX

- R-5, Trunkbranch, PEX, Timer

\section{Lighting}

- $40 \%$ LED

- $80 \%$ LED

- $100 \%$ LED

- $100 \%$ LED low efficiency

\section{Plug Loads}

- $150 \%$

- $200 \%$

The solution set that was selected resulted in a site energy savings of around $16.3 \%$ at an annualized energy cost below the current baseline home. 


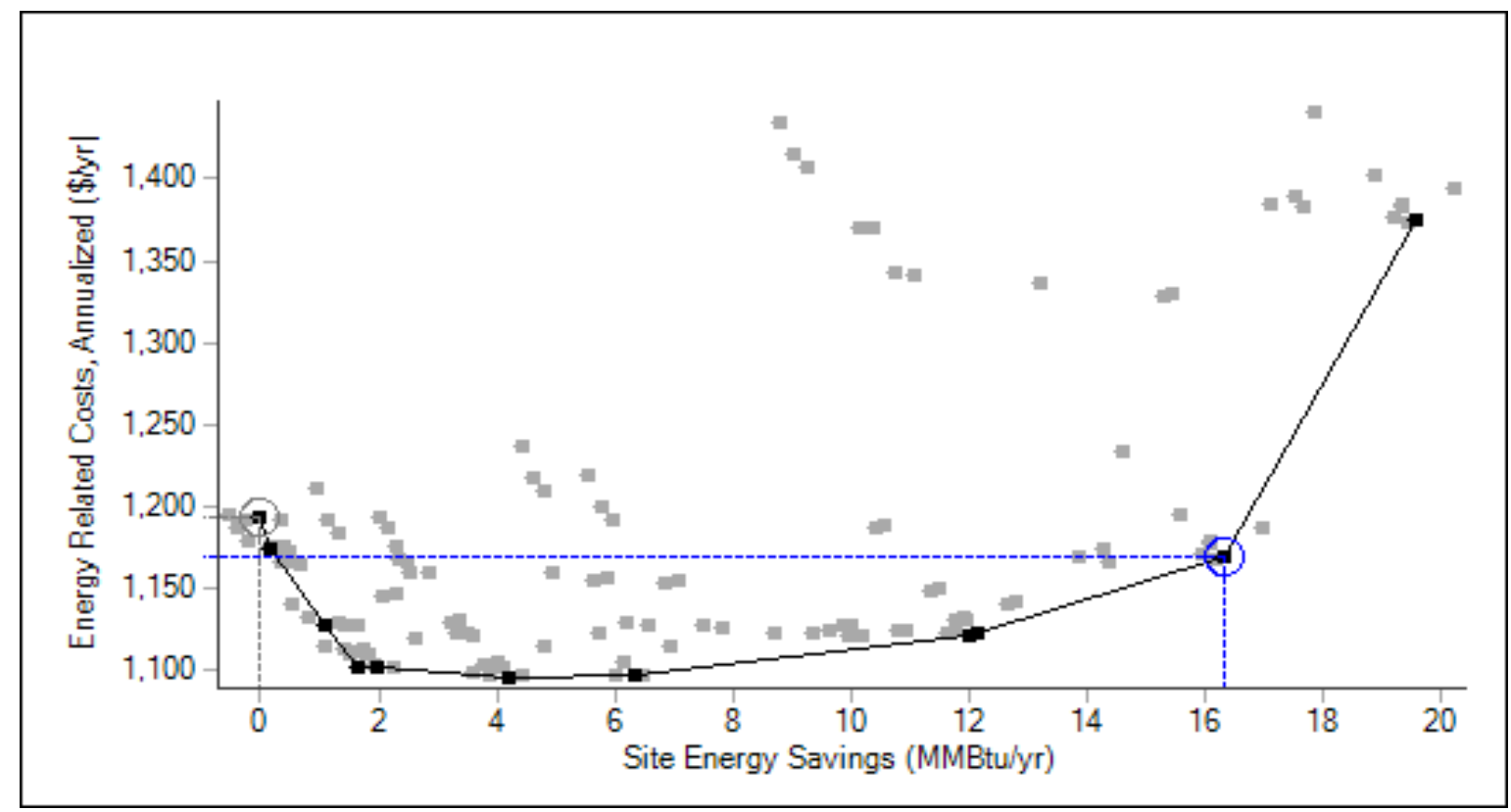

Figure 25. Option House new construction optimization curve

To achieve $16.3 \%$ energy savings, the following design and operational changes are recommended:

- Modify wall construction to $2 \times 624$ " on center to increase wall R value and increase the wall sheathing to an R-10 XPS.

- Increase the crawlspace insulation to R-30 fiberglass batts with a vented crawlspace and an R-2 insulation to the PEX DHW distribution system.

- Install an ERV with a $72 \%$ efficiency versus the standard mechanical ventilation system. In homes with very low air leakage like the Option House, this is an important design change to ensure sufficient ventilation air within the home.

- Increase the percentage of LED lighting to $100 \%$.

- Reduce the plug load energy use from $200 \%$ of the standard baseline assumption to $150 \%$ of the standard baseline assumption using Wi-Fi-based plug load controls.

\subsection{Living House Energy-Efficiency Measures}

The Living Home, as designed, was well thought out and incorporated many design features that would result in an efficient home for this climate. A full list of the optimization variables that were included in the BEopt optimization are provided below: 


\section{Wood Stud}

- 2x4 16" on center w/ R-13 fiberglass batts

- 2x4 16" on center w/ R-23 closed cell spray foam

- 2x6 24" on center w/ R-36 closed cell spray foam

- 2 x6 24" on center w/ R-20 open cell spray foam

- 2x6 24" on center w/ R-19 fiberglass batts

- 2x6 24" on center w/ R-21 fiberglass batts

\section{Ceiling}

- Insulation level R-49

\section{Wall Sheathing}

- R-5 XPS

- R-12 Polyiso

- $\mathrm{R}-10$ XPS

\section{Radiant Barrier}

- None

- Double Sided Foil

\section{Crawlspace}

- R-18 Polyiso, Unvented

- R-21 fiberglass Batt, Unvented

- R-19 Open Cell Spray Foam, Unvented

- R-19 fiberglass Batt, Vented

- R-30 Closed Cell Spray Foam, Vented

- Low E Double, Nonmetal, M gain

- Low E Triple, Insulated, H gain Air

- Low E Triple, Insulated, L gain Air

\section{Eaves}

- $2 \mathrm{ft}$

- $3 \mathrm{ft}$

\section{Air Leakage}

- $10 \mathrm{ACH} 50$

- $3 \mathrm{ACH} 50$

- $1 \mathrm{ACH} 50$ 


\section{Mechanical Ventilation}

- Exhaust Standard ASHRAE 62.2

- ERV, 72\% Efficient

\section{Natural Ventilation}

- 3 days/week

- 7 days/week

\section{Air Conditioner}

- SEER 16

- SEER 21

\section{Boiler}

- Electric Hot Water

- Gas Forced Draft (85\%)

- Gas Condensing (98\%)

\section{Ducts}

- $15 \%$ Leakage, Uninsulated

- $10 \%$ Leakage, Uninsulated

- $10 \%$ Leakage, R-8

- $\quad 7.5 \%$ Leakage, R-8

\section{Water Heater}

- Electric Premium

- Electric Tankless

- Gas Tankless

- Gas Tankless, Condensing

- Heat Pump Water Heater 50 gal

- Heat Pump Water Heater 80 gal

\section{DHW Distribution}

- Uninsulated, Trunkbranch PEX

- R-2, Trunkbranch, PEX

- R-5, Trunkbranch, PEX, Timer 


\section{Appliances}

- $\quad$ Top Freezer, $\mathrm{EF}=15.9$

- $\quad$ Top Freezer, EF = 19.9

- $\quad$ Top Freezer, $\mathrm{EF}=21.9$

\section{Lighting}

- $40 \%$ LED, $34 \%$ CFL

- $100 \%$ LED low efficacy

Of the 51 different categories of measures that were evaluated, only eight design changes are recommended.

- Increase the level of insulation in the ceiling to a level of R-49.

- Modify wall construction to $2 \times 624$ " on center to increase wall R value and increase the wall sheathing to an R-10 XPS.

- Increase the crawlspace insulation to R-30 fiberglass batts with a vented crawlspace and an R-2 insulation to the PEX DHW distribution system.

- Install an ERV with a $72 \%$ efficiency versus the standard mechanical ventilation system. In homes with very low air leakage like the Option House, this is an important design change to ensure sufficient ventilation air within the home.

- Increase the percentage of LED lighting to $100 \%$.

- $\quad$ Reduce the plug load energy use using Wi-Fi-based plug load controls.

- Increase the insulation on the ducts to R-8.

- Limit infiltration to $1 \mathrm{ACH} 50$, and perform a blower door test to verify.

Implementing these measures would improve the energy performance of the home by $11 \%$. Figure 26 shows the breakdown of energy use before and after the optimal efficiency measures are implemented. 


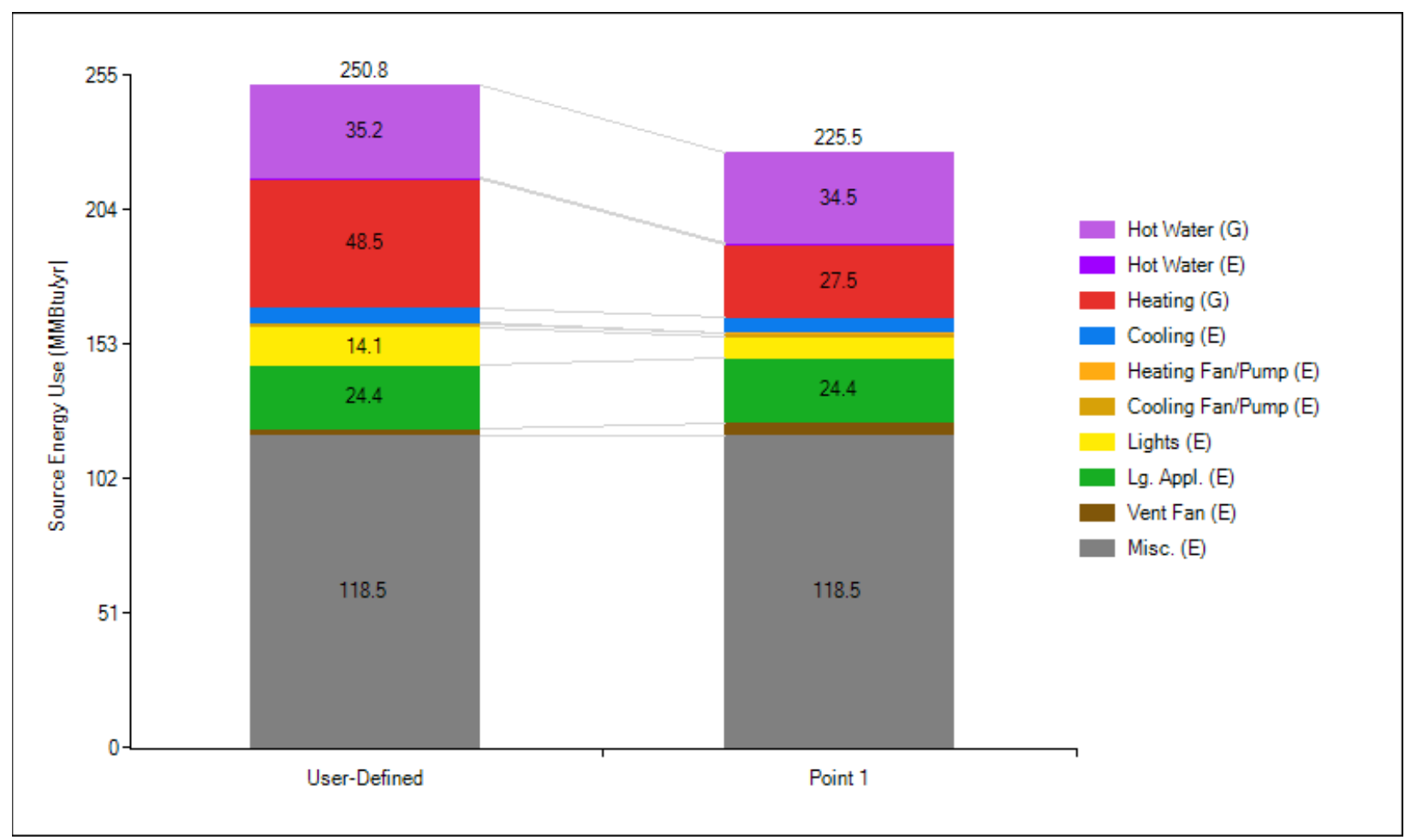

Figure 26. Baseline home energy use compared to minimum life-cycle cost design

These efficiency measures would not substantially increase the cost of the home, only adding $\$ 3,600$ to the total construction cost. The savings over the life of the home would pay for that many times over.

\subsection{Existing Taxed II Credit Home New Construction Measures}

For the existing Taxed II Credit home, an optimization was performed that looked at the impact of changing the wall construction, three different wall sheathing insulation options, four different attic insulation options, four different crawlspace insulation options, four different window type options, four different air leakage options, two different mechanical ventilation options, two different types of central air conditioner, three different DHW distribution options, two different clothes washer options, three different options of refrigerator, two different dishwasher options, and three different DHW options. A full list of the optimization variables that were included in the BEopt optimization are:

\section{Wood Stud}

- $2 \times 624$ " on center R-19 fiberglass batts

- $2 \times 624$ " on center R-21 fiberglass batts

- $2 \times 624 "$ on center R-19 fiberglass

- 2x6 24" on center R-36 closed cell spray foam

\section{Wall Sheathing}

- R-5 XPS, OSB

- $\mathrm{R}-15 \mathrm{XPS}, \mathrm{OSB}$ 


\section{Unfinished Attic}

- Ceiling R-60 Cellulose, Gr-1, Vented

- Ceiling R-49 Cellulose, Gr-1, Vented

- Ceiling R-60 Closed cell spray foam, Gr-1, Vented

- Roof R-47,5 SIP, Unvented

\section{Crawlspace}

- Wall R-21 fiberglass batts, Unvented

- Wall R-19 Open cell spray foam

- Ceiling R-19 fiberglass batts, Gr-1, Vented

- Ceiling R-30 Closed Cell Spray Foam, Gr-1, Vented

\section{Windows}

- Low E Double, Nonmetal, L gain (U 0.37, SHGC 0.3)

- Low E Double, Nonmetal, M gain (U 0.35, SHGC 0.44)

- Low E Triple, Insulated, Air, L gain (U 0.19, SHGC 0.27)

- Low E Triple, Insulated, Arg, H gain (U 0.18, SHGC 0.4)

\section{Air Leakage}

- $15 \mathrm{ACH} 50$

- $10 \mathrm{ACH} 50$

- $3 \mathrm{AC} 50$

- $1 \mathrm{AC} 50$

\section{Mechanical Ventilation}

- Exhaust Standard ASHRAE 62.2

- $\mathrm{HRV}, 60 \%$ mechanical ventilation

\section{Central Air Conditioner}

- SEER 16

- $\quad$ SEER 21

\section{Ducts}

- $10 \%$ Leakage, R-8

- $7.5 \%$ Leakage, Uninsulated

- $\quad 7.5 \%$ Leakage, R-8 


\section{DHW}

- $\quad$ Gas Standard $(\mathrm{EF}=0.56)$

- Gas Tank Condensing $(\mathrm{EF}=0.96)$

- Heat Pump Water Heater, 50 gallons $(\mathrm{EF}=2.35)$

\section{DHW Distribution}

- Uninsulated, Trunkbranch, PEX

- R-2, Trunkbranch, PEX

- R-5, Trunkbranch, PEX, Timer

\section{Refrigerator}

- $\quad$ Top freezer, $\mathrm{EF}=15.9$

- $\quad$ Top freezer, $\mathrm{EF}=19.9$

- $\quad$ Top freezer, $\mathrm{EF}=21.9$

\section{Dishwasher}

- 318 rated $\mathrm{kWh}$

- 290 rated $\mathrm{kWh}, 120 \%$ Use

\section{Clothes Washer}

- Standard, $120 \%$ Use

- ENERGY STAR, 120\% Use 
The solution set that was selected based on minimum cost resulted in a site energy savings of around $27 \%$ at an annualized energy cost below the current baseline home.

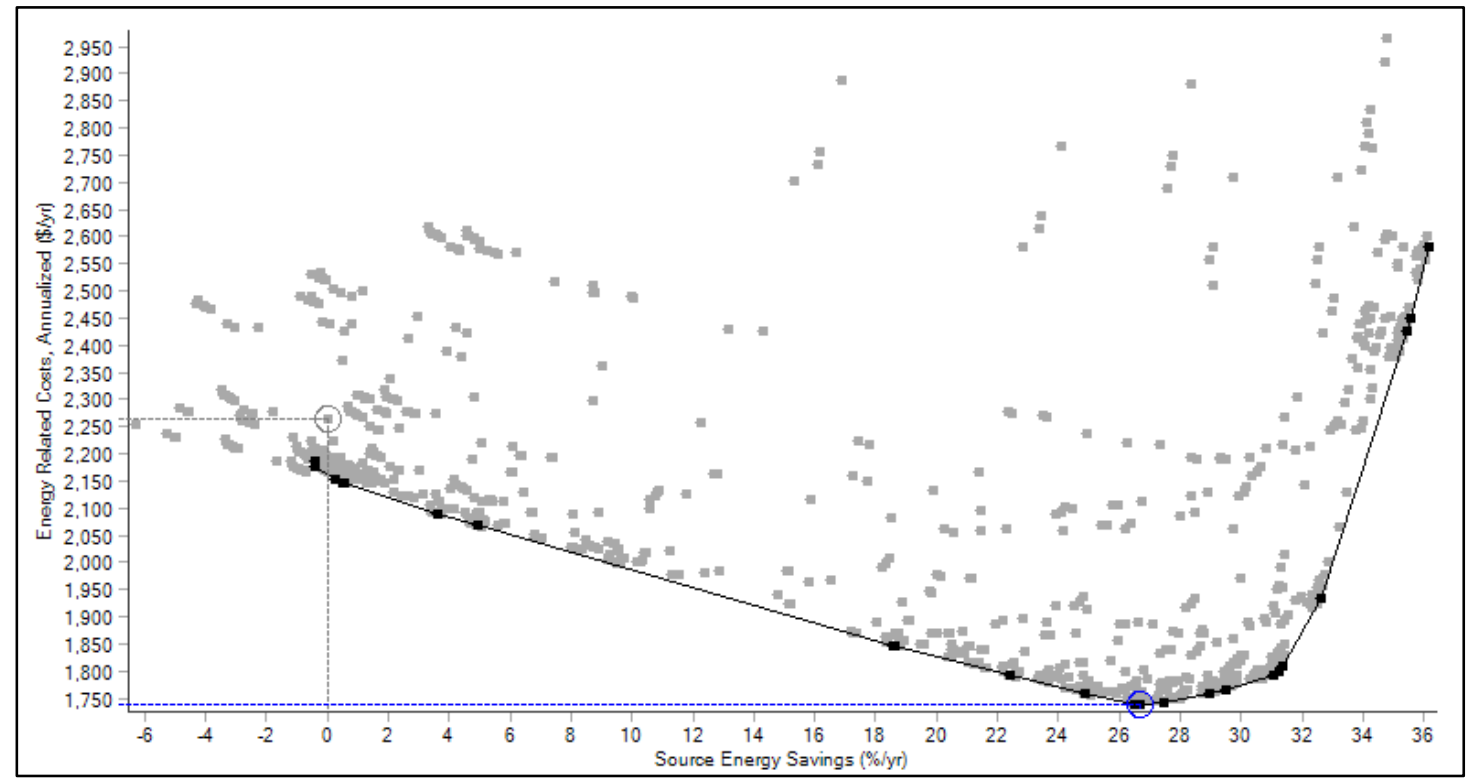

Figure 27. Exiting Taxed II Credit Home new construction optimization curve

To achieve $27 \%$ energy savings, the following design and operational changes are recommended are as follow:

- Modify wall construction to $2 \times 624$ " on center R-19 fiberglass to increase wall R value, and increase the wall sheathing to an R-5 XPS, OSB

- Increase the level of insulation in the ceiling to R-60 Cellulose, Gr-1, Vented

- Increase the crawlspace insulation to a R-21 fiberglass batt with unvented crawlspace, and an R-2 insulation to the PEX DHW distribution system

- Increase the percentage of LED lighting to $100 \%$

- Reduce the plug load energy use using Wi-Fi-based plug load controls

- Limit infiltration to $1 \mathrm{ACH} 50$, and perform a blower door test to verify

- Modify windows to Low E Double, Nonmetal, M gain (U 0.35, SHGC 0.44)

- Increase the insulation on the ducts to R-8

- Change all the appliances to ENERGY STAR rated. 


\section{Renewable Energy Analysis}

Photovoltaics are semiconductor devices that convert sunlight directly into electricity. They do so without any moving parts and without generating any noise or pollution. They must be mounted in an unshaded location; rooftops, carports, and ground-mounted arrays are common mounting locations. Under full sun, each square meter of PV area produces about 100 watts of direct current electricity, though this efficiency depends on the type of collector, the tilt and azimuth of the collector, the ambient temperature, and the level of sunlight. An inverter is required to convert the direct current to alternating current of the desired voltage compatible with building and utility power systems. The balance of the system consists of conductors/conduit, switches, disconnects, and fuses. Grid-connected PV systems feed power into the facility's electrical system and do not include batteries. Figure 28 shows the major components of a gridconnected PV system and illustrates how these components are interconnected.

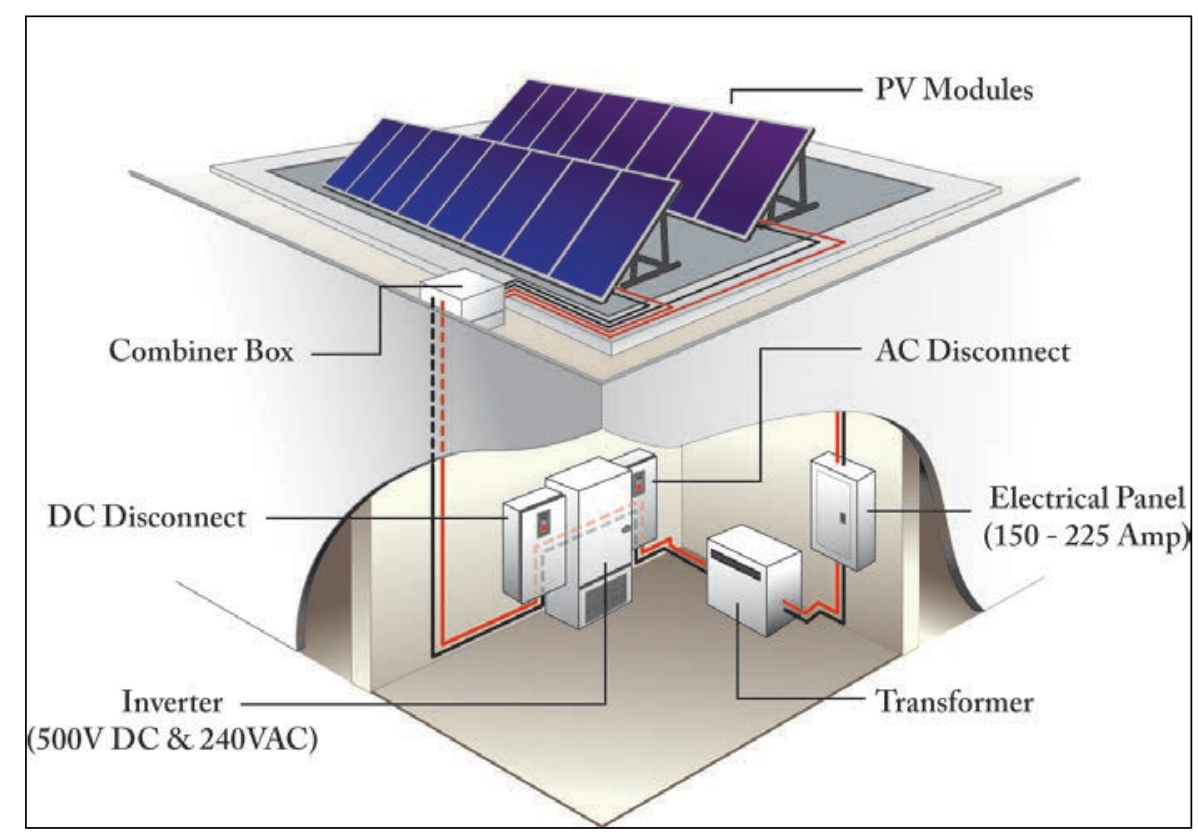

Figure 28. Depiction of major components of grid-connected PV system

Recommended Action: Install a roof-mounted PV system on all three existing homes analyzed in this study. An Aurora Solar shading analysis was conducted for $124 \mathrm{C} \mathrm{St} \mathrm{East}$ Poplar, Montana, which showed that a 13.34-kW PV system could be installed on the southfacing roof of this residence (Figure 29). 


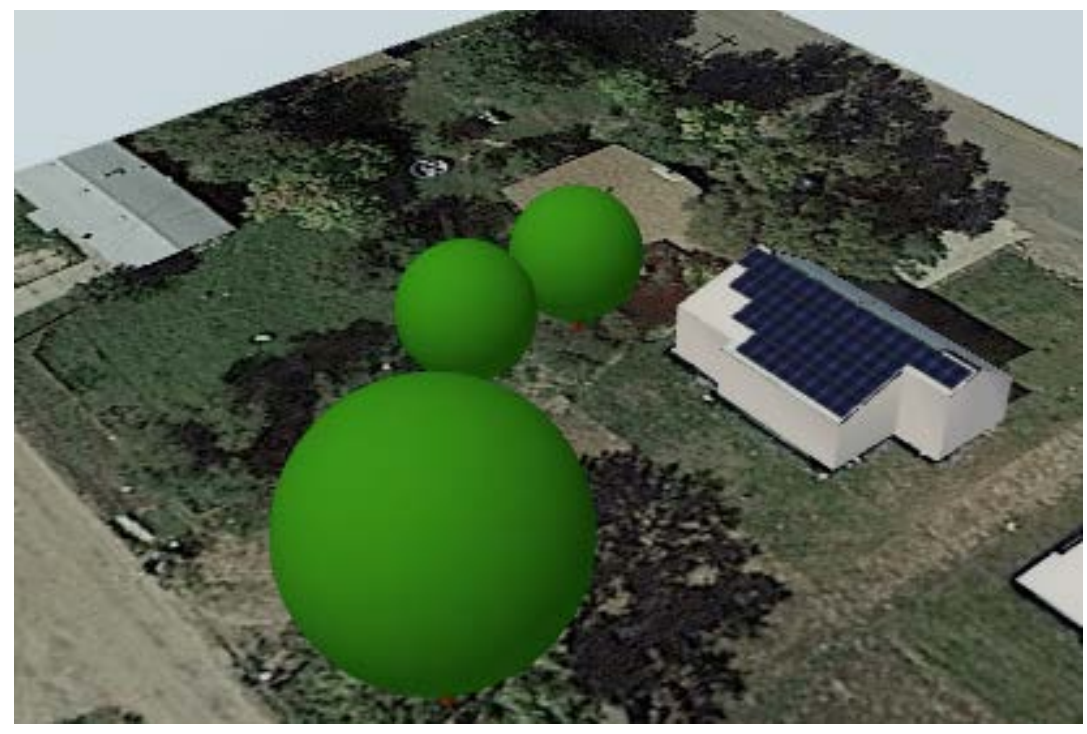

Figure 29. 124 C St East 3D rooftop PV system rendering

There are some trees on the south side of this house; using the Aurora Solar software tool, the annual solar access was estimated as 95\% (Figure 30).
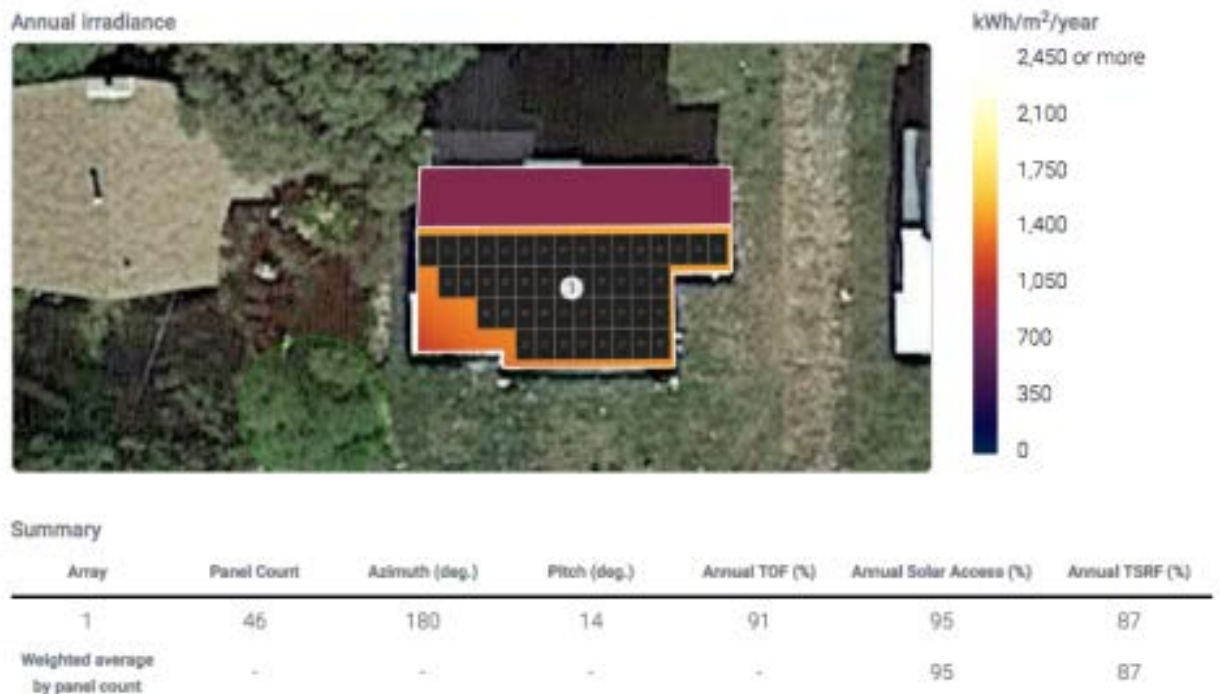

Figure 30. Solar Resource on Roof of Home

The net metering limit for Montana is $50 \mathrm{kw},{ }^{3}$ and the state of Montana has a $\$ 1,000$ rebate for onsite PV systems. ${ }^{4}$ Homeowners are also eligible for a $30 \%$ investment tax credit that offsets $30 \%$ of the upfront cost of a PV system. ${ }^{5}$ The following system characteristics were used to model the technical potential and economics for each house (Table 8).

\footnotetext{
${ }^{3}$ Net Metering Limit, http://programs.dsireusa.org/system/program/detail/37

${ }^{4}$ State Rebate, http://deq.mt.gov/Energy/montanasenergy/taxincentrenew\#nonfossilgeneration

${ }^{5}$ Investment Tax Credit, http://programs.dsireusa.org/system/program/detail/1235
} 
Table 8. PV System Model Input Assumptions

\begin{tabular}{l|l|l|l} 
& Option House & $\begin{array}{l}\mathbf{1 0 0 3} \text { 8th Ave } \\
\text { NE }\end{array}$ & 120 C St East \\
\hline Weather File & $\begin{array}{l}\text { Wolf Point Intl, MT } \\
\text { (TMY3) }\end{array}$ & $\begin{array}{l}\text { Wolf Point Intl, } \\
\text { MT (TMY3) }\end{array}$ & $\begin{array}{l}\text { Wolf Point Intl, } \\
\text { MT (TMY3) }\end{array}$ \\
\hline Solar Panel & $\begin{array}{l}\text { Solar World 290 } \\
\text { Watt }\end{array}$ & $\begin{array}{l}\text { Solar World 290 } \\
\text { Watt }\end{array}$ & $\begin{array}{l}\text { Solar World 290 } \\
\text { Watt }\end{array}$ \\
\hline Orientation & 179.5 & 179.5 & 179.5 \\
\hline Tilt Angle & 10 & 14 & 14 \\
\hline Annual Solar Access & $100 \%$ & $100 \%$ & $95 \%$ \\
\hline System Losses & $11.42 \%$ & $11.42 \%$ & $14.96 \%$ \\
\hline Installed Cost $\$$ /watt) & 3.00 & 3.00 & 3.00 \\
\hline $\begin{array}{l}\text { Installed Cost Bulk Purchase } \\
\text { (\$/watt) }\end{array}$ & 2.00 & 2.00 & 2.00 \\
\hline Electric Rate & 0.08 & 0.08 & 0.08 \\
\hline
\end{tabular}

For each house, the PV systems were sized based on the combined electricity savings for each house and to meet $92 \%$ to $94 \%$ of the remaining electrical load. The economics were analyzed assuming a $\$ 3 /$ watt installed cost and at a lower cost of $\$ 2 /$ watt, assuming Fort Peck was to move forward with a bulk purchase of a PV system for many homes under one purchase. The annual electricity savings, installed costs, and simple payback for each location and each scenario are provided in Table 9.

Table 9. PV System Economic Analysis

\begin{tabular}{|c|c|c|c|c|c|c|}
\hline $\begin{array}{l}\text { Techno-Economic } \\
\text { Category }\end{array}$ & $\begin{array}{c}\text { Option } \\
\text { House } \\
\text { (\$3/Watt) }\end{array}$ & $\begin{array}{l}1003 \text { 8th Ave } \\
\text { NE (\$3/Watt) }\end{array}$ & \begin{tabular}{|l}
120 C Street \\
Poplar MT \\
(\$3/Watt)
\end{tabular} & $\begin{array}{c}\text { Option House } \\
\text { (\$2/Watt) }\end{array}$ & $\begin{array}{l}1003 \text { 8th Ave } \\
\text { NE (\$2/Watt) }\end{array}$ & \begin{tabular}{|l}
120 C Street \\
Poplar MT \\
(\$2/Watt)
\end{tabular} \\
\hline Number of PV Panels & 24 & 41 & 22 & 25 & 41 & 22 \\
\hline System Size & 6.96 & 11.89 & 6.38 & 7.25 & 11.89 & 6.38 \\
\hline Energy Production & 8,363 & 14,744 & 7,592 & 9,049 & 14,744 & 8,130 \\
\hline Installed Cost & $\$ 20,880$ & $\$ 35,670$ & $\$ 19,140$ & $\$ 14,500$ & $\$ 23,780$ & $\$ 12,760$ \\
\hline State Rebate & $\$ 1,000$ & $\$ 1,000$ & $\$ 1,000$ & $\$ 1,000$ & $\$ 1,000$ & $\$ 1,000$ \\
\hline Investment Tax Credit & $\$ 6,264$ & $\$ 10,701$ & $\$ 5,742$ & $\$ 4,350$ & $\$ 7,134$ & $\$ 3,828$ \\
\hline Final Installed Cost & $\$ 13,616$ & $\$ 23,969$ & $\$ 12,398$ & $\$ 9,150$ & $\$ 15,646$ & $\$ 7,932$ \\
\hline Annual Electricity Saving & $\$ 705$ & $\$ 1,241$ & $\$ 641$ & $\$ 762$ & $\$ 1,241$ & $\$ 685$ \\
\hline O\&M Cost & $\$ 70$ & $\$ 119$ & $\$ 64$ & $\$ 73$ & $\$ 119$ & $\$ 64$ \\
\hline Annual Cost Savings & $\$ 635$ & $\$ 1,122$ & $\$ 577$ & $\$ 690$ & $\$ 1,122$ & $\$ 621$ \\
\hline Simple Payback & 21.4 & 21.4 & 21.5 & 13.3 & 13.9 & 12.8 \\
\hline
\end{tabular}

The system size per house ranges from $6.38 \mathrm{~kW}$ to $11.89 \mathrm{~kW}$ to get close to net zero energy electric, and the installed cost per house, including all applicable state and federal rebates, is 
$\$ 12,398$ to $\$ 23,969$ per home. Only a portion of the south-facing roof area available at $120 \mathrm{C}$ Street is needed for a $6.38-\mathrm{kW}$ PV system, and the south-facing roof areas for the other two homes are assumed to be sufficient to house the respective PV systems. (Note these roof images are not available via Google maps and could not be confirmed). The simple payback for the base case is around 21.4 to 21.5 years, and if Fort Peck were to move forward with a bulk purchase of a larger number of systems, the simple payback is estimated to drop to 12.8 to 13.3 years. 


\section{Conclusions and Recommendations}

\subsection{Conclusions}

The homes that were studied as part of this project revealed several interesting insights into the process of implementing high-performance housing in a location where the industry is still being developed.

- The homes in Poplar appear to have been well designed and consider climate-specific design considerations for northeastern Montana.

- The largest issues that were identified with the MIRF homes was related to the site work that was done to put the homes on the foundation, insulate the crawlspaces, and make the final connections with the utilities.

- The Taxed II Credit homes are well designed, and with slight modifications to the design and construction, could be very energy efficient.

- All occupant comfort and energy use issues that were identified during the site visits can be remedied through retrofit measures that are relatively inexpensive.

- Energy-efficiency opportunities were found that can be implemented in each of the homes. These retrofits are generally inexpensive and have a quick return on investment.

- The designs of the homes can be improved to save energy, and the incremental cost of the improvements is generally low.

- Renewable energy systems are economically feasible in this area, but the payback is on the high side of what would likely be acceptable to homeowners. If the price of solar comes down to $\$ 2 /$ watt installed, the systems will achieve a simple payback of 13 years, which is likely a return on investment that is attractive to homeowners.

- If the homes are made sufficiently tight to be high performance, ERVs will be necessary to maintain acceptable indoor air quality. The Taxed II Credit homes are already equipped with ERVs, and they seem to function well.

- As PV prices continue to decline, start implementing projects as they become cost effective.

\subsection{Recommendations}

- All housing in the Fort Peck community should have a blower door test prior to final acceptance. Air infiltration has a substantial impact on both energy use and occupant comfort in this climate, and even small air gaps have the potential to negatively impact and/or damage homes.

- Tribal staff should inspect all workmanship prior to final acceptance, paying particular attention to furnace venting, insulation application, water/sewer lines, and life safety equipment.

- Energy management systems should be implemented. There are large opportunities to save energy through smart thermostats and plug load control. These systems should be designed with either limited occupant interaction (such as a self-programming 
thermostat), or occupant training programs as part of the implementation. Currently, the thermostats are complicated, and few of them were being used to their full potential.

- The opportunities for energy savings are large in existing homes. There are energy efficiency grants available through the Office of Indian Energy that could be used to set up a team of people to implement energy-efficiency projects on the homes. Homes should have an energy audit with blower door test every 3 to 4 years, or whenever occupants turn over.

- With any vented crawlspace, extra care needs to be given to insulating plumbing and DHW lines. This will help to avoid operational problems in the future.

- When designing high-efficiency housing in rural communities such as Poplar, consideration should be given to the availability of technicians to service the mechanical systems that are selected in the design. The combination boiler/DHW units may present a maintenance challenge when it comes time to service the units. A more traditional forced air or hydronic system may be a better option for this location.

- Given the tremendous positive impact that energy efficiency can have on residents of the community, it is recommended that the housing authority support a team of people to make the rounds and implement energy-efficiency measures. The efficiency team could be funded by a weatherization program or potentially as a paid service. This would reduce the amount of money spent on energy (which leaves the community), improve the comfort of the homes, and employ members of the community. 


\section{Appendix A: Metered Data}

Over a period from March to August, metering equipment was installed on several housing units in Poplar, Montana. The meters measured electrical consumption and space temperature. The results of the metering are shown below. From the data, conclusions can be drawn around occupant comfort and operation of the home systems.

\section{Temperature Data}

\section{MIRF Homes}
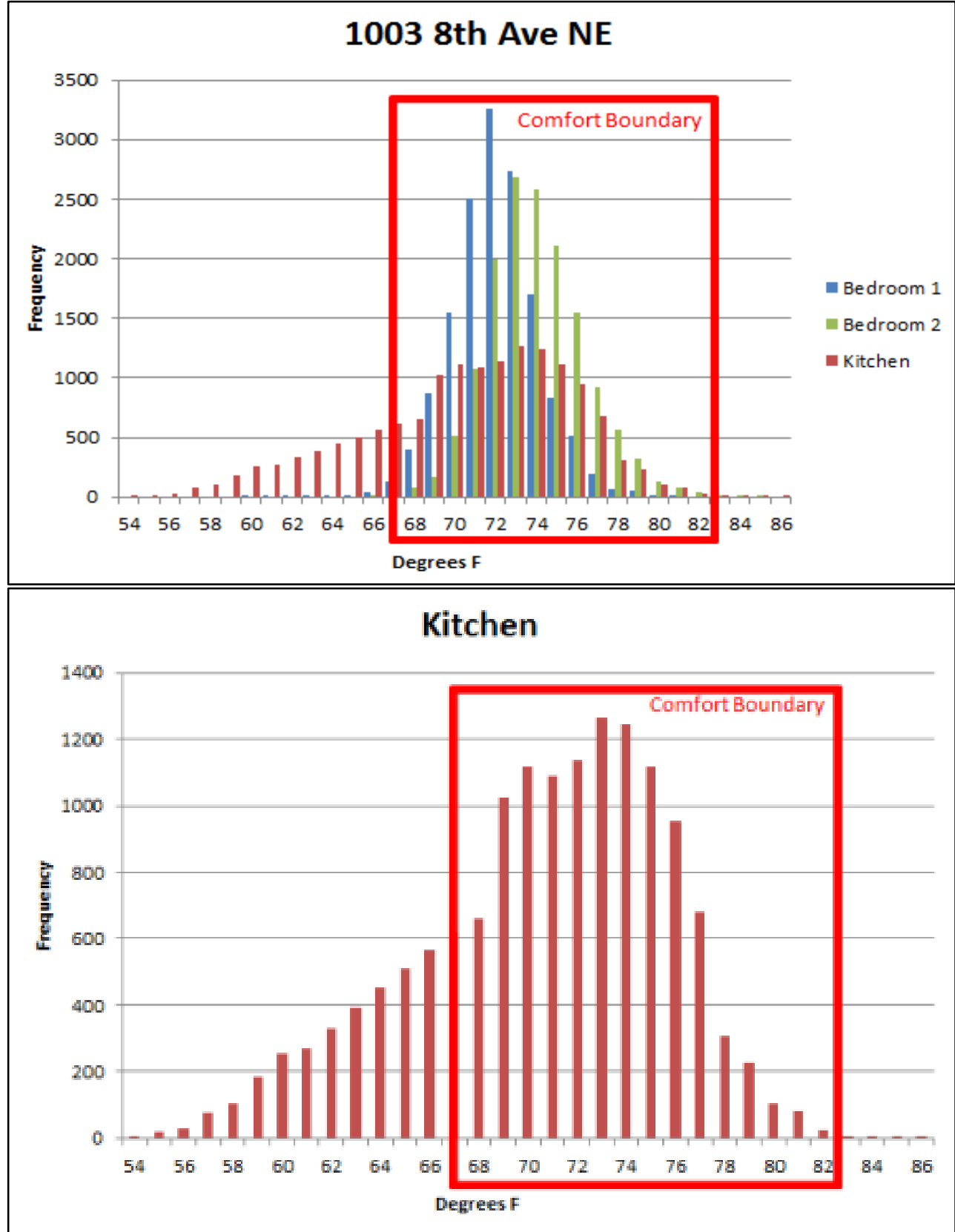

- Below comfort boundary - 799 hours

- Above comfort boundary -4.5 hours 


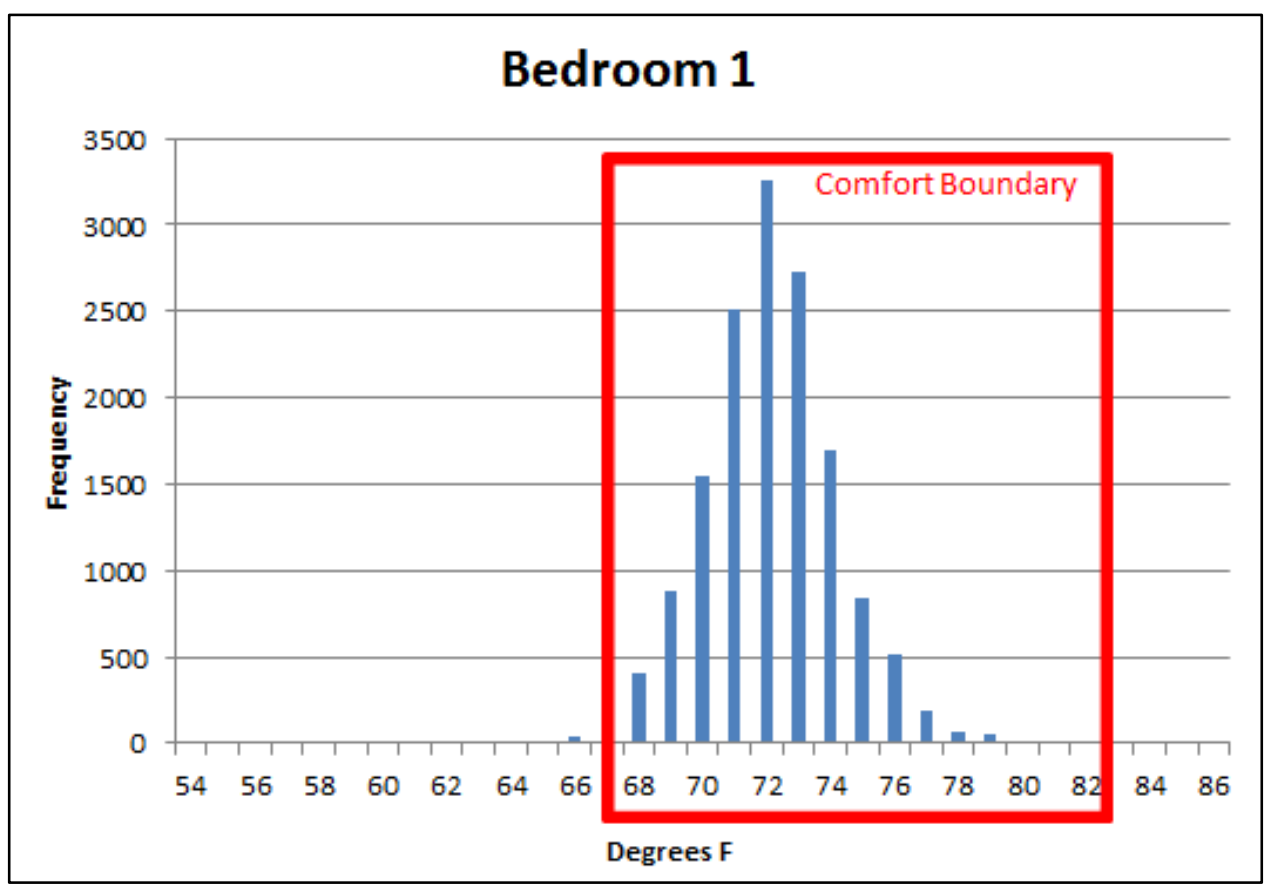

- Below comfort boundary - 13 hours

- Above comfort boundary - 0 hours

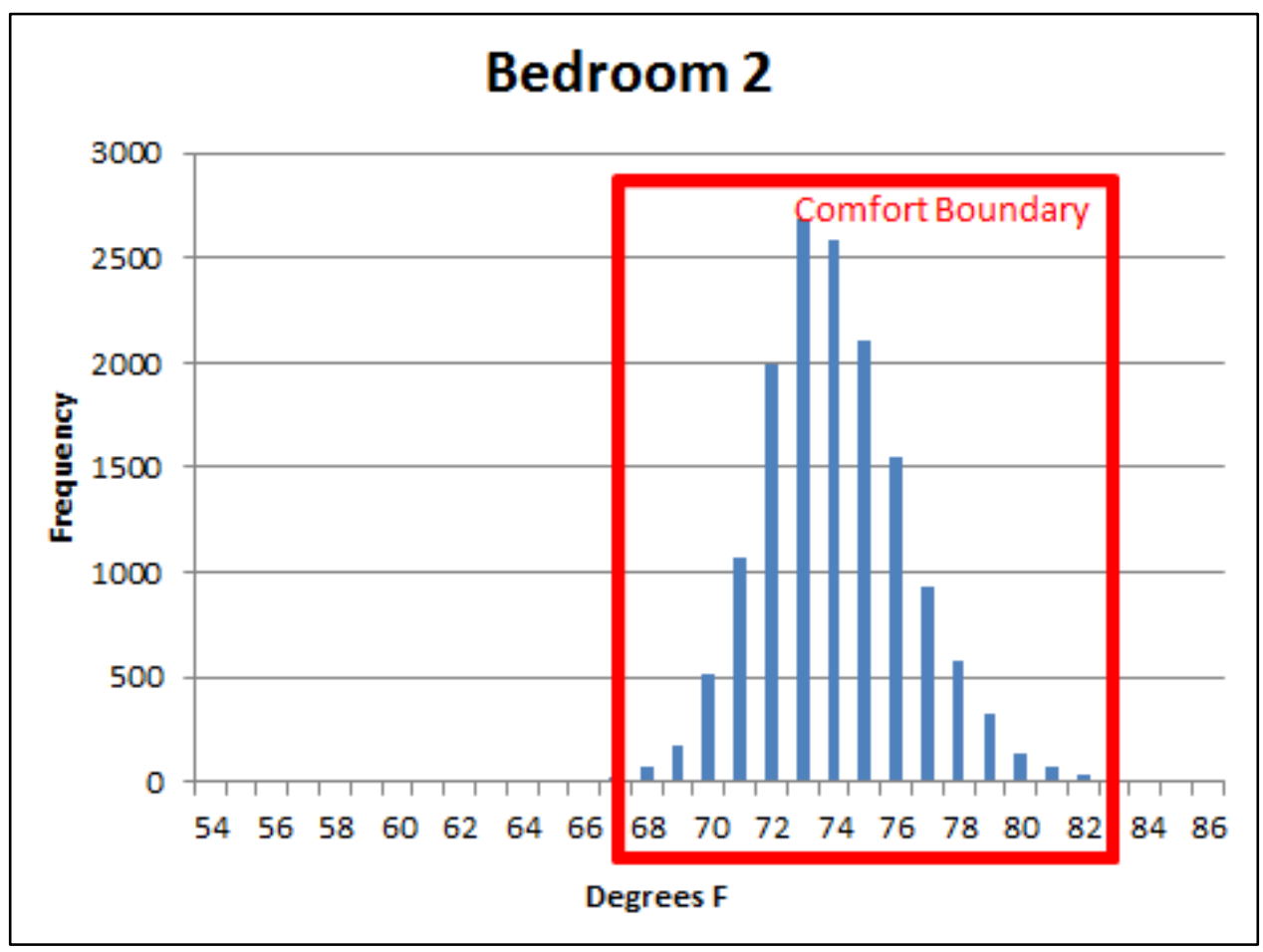

- Below comfort boundary - 1 hour

- Above comfort boundary - 7 hours 


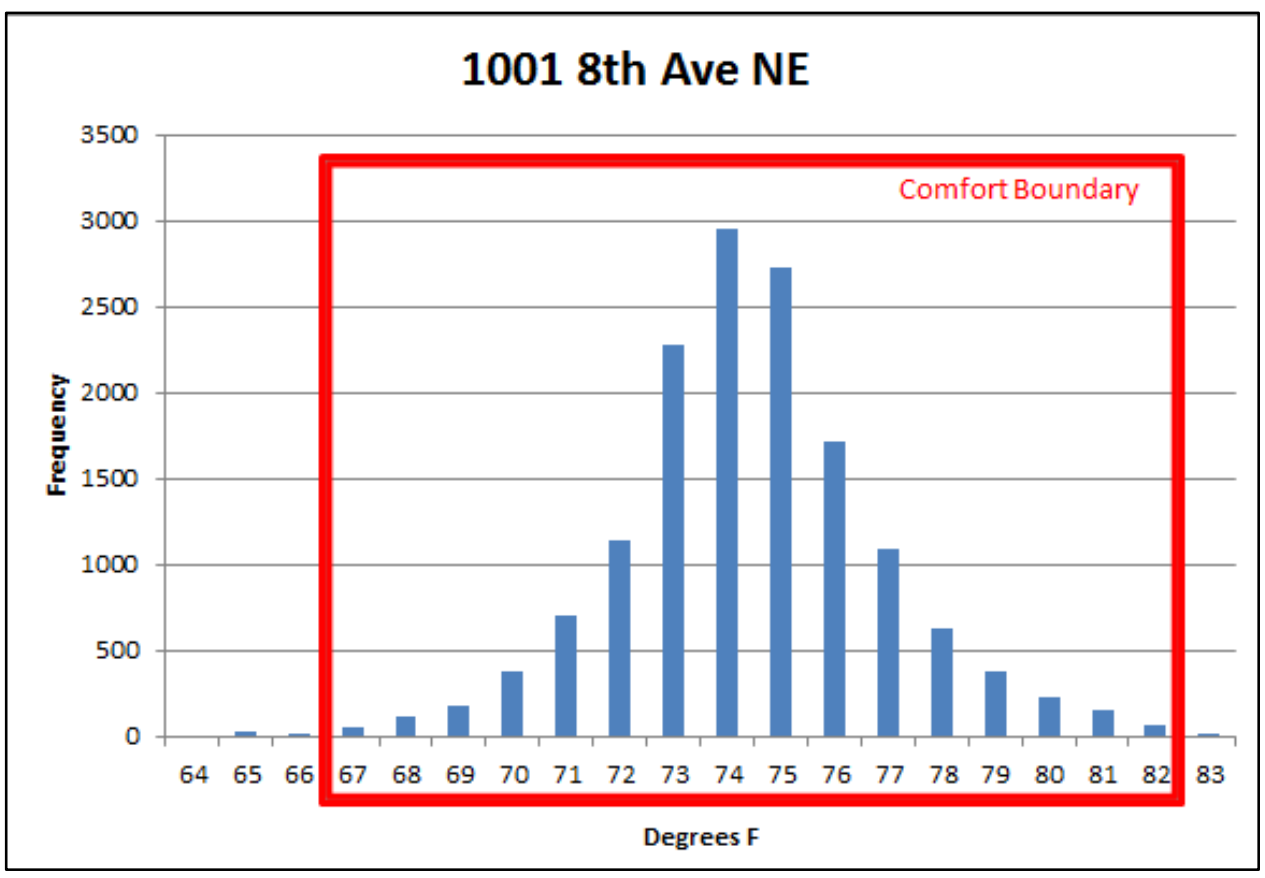

- Below comfort boundary - 10 hours

- Above comfort boundary - 3.5 hours

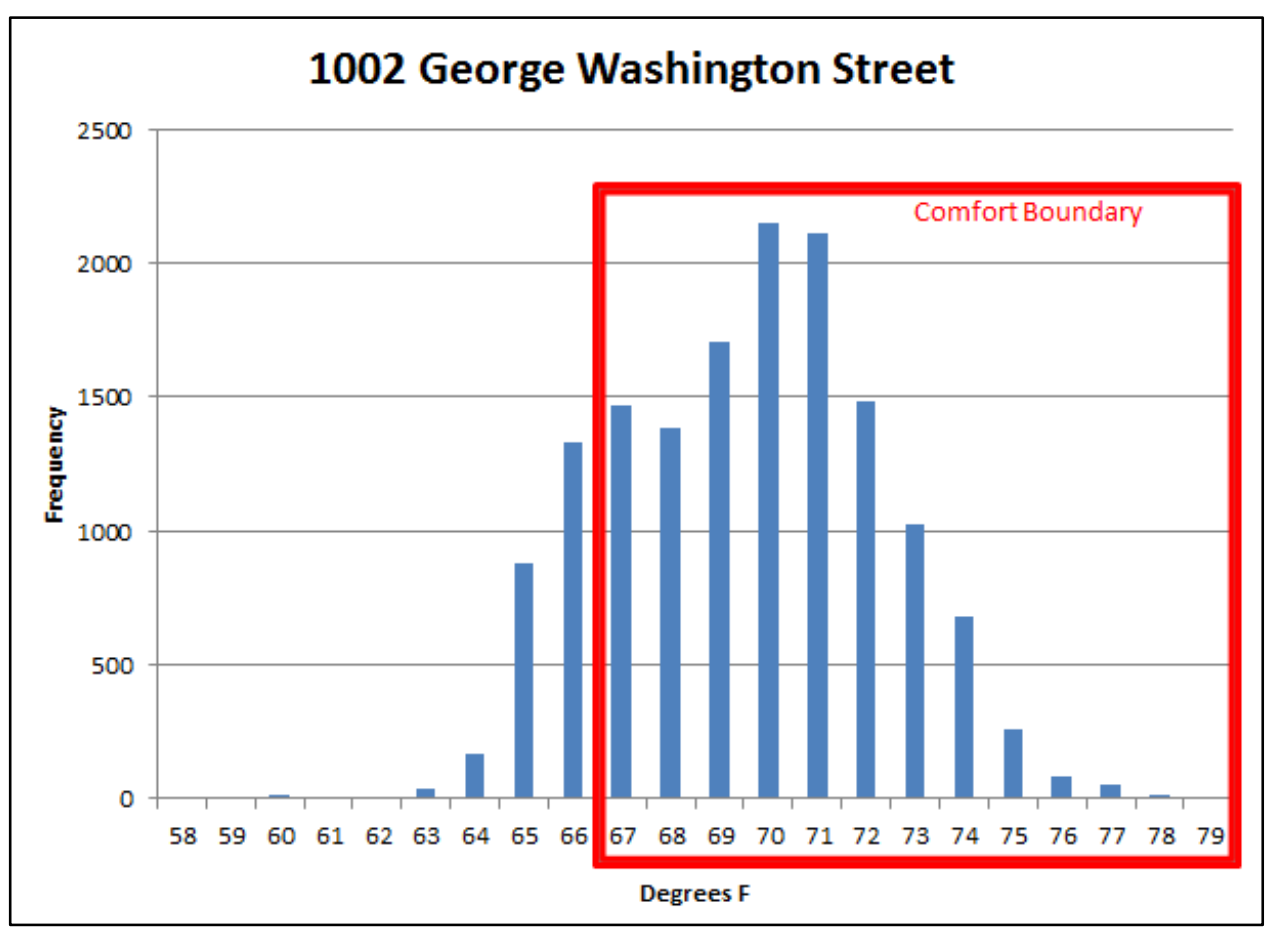

- Below comfort boundary - 612 hours

- Above comfort boundary - 0 hours 


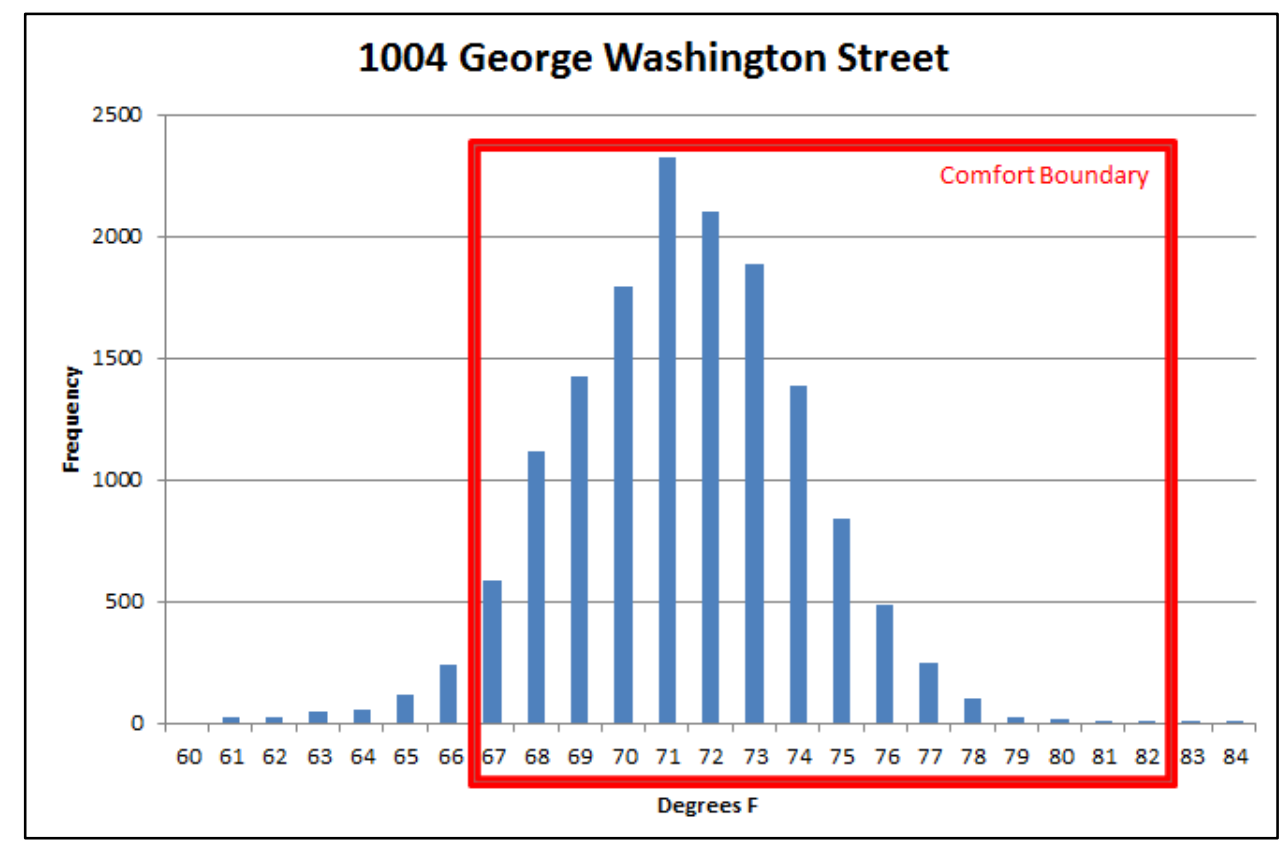

- Below comfort boundary - 128 hours

- Above comfort boundary -2 hours

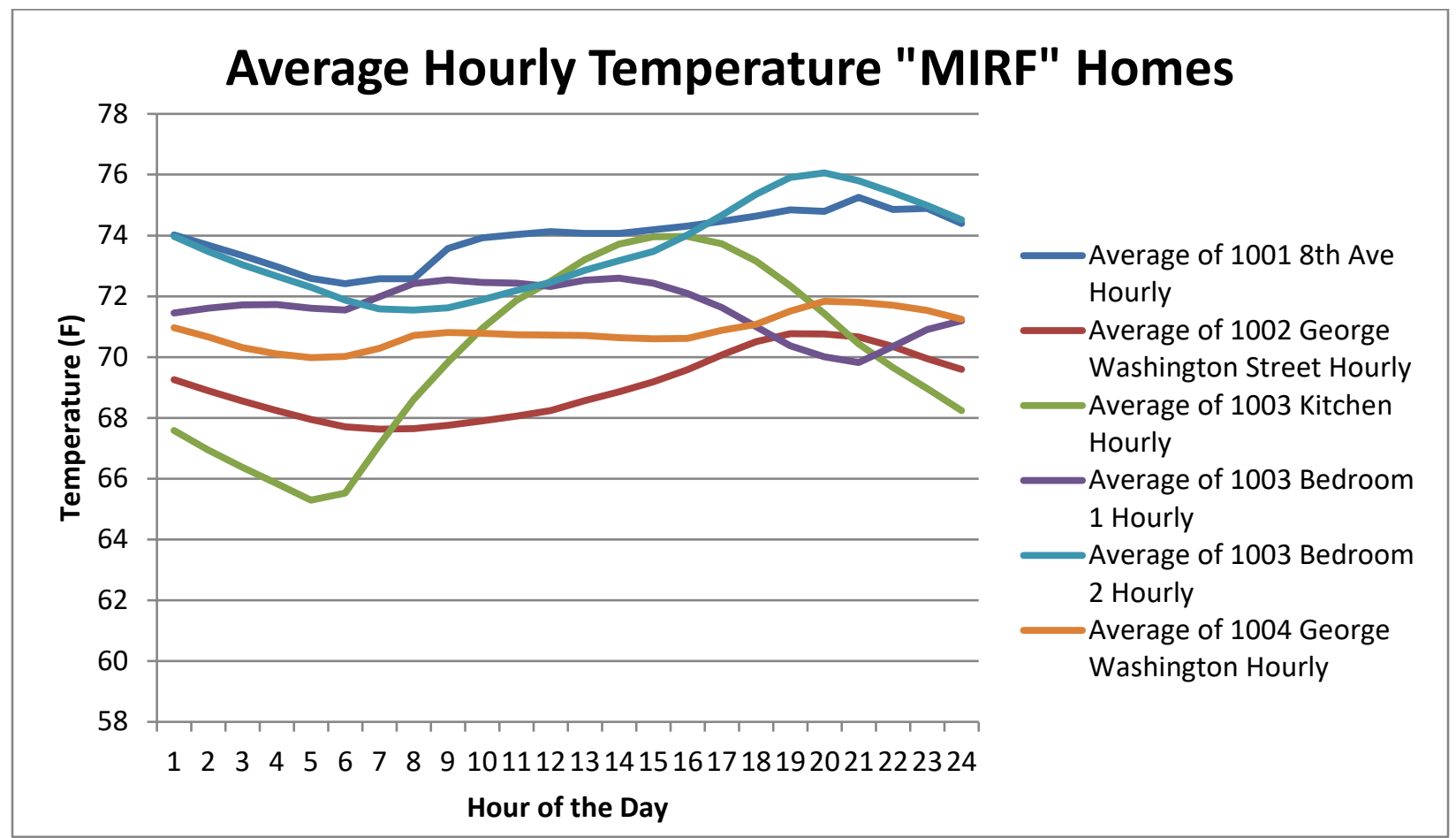

Averaging the temperature metered data across all the homes and spaces, the following is a summary of the hours that the homes are outside of the comfortable range:

- Below: 261 hours/home

- Above: 3 hours/home 


\section{Taxed II Credit Homes}

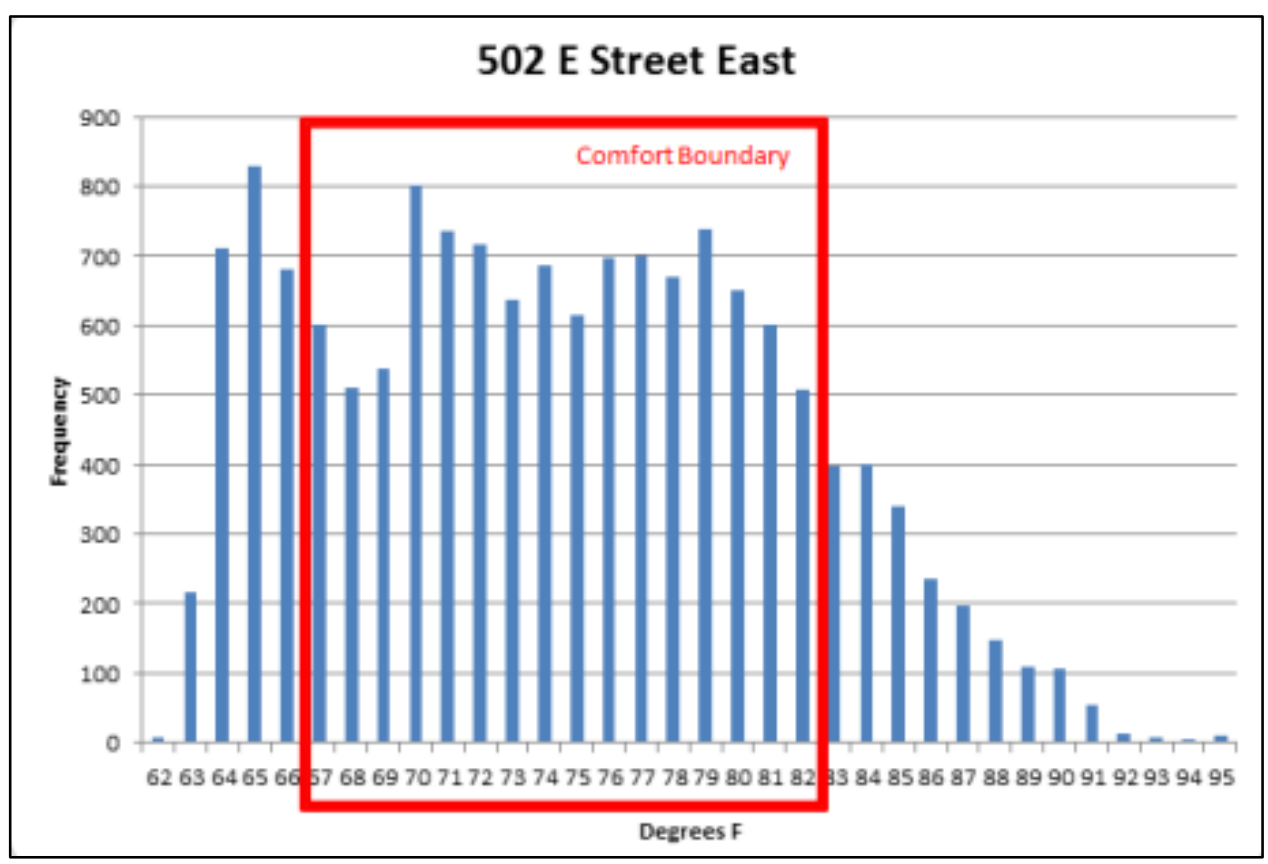

- Below comfort boundary - 611 hours

- Above comfort boundary -507 hours

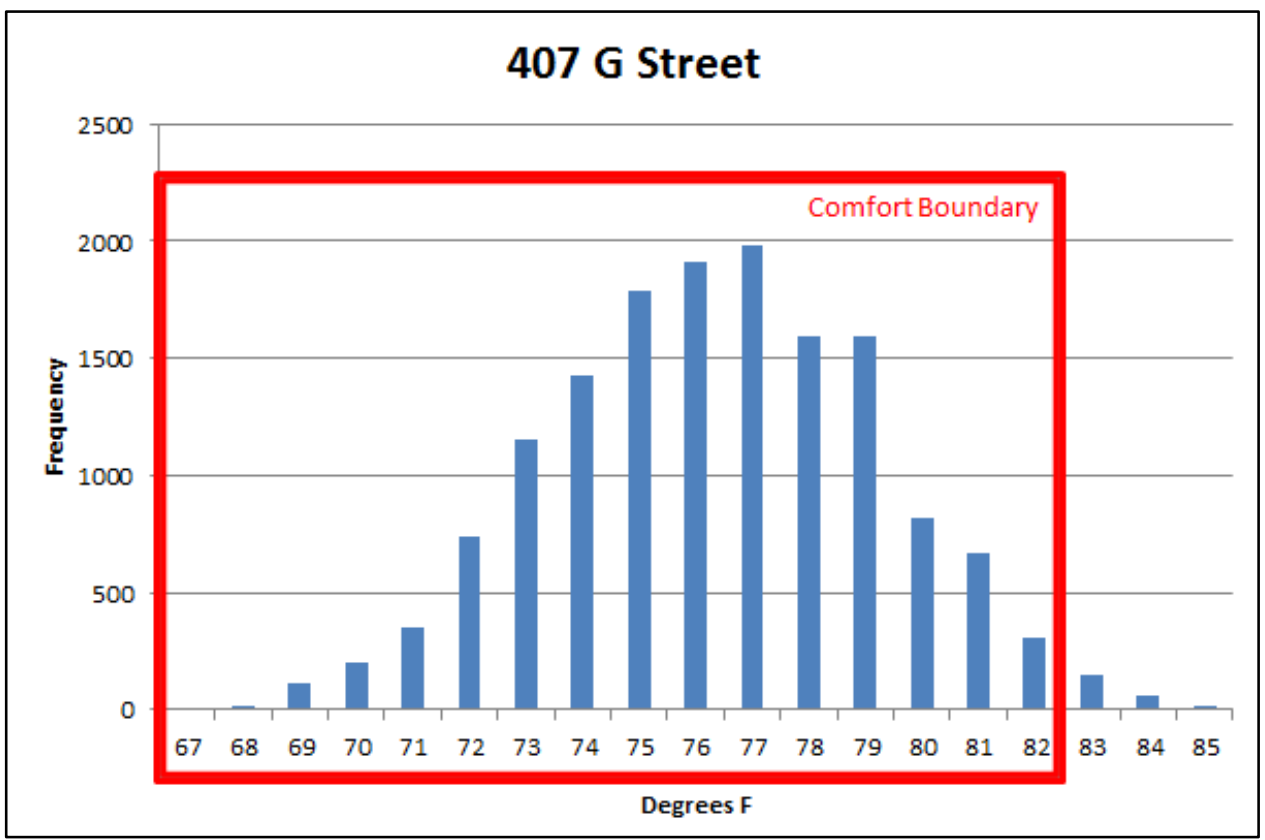

- Below comfort boundary -0 hours

- Above comfort boundary -56 hours 


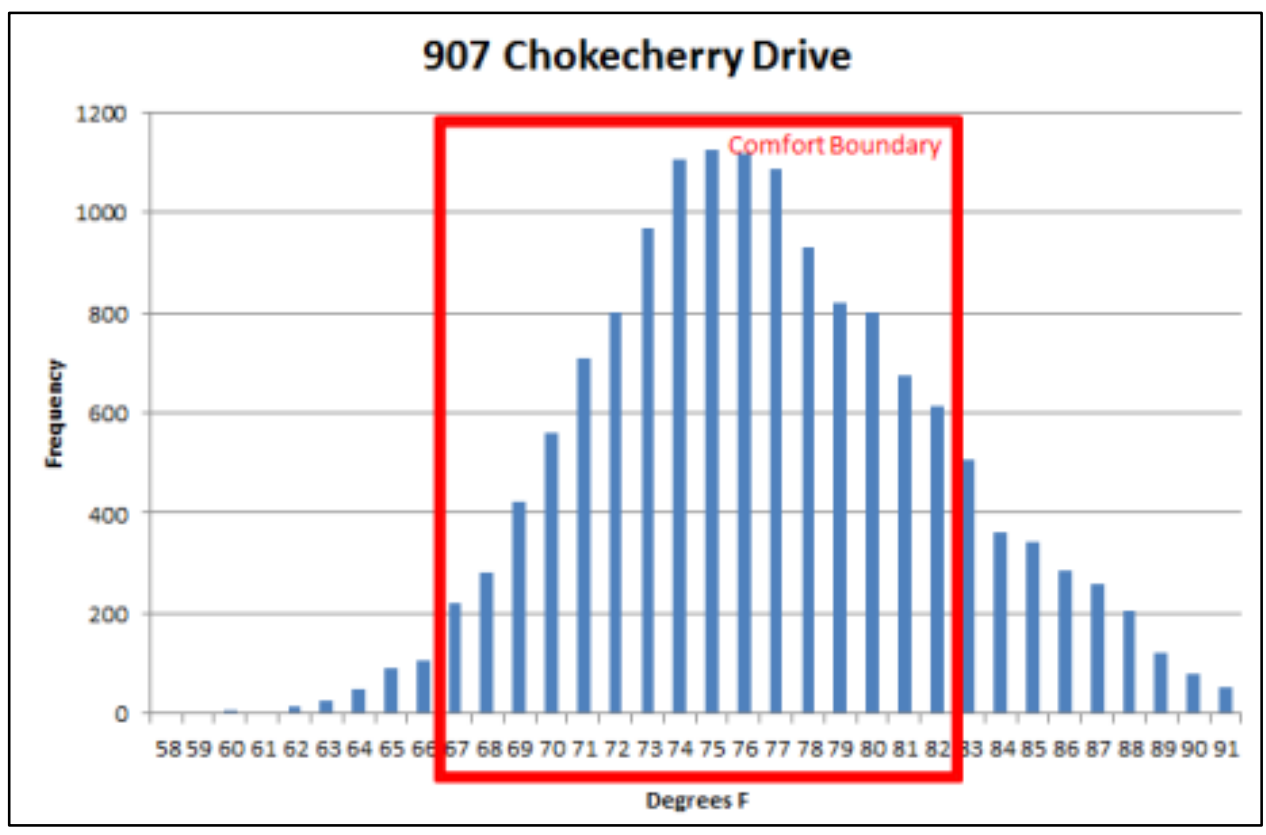

- Below comfort boundary - 75 hours

- Above comfort boundary - 553 hours

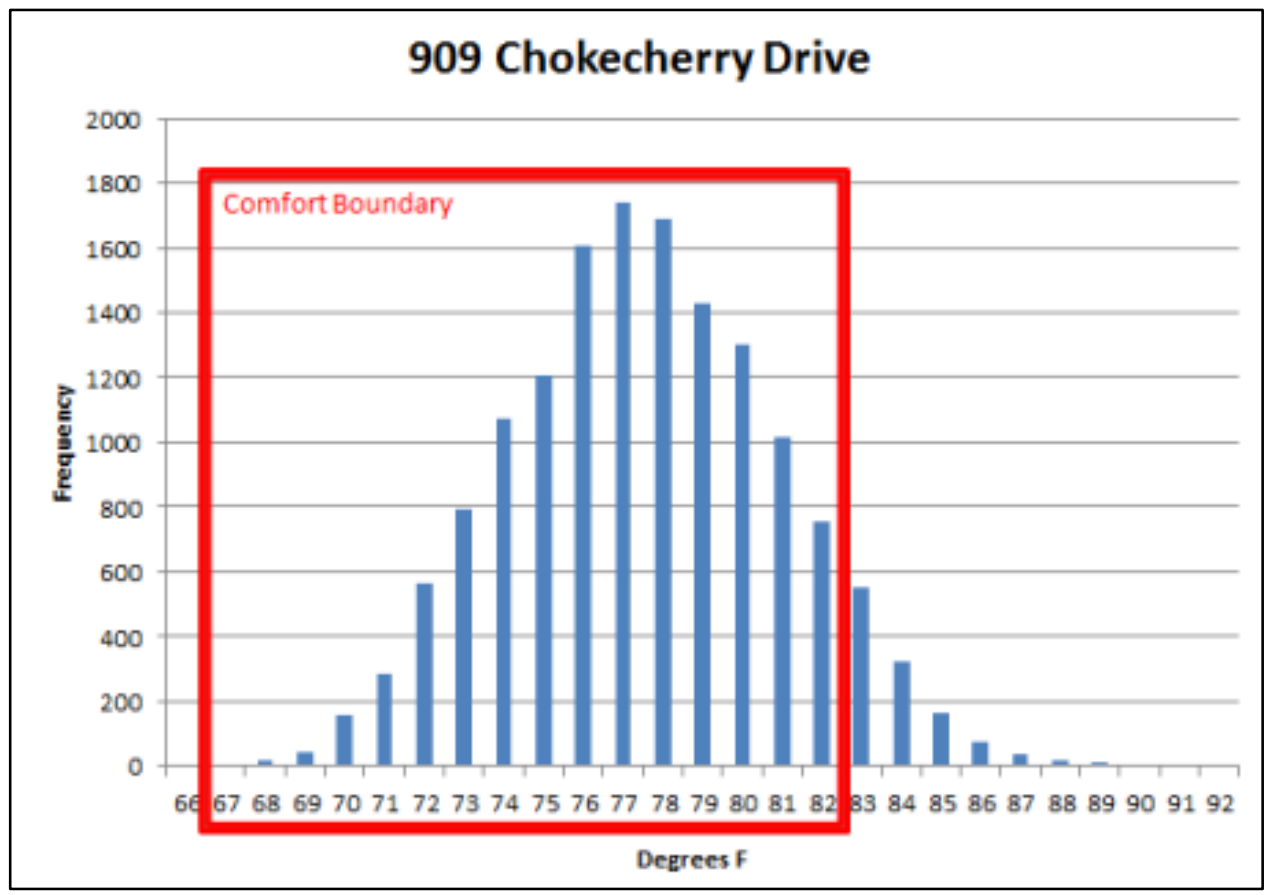

- Below comfort boundary - 0 hours

- Above comfort boundary - 299 hours 


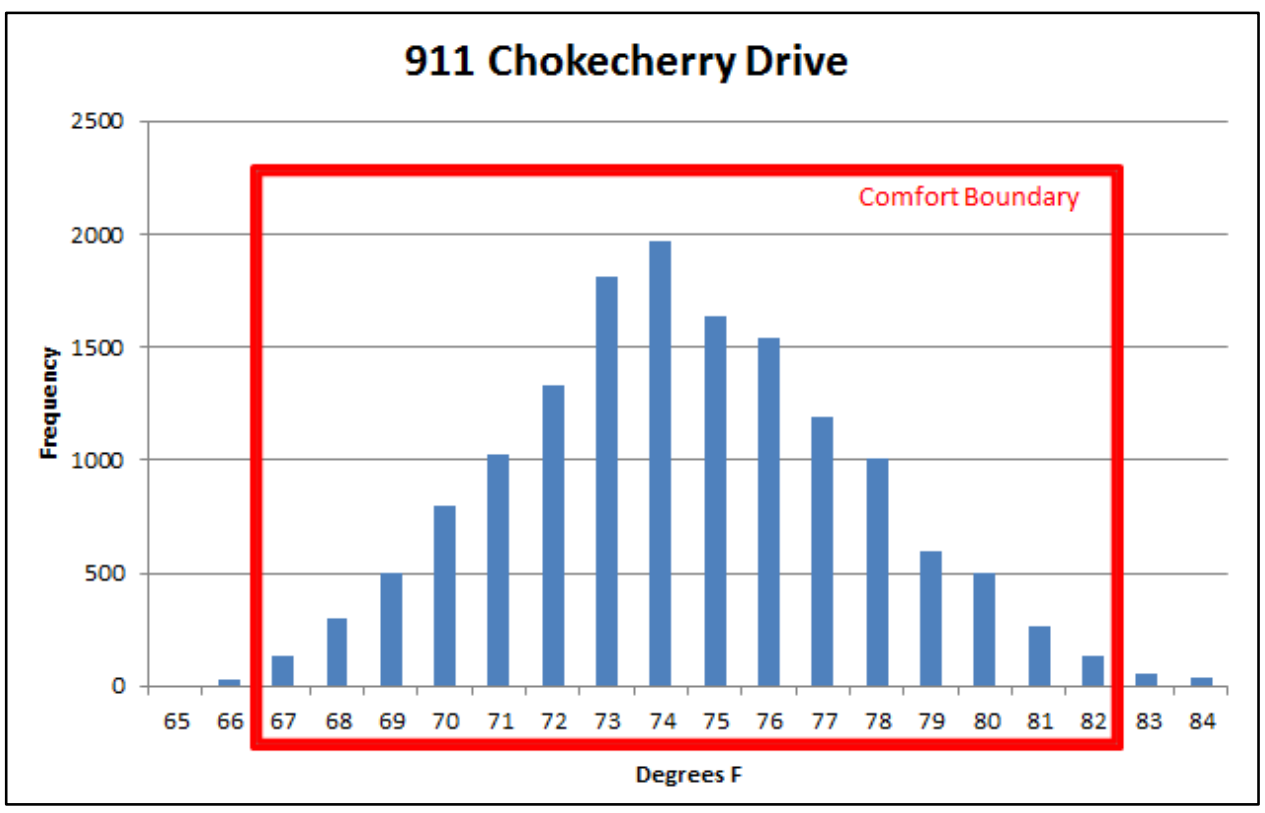

- Below comfort boundary -7 hours

- Above comfort boundary -23 hours

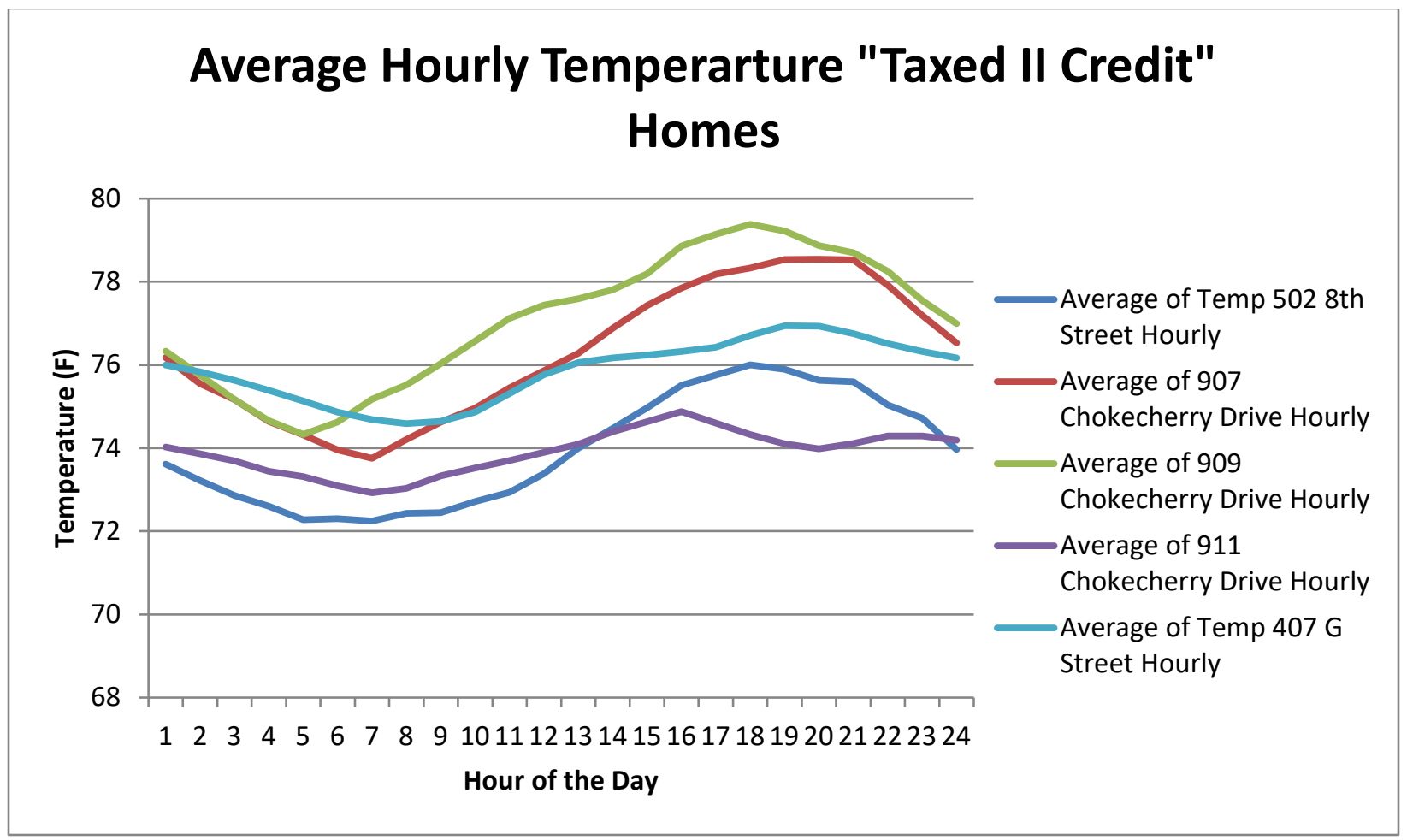

Averaging the temperature metered data across all the homes and spaces, the following is a summary of the hours that the homes are outside of the comfortable range:

- Below: 139 hours/home

- Above: 293 hours/home 


\section{Electrical Consumption Data}

\section{MIRF Homes}
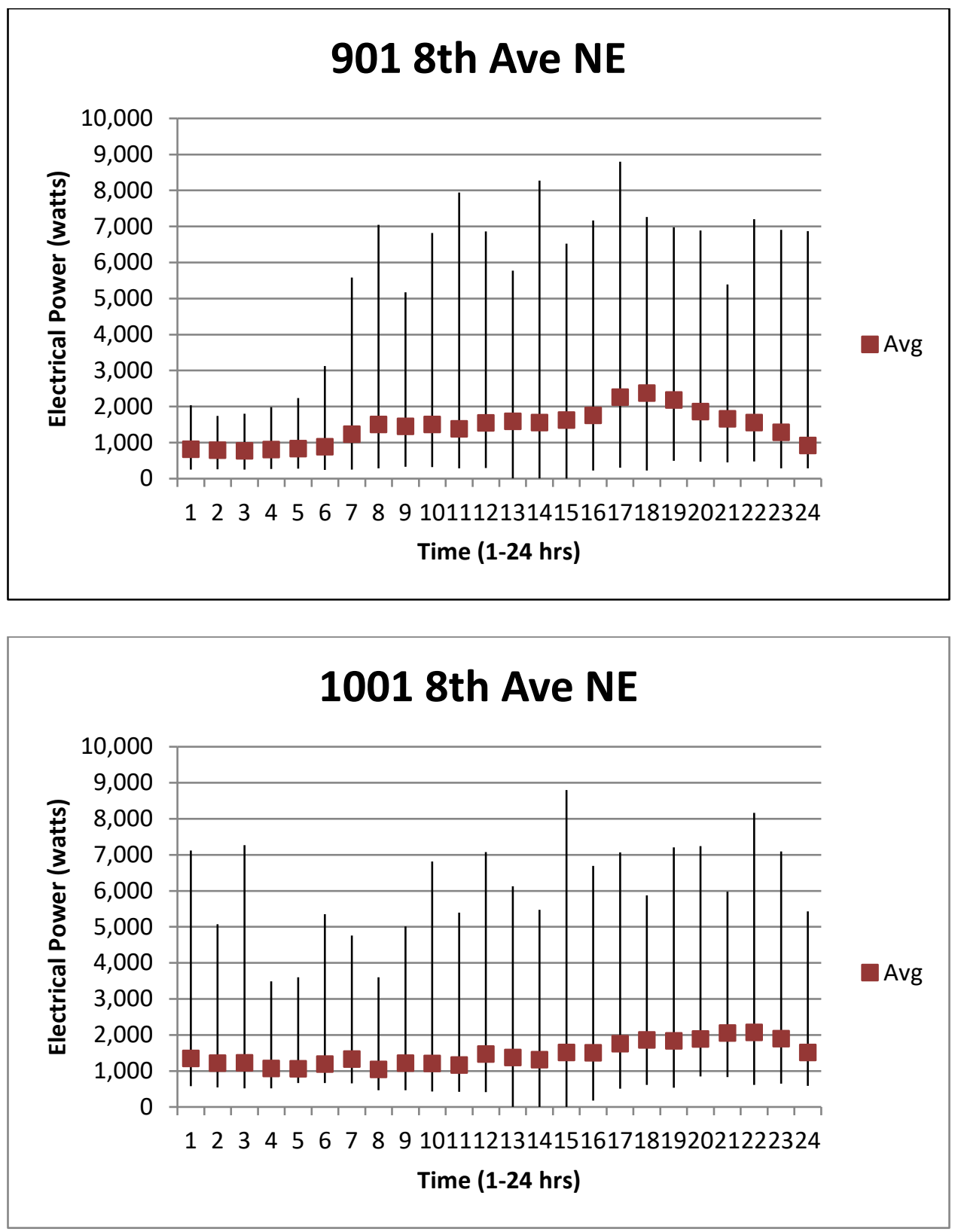


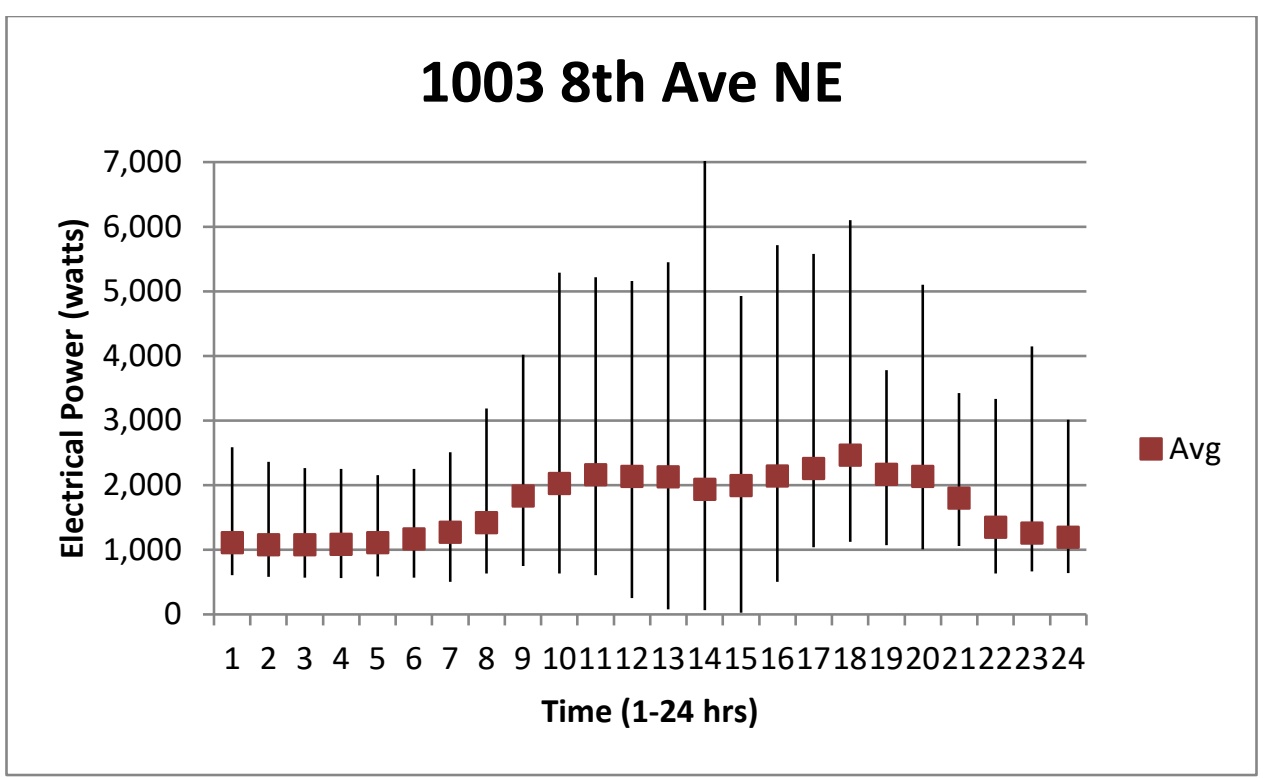




\section{$\underline{\text { Taxed II Credit Homes }}$}
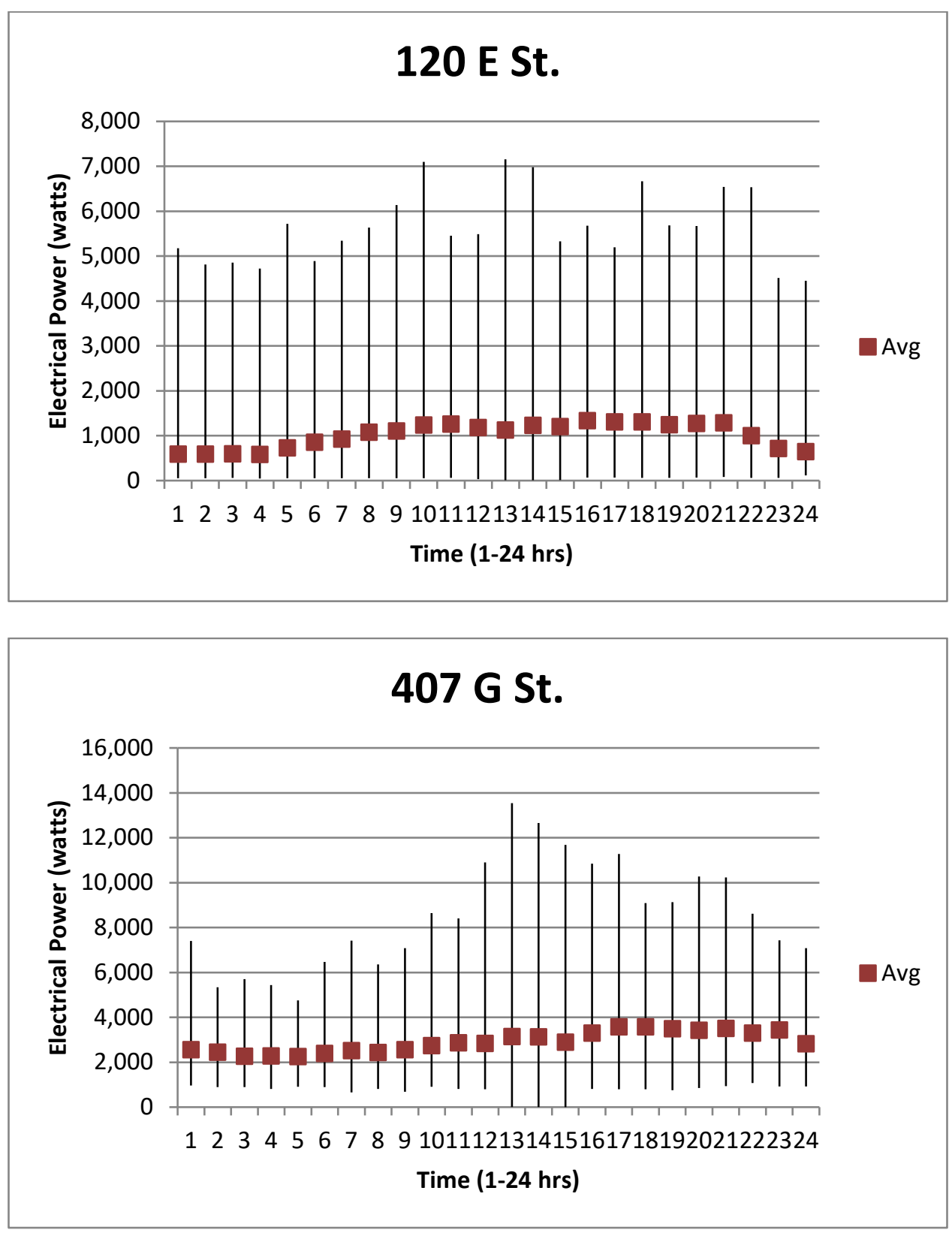

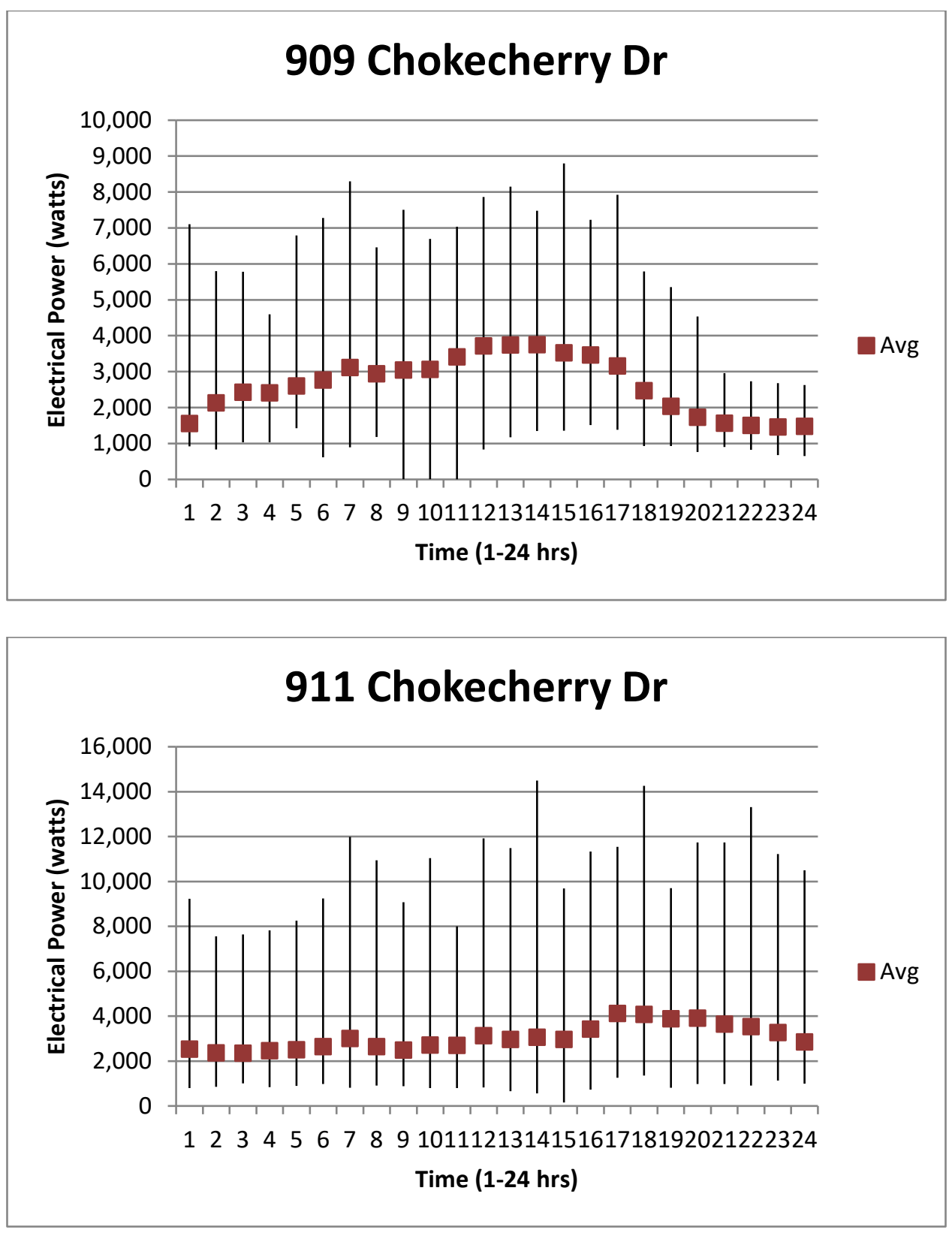


\section{Appendix B: Energy Audit Data}

\section{Energy Audit Report}

$10038^{\text {th }}$ Avenue NE

Living Model

Poplar MT

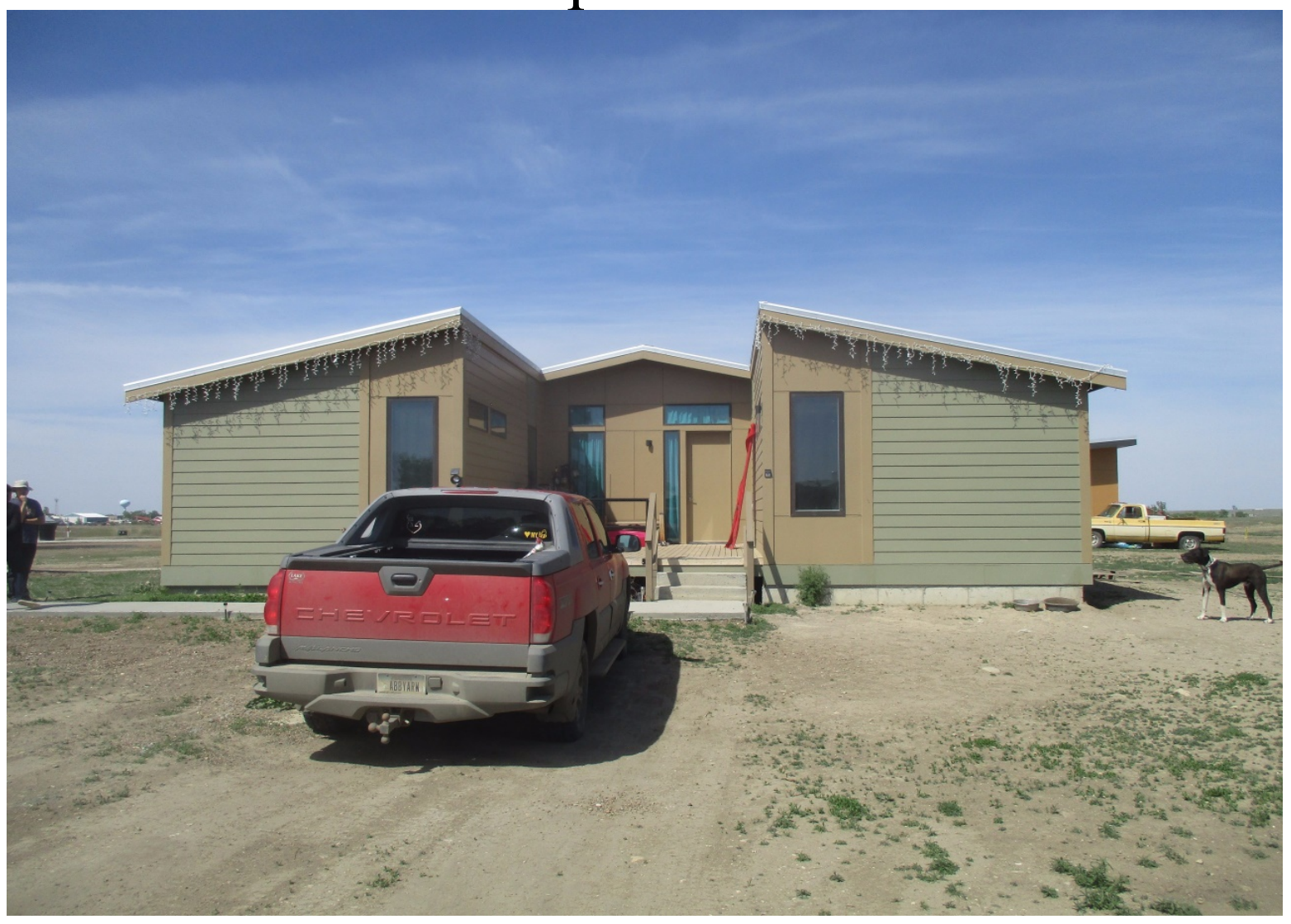

\section{Home Data}




\begin{tabular}{|c|c|}
\hline Address & $10038^{\text {th }}$ Ave NE \\
\hline Year Built & 2016 \\
\hline Size & 1517 \\
\hline Direction & East \\
\hline Average Ceiling Height ( $\mathrm{ft}$ ) & 10 \\
\hline Blower Door & $1218 \mathrm{CFM}$ ACH $=4.81$ \\
\hline Natural Air Changes & $\mathrm{NACH}=0.28$ \\
\hline Foundation & Vented Crawl R-38 at Floor \\
\hline Vapor Barrier & Poor - Standing water \\
\hline Attic & Vented attic SIP R-45 \\
\hline Walls & R-21 + R-4 Exterior \\
\hline Windows & Fiberglass $U=0.3415 \%$ of wall area \\
\hline Doors & Steel insulated (1) \\
\hline Lighting & 25 CFLs or LEDs with 4 exterior halogen \\
\hline Thermostat & $68-70$ degrees \\
\hline Duct Work & High velocity well sealed \\
\hline Heating & Water to air heat exchanger \\
\hline & American Standard 4A7A024 2 ton SEER $=14-$ \\
\hline Cooling & 16 \\
\hline Ventilation & Exhaust Only \\
\hline Water Heater & Rinnai RUC 98 \\
\hline Water Heater Efficiency & $92 \%$ \\
\hline DHW Temperature & $140 \mathrm{~F}$ \\
\hline Ambient CO Level & 0-1 ppm (PASS) \\
\hline Combustion Air & Sealed Combustion units \\
\hline & $\begin{array}{l}\text { It was not possible to test the CO level in the } \\
\text { flue because the termination point is on the }\end{array}$ \\
\hline DHW CO (air free) ppm & roof \\
\hline Safety Testing & Yes \\
\hline Appliances Energy Star & Yes \\
\hline
\end{tabular}




\section{General Housing Description:}

This home is a single story single family home, which is located in the sustainable village in Poplar, MT. The home was manufactured off site, hauled to the site in three pieces and assembled on a permanent foundation. Although most of the construction was done off site, some insulation and air sealing was done on location. Generally, this site work was poor quality and needs to be repaired. The recommended measures are outlined below in the recommendations section. The homes utilize a combi unit water heater that provides hot water for DHW and for space heating. The hot water is piped from the water heater to a water to air heat exchanger for space heating. The homes are cooled by a DX central cooling unit. The homes were designed with a vented, unconditioned crawl space and a vapor barrier.

\section{Housing Inspection Notes:}

1. Crawl space ceiling (main level floor) is poorly insulated. The existing R-38 batts are substantially degraded because they are misaligned and falling down in places. This results in cold floors and occupant discomfort.

2. The vapor barrier is poorly installed and there is standing water in parts of the crawl space.

3. The radon fan is not glued at the seams, and does not appear to be providing enough negative pressure to properly evacuate the crawl space.

4. The Rinnai water heater is not properly installed. The direct supply combustion air is not attached. The unit receives its combustion air from the house and closet. The home has substantial air leakage and the heater is currently operating safely.

5. There are numerous air leaks throughout the home include a leak by the pocket door. There is a crack in the drywall at approximately the same location, which is nearby the area where the modular sections are connected. It is likely that the attachment of the module units was not properly done and resulted in air leaks.

6. The roof attic seems to be vented. There are round ventilation holes at the soffit areas. The team identified several areas where air leaks allow this unconditioned air into the home, including air leaks at the pocket door, HVAC closet and other areas in the home.

7. Water lines were not properly secured to the ceiling of crawl space. The water lines should be relocated to the upper side of the insulation so that they are against the floor instead of exposed to the unconditioned crawl space.

8. There are high solar radiant gains on south and west windows, causing those parts of the home to heat up.

9. It may be beneficial to seal the soffit vents of the home. It should be discussed with the architect prior to implementation.

10. The rim joist should be sealed, this could be accomplished by using two part spray foam on the perimeter of the foundation in the crawl space. Alternatively the existing batt insulation could be removed and the entire ceiling of the crawl space could be spray foamed, but this would be substantially more costly. 


\section{Recommendations:}

\begin{tabular}{|c|c|}
\hline Recommendations: & Cost \\
\hline 1. Relocate water lines to upper side of insulation & $\$ 1,000-\$ 1,500$ \\
\hline $\begin{array}{l}\text { 2. Seal rim joist where it connects to the home with } \\
\text { two part spray foam }\end{array}$ & $\$ 600$ \\
\hline $\begin{array}{l}\text { 3. Alternative: spray foam the entire ceiling of the } \\
\text { crawl space }\end{array}$ & $\$ 4,000$ \\
\hline $\begin{array}{l}\text { 4. Remove and install correct insulation in crawl } \\
\text { space }\end{array}$ & $\$ 2,000-\$ 3,000$ \\
\hline 5. Repair radon fan & $\$ 100$ \\
\hline 6. Add combustion air to the Rinnai water heater & $\$ 400$ \\
\hline $\begin{array}{l}\text { 7. Air seal all sources of leakage with the crawl space } \\
\text { and attic }\end{array}$ & $\$ 700-\$ 1,500$ \\
\hline 8. Repair vapor barrier & $\$ 150$ \\
\hline 9. Air Seal HVAC closet & $\$ 200$ \\
\hline 10. Install reflected shades to reduce solar gain & $\$ 3,000$ \\
\hline
\end{tabular}

\section{Safety:}

1. There is currently no combustion air for the water heater, this can lead to unsafe indoor air quality.

2. There is standing water in the crawl space. If not properly addressed, this can lead to mold issues and damage to the home.

\section{Conclusion:}

This style of home in the sustainable village performed the poorest of the three models tested. The reasons are part design and part occupant behavior.

Design : The combination of a vented crawl and vented attic are combining to make the home much less air tight than the other two models. Both the attic and the crawl space are connected to the home through air leaks and gaps in insulation. In the winter time, the warm air of the home moves toward both the attic and the crawl space. This affects the comfort of the occupants and increases the operating cost of the water heater.

Occupant behavior: The homeowner was concerned about home safety and the outdoor lights were left on 24 hours a day. The light switch was taped in the "on position". The outdoor LED lamps were replaced with the incandescent variety. A better solution would be to change the lamps back to LED and install motion sensors on each of the lamps. It was estimated that the outdoor lighting use accounted for 30-40\% of the monthly electrical usage. 


\section{Site Visit Pictures}

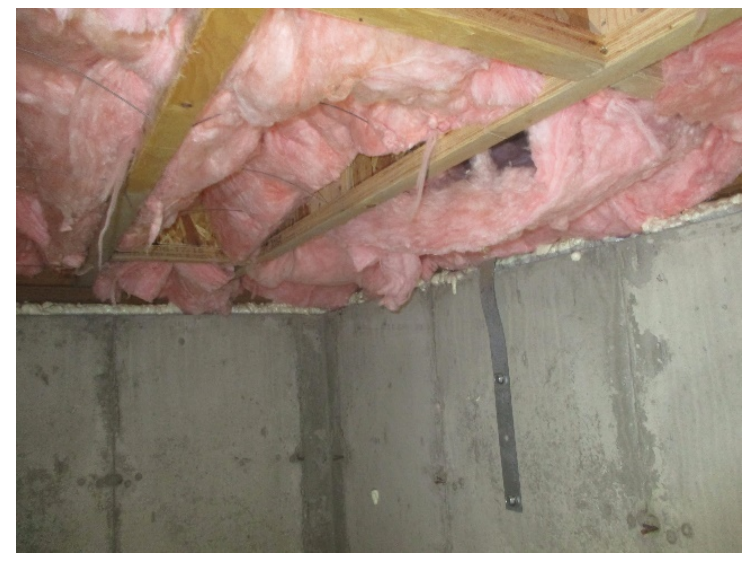

Poorly done insulation in the crawl space ceiling

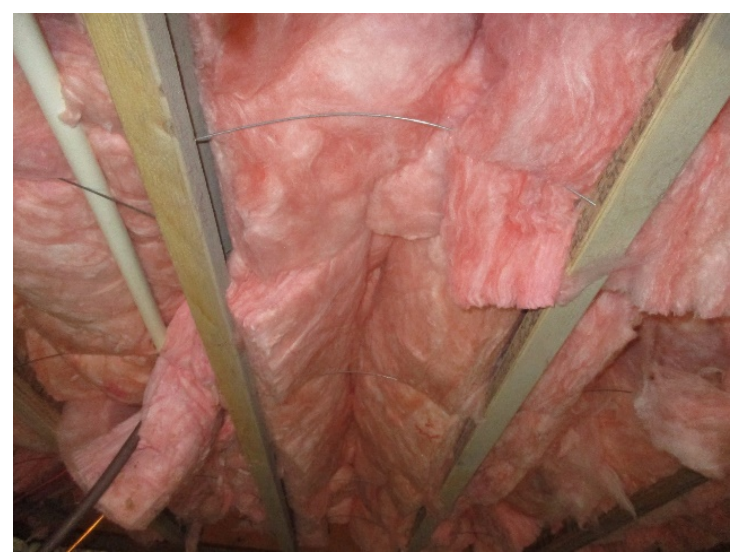

Crawl space insulation

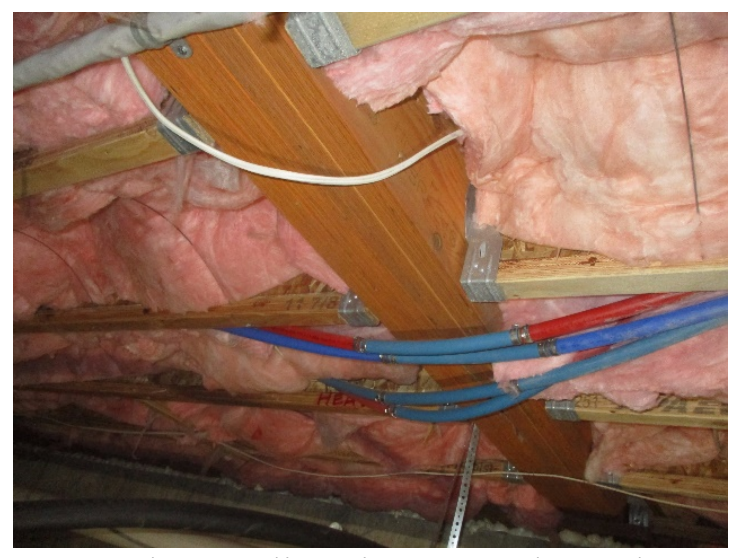

Exposed water lines in a vented crawl space

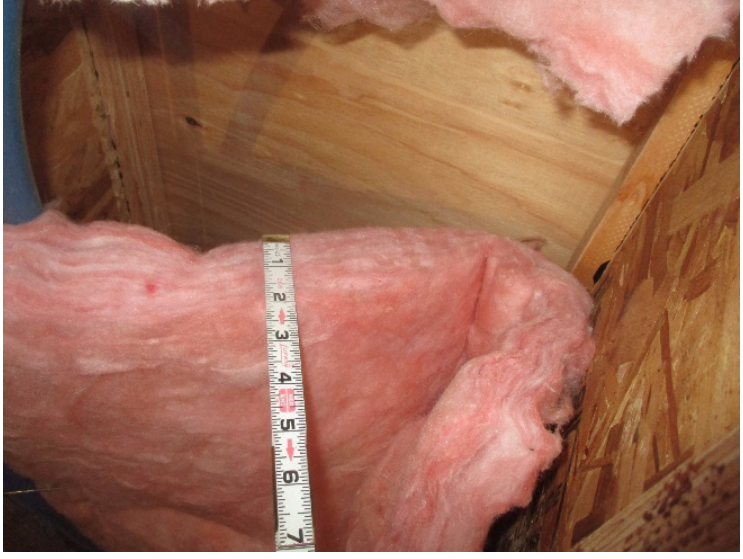

A 3" R-13 batt installed instead of an R-38 batt

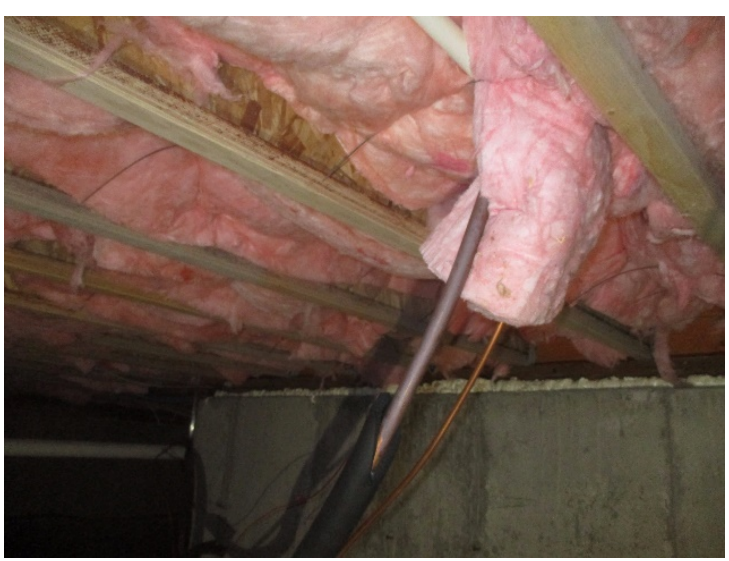

Main water line in the vented crawl space

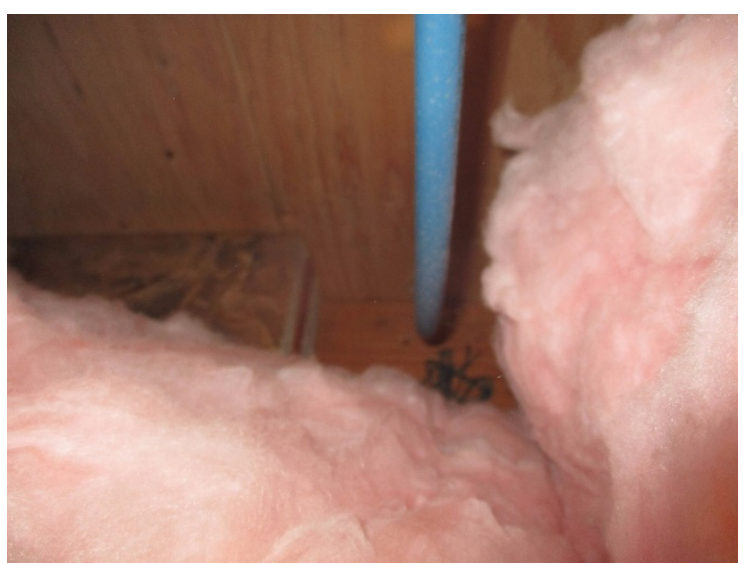




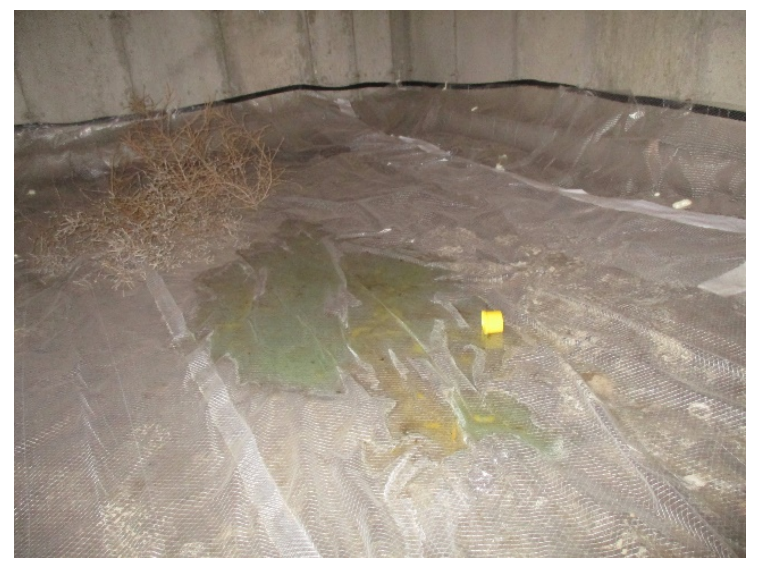

Standing water in the crawl space

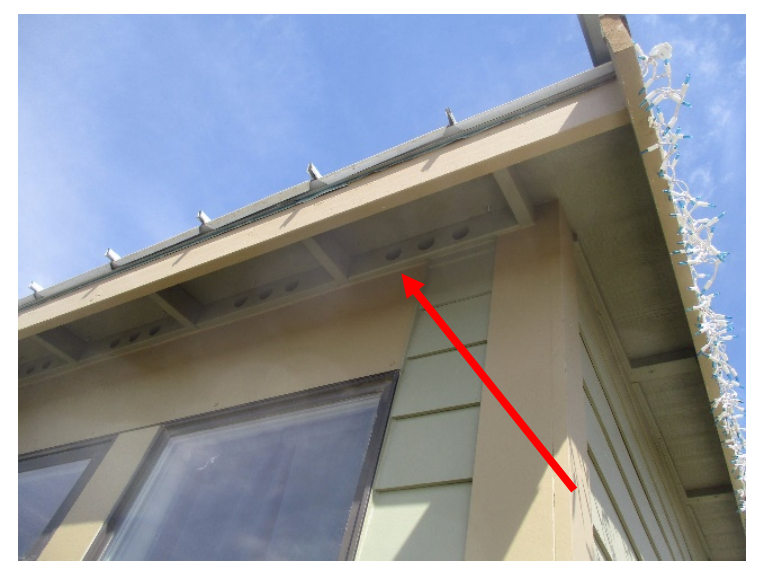

Soffit venting

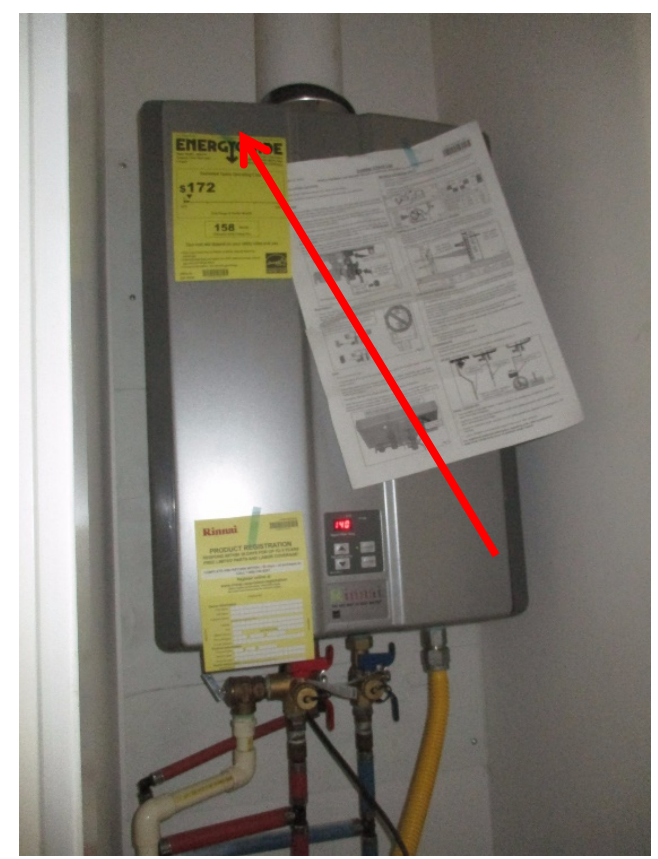

The combustion air supply should be connected at this location

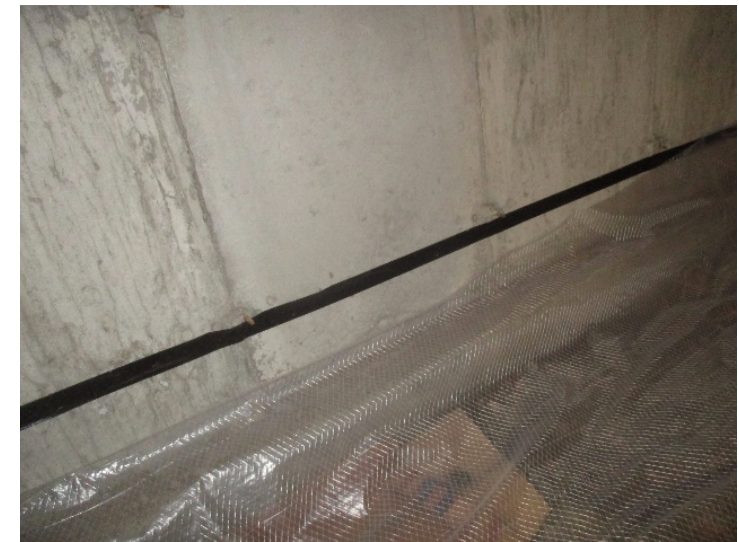

Crawl space liner is not attached to the wall

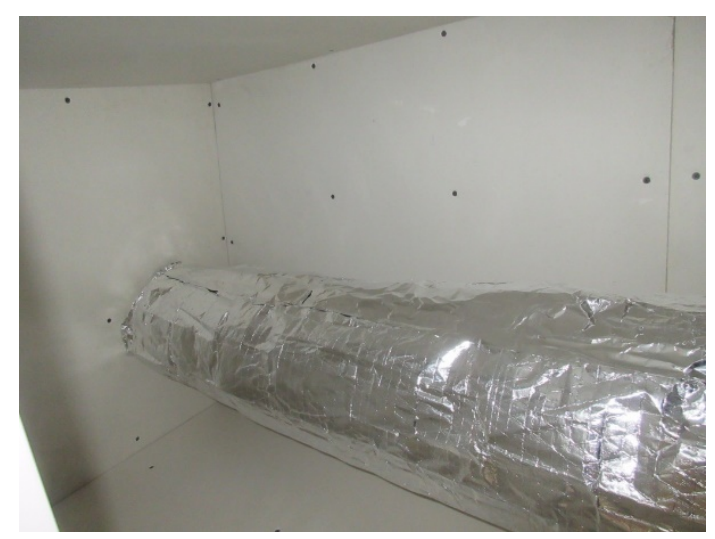

HVAC closet is not air sealed 

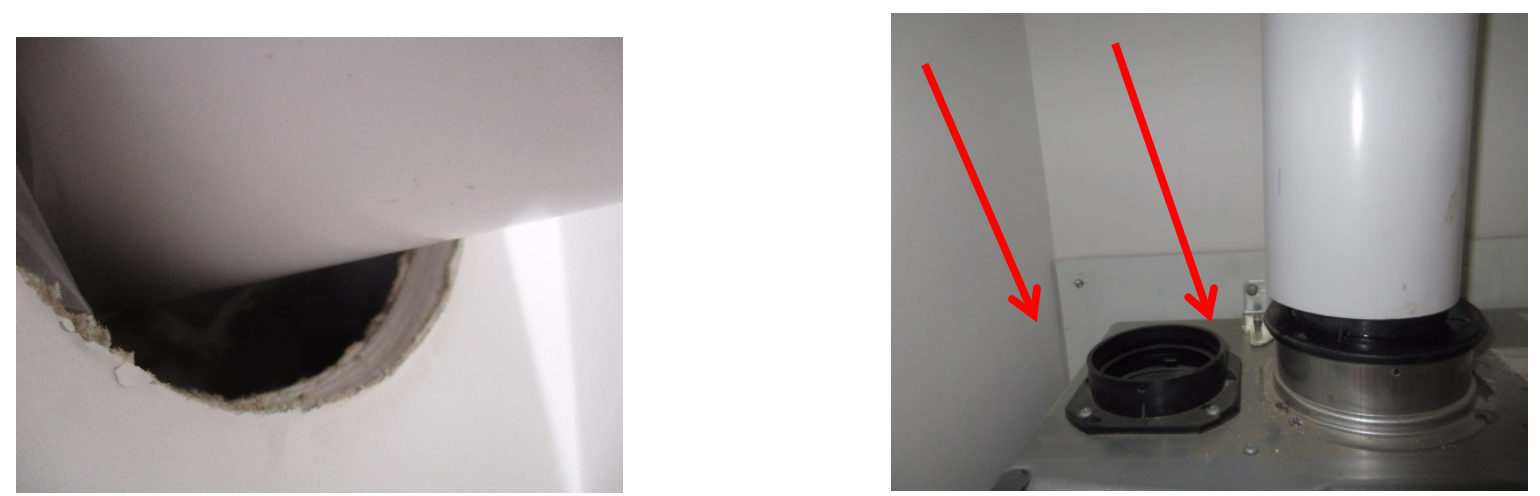

Air leakage from the exhaust flue for the water heater. This leakage is supplying the combustion air for the water heater. The two arrows point to the missing combustion supply and a loose connection between the water heater and the flue.

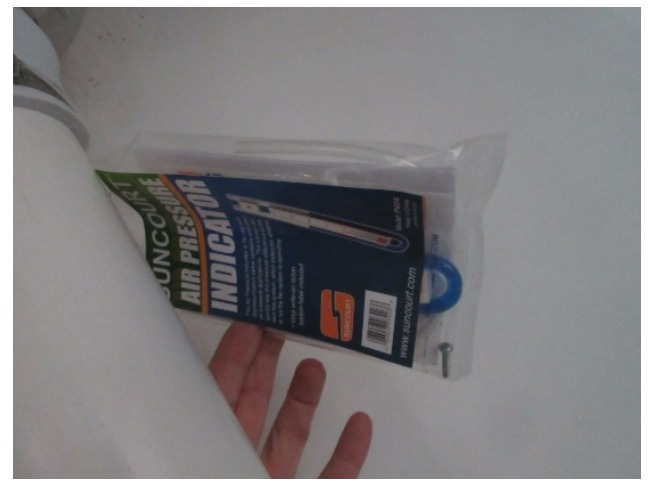

Pressure indicated for radon fan not attached 


\section{Infrared Photos}
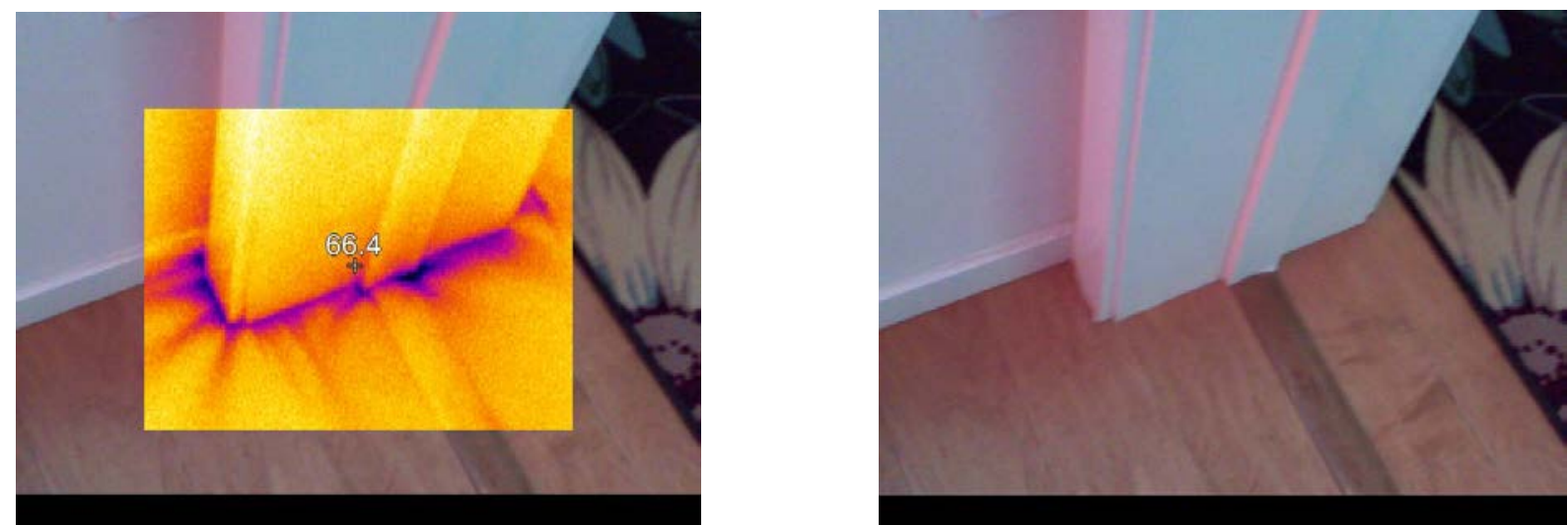

Air leakage from the crawl space. The fan like streaks represent air leakage from the crawl space. The darker the color the colder the air.
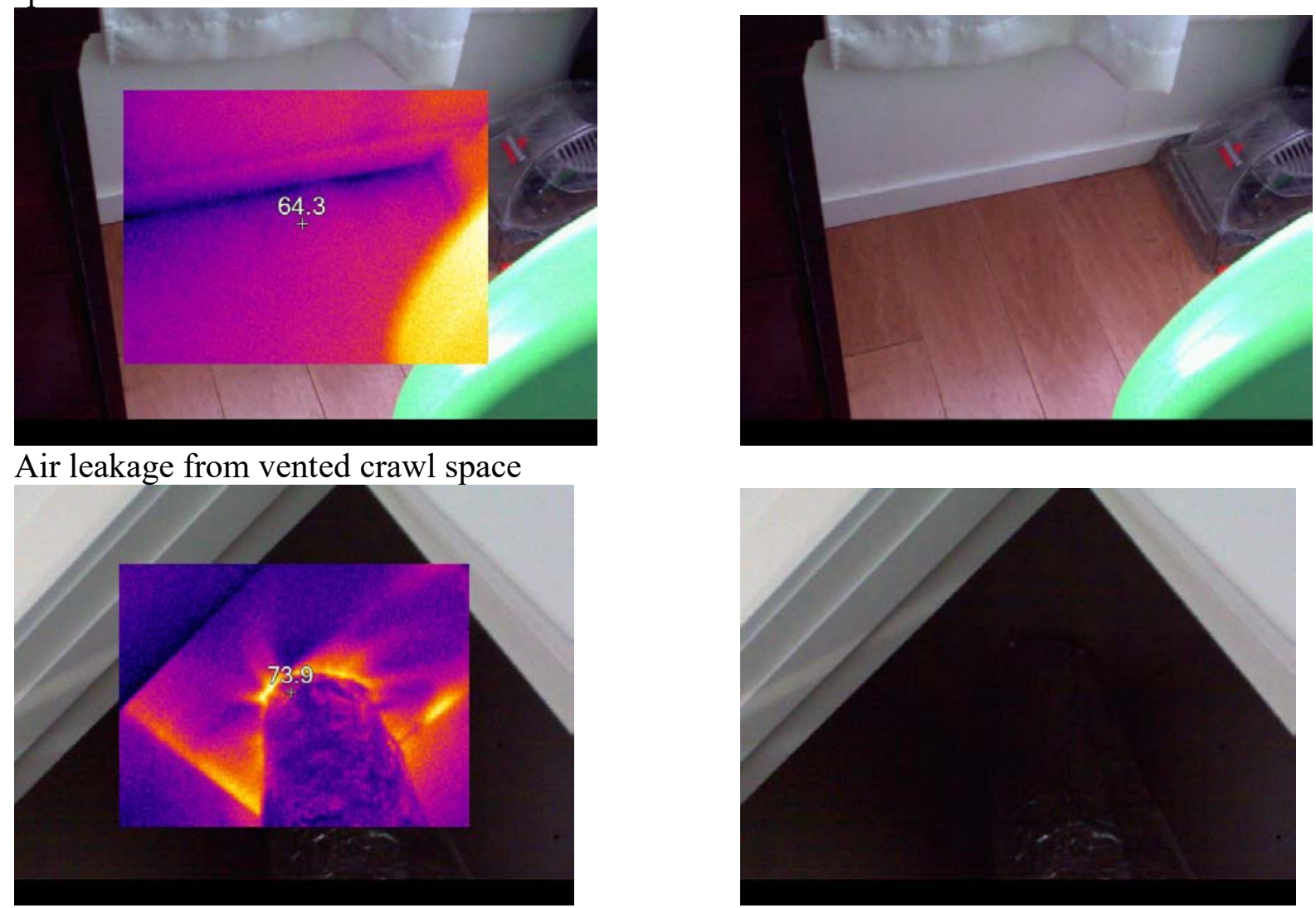

Air leakage in the HVAC closet. This is the supply vent from the air handler in the HVAC closet. The closet drywall and supply vent are not sealed. The yellow streaks are air from the attic that is infiltrating the home. 

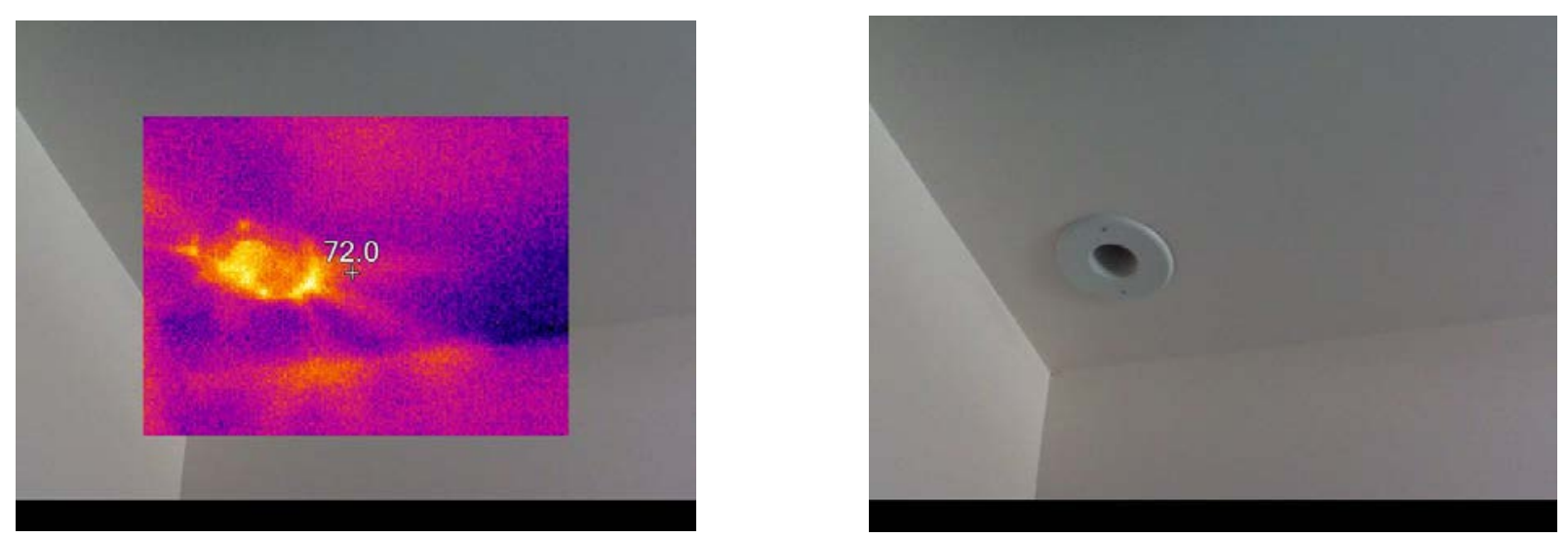

Air leakage from the roof penetration through the edge of the high velocity duct system
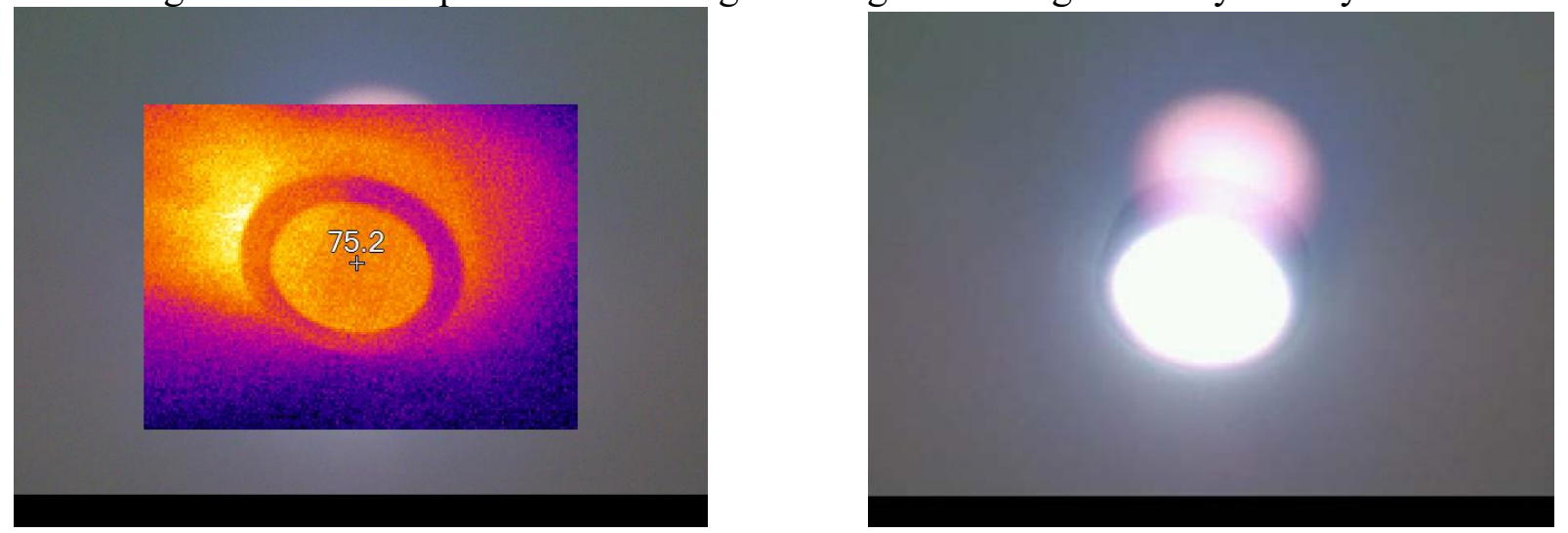

Air leakage around a solar tube
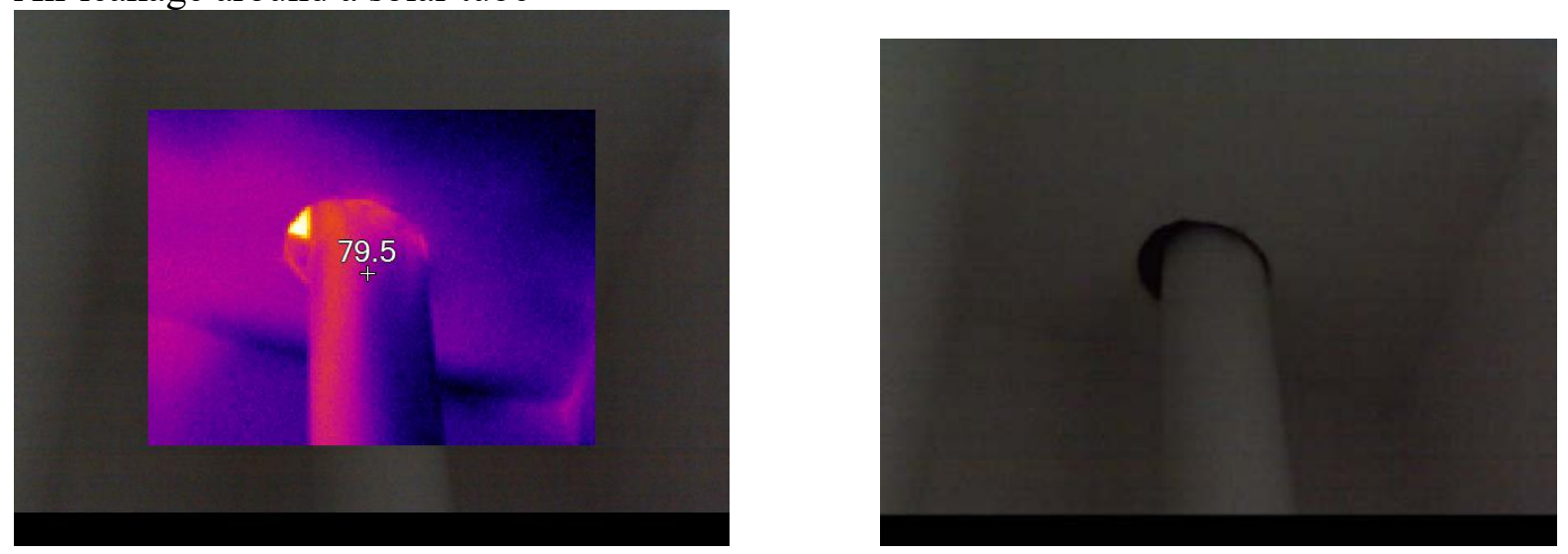

Air leakage at the ceiling where vent from the Rinnai water heater enters the attic assembly. 

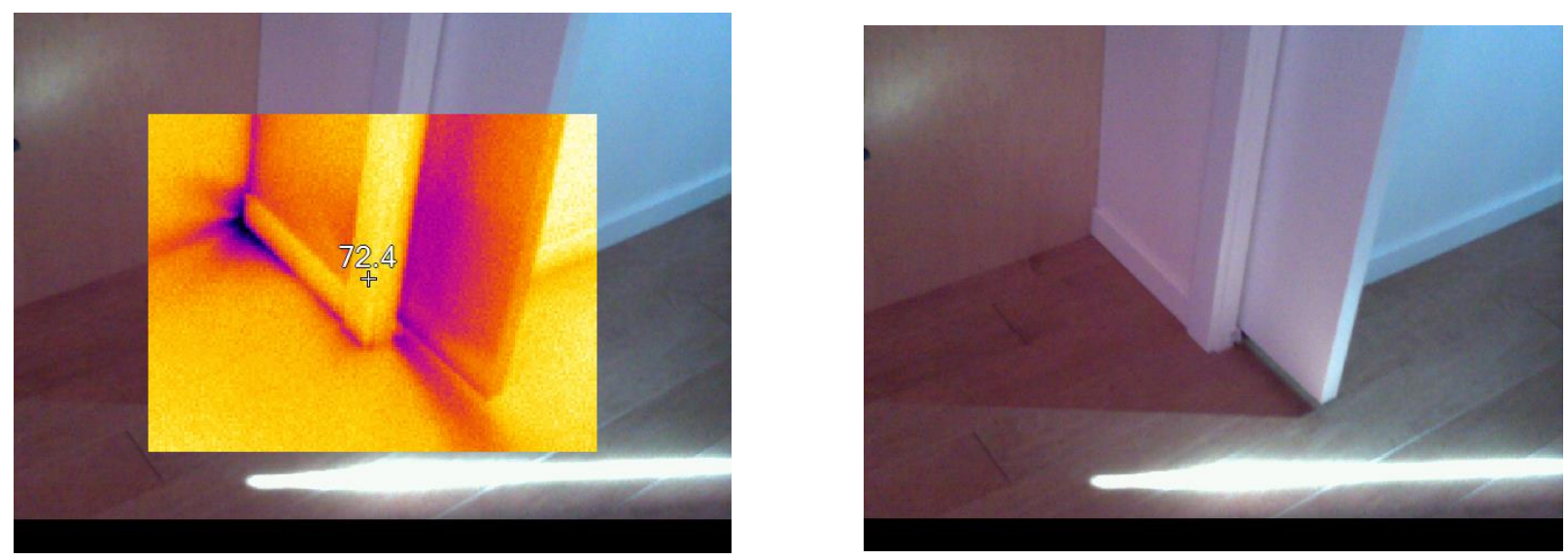

Air leakage at the pocket door 


\title{
Energy Audit Report
}

\author{
Element Model
}

\section{George Washington Street Poplar MT}

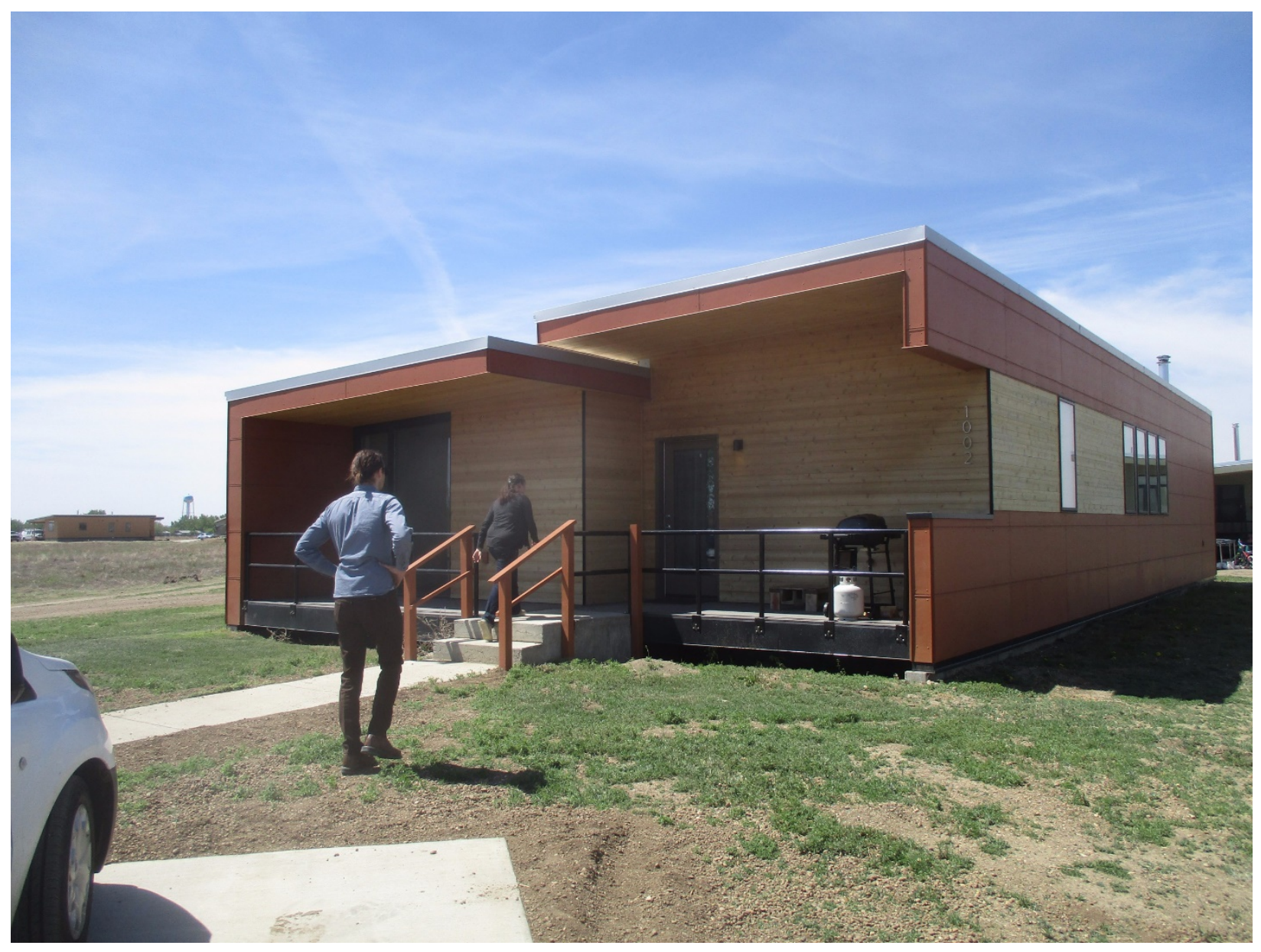

Home Data 
1002 George Washington

\begin{tabular}{|c|c|}
\hline Year Built & 2016 \\
\hline Size & 1479 \\
\hline Direction & East \\
\hline Average Ceiling Height ( $\mathrm{ft}$ ) & 9.5 \\
\hline Blower Door & $658 \mathrm{CFM} \mathrm{ACH}=2.58$ \\
\hline Natural Air Changes & $\mathrm{NACH}=0.15$ \\
\hline Foundation & Vented Crawl R-38 at Floor \\
\hline Vapor Barrier & Good \\
\hline Attic & Vented attic SIP R-45 \\
\hline Walls & R-21 + R-4 Exterior \\
\hline Windows & Fiberglass $U=0.3415 \%$ of wall area \\
\hline Doors & Steel insulated (2) \\
\hline Lighting & 35 CFLs or LEDs \\
\hline Thermostat & $62-70$ degrees \\
\hline Duct Work & High velocity, no evidence of leaks \\
\hline Heating & Water to air heat exchanger \\
\hline & American Standard 4A7A024 2 ton SEER =14- \\
\hline Cooling & 16 \\
\hline Ventilation & Exhaust Only \\
\hline Water Heater & Rinnai RUC 98 \\
\hline Water Heater Efficiency & $92 \%$ \\
\hline DHW Temperature & $140 \mathrm{~F}$ \\
\hline CO Alarms & Yes \\
\hline Ambient CO Level & 0 ppm (PASS) \\
\hline Combustion Air & Sealed Combustion units \\
\hline & $\begin{array}{l}\text { It was not possible to test the CO level in the } \\
\text { flue because the termination point is on the }\end{array}$ \\
\hline DHW CO (air free) ppm & roof \\
\hline Safety Testing & Yes \\
\hline Appliances Energy Star & Yes \\
\hline
\end{tabular}




\section{General Housing Description:}

This home is a single story single family home, which was built as part of the sustainable village in Poplar, MT. The homes were manufactured in Washington State, and moved into place on permanent foundations. The homes utilize a combi unit water heater that provides hot water for DHW and for space heating. The hot water is piped from the water heater to a water to air heat exchanger for space heating. The homes are cooled by a DX central cooling unit. The homes were designed with a vented, unconditioned crawl space and a vapor barrier.

The team found quality workmanship in the homes, but there were issues identified during energy audit that appeared to originate from the final hookup of the homes with the foundation. The vented crawl space did not seem to be sufficiently air sealed or insulated from the living space.

\section{Housing Inspection Notes:}

1. The crawl space is $75 \%$ connected to the home. Vented crawl spaces should be designed and constructed that they are not connected to the home. When testing the pressure in the crawl space with the blower door running at - $50 \mathrm{pa}$, the pressure in the crawl space was $-38 \mathrm{pa}$ which equates to $76 \%$ connection. Air sealing should be done on the interior and outside walls.

2. The HVAC filter should be changed on a regular basis.

3. This home performed the best out of the 5 homes tested.

\section{Recommendations:}

\begin{tabular}{|r|l|}
\hline Recommendations: & Cost \\
\hline 1. Change air filter & $\$ 15.00$ \\
\hline 2. Seal identified air leakage areas & $\$ 600$ \\
\hline $\begin{array}{l}\text { 3. Seal around Rinnai vents where they enter the ceiling/roof } \\
\text { assembly. }\end{array}$ & $\$ 100$ \\
\hline
\end{tabular}

\section{Safety:}

There were no safety issues identified during the energy audit.

\section{Conclusion:}

This style of home performed the best out of the three prefabricated models tested. The SIP panel roofs together with the rigid panel continuous insulation on the outside limit the air leakage. There is a connection from the crawl space to the home which was not originally intended. However, this connection is probably beneficial in the winter time by unintentionally warming the crawl space, which could help prevent the water pipes from freezing. If this type of modular home were placed on a conditioned crawl space, I think it would be a very low energy comfortable home. 


\section{Site Visit Pictures}

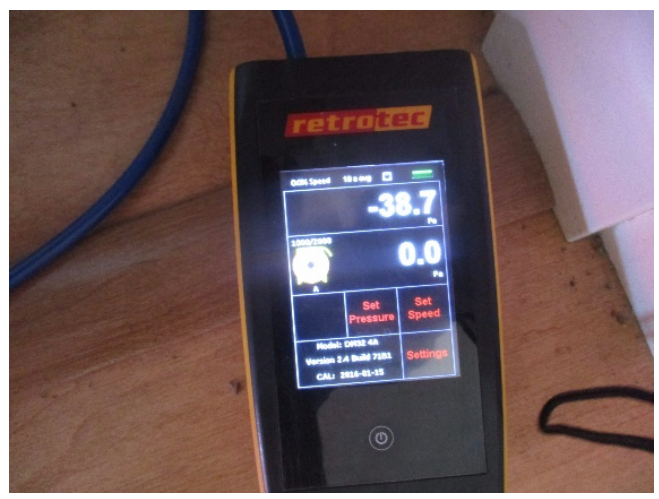

Manometer reading indicating air leakage from the crawl space.

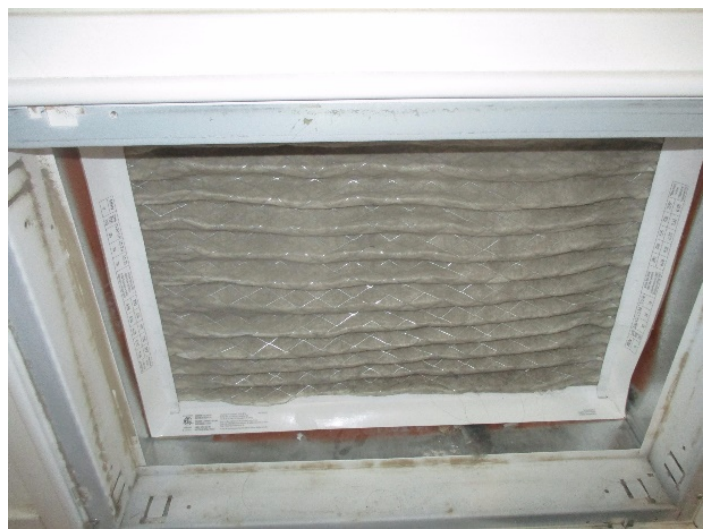

Change HVAC filter every 3 months.

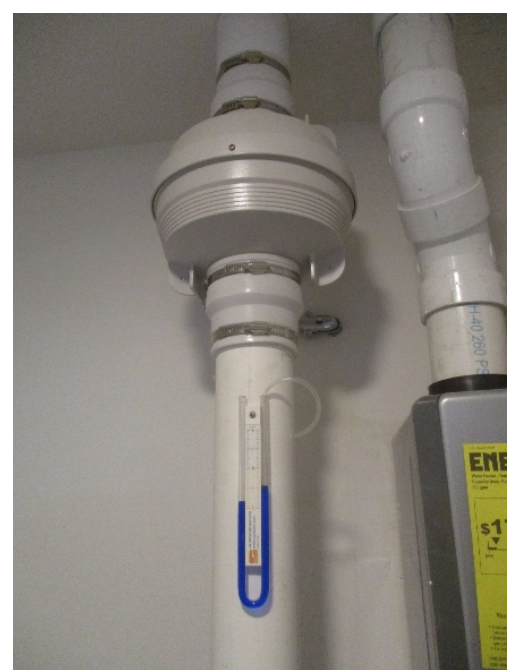

Properly connected radon fan. 


\section{Infrared Photos}
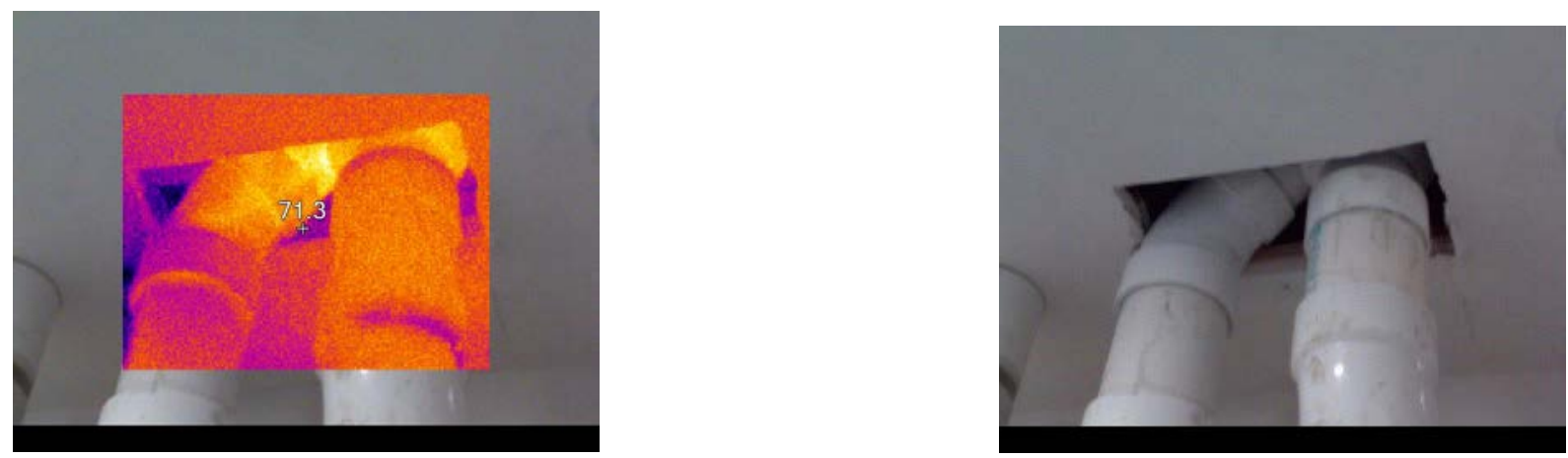

Seal area where Rinnai vents through the roof assembly.
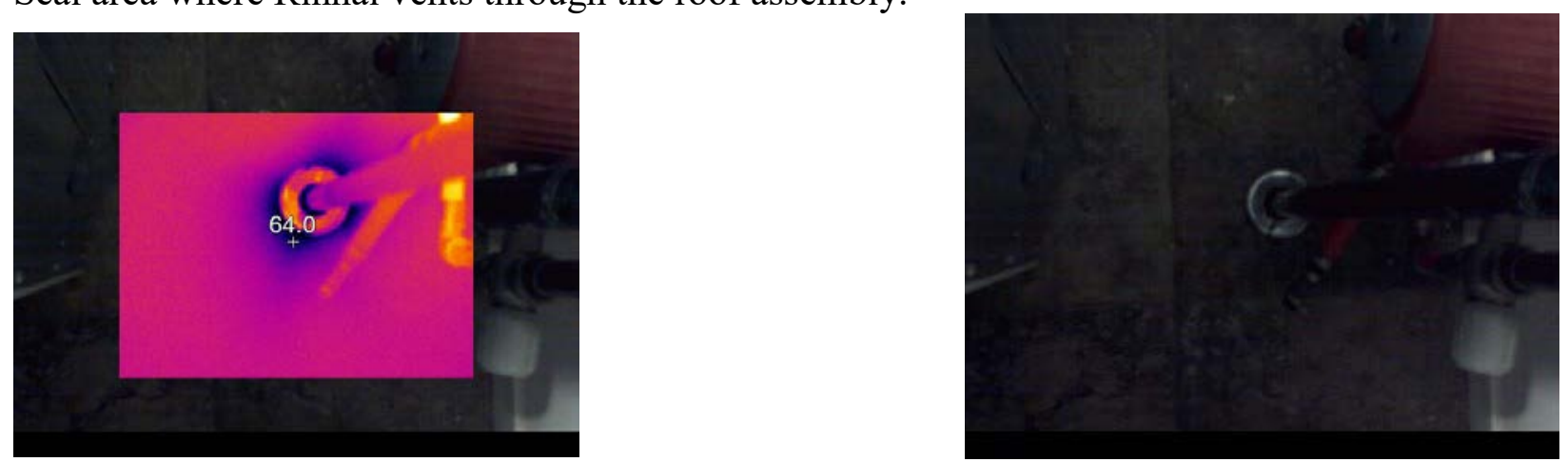

Air leakage from the crawl space in the laundry room. The blue color in infrared photo indicates leakage.
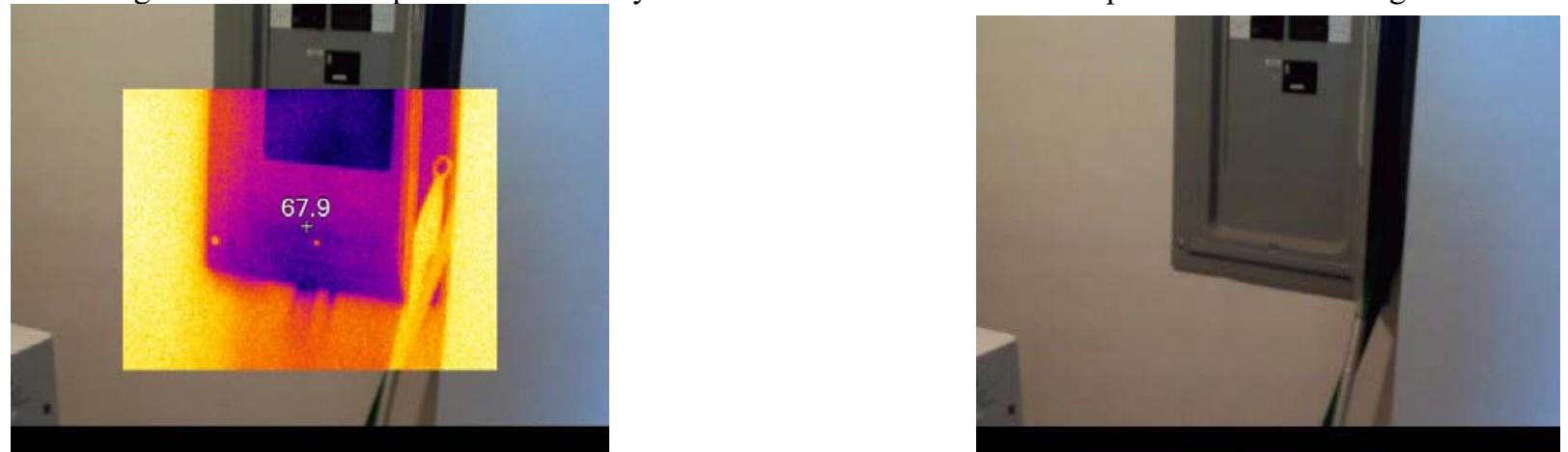

Air leakage at the breaker box, the blue indicates leakage below the panel.
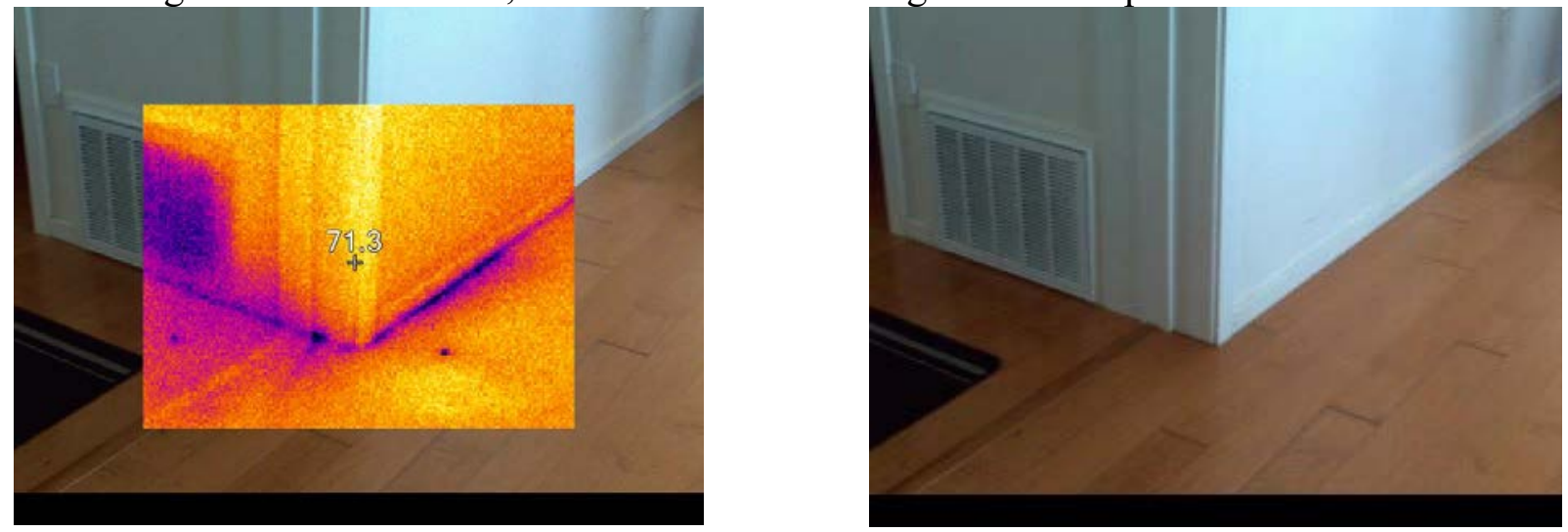
Air leakage from the crawl space and around the filter compartment.
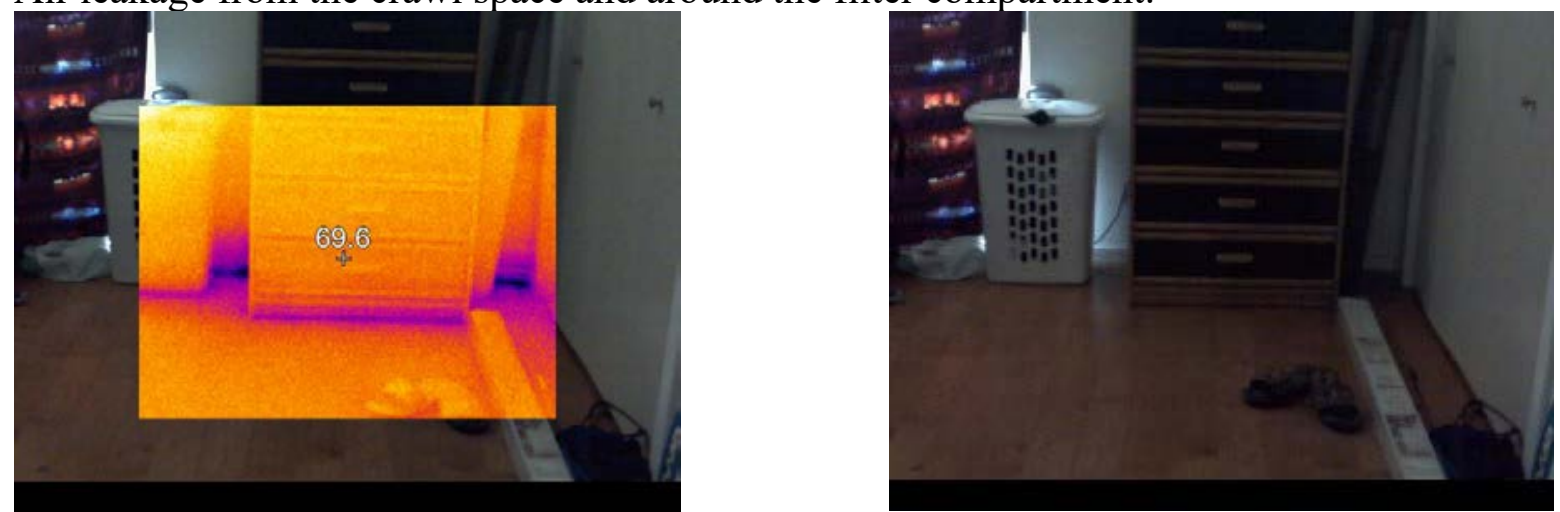

Air leakage from the crawl space at the base of the wall.
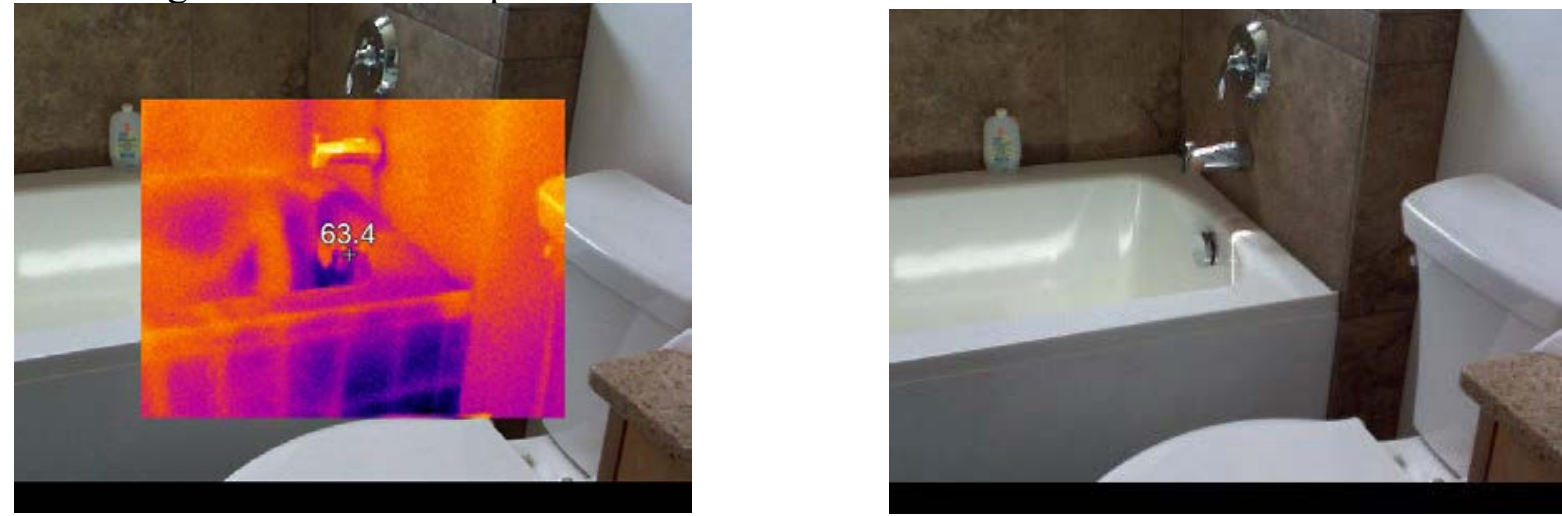

Air leakage around the tub indicates air leakage coming from the crawl space. 


\section{Energy Audit Report \\ 1004 George Washington Ave \\ Option Model \\ Poplar MT}

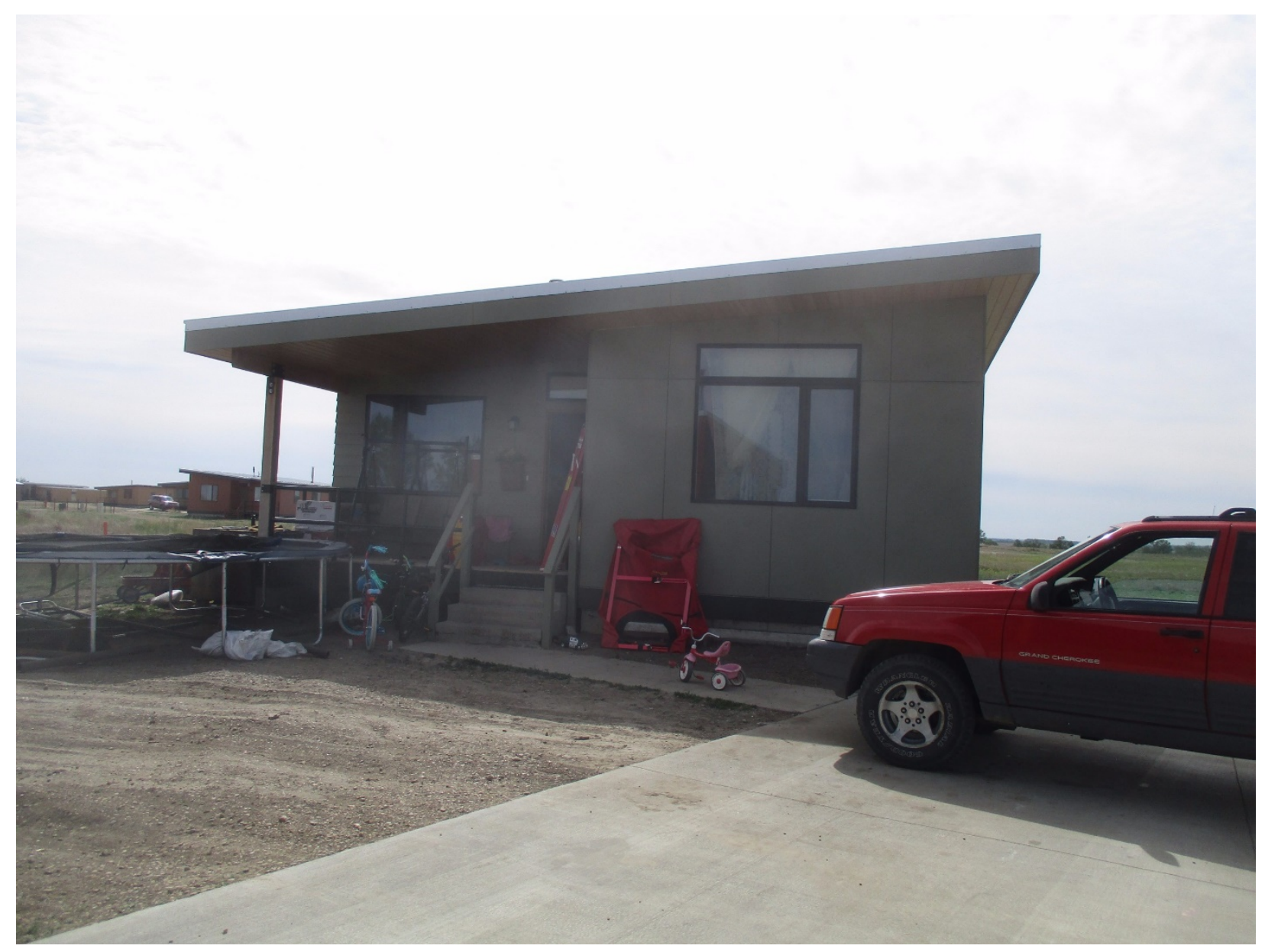

\section{Home Data}




\begin{tabular}{|c|c|}
\hline Address & 1004 \\
\hline Year Built & 2016 \\
\hline Size & 1204 \\
\hline Front Door Direction & East \\
\hline Average Ceiling Height (ft) & 9 Feet \\
\hline Blower Door & $492 \mathrm{CFM} \quad \mathrm{ACH}=2.86$ \\
\hline Natural Air Changes & $\mathrm{NACH}=0.16$ \\
\hline Foundation & Vented Crawl R-38 at floor \\
\hline Vapor Barrier & Fair \\
\hline Attic - structurally insulated panel (SIP) & SIP Estimated at R-45 \\
\hline Walls & R-21 + R-4 Exterior \\
\hline Windows & Fiberglass $U=.34 \quad 15 \%$ of wall area \\
\hline Doors & Steel insulated (2) \\
\hline Lighting & 23 CFLs or LEDs 4 halogen exterior \\
\hline Thermostat & Setpoint $45-48$ degrees* \\
\hline \multicolumn{2}{|c|}{$\begin{array}{r}\text { *The thermostat did not appear to be not programed, it was unclear if the unit was providing } \\
\text { any conditioning. }\end{array}$} \\
\hline Duct Work & High Velocity System \\
\hline Heating & Water to air heat exchanger \\
\hline Cooling & Goodman GSX 160242 Ton SEER = 16 \\
\hline Ventilation & Exhaust only \\
\hline Water Heater Brand (DHW and Space Heating) & Rinnai RUC 98 \\
\hline Water Heater Efficiency & $92 \%$ \\
\hline DHW Temperature & 140 degrees \\
\hline Combustion Air & Sealed Combustion \\
\hline CO Alarms & Yes \\
\hline Ambient CO level ppm & 1 \\
\hline DHW CO (air free) ppm & not tested vent on roof \\
\hline Safety Testing & Pass \\
\hline Appliances Energy Star & Yes \\
\hline
\end{tabular}




\section{General Housing Description:}

This home is a single story single family home, which was built as part of the sustainable village in Poplar, MT. The homes were manufactured in Washington state, and moved into place on permanent foundations. The homes utilize a combi unit water heater that provides hot water for DHW and for space heating. The hot water is piped from the water heater to a water to air heat exchanger for space heating. The homes are cooled by a DX central cooling unit. The homes were designed with a vented, unconditioned crawl space and a vapor barrier. The team found quality workmanship in the homes, but there were issues identified during energy audit that appeared to originate from the final hookup of the homes with the foundation. The vented crawl space did not seem to be sufficiently air sealed or insulated from the living space.

\section{Housing Inspection Notes:}

1. The crawl space ceiling (main level floor) is poorly insulated. The existing R-38 batts are substantially degraded because they are misaligned and falling down in places. This results in cold floors and occupant discomfort.

2. Relocate the water lines to the underside of the insulation so that they are tight against the floor. Currently there are several places where the water lines are exposed to the vented crawl space.

3. Heat tape will be needed on the water line mains if the crawl space is vented.

4. The specifications written by the architect may be different than what was installed.

5. The high velocity system is possibly leaking conditioned air into the unconditioned attic.

6. The rim joist is not properly sealed, it should be sealed to reduce air leakage.

\section{Recommendations:}

There are two possible ways to approach the repairs on this home. The first cost option is the less cost intensive method. This involves keeping the vented crawl space and repairing the construction defects. The second option is more costly, but may be more appropriate for this climate zone. This involves fundamentally changing the design to make the crawl space conditioned. 
Cost Option \#1

\begin{tabular}{|c|c|}
\hline Recommendations: & Cost \\
\hline 1. Relocate Water Lines to underside of insulation & $\$ 1,000$ \\
\hline 2. Seal rim joist where it connects to the home & $\$ 400$ \\
\hline $\begin{array}{l}\text { 3. Re-install and add additional batt insulation in crawl } \\
\text { space }\end{array}$ & $\$ 600$ \\
\hline 4. Educate homeowners on thermostat operation & $\$ 0$ \\
\hline 5. Purchase and install LED exterior lights & $\$ 40$ \\
\hline
\end{tabular}

Cost Option \#2

\section{Recommendations:}

Change crawl space to conditioned crawl, seal the vents in the crawl space, add a sump pump. This option must be discussed with the architect and engineer of the home to be sure it can be done without damaging the structure

\section{Safety:}

No safety issues were observed.

\section{Conclusion:}

The Option model prefabricated home seems to perform fairly well with the exception of the water lines freezing in the winter time. The homes are tight and have exhaust only ventilation to bring fresh air into the home during the winter time. The homeowners are comfortable but are concerned about the water supply lines freezing in the wintertime. The high-water table necessitates that the crawl space need to be vented if a sump pump is not installed. The home would perform even better if the crawl spaces were conditioned similar to the other tax credit homes that also contain a heat recovery ventilator (HRV). 


\section{Site Visit Pictures}
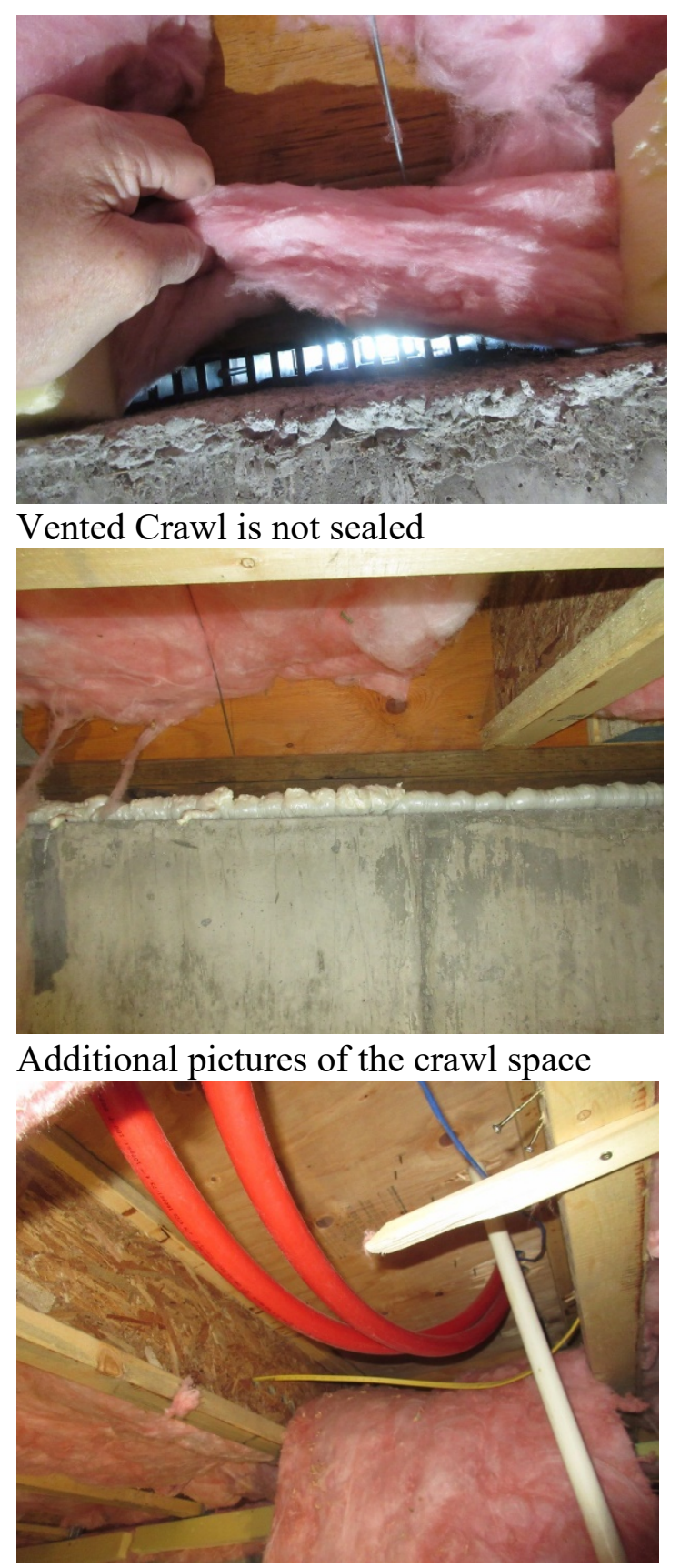

Exposed water lines in a vented crawl space.
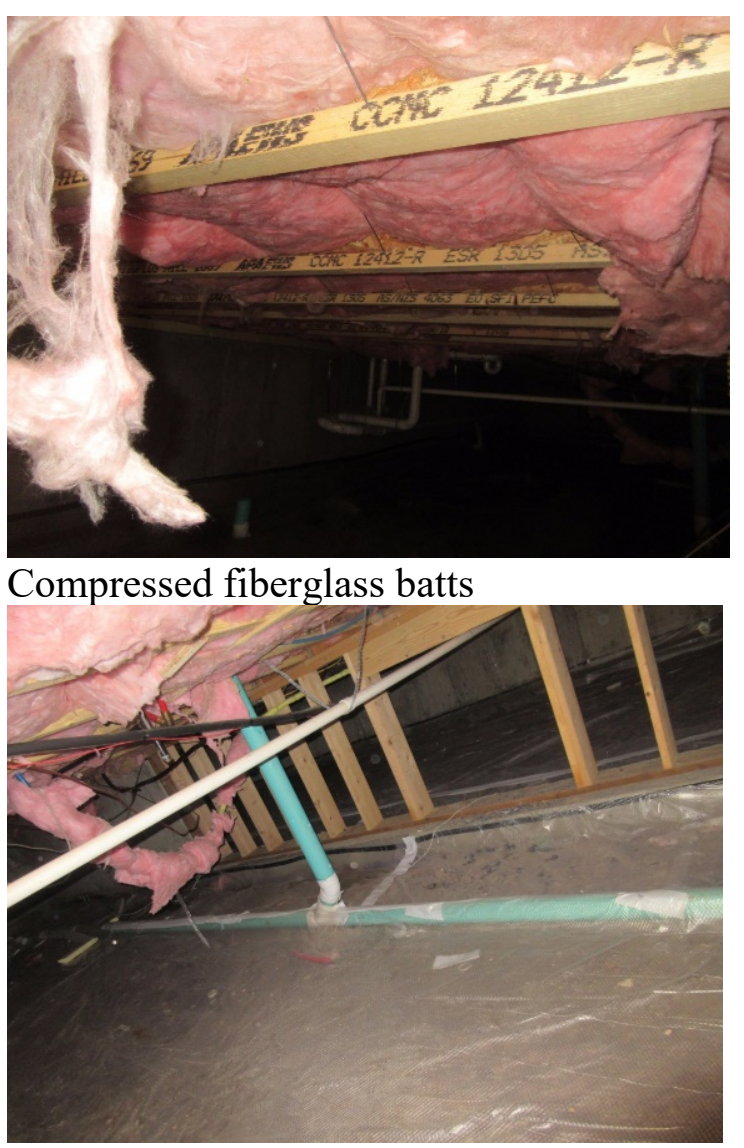

Poorly insulated pipes, and radon pipe

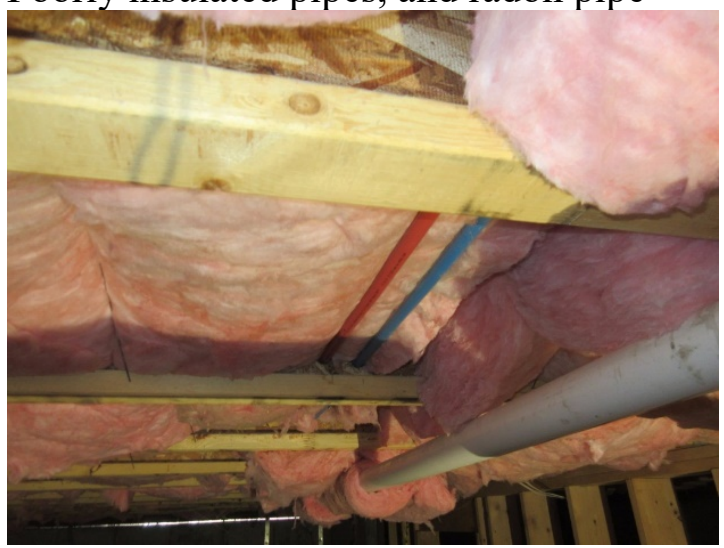

These water line are exposed to freezing temperatures 


\section{Infrared Photos}
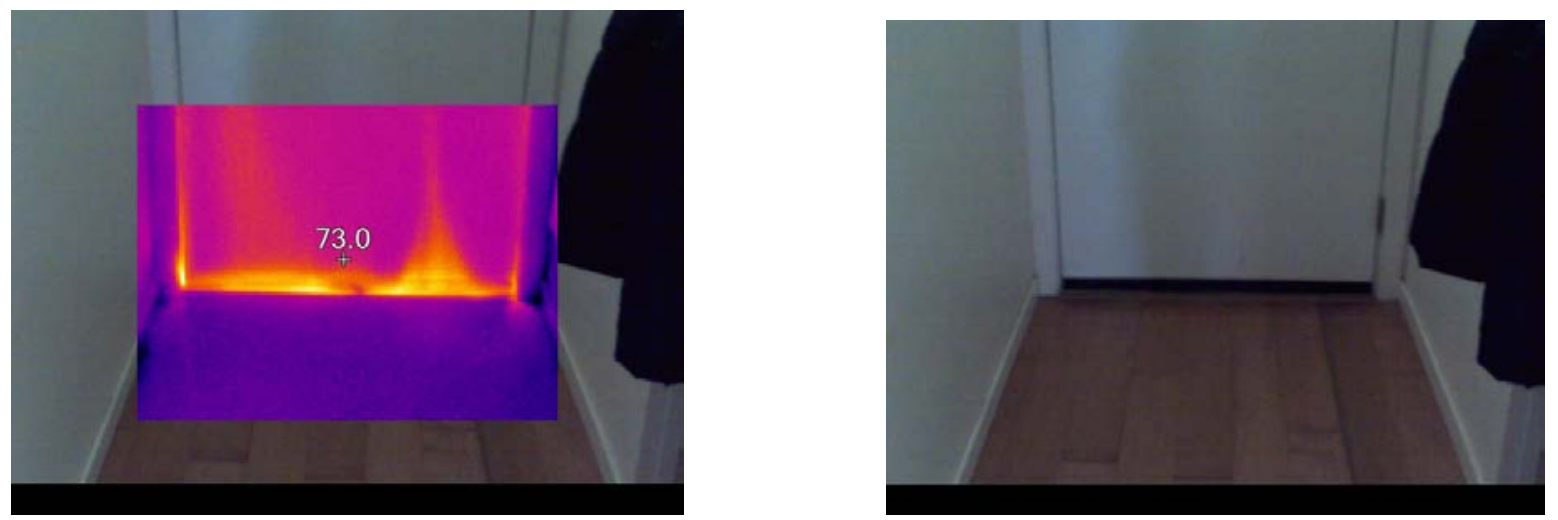

Air leakage at the door sweep, the yellow colors show the cold air seeping in.
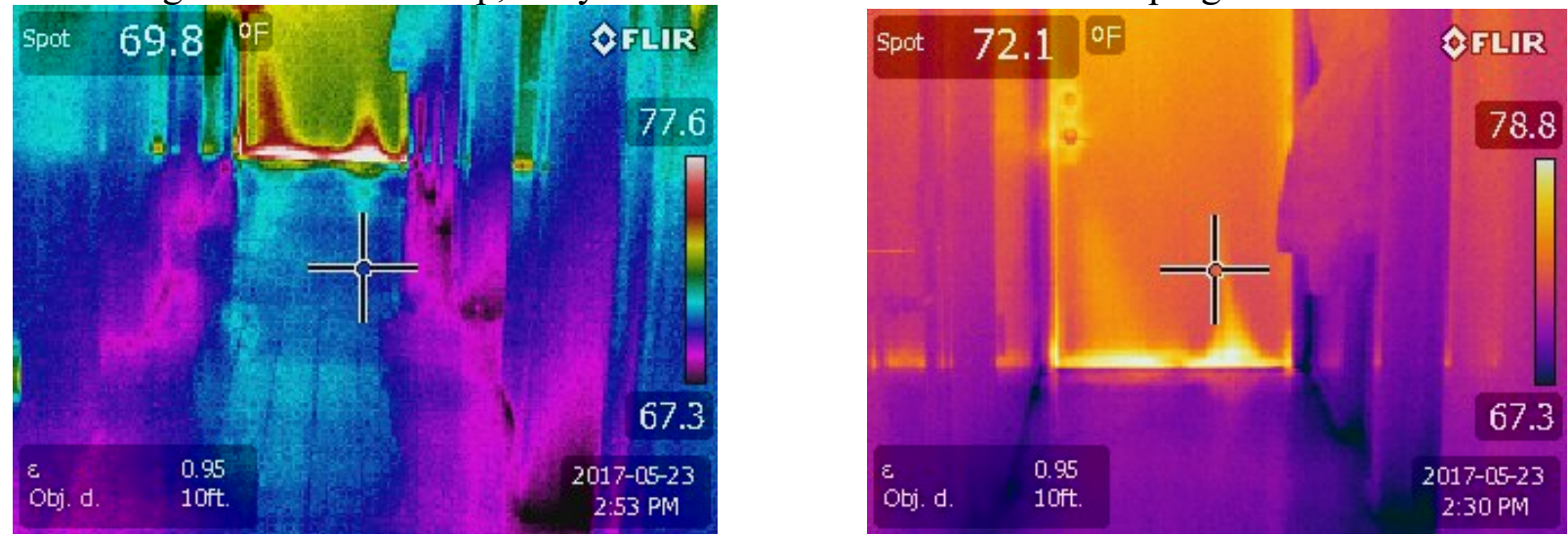

Air leakage at the door sweep and from the crawl space.
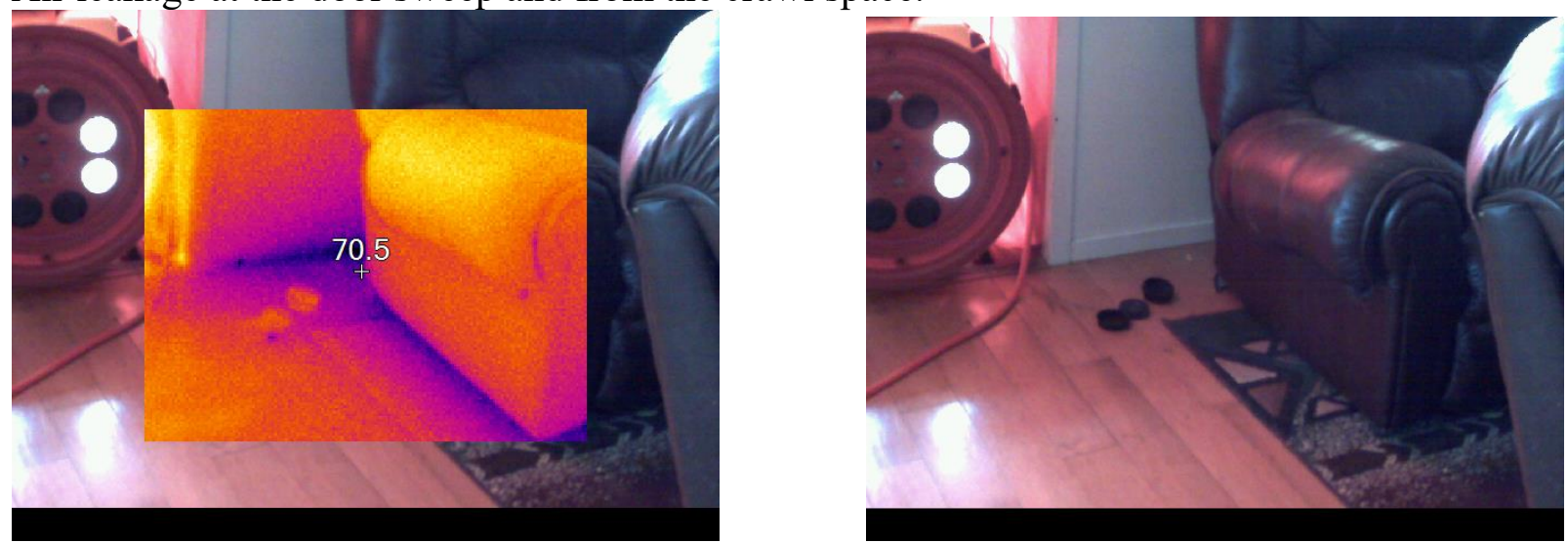

Air leakage from the crawl space. In the winter time, the occupants said the floors get cold. 

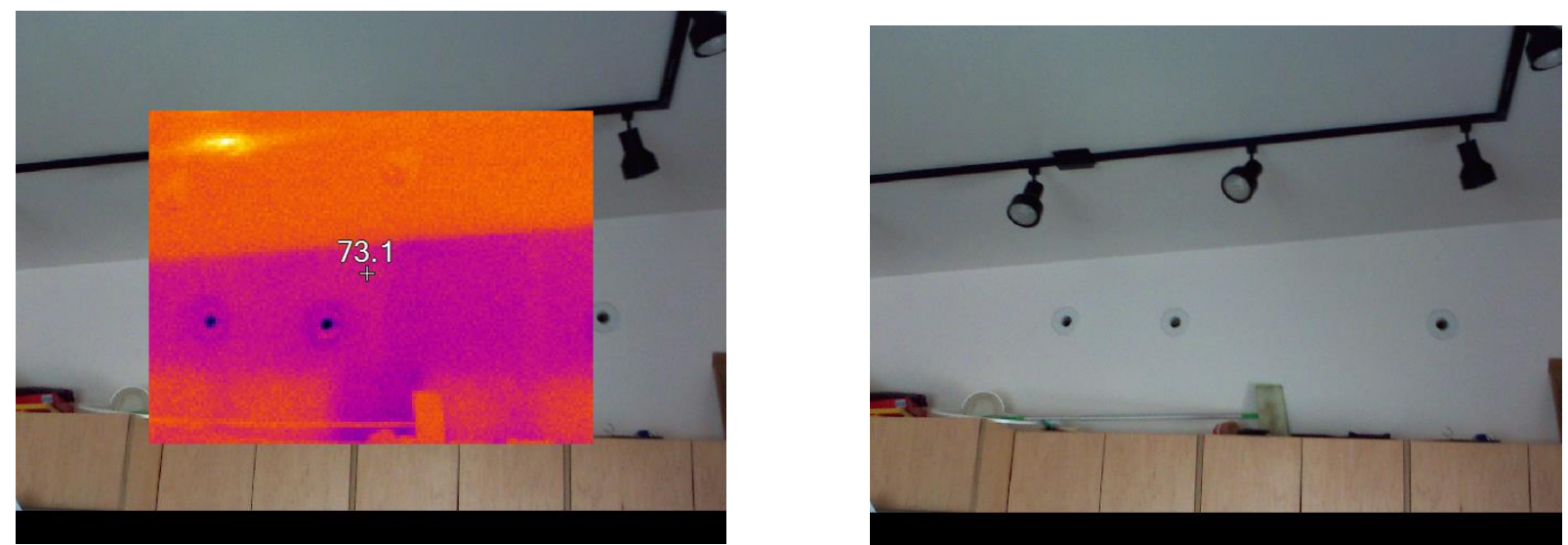

The constant temperature of the back wall indicates there is likely air leakage from the high velocity air distribution system into the cavity behind the wall. 


\section{Energy Audit Report 907 Choke Cherry Poplar MT}

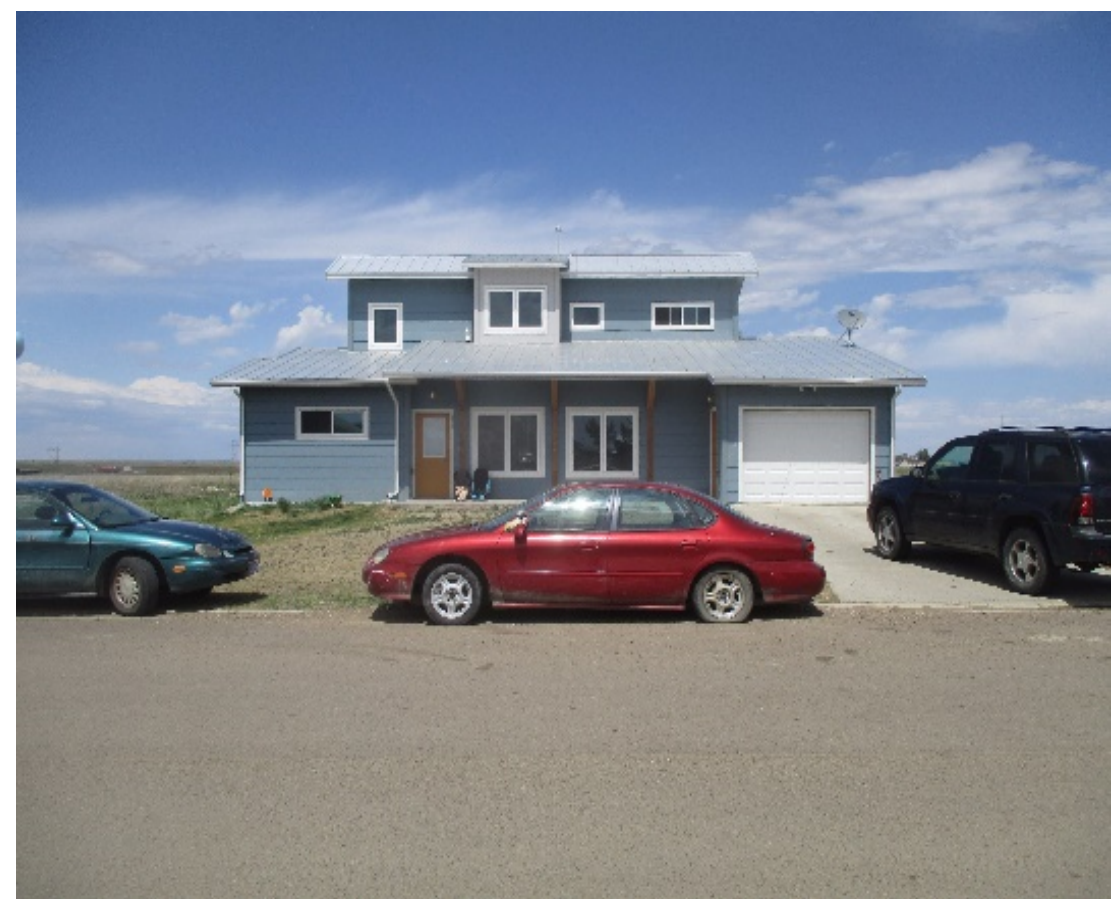

Home Data 
Address

907 Choke Cherry

\begin{tabular}{|c|c|}
\hline Year Built & 2012 \\
\hline Size & 1,650 \\
\hline Direction & South \\
\hline Average Ceiling Height & 9 \\
\hline Blower Door & $4,114 \mathrm{CFM} \quad \mathrm{ACH}=16.62$ \\
\hline Foundation & Conditioned Crawl R-10 at exterior wall \\
\hline Vapor Barrier & Good- Excellent rigid board under barrier \\
\hline Attic & R $39-45$ \\
\hline Walls & $\mathrm{R}-19$ \\
\hline Windows & Vinyl Low $E \quad U=.40$ \\
\hline Doors & Steel Insulated (2) \\
\hline Lighting & 42 CFLs or LEDs \\
\hline Thermostat & 70 Heat \\
\hline Duct Work & Substantial Plenum Return Leaks \\
\hline Heating & Goodman 92\% AFUE \\
\hline Cooling & Whole House Fan \\
\hline Ventilation & Fantec HRV \\
\hline Water Heater & 50 gallons $A O$ Smith $E F=.56$ \\
\hline Domestic Hot Water (DHW) Temperature & 145 degrees \\
\hline $\begin{array}{l}\text { Combustion Air (Outside Air used for } \\
\text { combustion appliances) }\end{array}$ & Yes (water heater only) \\
\hline CO Alarms & No \\
\hline Ambient CO Level & 0 ppm \\
\hline $\begin{array}{l}\text { DHW CO (air free) Standard developed by } \\
\text { Building Performance Institute that measures } \\
\text { the carbon monoxide level in the flue. The } \\
\text { maximum allowable level is } 200 \text { ppm. }\end{array}$ & $16 \mathrm{ppm}$ \\
\hline Safety Testing & Pass \\
\hline Appliances & Energy Star \\
\hline
\end{tabular}




\section{General Housing Description:}

This home is a two story single family home that was designed well for this climate zone. The home utilized a whole house fan for cooling in the summer forced air natural gas heating in the winter. A heat recovery ventilator is used to bring fresh air into the home. The conditioned crawl space is purposely heated and contains a sump pump to remove water as the water table is close to the surface. This combination of building and ventilation methods works very well. During the energy audit, substantial leakage was found that is preventing the systems from working together effectively.

The team found quality workmanship on most aspects of the home, but found a couple of problems. The list of corrections is located in the Housing Inspection Notes section directly below.

\section{Housing Inspection Notes:}

1. Excess ventilation in the attic that has caused wind washing of the insulation resulting in varying thickness of insulation and less than optimal performance.

2. Corrosion on the furnace possibly caused by the flue gasses condensing by the cold air entering the return plenum from the break in the air barrier in the garage. The furnace should be checked for possible additional corrosion after the corrective action listed in the recommendations section.

3. DHW temperature is $145^{\circ} \mathrm{F}$. Water only has to be between 120 and 125 degrees for sanitation purposes. Lowering the water temperature makes it easier for the water heater to maintain its temperature and uses less natural gas while reducing standby losses. Simply measure the water temperature with a cooking thermometer and adjust the water heater temperature control until it reaches 120 degrees.

4. Air leakage on the home is high with a blower door reading of 4,114 cfm. This equate to an $\mathrm{ACH}$ of 16, or a NACH of 1.08. A tight home has an ACH of 3 and an NACH of .25.

5. A home can benefit greatly from air sealing. Air sealing will keep the conditioned air that is heated or cooled from escaping to the outside as well as keeping unwanted outside air from getting into the home. Air sealing increases comfort and reduces energy use, which makes heating or cooling the home less expensive. Air sealing also reduces wear and tear on the heating and cooling systems by reducing the amount of work the systems have to do to keep the home comfortable. This home has an air exchange rate of $108 \%$ every hour. The home can be safely air sealed to an air exchange rate of $25 \%$ - $35 \%$ every hour without installing mechanical ventilation. This home has mechanical ventilation and therefore has no lower limit for air sealing. The latest studies have proven that air tight homes with mechanical ventilation are more effective at increasing the overall health and lifespan of the average person. Mechanical ventilation is preferable to natural ventilation because natural ventilation does not filter or control the source of air that is entering the home. This air can come from attics, basements, and crawlspaces, which may contain a variety of harmful pollutants. Mechanical ventilation brings air into the home from directly outside and can be fitted with filtration systems to increase the purity of the outside air entering the home. The benefits of controlled ventilation far outweigh the small electrical use to operate the system.

6. A conditioned unvented crawl space with a sump pump to remove water works well in this climate zone. 


\begin{tabular}{|c|c|}
\hline Recommendations: & Cost \\
\hline $\begin{array}{l}\text { 1. Redo air barrier in the garage so } \\
\text { that the return air plenum is not } \\
\text { connected to the outside. The } \\
\text { plastic originally used is not } \\
\text { adequate for an air barrier. It } \\
\text { should be changed to a rigid barrier. }\end{array}$ & $\begin{array}{l}\$ 200-\$ 300 . \text { Material cost is small and } \\
\text { it is mostly labor. }\end{array}$ \\
\hline $\begin{array}{l}\text { 2. Remove or relocate insulation in } \\
\text { the kitchen living room area of the } \\
\text { home and air seal the ceiling, } \\
\text { before replacing the insulation. }\end{array}$ & $\begin{array}{l}\$ 1,000 \text { all labor. This is a labor- } \\
\text { intensive project. If additional insulation } \\
\text { is needed an additional } \$ 800 \text { should be } \\
\text { added to the total }\end{array}$ \\
\hline 3. Insulate the attic hatch. & $\$ 50-$ a simple project \\
\hline 4. Clean HRV filter on a regular basis. & 1 hour labor for the maintenance crew \\
\hline $\begin{array}{l}\text { 5. Install CO detectors in each } \\
\text { bedroom and central hallway }\end{array}$ & $\$ 35$ per CO detector \\
\hline 6. Lower hot water temperature & $\$ 0$ \\
\hline 7. Replace furnace if necessary & $\$ 3,200$ \\
\hline
\end{tabular}

\section{Safety:}

1. Water Heater CO PPM 16 Air free - Meets Standard

2. Water Supply line is resting against the flue pipe on the DHW. It is possible that the excess heat from the flue could damage the water line causing it to rupture and flood the home.

\section{Conclusion:}

Overall, the home seemed to be well designed. For future construction, the team would recommend testing of the home tightness (blower door) before final construction sign off. The home should achieve a reading of 3 air changes per hour. (ACH). For a 2,000 square foot home with an average of a 9 foot ceiling the blower door reading should be no greater than $900 \mathrm{cfm}$. The math formula to calculate the number of air changes per hour from a blower door test is as follows:

Air Changes per Hour $(A C H)=\frac{\text { Cubic Feet Per Minute }(C F M)}{\text { Cubic Volume of Home }} \times \frac{60 \text { minutes }}{\text { hour }}$

With this level of house tightness mechanical ventilation by the installation an HRV is necessary to maintain a healthy indoor air quality.

The team would recommend closed combustion on the water heater. The team would recommend increasing insulation values in the homes from 38 to 49 in the ceiling, R-19 to R-21 in the walls, and designing as close to passive house standards. The Cold Climate Housing Research Center. (http://www.cchrc.org/publications) has publications that include design best practices and good ideas for efficient design. The team would recommend more occupant education on operation of the whole house fan. 
The IECC 2015 prescriptive measures for the building shell in climate zone 7 are as follows:

TABLE R402.1.2

INSULATION AND FENESTRATION REQUIREMENTS BY COMPONENT ${ }^{\sharp}$

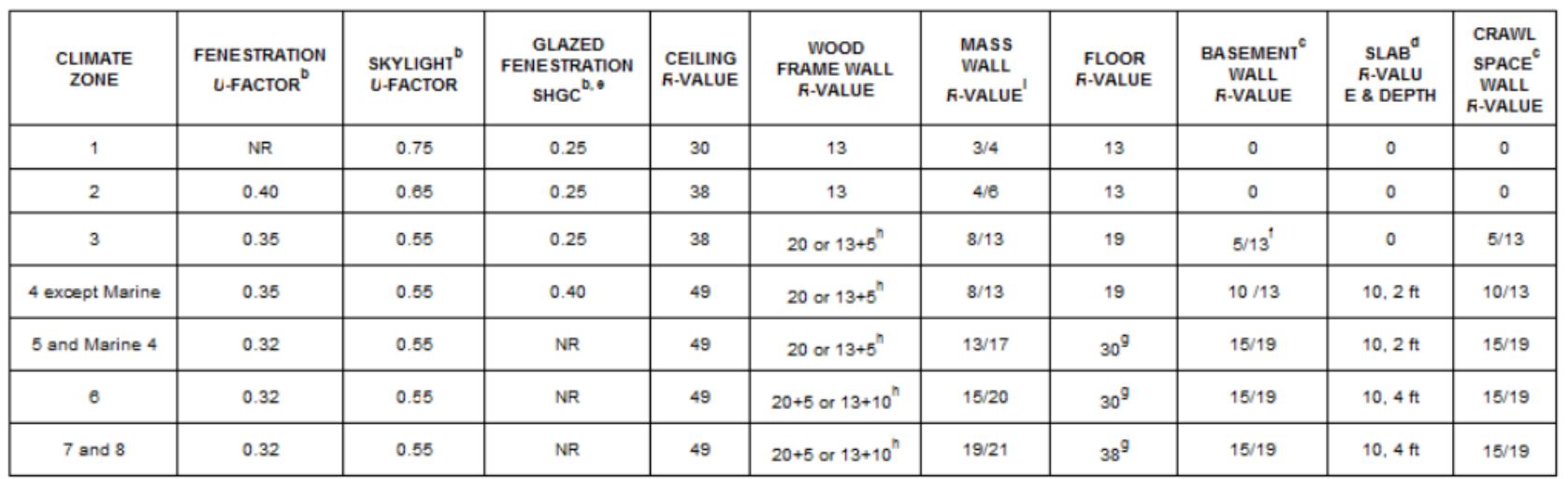




\section{Site Visit Pictures}
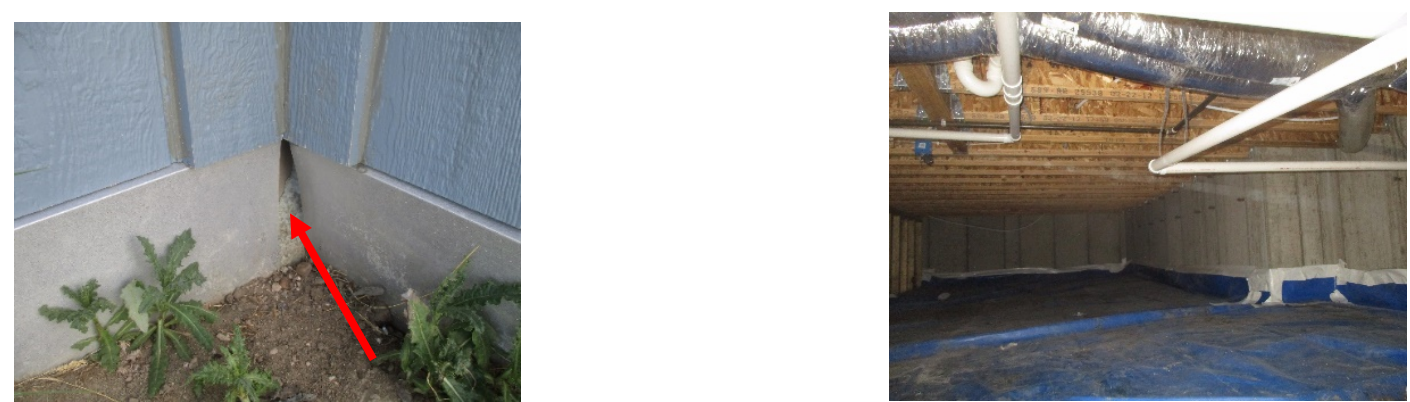

Left: Rigid Insulation has been pushed under the home, suggest replacing.

Right: Conditioned Crawl space.

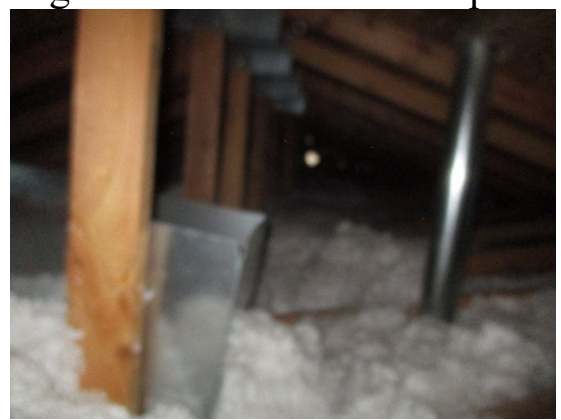

\section{Attic Insulation}

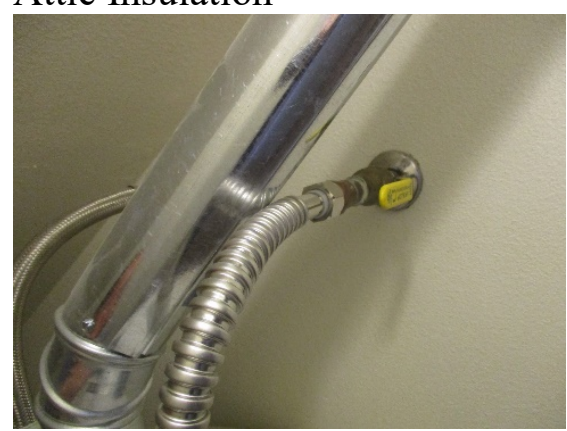

Water Supply Line resting against flue

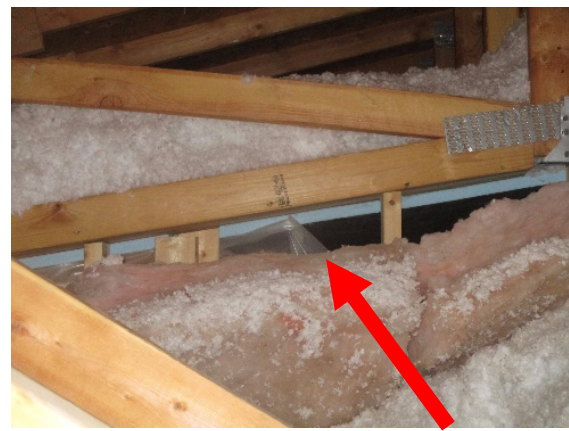

Left: Failed air barrier. This piece of plastic should be replaced with rigid form or some other more robust material. Right: Return air pathway.

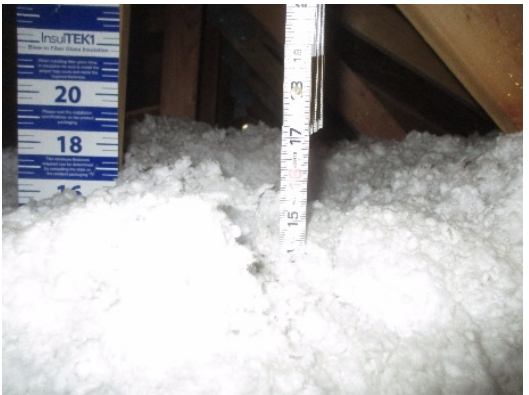

\section{Attic Insulation}

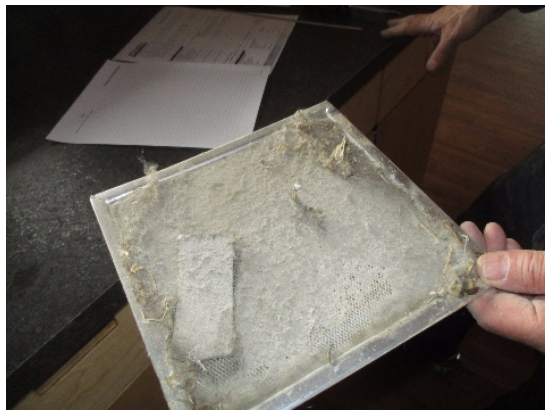

Dirty HRV Filter

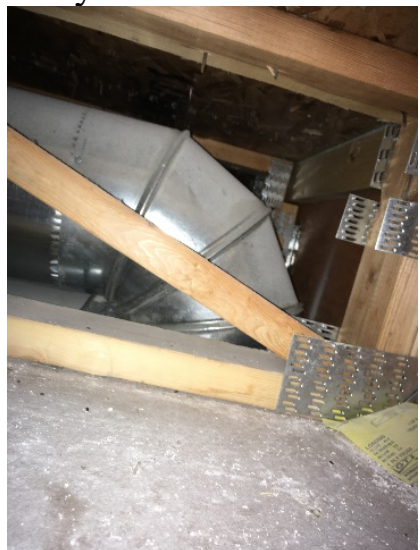




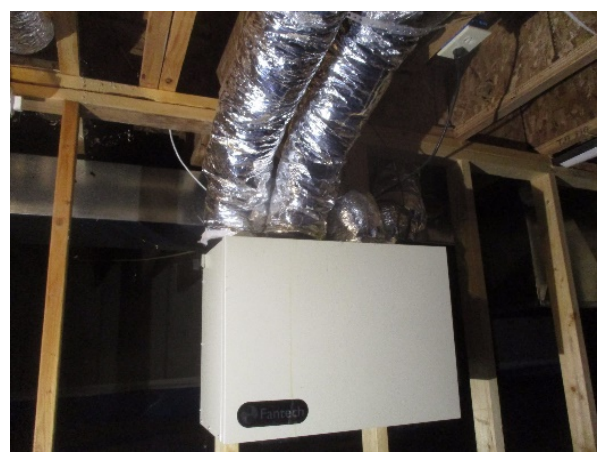

HRV Unit in crawl space

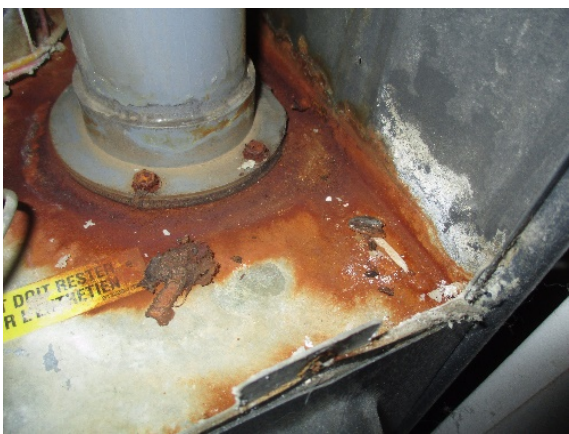

Corrosion on furnace 


\section{Infrared Photos}

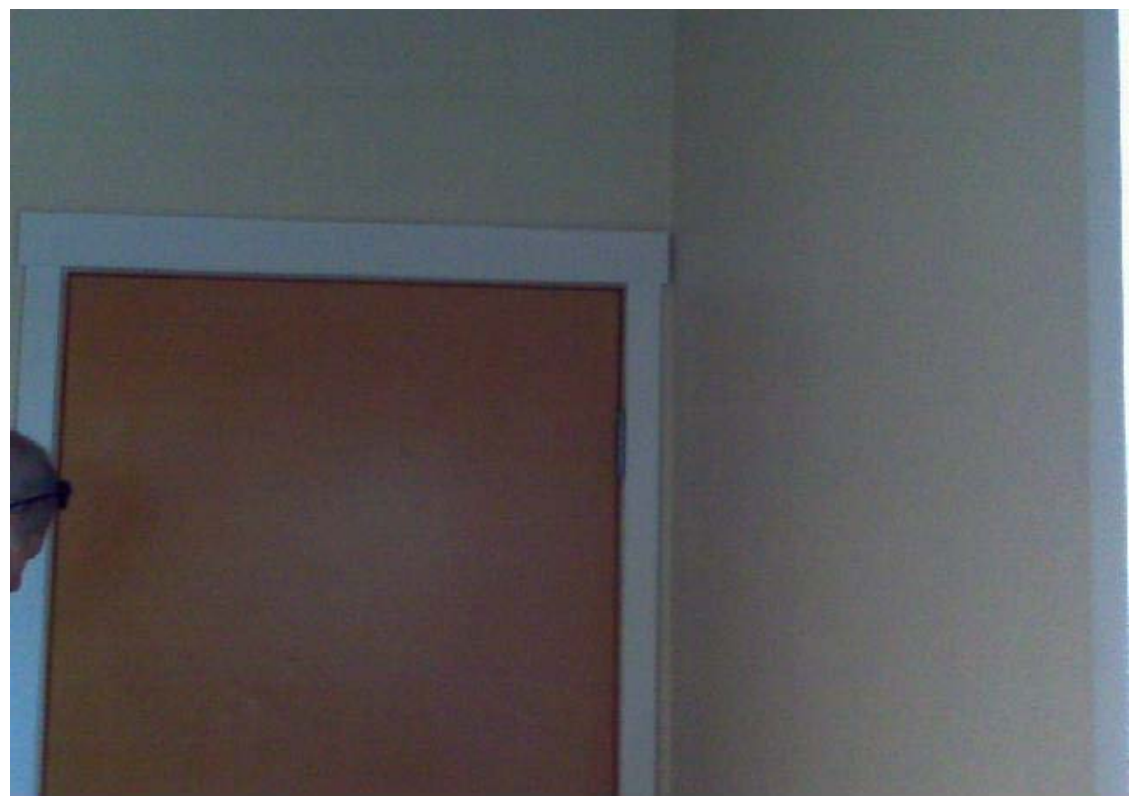

Front door of the home.

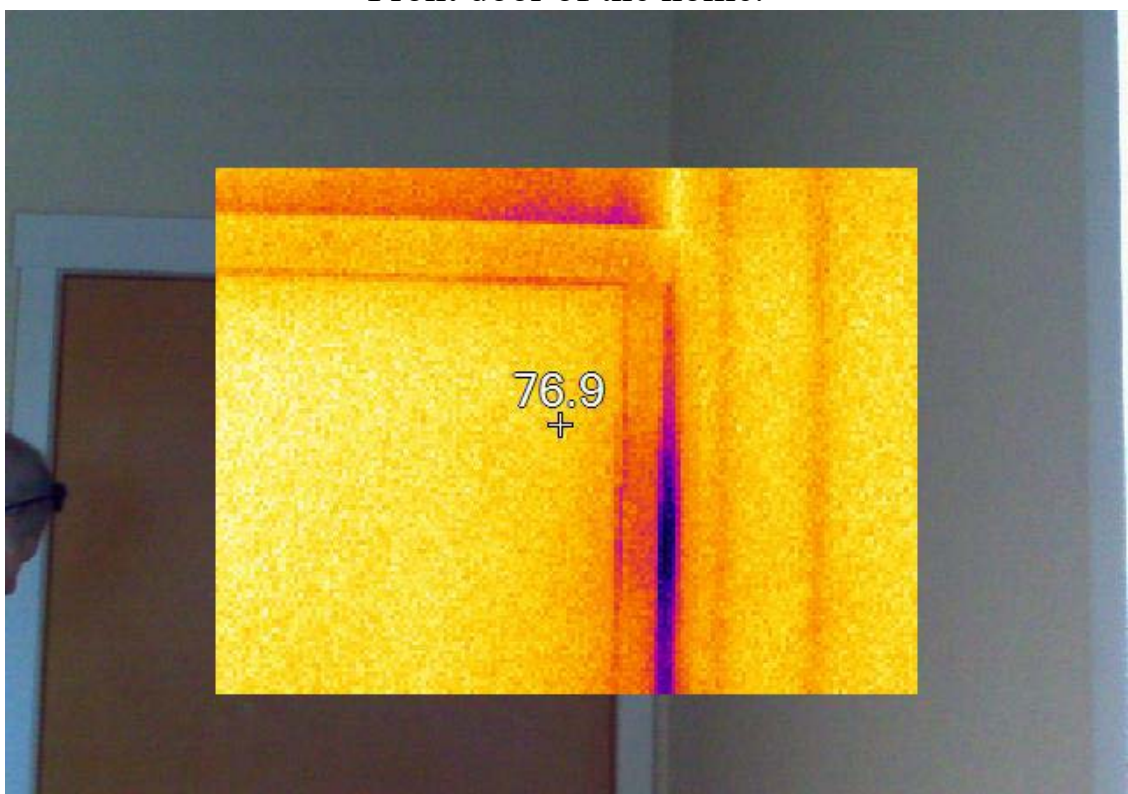

The infrared image shows substantial air leakage in dark red on top and around the trim. 


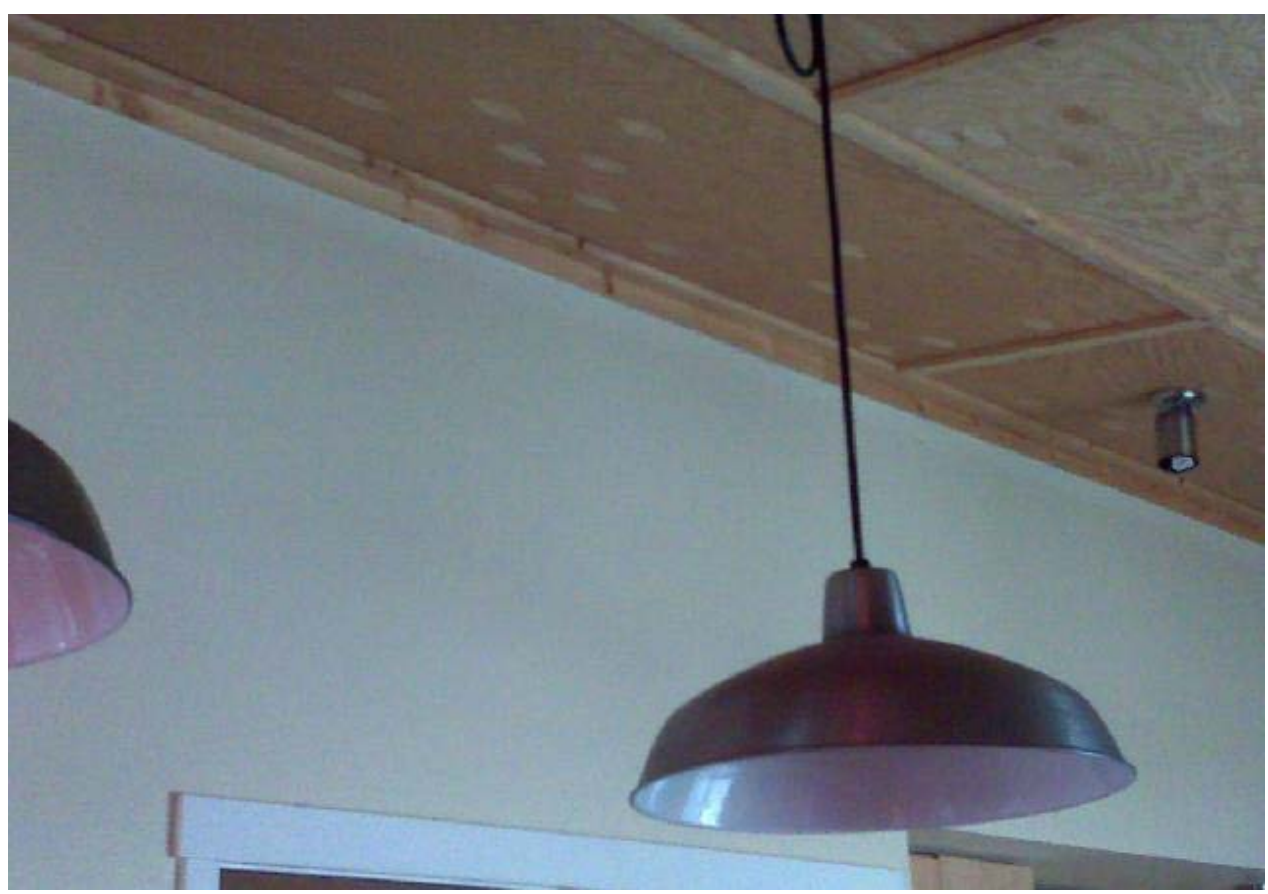

Ceiling in the living room/kitchen of the home.

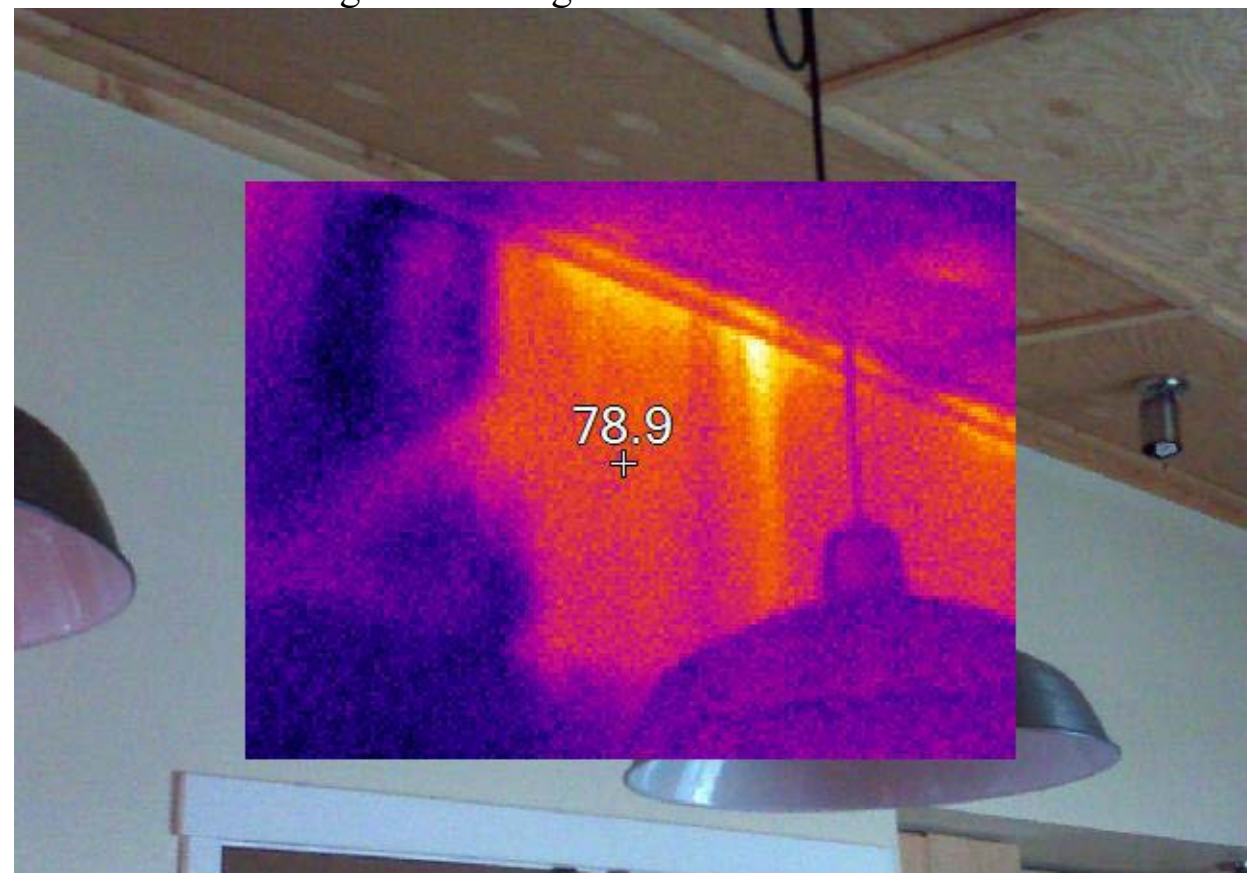

The yellow streaks represent air leakage from the attic. There were substantial leaks found along the perimeter where the wall meets the ceiling. The attic area is directly above the kitchen needs to be air sealed. This could be air sealed with clear caulking to improve occupant comfort. 


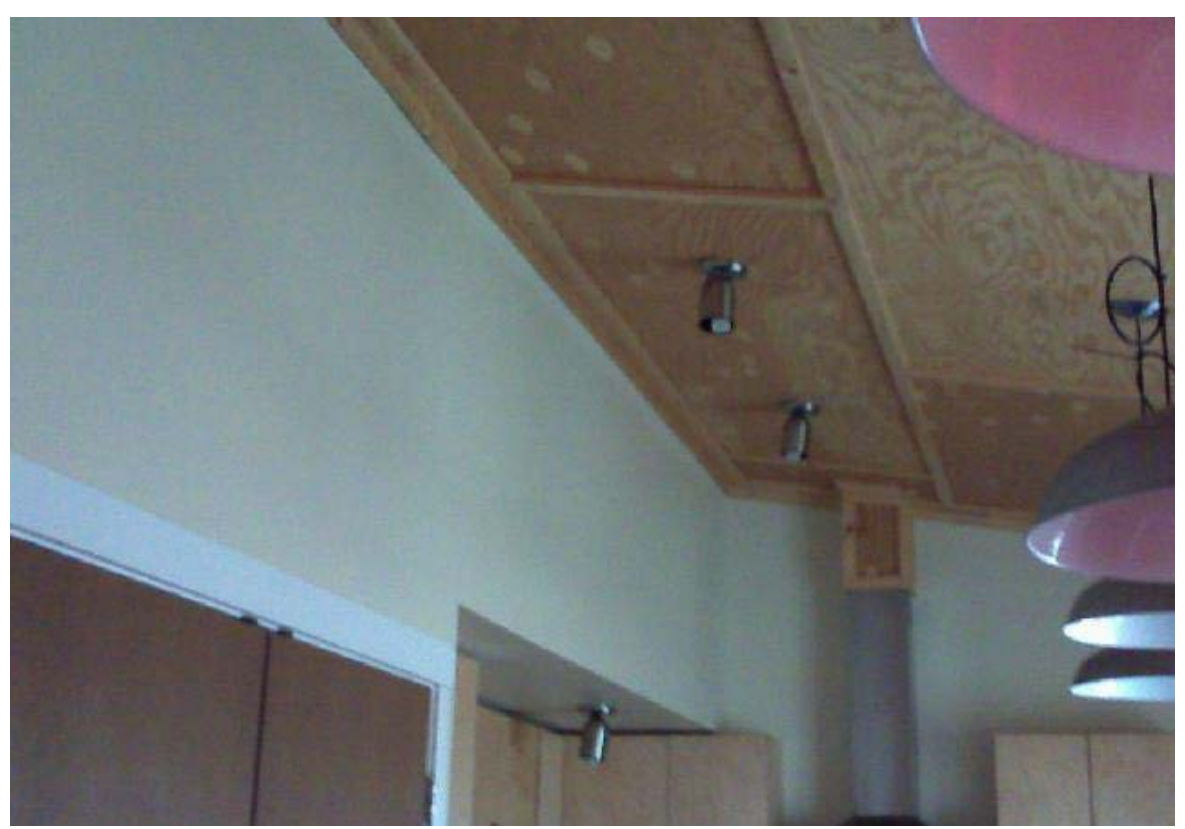

Ceiling in the living room/kitchen of the home.

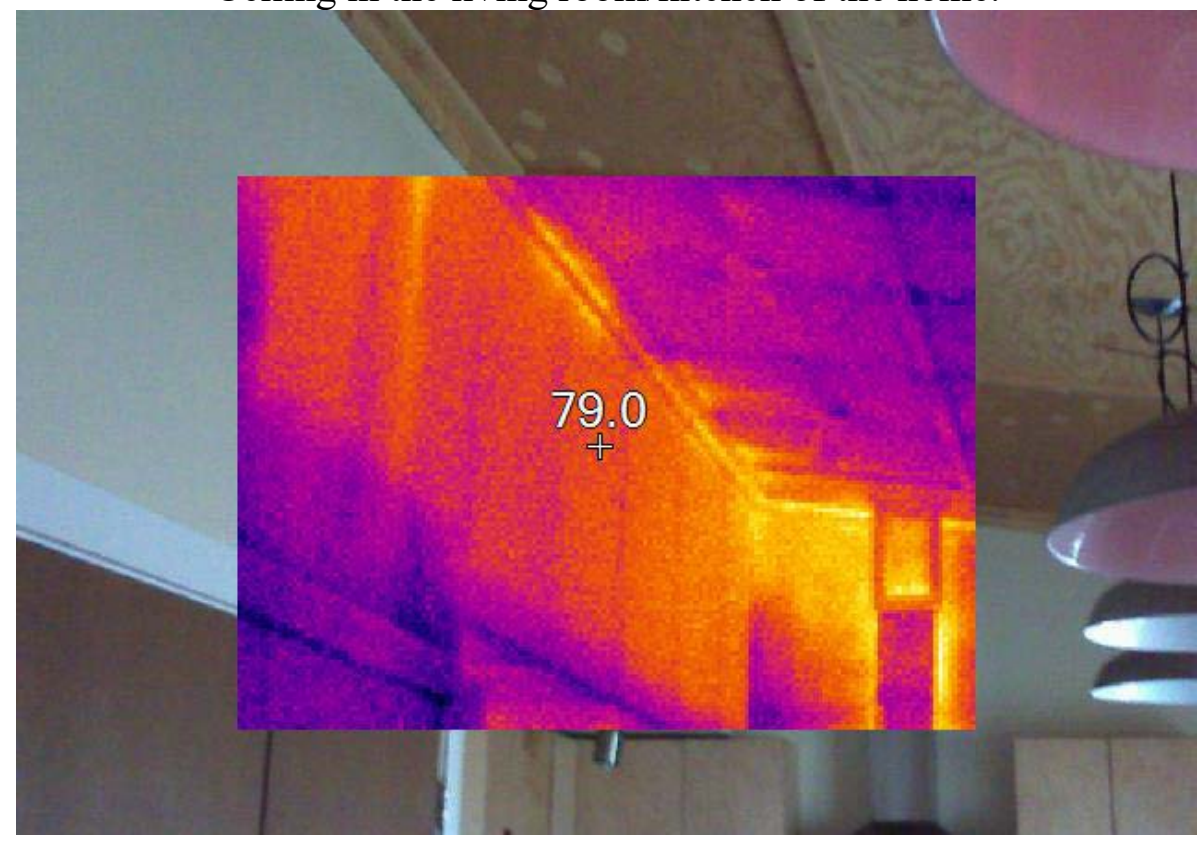

Additional air leakage in the kitchen. 


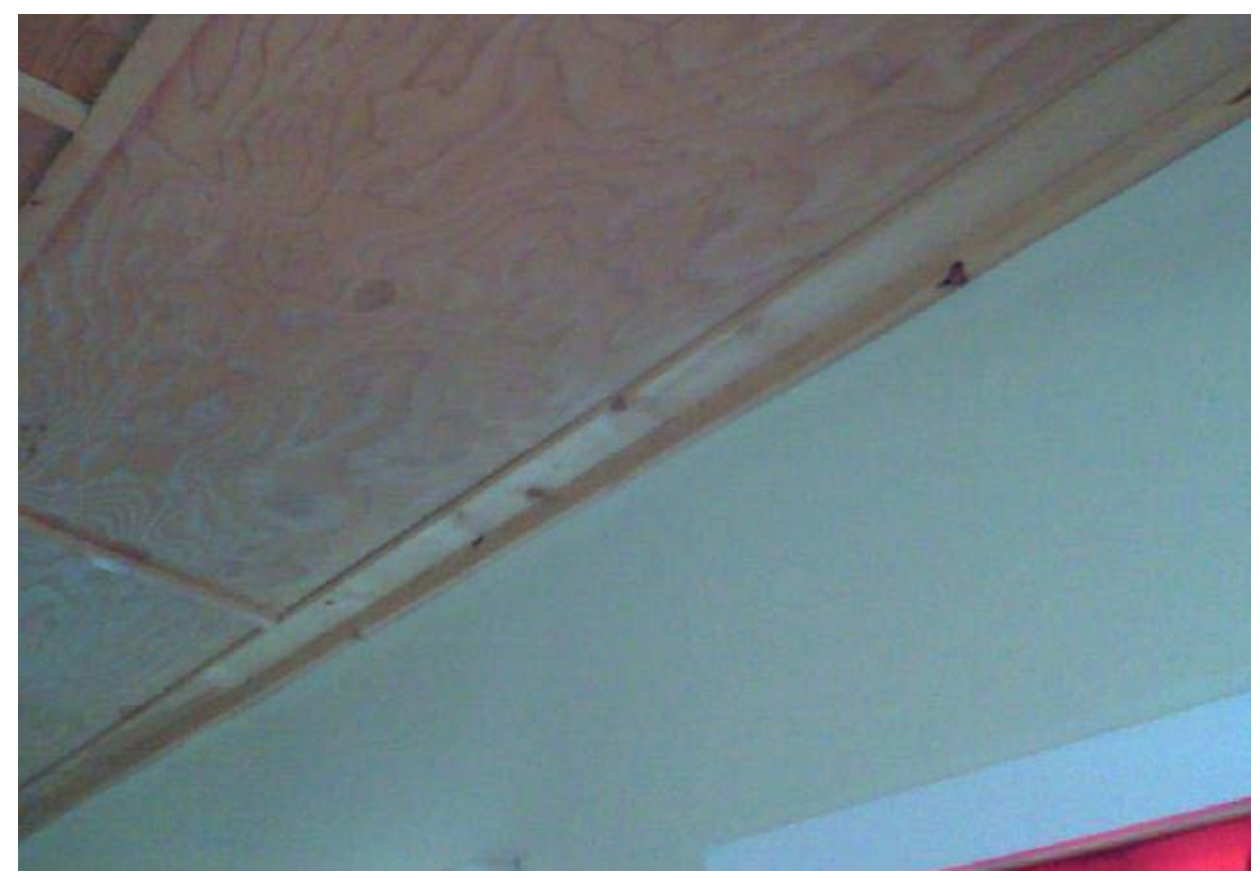

Ceiling in the living room/kitchen of the home.

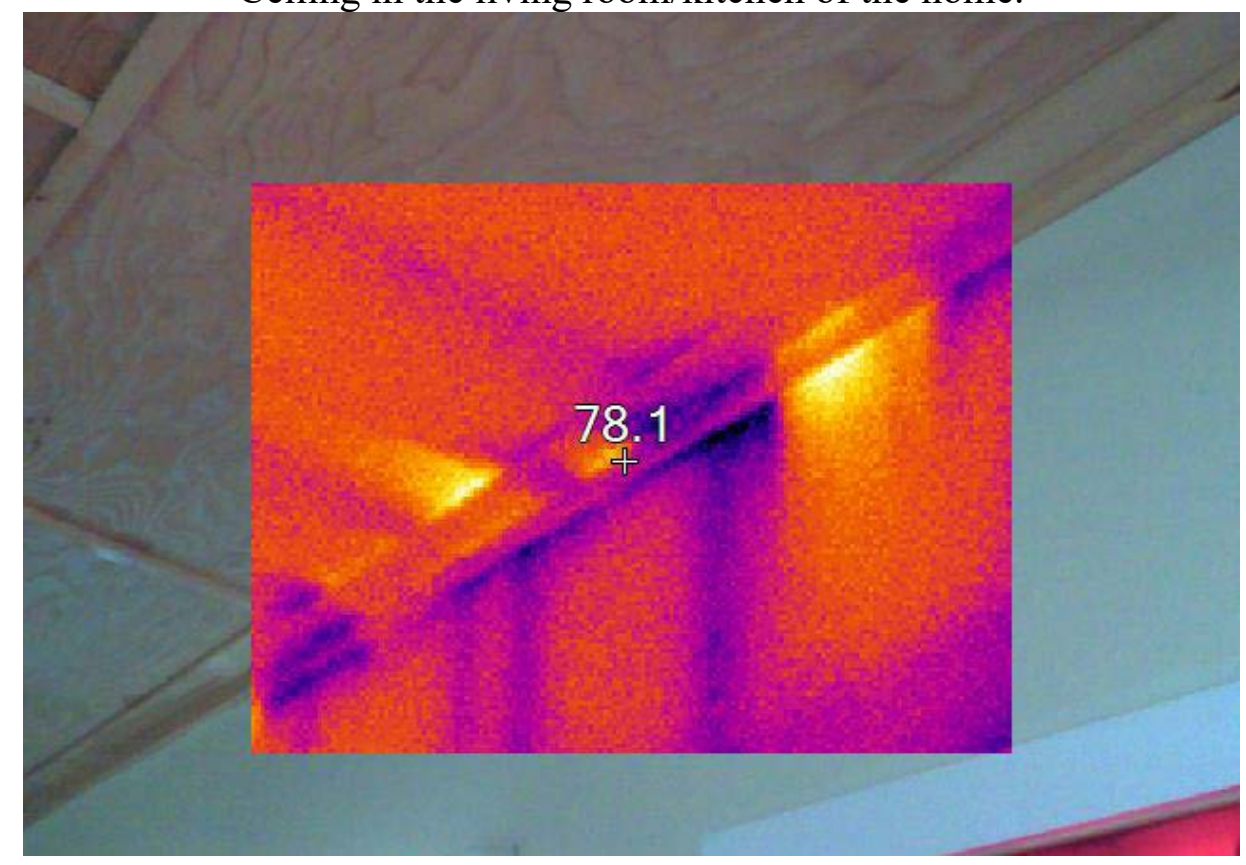

Additional air leakage in the living room of the home. 


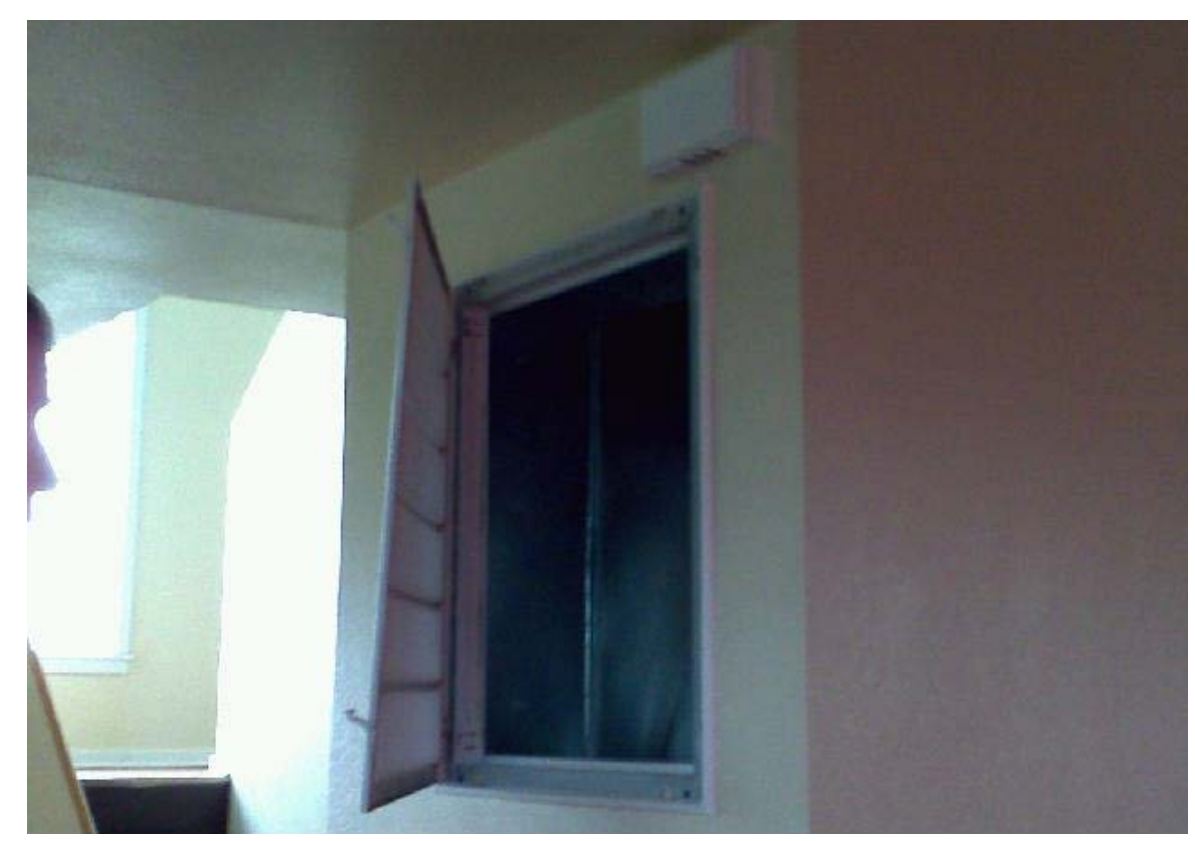

Return air duct in the home.

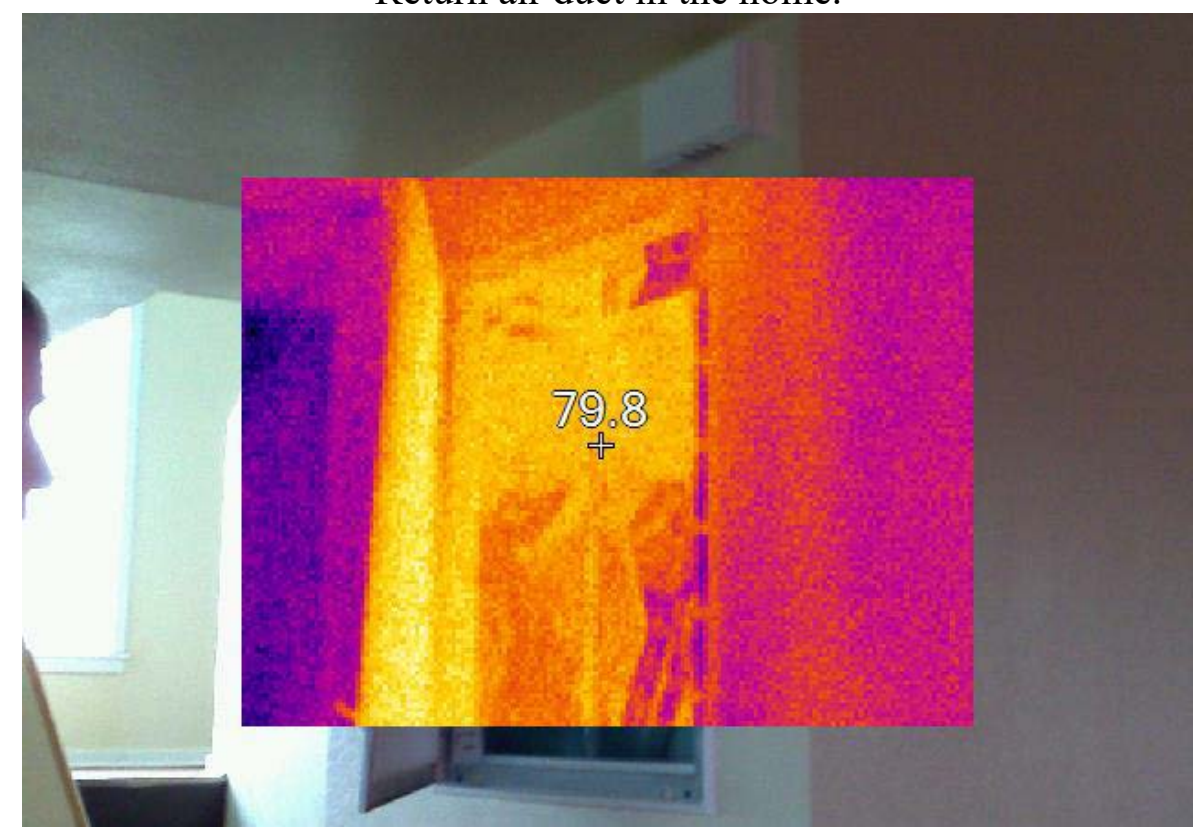

Due to the failure of the plastic air barrier in the return, cold unconditioned air comes directly into the living room, causing draftiness and resulting in substantial energy use. 


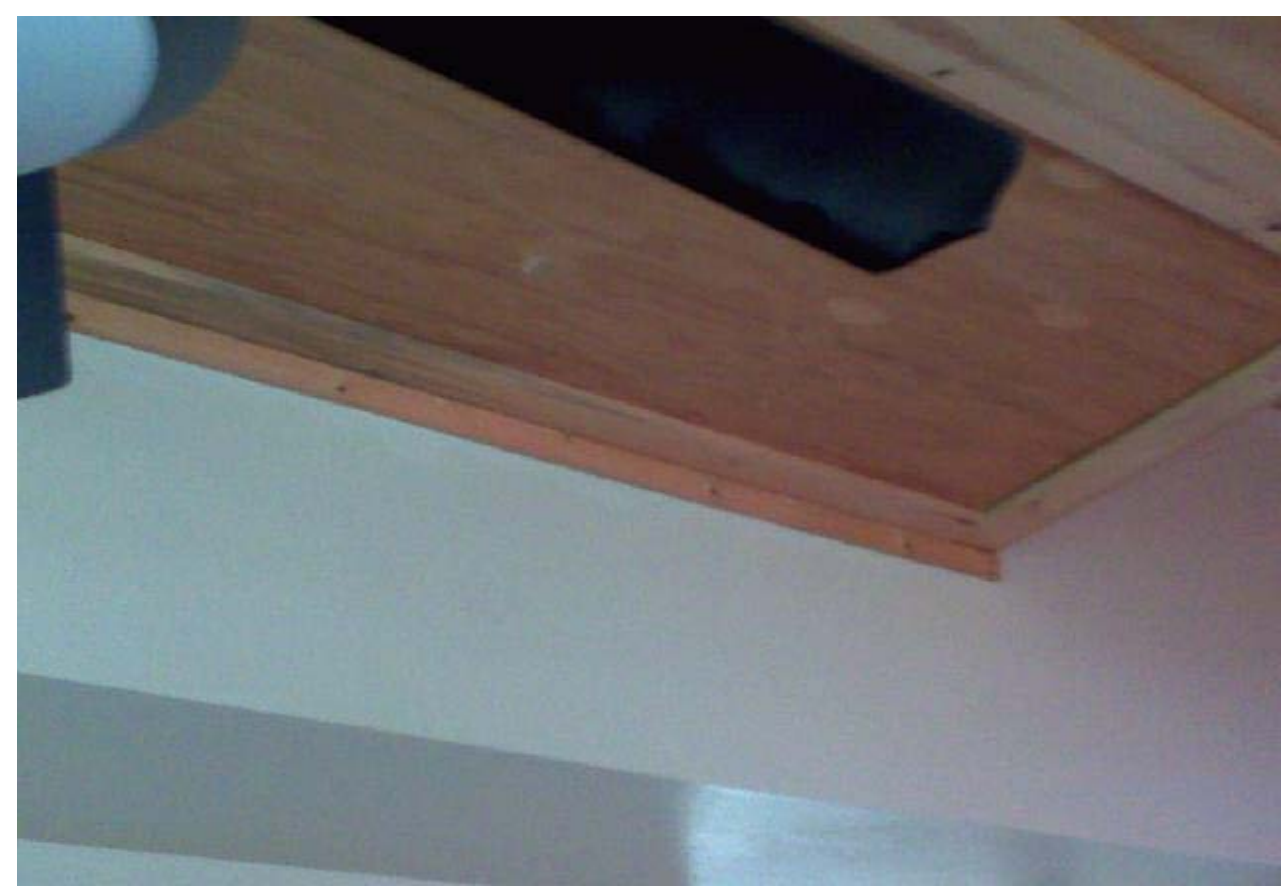

Ceiling in the living room.

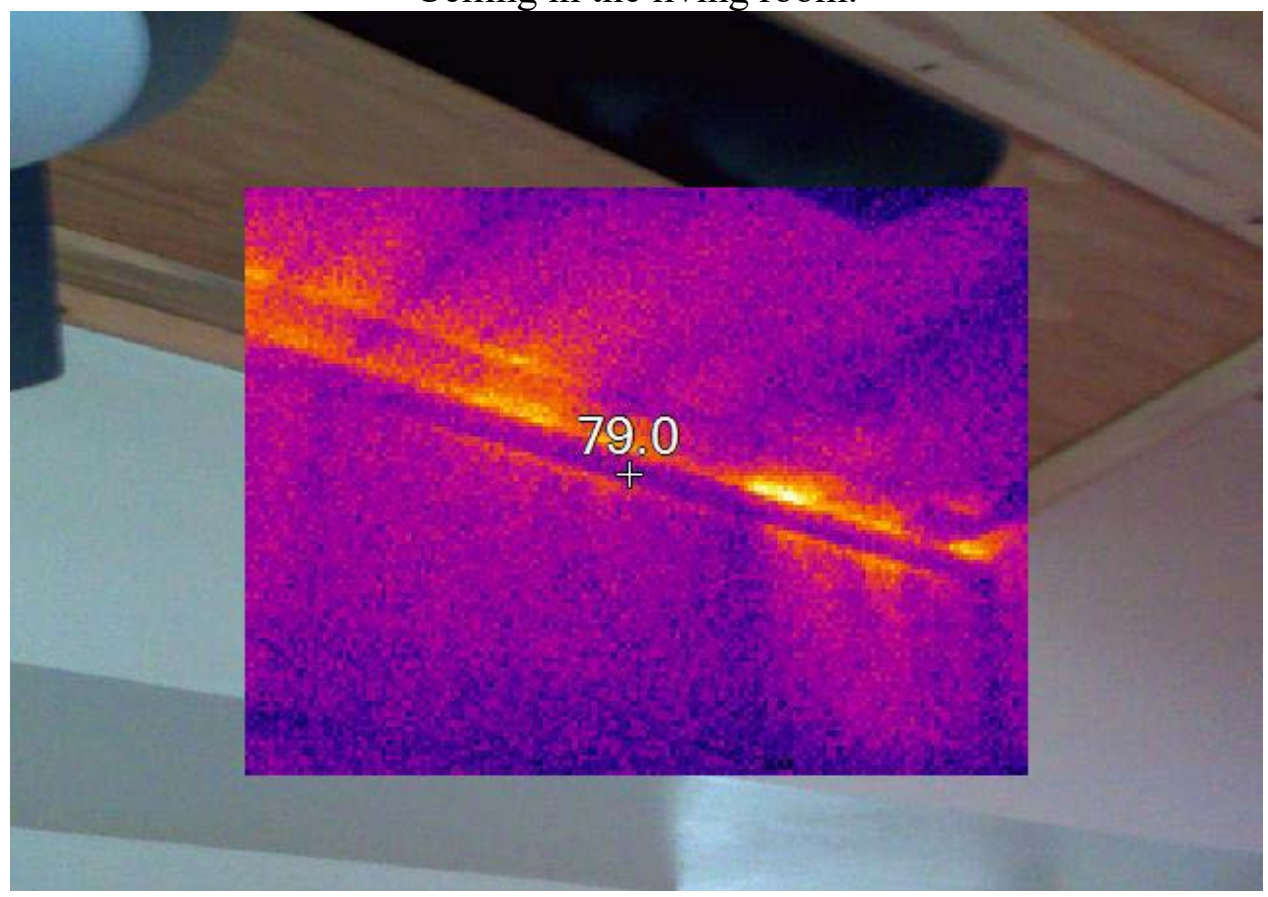

Additional air leakage in the living room. 


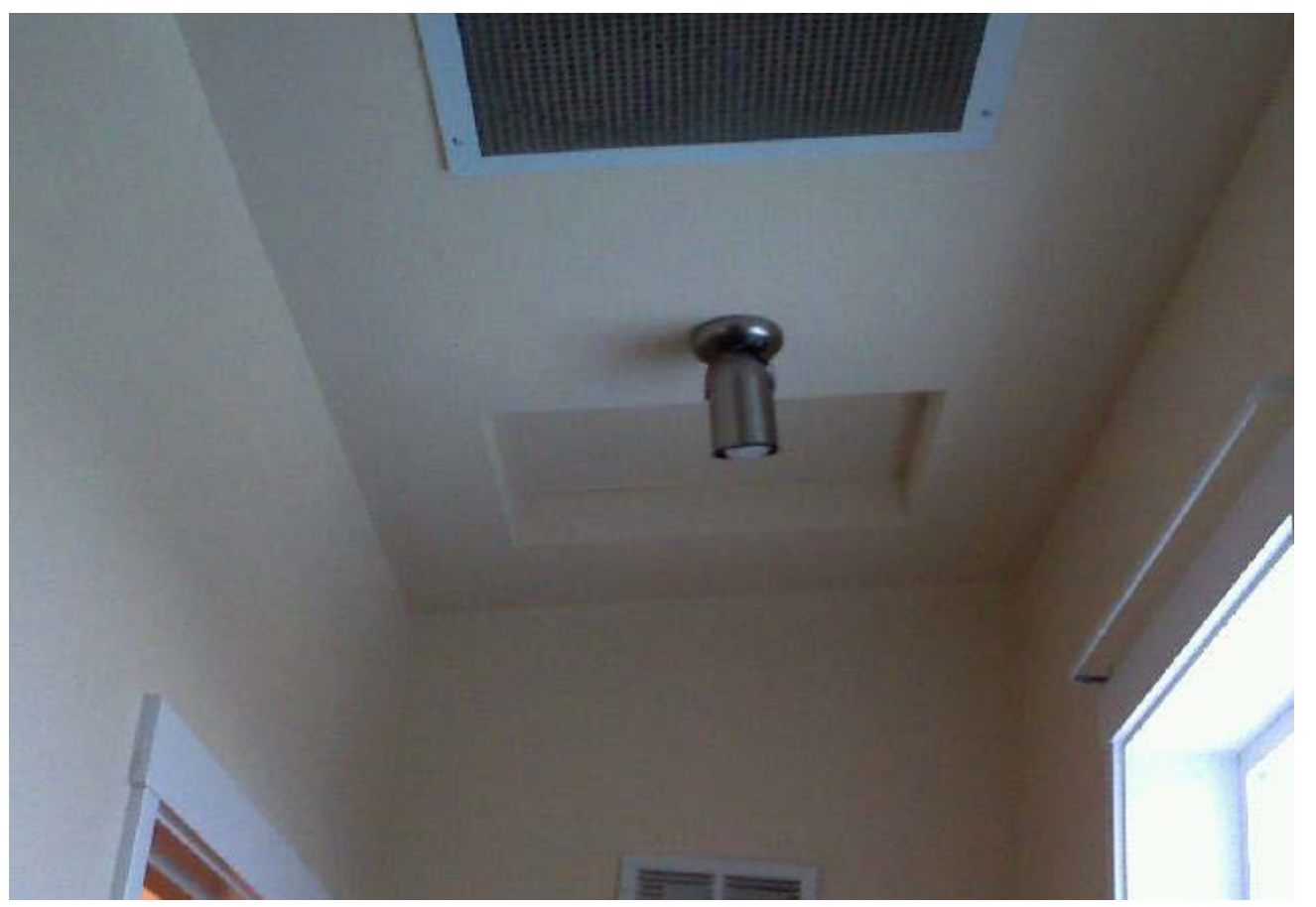

Upstairs attic hatch.

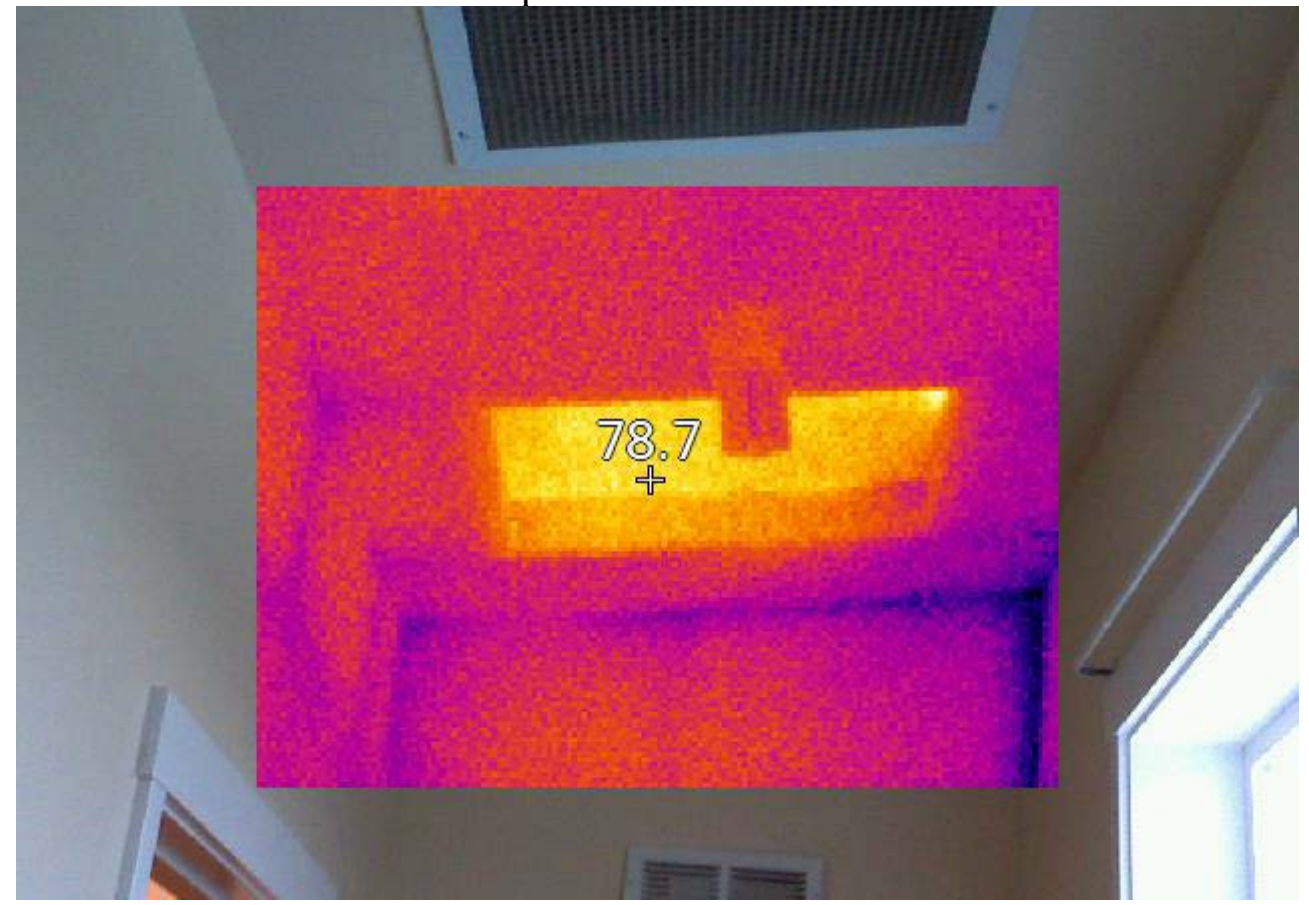

The temperature difference of the attic hatch indicates that there is no insulation in this part of the ceiling. 


\section{Energy Audit Report}

\section{$120 \mathrm{C}$ Street}

\section{Poplar MT}

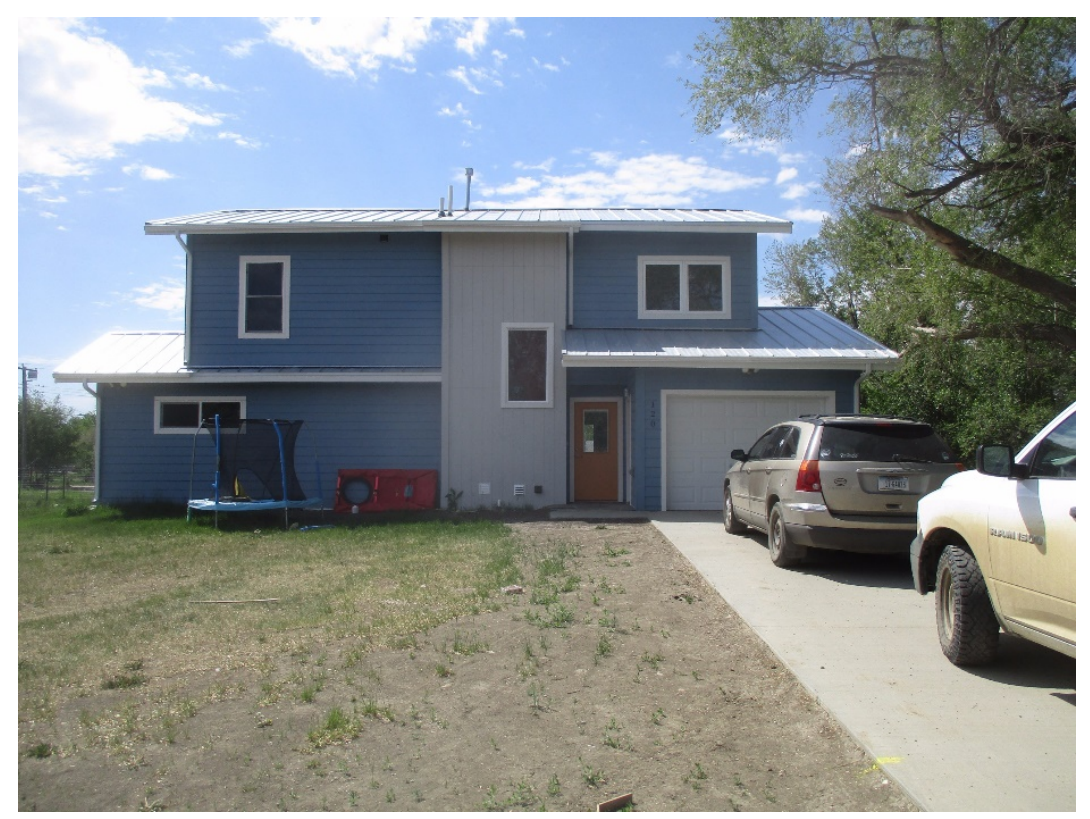

\section{Home Data}


Address

120 C Street

\begin{tabular}{lr} 
Year Built & 2012 \\
\hline Size & 1650 \\
\hline Direction & North \\
\hline Average Ceiling Height (ft) & 9 \\
\hline Blower Door & $3,500 \mathrm{CFM}$ \\
\hline Natural Air Changes & $\mathrm{NACH}=0.95$ \\
\hline
\end{tabular}

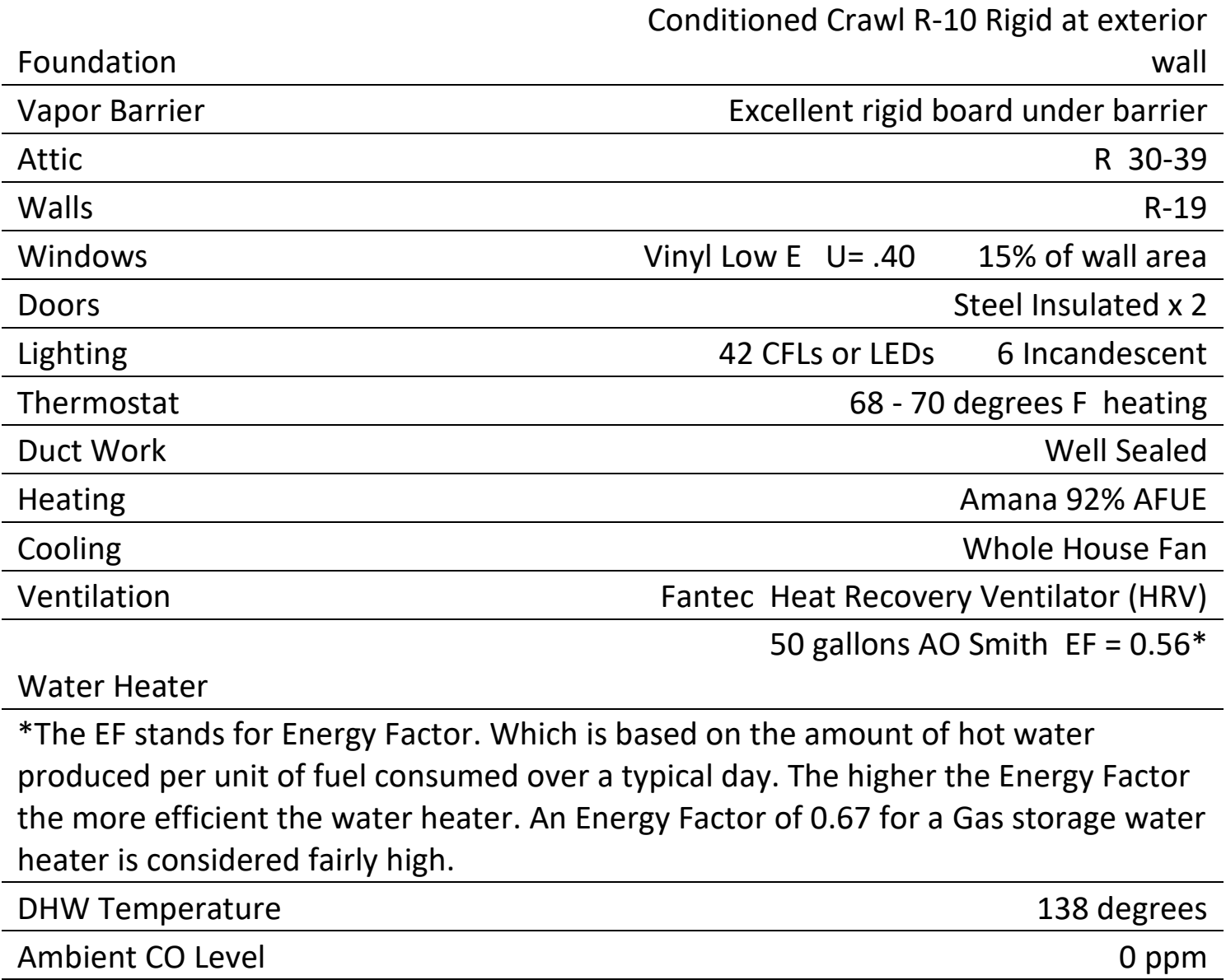

Domestic Hot Water (DHW) Carbon

Monoxide (air free) This is a standard

developed by Building Performance

Institute that measures the carbon

monoxide level in the flue. The maximum

level is 200 ppm

$11 \mathrm{ppm}$

Combustion Air

Yes for water heater

\begin{tabular}{lr}
\hline CO Alarms & Yes \\
\hline Safety Testing & Pass \\
\hline Appliances Energy Star & No \\
\hline
\end{tabular}




\section{General Housing Description:}

This home is a two story single family home, which was designed well for this climate zone. The home utilized a whole house fan for cooling in the summer forced air natural gas heating in the winter, And heat recovery ventilator for fresh air. The conditioned crawl space is purposely heated and contains a sump pump to remove water as the water table is close to the surface. This combination of building and ventilation methods works very well if the home is well sealed. During the energy audit, substantial leakage was found that is preventing the systems from working together effectively.

The team found quality workmanship on most aspects of the home, but found a couple of problems. The list of corrections is located in the Housing Inspection Notes section directly below.

\section{Housing Inspection Notes:}

1. Significant air leakage was detected in the ceiling of the kitchen/living room area.

2. The attic insulation was on the low side of what would be considered acceptable for this climate zone.

3. Air leakage in the home is high with a blower door reading of 3,500 CFM. This equates to an $\mathrm{ACH} 50$ of 14 or a NACH of .95. A tight home has an ACH50 of 3 and an NACH of .25. Since this home contains an HRV there is no lower limit for home tightness.

4. A home can benefit greatly from air sealing. Air sealing will keep the conditioned air that is heated or cooled from escaping to the outside as well as keeping unwanted outside air from getting into the home. Air sealing increases comfort and reduces energy use, which makes heating or cooling the home less expensive. Air sealing also reduces wear and tear on the heating and cooling systems by reducing the amount of work the systems have to do to keep the home comfortable. This home has an air exchange rate of $108 \%$ every hour. The home can be safely air sealed to an air exchange rate of $25 \%$ - 35\% every hour without installing mechanical ventilation. This home has mechanical ventilation and therefore has no lower limit for air sealing. The latest studies have proven that air tight homes with mechanical ventilation are more effective at increasing the overall health and lifespan of the average person. Mechanical ventilation is preferable to natural ventilation because natural ventilation does not filter or control the source of air that is entering the home. This air can come from attics, basements, and crawlspaces, which may contain a variety of harmful pollutants. Mechanical ventilation brings air into the home from directly outside and can be fitted with filtration systems to increase the purity of the outside air entering the home. The benefits of controlled ventilation far outweigh the small electrical use to operate the system.

5. A conditioned unvented crawl space with a sump pump to remove water works well in this climate zone.

6. Water only has to be between 120 and 125 degrees for sanitation purposes. Lowering your water temperature makes it easier for the water heater to maintain its temperature and uses less natural gas while reducing standby losses. Simply measure the water temperature with a cooking thermometer and adjust the water heater temperature control until you reach 120 degrees. 


\section{Recommendations:}

\begin{tabular}{|c|l|}
\hline Recommendations: & Cost \\
\hline $\begin{array}{l}\text { 8. } \\
\begin{array}{l}\text { Remove or relocate insulation in } \\
\text { the kitchen living room area of the } \\
\text { home and air seal the ceiling. Use } \\
\text { a blower door after air sealing to } \\
\text { verify reduction of air leakage. }\end{array}\end{array}$ & $\$ 1,000$ all labor \\
\hline 9. Add ceiling insulation to R-49 - R-60 & $\$ 800$ \\
\hline 10. Insulate the attic hatch & $\$ 50$ \\
\hline 11. Clean HRV filter on a regular basis & 1 hour labor \\
\hline $\begin{array}{l}\text { 12. Lower hot water temperature from } \\
138^{\circ} \mathrm{F} \text { to } 120^{\circ} \mathrm{F}\end{array}$ & $\$ 0$ \\
\hline
\end{tabular}

\section{Safety:}

No safety issues were observed.

\section{Conclusion:}

Overall, the home seemed to be well designed. For future construction, the team would recommend testing of the home tightness (blower door) before final construction sign off. The home should achieve a reading of 3 air changes per hour. (ACH50). For a 1,500 square foot home with an average of a 9 foot ceiling the blower door reading should be no greater than 675 $\mathrm{cfm}$. The math formula to calculate the number of air changes per hour from a blower door test is as follows:

Air Changes per Hour $(A C H)=\frac{\text { Cubic Feet Per Minute }(C F M)}{\text { Cubic Volume of Home }} \times \frac{60 \text { minutes }}{\text { hour }}$

With this level of house tightness mechanical ventilation by the installation an HRV is necessary to maintain a healthy indoor air quality.

The team would recommend closed combustion on the water heater. The team would recommend increasing insulation values in the homes from 38 to 49 in the ceiling, R-19 to R-21 in the walls, and designing as close to passive house standards. The Cold Climate Housing Research Center. (http://www.cchrc.org/publications) has publications that include design best practices and good ideas for efficient design. The team would recommend more occupant education on operation of the whole house fan. 
The IECC 2015 prescriptive measures for the building shell in climate zone 7 are as follows:

TABLE R402.1.2

INSULATION AND FENESTRATION REQUIREMENTS BY COMPONENT ${ }^{\sharp}$

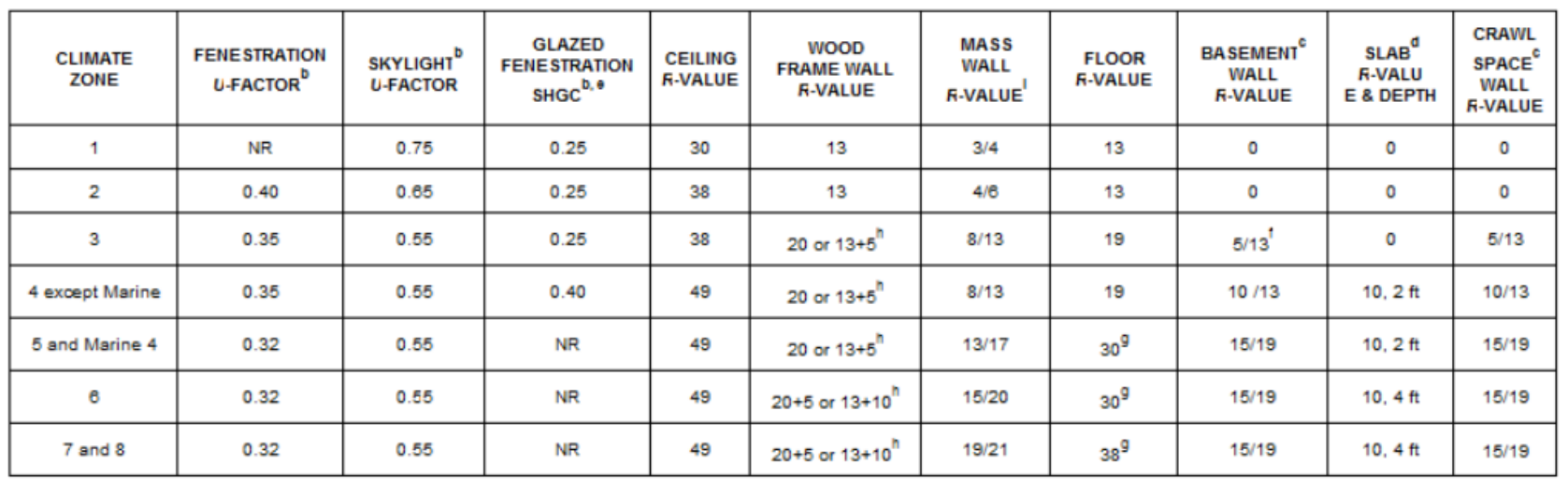




\section{Site Visit Pictures}

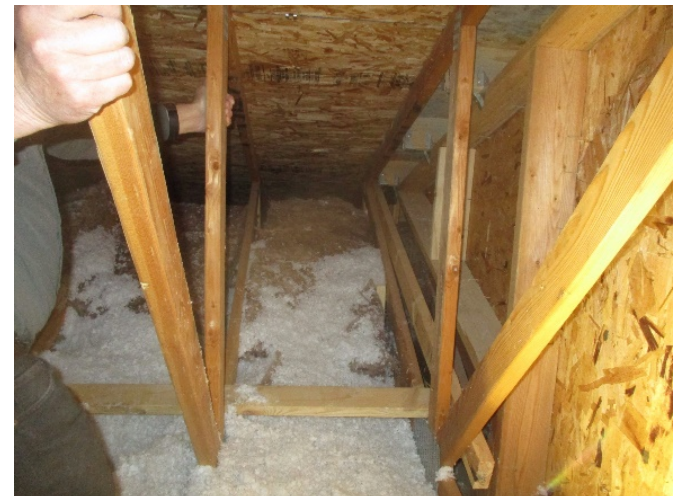

Attic Insulation poorly aligned batt/ garage access

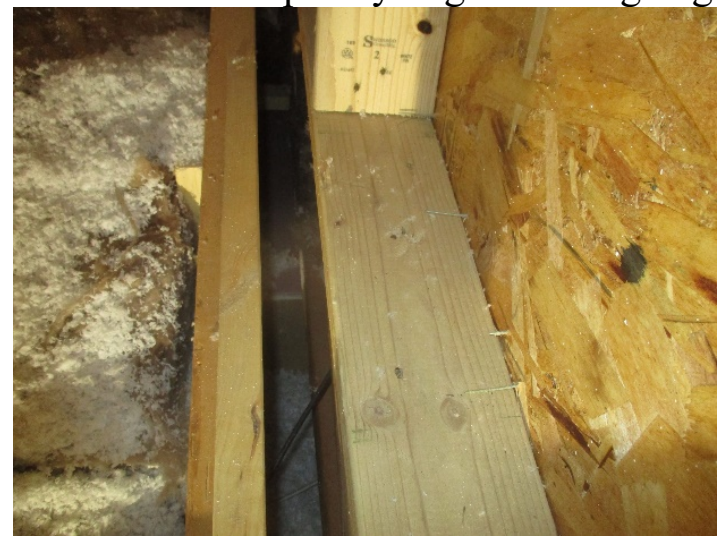

Air gap in the garage attic area

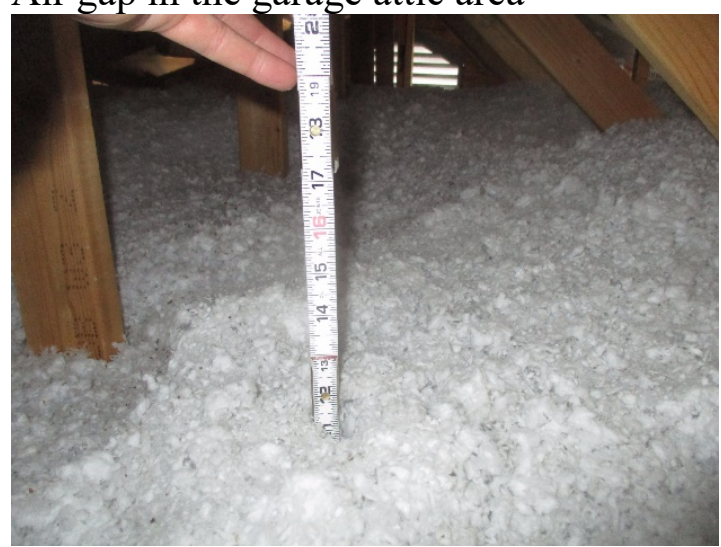

Depth of attic insulation 10"

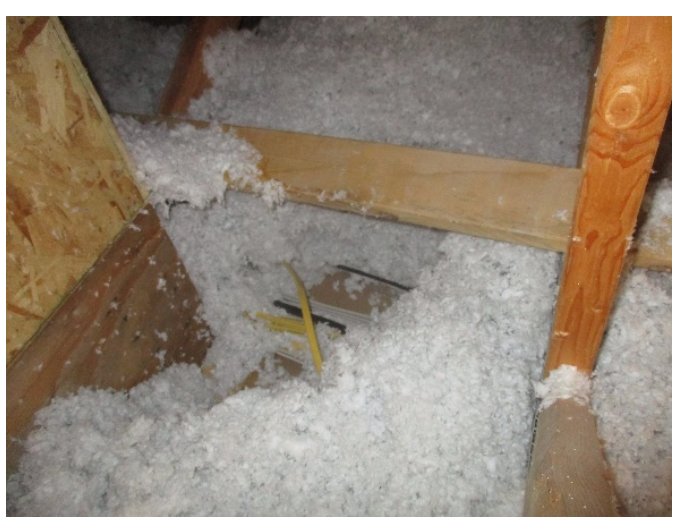

Missing attic insulation garage access
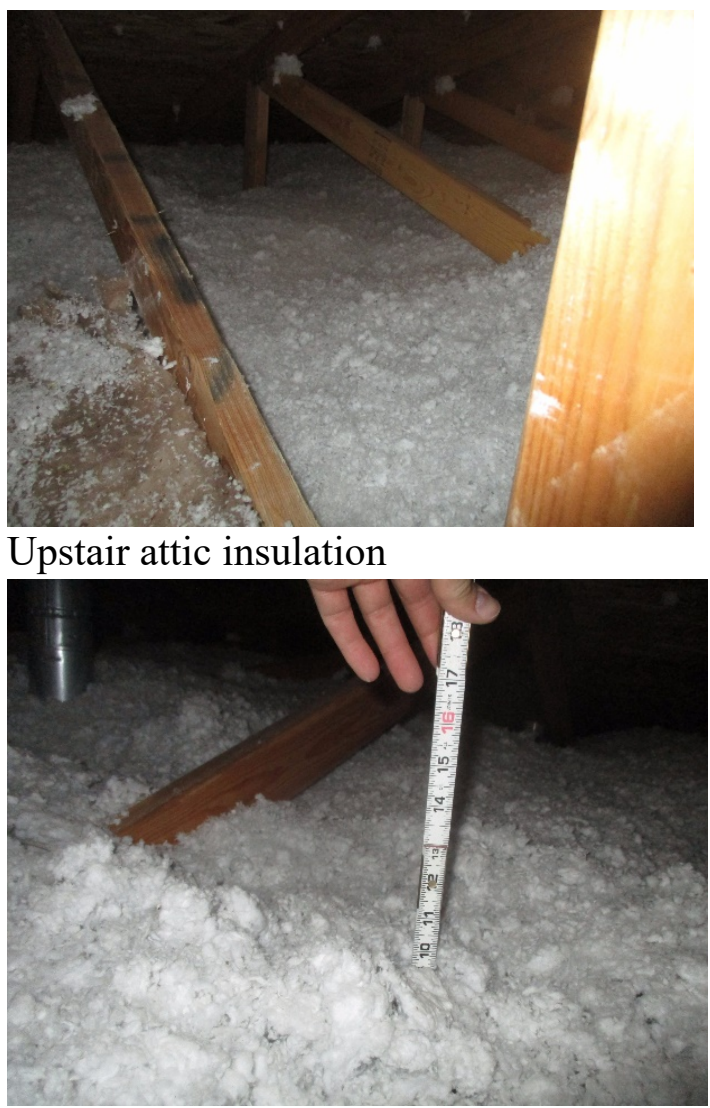

Top attic picture 


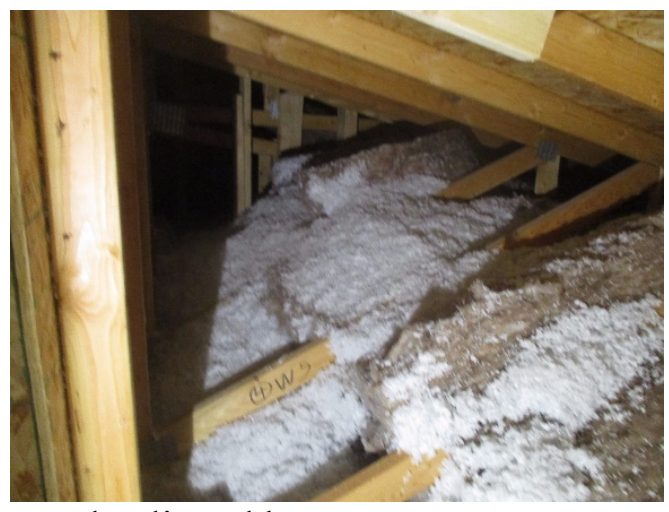

Poorly aligned batts

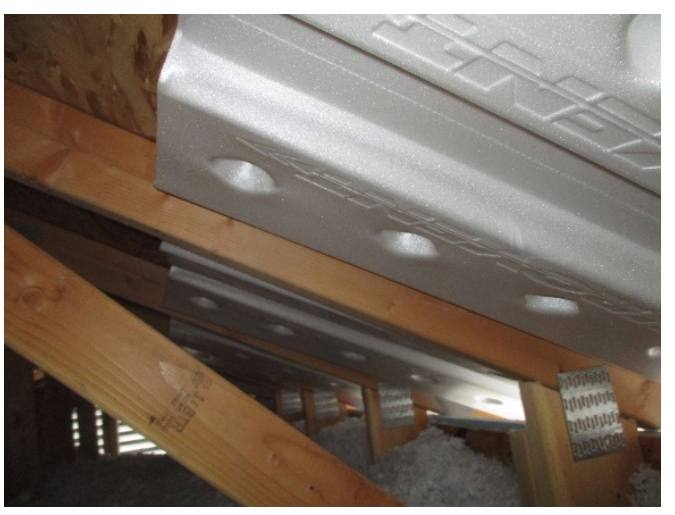

Soffit baffels - additional insulation can be added 


\section{Infrared Photos}

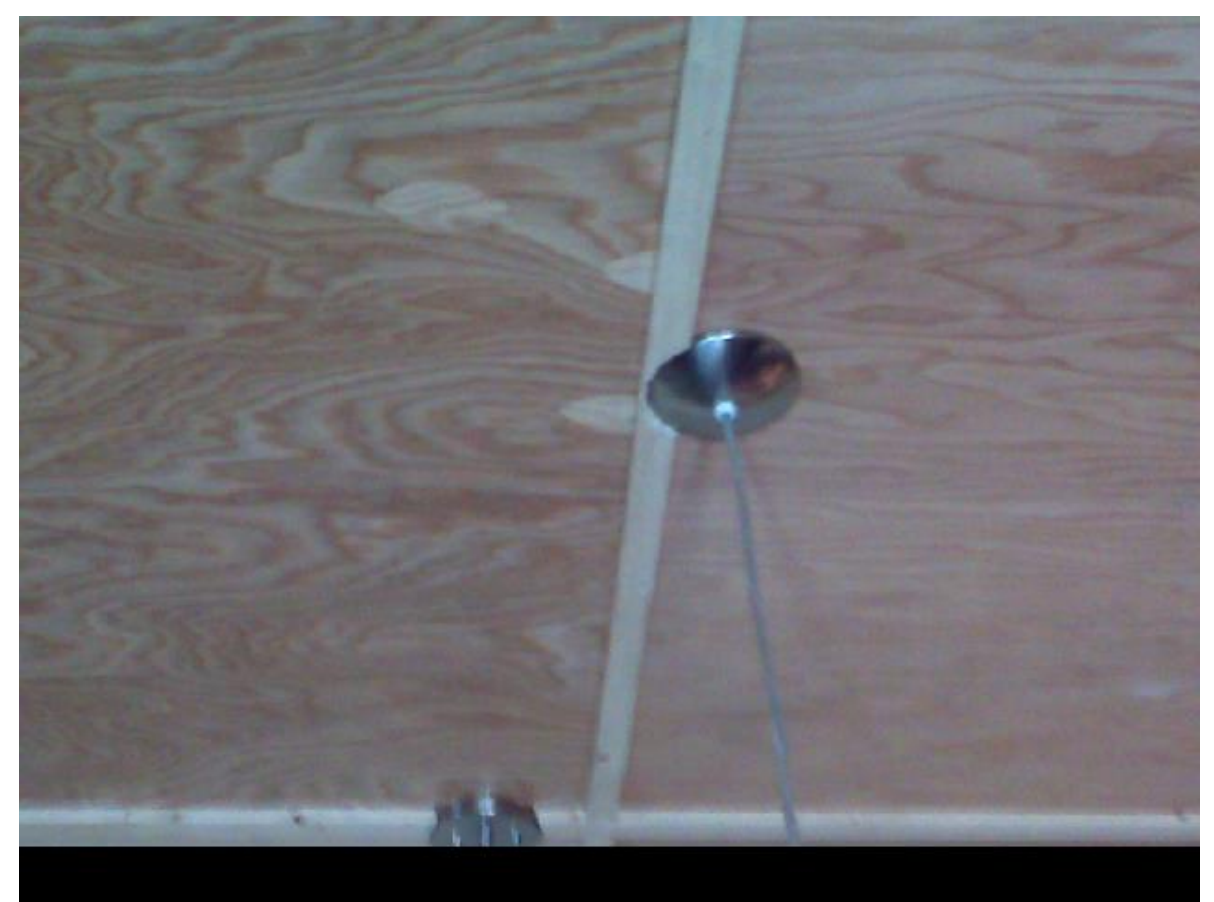

Batten covering the seams in the ceiling panel.

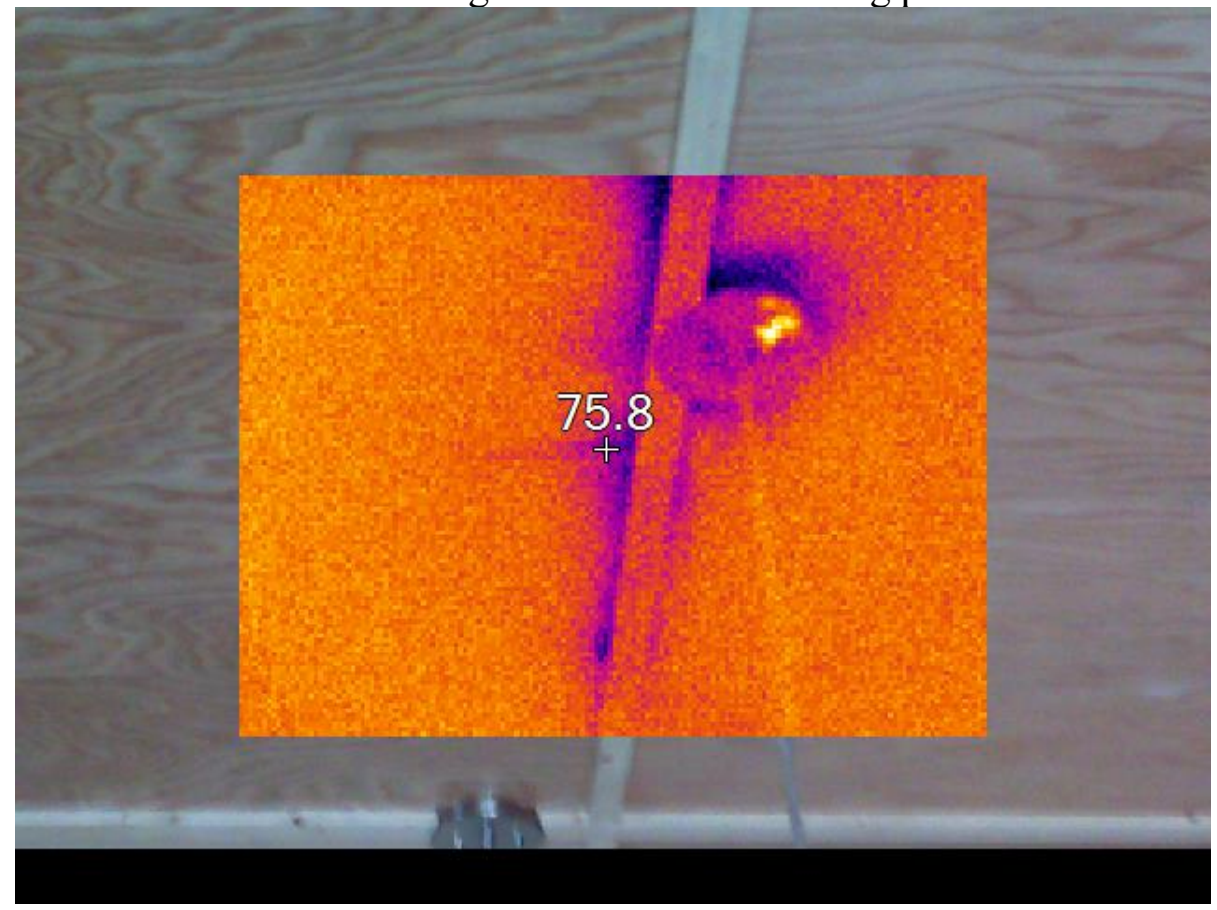

Dark blue represents air leakage.

Appendix B: Energy Audit Data

Ceiling edge in the living room. 


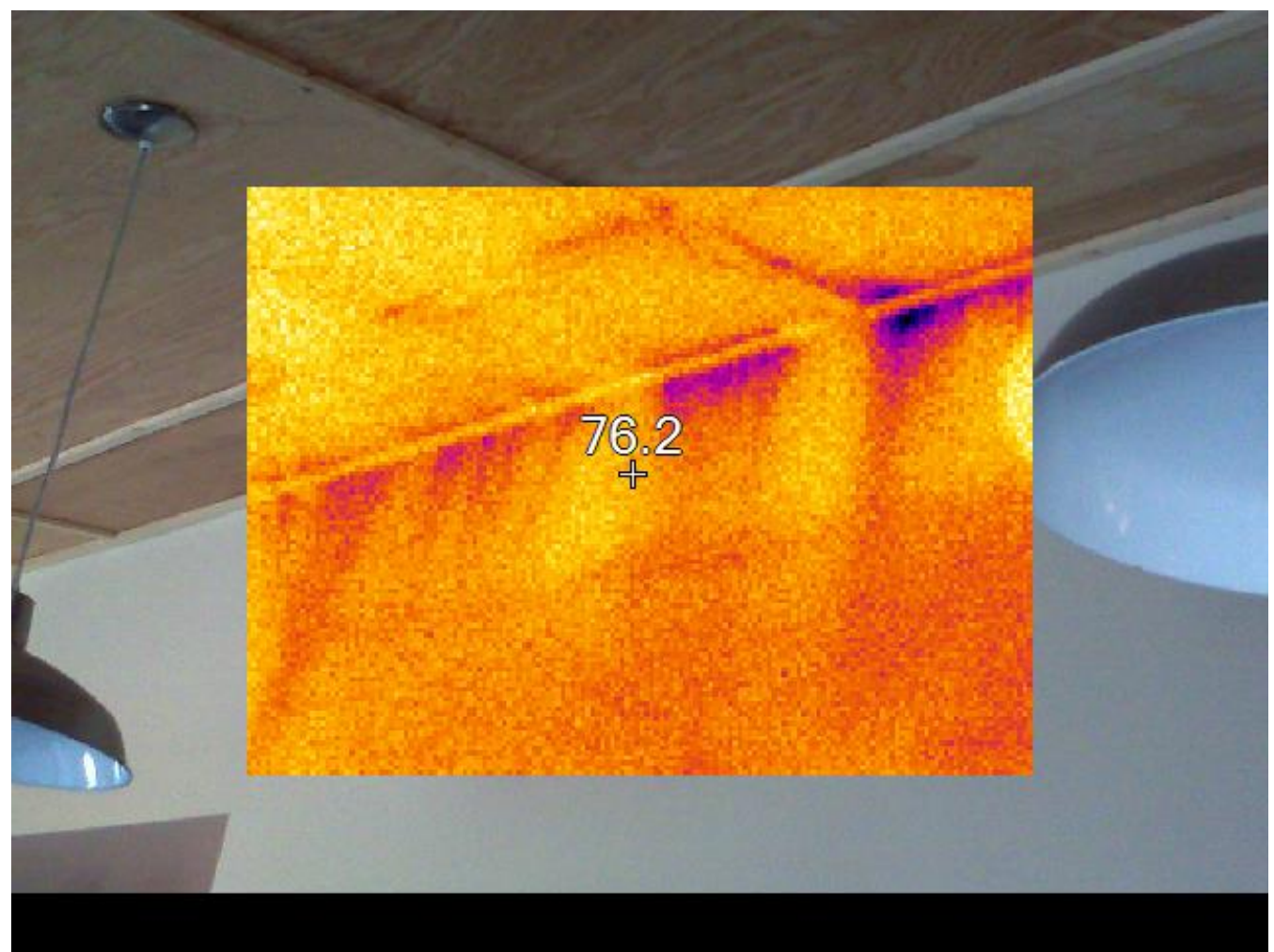

Red streaking represents air leakage.

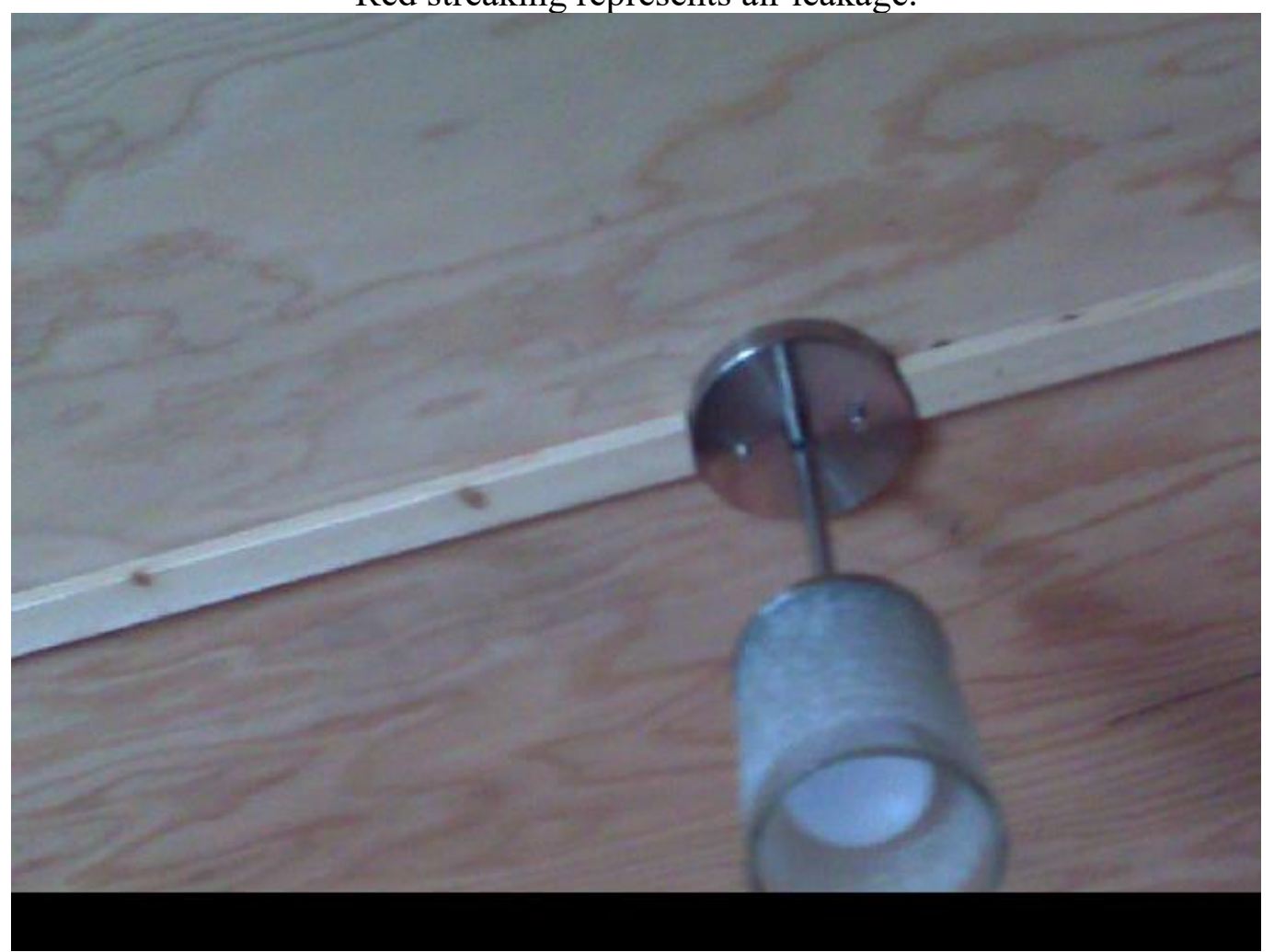

Light fixture in the wooden ceiling. 


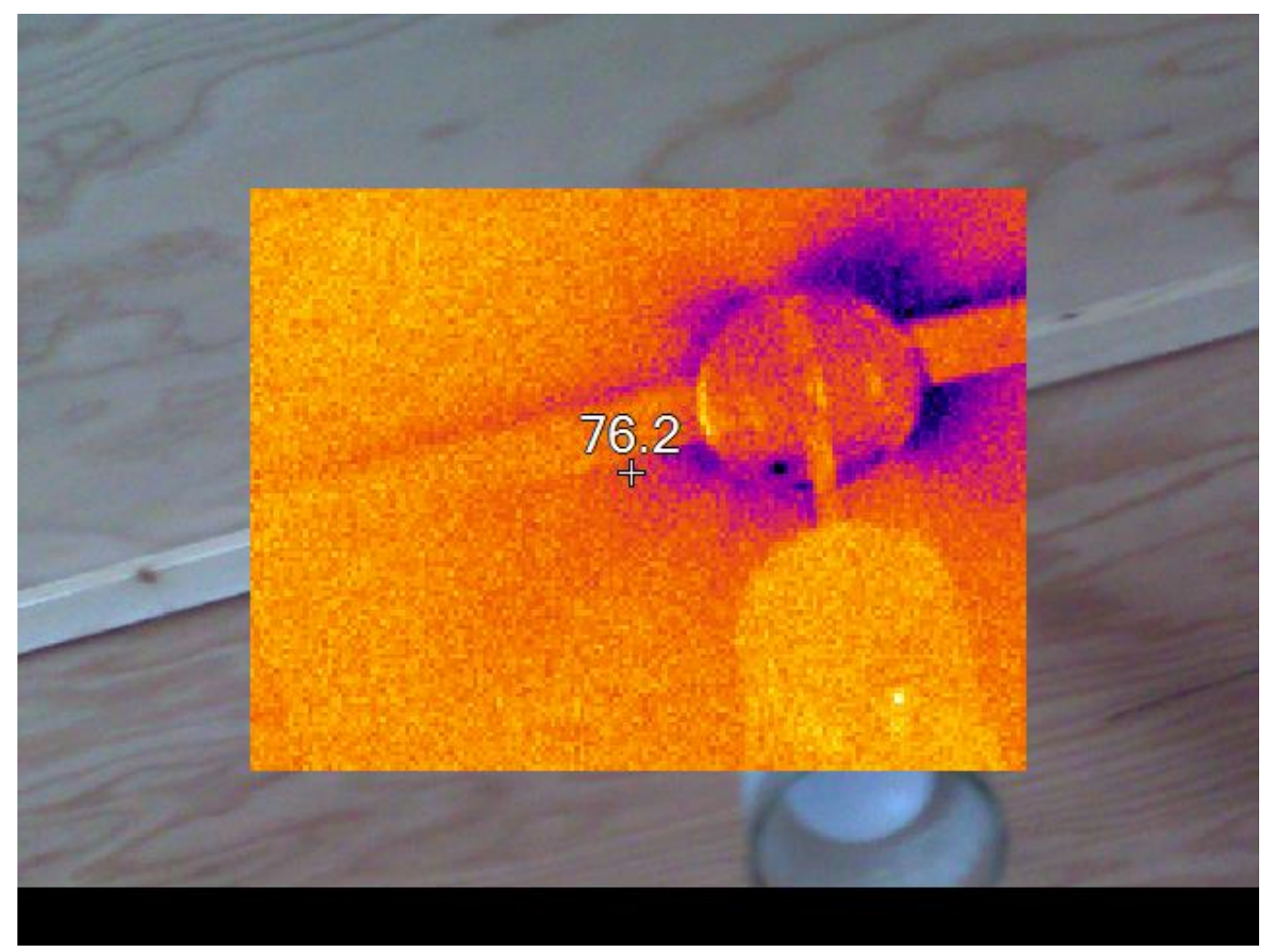

The blue areas represent air leakage through the ceiling.

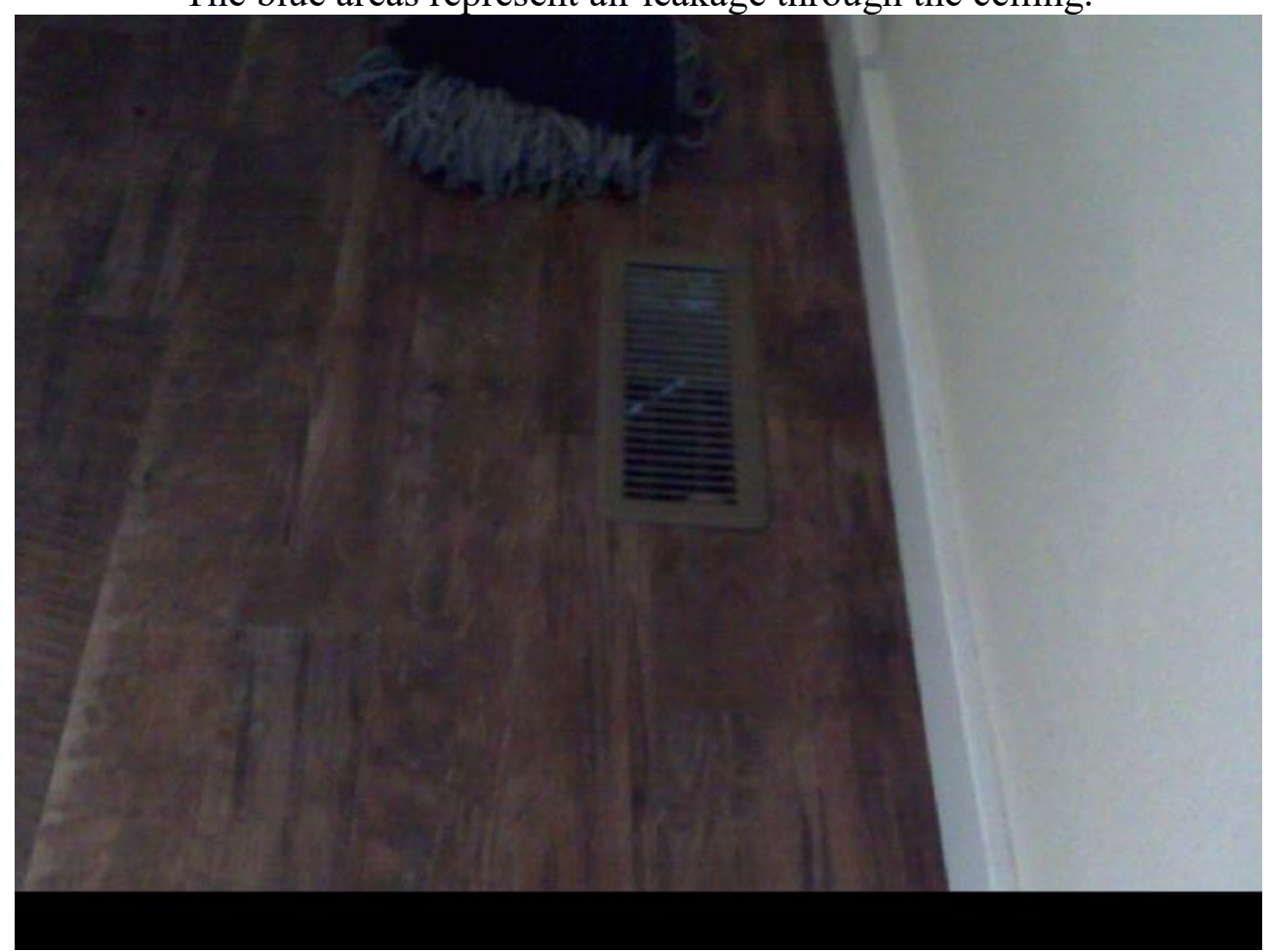

Air leakage through the floor vent. 


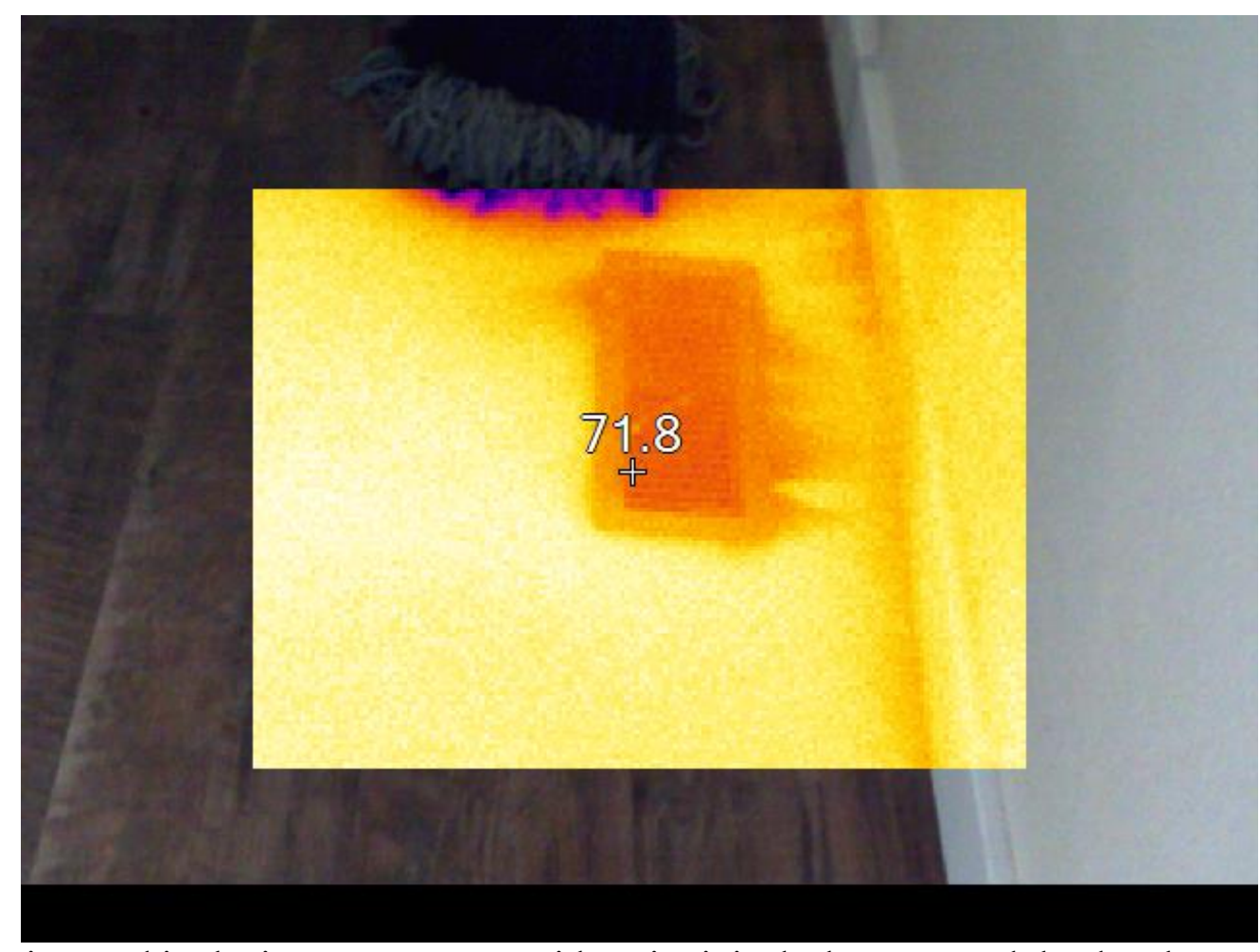

The wispy red in the image represents either rim joist leakage around the duct boot or duct leakage.

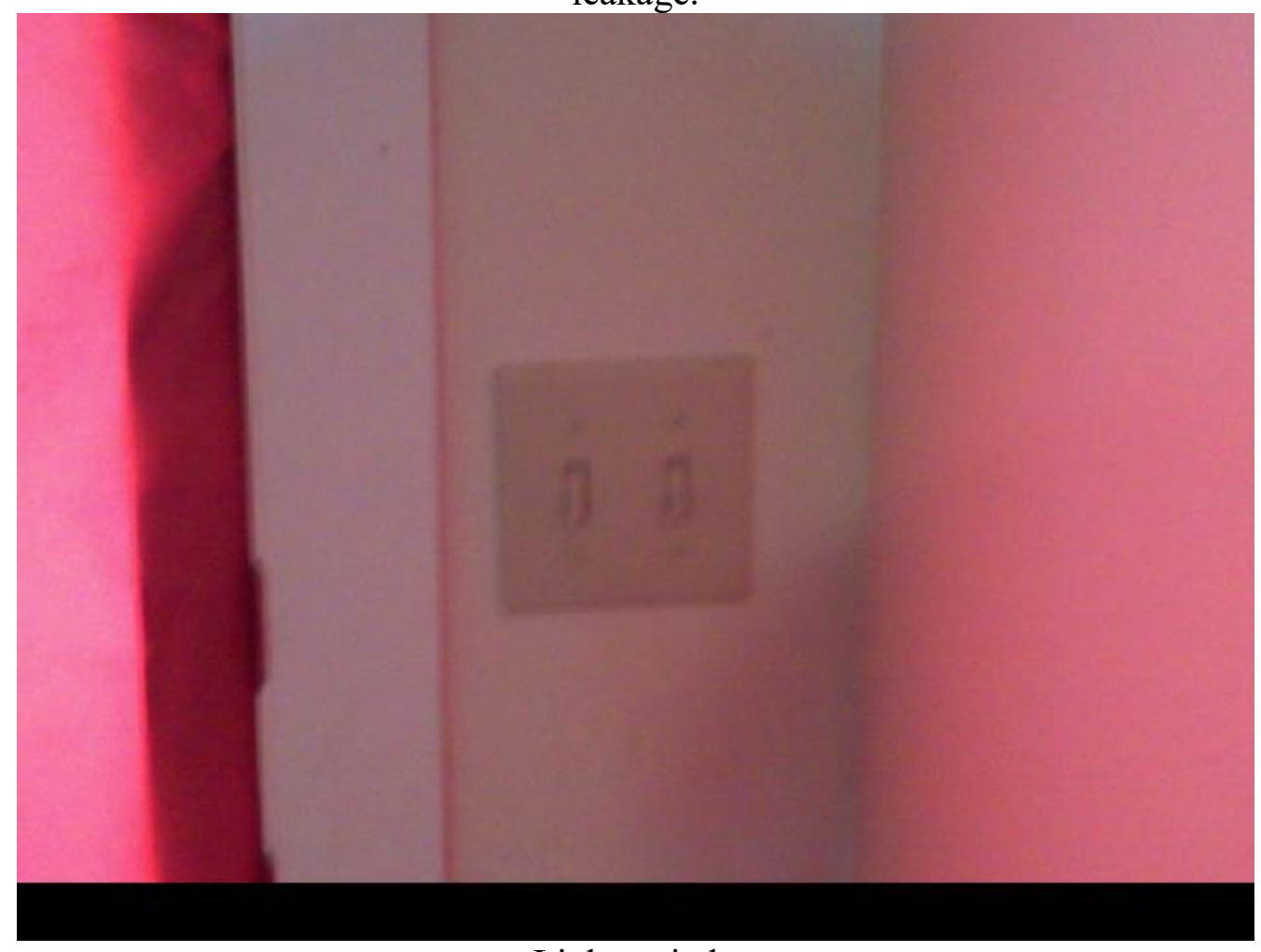

Light switch. 


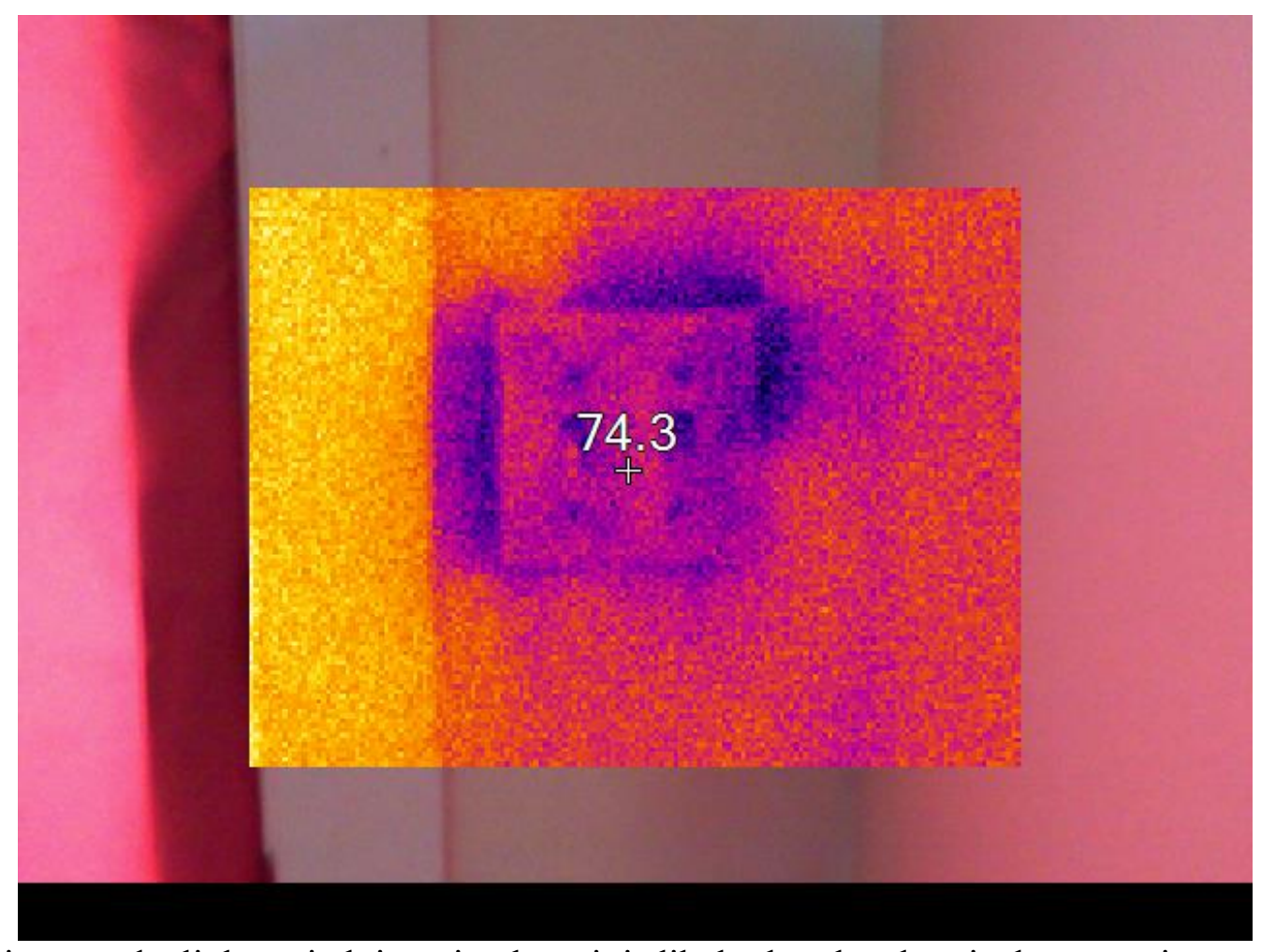

Cold air around a light switch junction box, it is likely that the electrical penetrations were not sealed during construction.

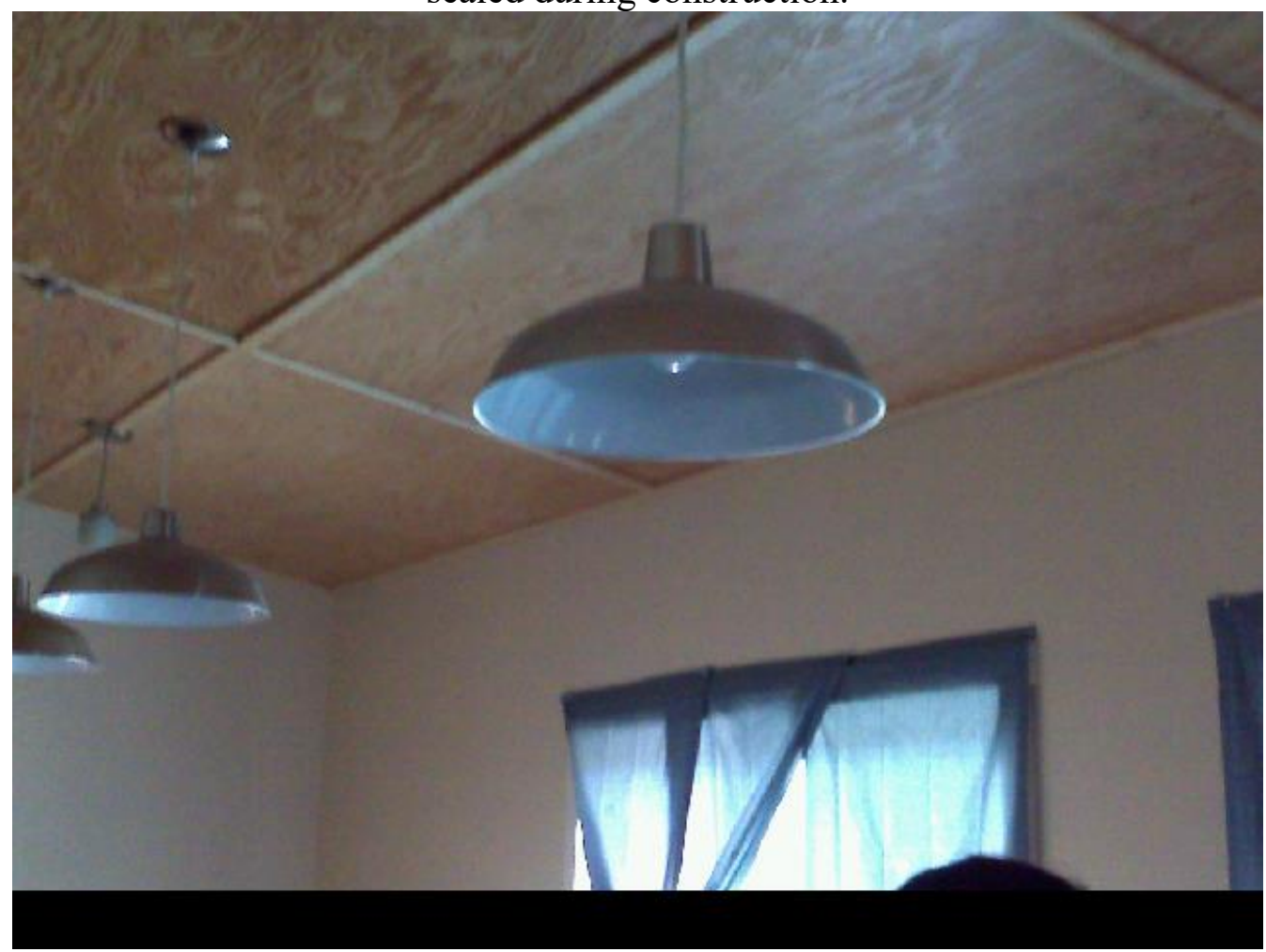

Kitchen ceiling. 


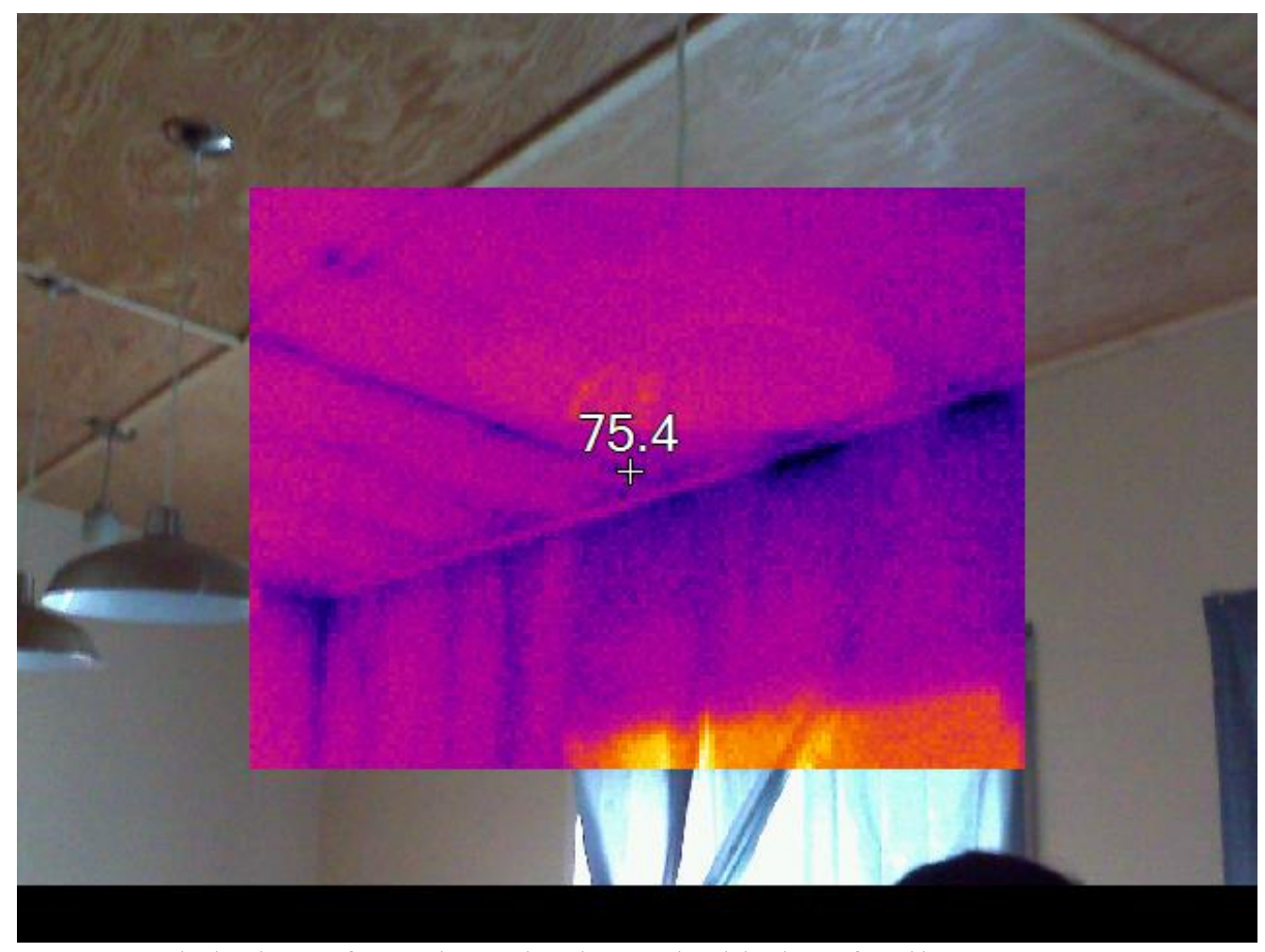

Air leakage from the attic above the kitchen family room area.

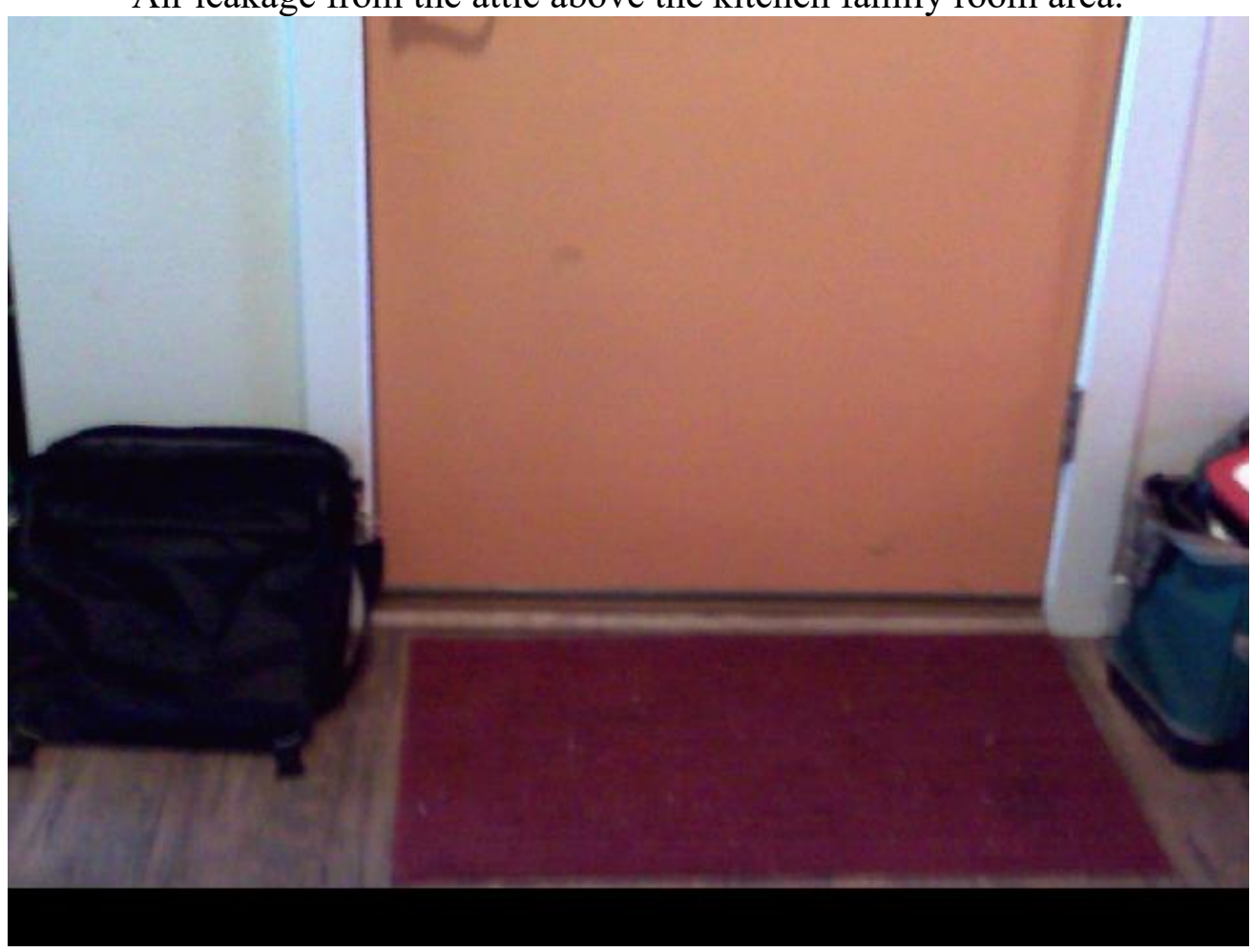

Front Door. 


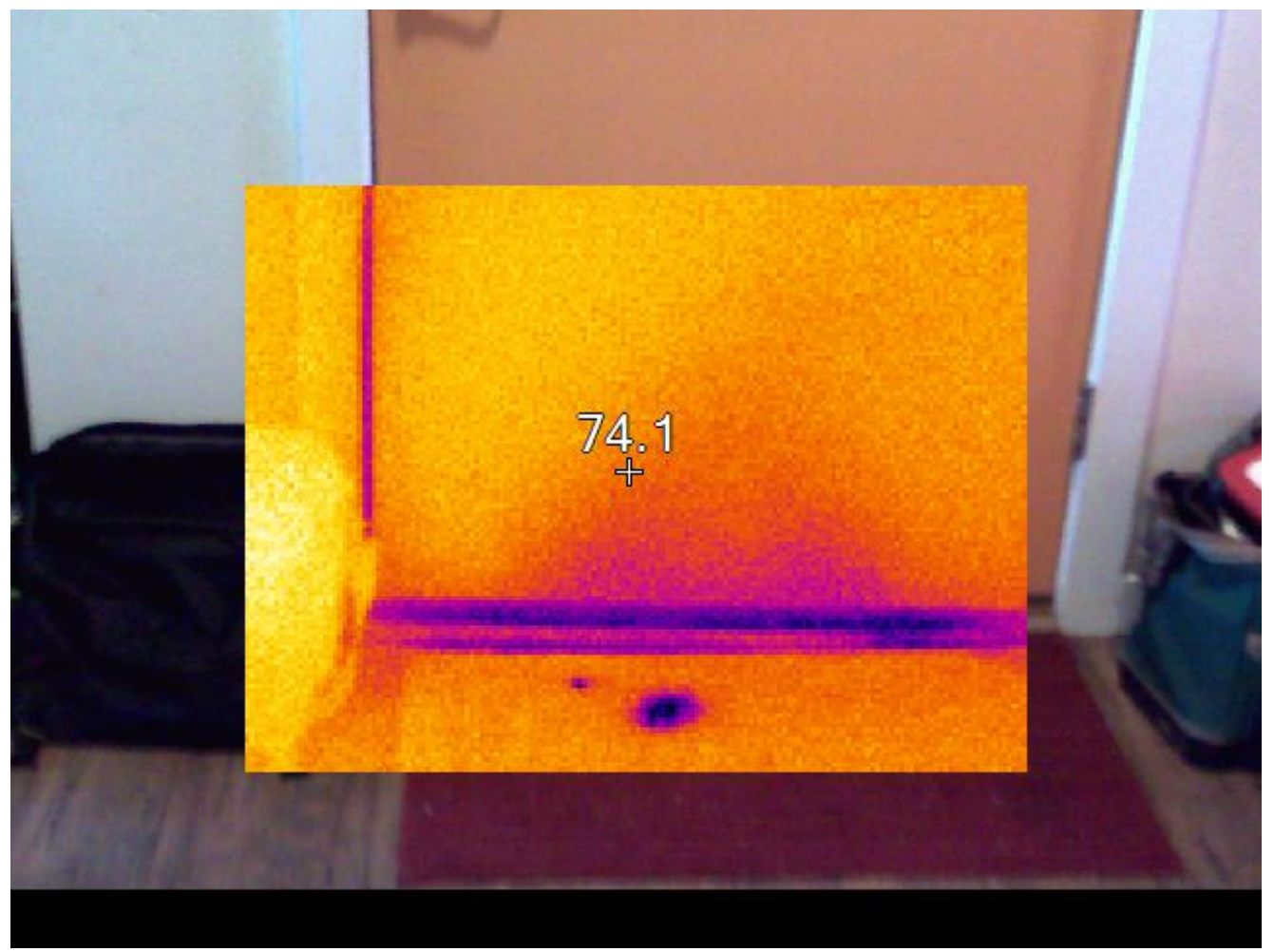

Air leakage at the door sweep. 